\title{
CONSEQUENCES OF SUPREME COURT DECISIONS UPHOLDING INDIVIDUAL CONSTITUTIONAL RIGHTS
}

\author{
Jesse H. Choper*
}

\section{TABLE OF CONTENTS}

INTRODUCTION $. . . \ldots \ldots \ldots \ldots \ldots \ldots \ldots \ldots \ldots \ldots \ldots, \quad 4$

I. Complexities of Measurement ................ 7

II. Some Illustrations Prior to $1935 \ldots \ldots \ldots \ldots \ldots \ldots . .12$

A. The Post-Civil War Period .................... 12

B. The "Lochner" Era ........................ 13

III. The Hughes, Stone, AND Vinson Courts ......... 14

A. Rights of the Accused ........................ 15

1. Coerced Confessions ........................ 15

2. Appointed Counsel ....................... 15

a. Federal prosecutions .................... 15

b. State prosecutions........................ 16

B. Free Speech: Labor Picketing .................. 17

C. Religious Freedom: Jehovah's Witnesses ........... 18

D. Company Towns........................... 19

E. Racial Discrimination ........................ 19

1. Voting ................................. 19

2. Housing ............................. 21

3. Education $\ldots \ldots \ldots \ldots \ldots \ldots \ldots \ldots \ldots \ldots \ldots, 22$

IV. The Warren Court........................... 25

A. Racial Separation .......................... 25

1. Segregation ........................... 25

2. Miscegenation......................... 28

* Dean and Professor of Law, University of California, Berkeley. B.S. 1957, Wilkes College; LL.B. 1960, University of Pennsylvania; D. Hu. Litt. 1967, Wilkes College. - Ed.

At one time or another, I have burdened about two-thirds of my colleagues at Boalt Hall (as well as at other departments at Berkeley) for counsel and criticism in respect to this work. I wish to express my appreciation to all of them for their valuable comments (and for their patience), to Professor Michael E. Smith for initially prodding my efforts, and to the following former students for their able research assistance: Donna J. Brorby, Class of 1977; Susan Feller, Class of 1980; Violet Elizabeth Grayson, Class of 1982; John T. Hightower, Class of 1983; Stevan C. Kalmon, Class of 1975; Esther Y. Kim, Class of 1983; Leonard J. Martiniak, Class of 1974; Alison S. Melnick, Class of 1983; John A. O'Malley, Class of 1981; Steven M. Quevedo, Class of 1985; David H. Rose, Class of 1983; Stephen B. Sadowsky, Class of 1979; Robert G. Seeds, Class of 1983; Robert J. Whalen, Class of 1978. 
B. Rights of the Accused .................. 30

1. Exclusionary Rule .................... 30

2. Equality for the Poor ................... 33

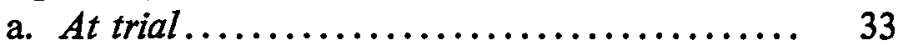

b. On appeal....................... 35

3. Line-ups ......................... 36

4. Jury Trial ....................... 39

5. Self-Incrimination................... 41

6. Cruel and Unusual Punishment.............. 42

7. Commitment of Mentally Ill.............. 44

8. Juveniles ........................ 46

9. Military Justice ..................... 55

10. In General ........................ 57

C. Free Expression and Association ............... 58

1. Censorship .......................... 58

2. Defamation ....................... 63

3. Loyalty-Security................... 66

4. Obscenity ............................ 68

5. Group Legal Services .................. 74

D. Religious Freedom: Public Schools ........... 77

1. Prayers ............................... 77

2. Evolution ........................... 79

E. Sexual Conduct: Contraception ............. 82

F. Right to Vote .......................... 85

1. Denials: In General................... 85

2. Poll Taxes ........................... 88

3. Dilution: Apportionment ............... 90

4. Ballot Restrictions..................... 95

G. Discrimination Against New Residents ........... 98

H. Debtors' Rights: Wage Garnishment ........... 102

I. Expatriation ........................ 104

V. The Burger Court $\ldots \ldots \ldots \ldots \ldots \ldots \ldots \ldots \ldots \ldots \ldots$

A. Rights of the Accused .................... 107

1. Search and Seizure.................... 107

a. Persons present during lawful search ........ 107

b. Arrest at suspect's home................ 109

2. Equality for the Poor ................... 112

a. Right to counsel ................... 112

i. Preliminary hearings............. 112

ii. Misdemeanor trials ............... 114

iii. Enhanced punishment ............. 116

b. Sentence ...................... 117 
3. Self-Representation .................... 119

4. Double Jeopardy ...................... 121

a. Collateral estoppel .................. 121

b. Insufficient evidence ................. 122

c. Successive state-municipal prosecutions ...... 123

5. Capital Punishment .................... 124

6. Prisoners ............................ 126

a. Disciplinary proceedings .............. 126

b. Good conduct credit ................... 130

7. Parole and Probation Revocation ............. 130

8. Juveniles ........................ 135

a. Burden of proof .................. 135

b. Reprosecution as adult ............... 136

B. Commitment of Mentally Ill ............... 138

1. Incompetency To Stand Trial ............... 138

2. Continued Involuntary Institutionalization ...... 142

C. Procedural Due Process ..................... 146

1. Denial of Welfare Benefits ................ 146

2. Divorce Filing Fees ................... 150

3. Denial of Child Custody.................. 152

4. Suspension from Public Schools ............. 153

5. Termination of Utility Service............. 157

6. Adjudication of Paternity ............... 158

D. Free Speech, Press and Association ........... 162

1. Commercial Advertising .................. 162

2. Patronage ........................... 169

3. Access to Criminal Trials ................. 172

4. Right of Reply Laws ................... 173

5. Compulsory Unionism .................... 175

E. Religious Freedom ........................ 179

1. Compulsory Education Laws............... 179

2. Financial Aid to Parochial Schools ............ 181

F. Sexual Conduct: Abortion ................ 183

G. Just Compensation ...................... 190

H. Equal Protection ....................... 194

1. Racial Separation ..................... 194

2. Aliens ............................ 197

3. Gender .............................. 199

4. Illegitimate Children .................... 203

I. Right To Vote.......................... 206

1. Fees for Filing in Primaries............... 206

2. Restrictions on Crossovers................ 208 
POSTSCRIPT $\ldots \ldots \ldots \ldots \ldots \ldots \ldots \ldots \ldots \ldots \ldots \ldots \ldots \ldots, 210$

\section{INTRODUCTION}

Preserving the constitutional rights of individuals against abridgment by popular majorities is probably the most frequently voiced and, in my judgment, is the most soundly based - justification for the Supreme Court's exercising the awesome power of judicial review. ${ }^{1}$ But to state this as a matter of theory falls far short of demonstrating that the Court's efforts in this regard have had truly meaningful impact.

Indeed, distinguished observers have contended during most periods of our history that reliance on the Court for the task of safeguarding personal liberties is misplaced. Henry Steele Commager complained in 1943 that the judicial record in the field of individual rights "is practically barren . . . as far as federal legislation is concerned." 2 Four years later John Frank, considering judicial review of state actions, observed that "for the most part, the civil rights limitations on the states have been a collection of magnificent trifles." 3 Even during the heyday of the Warren era, Robert Dahl concluded in 1967 that "it is doubtful that the fundamental conditions of liberty in this country have been altered by more than a hair's breadth"4 as a result of the judiciary's invalidation of congressional action, and he reiterated this view with but the slightest qualification in $1972 . .^{5}$ And in 1975 another commentator opined that overall "[t]he traditional concept of the Court as the champion of minority rights . . . is largely incorrect." 6

Moreover, whatever the usually more favorable conclusions concerning the Justices' endeavors during the relatively short period of the Warren Court, the product of its successor has regularly been found sorely wanting in its protection of personal freedoms. Thus, commenting on the. Burger Court's 1972-1973 efforts, Norman Dorsen, then general counsel of the American Civil Liberties Union, ob-

1. See generally J. Choper, Judicial Review and the National Political Process 60-70 (1980).

2. H. COMmager, Majority RULe AND Minority Rights 47 (1950).

3. Frank, Review and Basic Liberties, in SUPREME CourT AND SUPREME LAw 109, 139 (E. Cahn ed. 1954); see also Ulmer, Judicial Review as Political Behavior: A Temporary Check on Congress, 4 AD. SCI. Q. 426 (1959).

4. R. Dahl, PluRalist Democracy in the United States: Conflict and Consent 166 (1967).

5. R. Dahl, Democracy in the United States: Promise and Performance 203-04 (2d ed. 1972).

6. Funston, The Supreme Court and Critical Elections, 69 AM. PoL. Scr. Rev. 795, 809 (1975) (emphasis in original). 
served that "[a]n entire generation of young Americans has come of age accustomed to looking to the Supreme Court to protect individual rights," but that "the first full year of the Burger Court reveals quite distinctly that this period has ended." " Similarly, in the preface to his influential treatise, published in 1978, Laurence Tribe declared

that the course of the Burger Court, at least in its first years, will eventually be marked not as the end of an era of exaggerated activism on behalf of individuals and minorities, but as a sad period of often opposite activism, cloaked in the worn-out, if well-meant, disguise of judicial restraint. ${ }^{8}$

More harshly, in 1974, Leonard Levy complained that a majority of the Justices "vote for the rights of the criminally accused about as often as snarks are sighted alighting on the roof of the Supreme Court building." In 1978, Henry Steele Commager was reported to have "condemned the current Supreme Court for what he called a 'tragic' lack of protection of individual rights,"10 an expansion of his criticism of nearly thirty years earlier. And these pessimistic appraisals have continued unabated into the 1980 's. ${ }^{11}$

One must be hesitant to distill too precise a meaning from these many broadly phrased value judgments. ${ }^{12}$ There is considerable uncertainty as to the core emphasis of the criticism - whether it is that the number of decisions rendered in favor of individual rights has been too few; or that, regardless of how many such rulings the Justices have issued, the number of people involved has been insignificant; or that, no matter how many people have been affected, the actual consequences for them have been relatively trivial; or that, in any event, the Court's total impact on conditions of freedom in the nation has been minimal at best. Further, the extent to which the reprovers of the Burger Court are merely comparing its output to that of its immediate predecessor rather than making an absolute evaluation is somewhat unclear, although the tone of the disapproval strongly implies the latter intent.

These ambiguities notwithstanding, it is fair to infer a common message from the critical assessments: the Court's holdings in behalf.

7. Dorsen, The Court of Some Resort, 1 Civ. Lib. REv. 82, 82 (1974).

8. L. TRIBE, AMERICAN CONSTITUTIONAL LAW v (1978).

9. L. LEVY, AGAINST THE LAW 439 (1974).

10. Historian Attacks High Court, San Francisco Chron., Oct 18, 1978, at 36, col. 1.

11. See, e.g., Court Swings to the Right, Gives Reagan Major Victories, 42 CONG. Q. WEEKLY REP. 1709 (1984).

12. For example, Commager's opinion of the Court's usually substantial deference to acts of Congress as of 1950 must surely be appraised differently from his much more far-reaching conclusion nearly three decades later about the Justices' record in reviewing actions taken at all levels of government. 
of personal liberties have not been very important. In response, this Article seeks to examine the record - at considerable length and in some depth ${ }^{13}$ - by reviewing a large number of cases from shortly after the Civil War through the 1980-1981 Term in which the Court has held government action unconstitutional on the ground that it abridges individual rights (as distinguished from violating the constitutional precepts of federalism or separation of powers). ${ }^{14}$ The purpose of this inquiry is not to ask whether the Justices' rulings were substantively "right" or "wrong" as a matter of doctrine or policy. (Although I approve of most of the results in these terms, I do not agree with them all.) Nor does it intend to answer the imponderable question (to be discussed somewhat below ${ }^{15}$ ) of whether the effects of the Court's decisions in favor of personal liberties have been "good" or "bad" for society overall (as distinguished from their particular beneficiaries).

Rather, the thrust of this Article is to attempt to ascertain just what differences the Court's judgments upholding individual constitutional rights have made for those who fall within the ambit of their protection. It seeks to address such questions as: What were the conditions that existed before the Court's ruling? How many people were subject to the regime that was invalidated by the Justices? Was the Court's mandate successfully implemented? What were the consequences for those affected? At a subjective level, were the repercussions perceived as salutary by those (or at least most of those) who were the beneficiaries of the judicial decrees? At a more objective level - although the line between the subjective and objective on a matter like this is quite ethereal - were those effects understood by others as working to the advantage of the recipients, apart from their impact on society as a whole? Some of the "case studies" - and I use the term with trepidation ${ }^{16}$ - set forth below attempt to respond to most or all of these issues, while others (because of the nature of their subject) are more confined.

Many of the decisions reviewed (such as those concerning racial, religious, and political minorities and people accused of crimes) deal with personal liberties or civil rights as traditionally perceived. Other

13. The research has been done irregularly since 1974 and was orginally intended for J. CHOPER, supra note 1. Since I felt that comprehensive treatment there would have unduly lengthened the book and diverted readers from its main themes, see id. at 91 \& n.150 at 429 , only some of the results - which are also contained in this Article - were included therein. See id. at 83-122. I have attempted to bring all the research up to date, but continually unfolding events on so large and diverse a subject have undoubtedly frustrated that ideal.

14. See J. CHOPER, supra note 1, at 1-2.

15. See text following note 27 infra.

16. See text following note 31 infra. 
rulings (such as those involving property interests and commercial advertising) are also included because, like the more conventional examples, they, too, fall within the designated category of constitutional decisions that limit all government power - that of the three federal branches and of the states — vis-à-vis the individual. ${ }^{17}$

\section{Complexities of Measurement}

Before proceeding to inspect the data, several important qualifications concerning the breadth and significance of this undertaking must be noted. First, any attempt to measure the societal effects of judicial holdings - which this Article seeks to do - is an enormously complicated task which must necessarily be incomplete and open-ended. ${ }^{18}$ Perhaps the greatest difficulty - addressed in context at several points in the substance of this Article ${ }^{19}$ - is that the repercussions of all government actions ramify indefinitely and interrelate with other phenomena, both public and private, many of which simply cannot be quantified and indeed often cannot even be identified. Thus,

the decisions of the Supreme Court are part of a general milieu in which later events take place and part of a set of multiple causes of such events.

If several factors are operating in the same direction, how does one "separate out" the impact the Court's decision has by comparison with other elements of the situation?20

When libertarian reforms do occur in the aftermath of pronouncements by the Justices requiring them, how can it be confidently said that such advances would not have come about in any event, if not as quickly then at least eventually? The Court's ruling may have done no more than reflect, or perhaps anticipate, or at best reinforce, what would have ultimately happened anyway. "Even the most careful study cannot establish whether alleged changes were not merely coincidentally but actually consequentially related."21 Indeed, there is good reason to believe that, at least in some instances, laws held invalid by the Supreme Court would have soon fallen at the hands of the political process even without judicial intervention. ${ }^{22}$ On the other

17. See J. CHOPER, supra note 1 , at 1-2.

18. There is a voluminous social science literature on the subject. See, e.g., R. MERTON, Social TheORY AND Social Structure (1968); S. WASBy, The IMPACT OF THE UNITED STATES SUPREME COURT 32-42 (1970).

19. See, e.g., text at notes $490,1386-88,1507-10$ infra.

20. S. WASBY, supra note 18 , at 32 .

21. S. Krislov, The Supreme Court and Political Freedom 166 (1968). See generally Feeley, Approaches to the Study of Court Impact, in 2 Schools \& THE CoURTs 1, 4-7 (M. Feeley, P. Piele, E. Hollingsworth \& W. Clune eds. 1979).

22. For example, in Pierce v. Society of Sisters, 268 U.S. 510 (1925), the Court rejected a 1922 Oregon statute that forbade children from attending private elementary and secondary 
hand, the extent to which the symbolic impact of a judicial ruling or a series of related decisions acts as a direct or indirect catalytic force is generally incapable of scientific measurement, ${ }^{23}$ as will also be noted in specific situations herein. ${ }^{24}$

Second, even if we assume that nothing other than a Supreme Court decision upholding individual rights will result in their being secured, there is no assurance that all constitutional pronouncements of the Justices will be complied with in practice. One of the complex set of variables that contribute to this variation in compliance ${ }^{25}$ is the effort necessary to effectuate the ruling. Some decisions in favor of personal liberties are relatively "self-enforcing," such as those establishing certain rights of the accused. For example, a person charged with a crime and faced with a prison sentence has every incentive to assert his constitutional right to be represented by a lawyer. Trial judges ordinarily have a comparable motivation to respect the claim, whether or not they are in sympathy with it, because they recognize that their failure to do so will result in reversal of the conviction. On the other hand, effectuation of some judicial rulings in behalf of individual rights against recalcitrant public officials may demand much greater commitment and fortitude on the part of their beneficiaries. This may be exemplified by the school prayer controversies. If a public school wishes to continue voluntary Bible-reading programs despite

schools. The legislation was enacted in a post-World War I "outburst of patriotism and nationalism," R. Mclaughlin, A History of State Legislation Affecting Private Elemen. TARY AND SECONDARY SchoOLS IN THE UNITED STATES, 1870-1945, at 84 (1946), but was specifically "inspired by the Ku Klux Klan and directed primarily against the parochial schools of the Roman Catholic Church," The March of Events, 50 THE WORLD's WORK 243 (1925); R. MCLAUghis, supra, at 106-07. Catholic leaders perceived the law as "the first movement in an attack which will find Catholics in the United States 'suffering from disabilities with which the Catholics of England were afflicted three generations ago." Oregon's Outlawing of Church Schools, LITERARY Dig., Jan. 6, 1923, at 34. But even before the Justices' ruling, efforts to promulgate similar rules in Michigan and Washington were resoundingly defeated by the electorate. Klan Victories and Defeats, LITERARY Dig., Nov. 22, 1924, at 16; R. McLAughlin, supra, at 111-13.

Similarly, in McDaniel v. Paty, 435 U.S 618 (1978), the Court invalidated Tennessee's rule forbidding members of the clergy from being legislators. Although at one time in our early history, 13 states had such disqualifications, 1 A. STOKES, CHURCH AND STATE IN THE UNITED STATES 622 (1950), by the end of the nineteenth century, 11 had voluntarily abandoned their exclusion, 435 U.S. at 625 , and by mid-twentieth century, the remaining two laws appeared to be no more than historical relics. Thus, when a federal district court held Maryland's prohibition unconstitutional in 1974, Kirkley v. Maryland, 381 F. Supp. 327 (D. Md. 1974), in the only other reported case on the question, the challenging minister had been permitted to file as a candidate and the state "for all intents and purposes, admitted the unconstitutionality of the provision." 381 F. Supp. at 329. And, in McDaniel, the state did not participate in the litigation, the minister's political opponent having sued to strike his name from the ballot. 435 U.S. at 621 .

23. See generally S. Scheingold, The Politics of Rights (1974).

24. See, e.g., text at notes $125-32$ (racial equality), 345 (children's rights) \& 367 (rights of the accused) infra.

25. For fuller discussion, see J. CHOPER, supra note 1, at 129-70. 
the Justices' proscription of the practice, vindication of the constitutional right requires objecting parents and students to initiate litigation. They must risk the social obloquy that is likely to result from their preventing the majority from engaging in a much desired activity from which it is already willing to permit dissenters to be excused. ${ }^{26}$

Third, even if we assume literal compliance with the Court's mandates, the degree to which they are truly meaningful (or beneficial) to the individuals affected - measured either subjectively or objectively - varies considerably. For example, there is little doubt about the significance for prisoners on death row of the consequences - desired, or sometimes undesired - of a judicial decision invalidating capital punishment. But even if counsel is appointed at state expense for all indigent criminal defendants because of a ruling by the Justices which, in itself, must be scored as a substantial judicially produced success - this does not insure that the quality of the representation afforded will be of any value to many of the accused or, even if only very talented lawyers are assigned, that their participation will make any real difference in the verdict of most cases. ${ }^{27}$

Fourth, even if we assume that the Court's decisions upholding

26. See Choper, Comments, 23 J. Legal Educ. 143, 145-46 (1970).

27. This same problem may be illustrated by Miranda v. Arizona, 384 U.S. 436 (1966). It appears that prior to Miranda, the Federal Bureau of Investigation was the only civilian police force in the United States that afforded the substance of the Miranda warnings for custodial interrogation. See 384 U.S. at 483-90 (majority opinion), 384 U.S. at 521 (Harlan, J., dissenting). While some of the empirical studies immediately following the Court's promulgation of its new rules disclosed pockets of significant resistance by law enforcement officials, others revealed prompt and full compliance. Compare N. MILNER, The COURT AND LOCAL LAW ENForCEMENT 229 (1971) (four Wisconsin cities); Medalie, Zeitz \& Alexander, Custodial Police Interrogation in Our Nation's Capital: The Attempt to Implement Miranda, 66 Mrch. L. REv. 1347, 1365-66 (1968) (Washington, D.C.) [hereinafter cited as Medalie]; Note, Interrogations in New Haven: The Impact of Miranda, 76 YALE L.J. 1519, 1614 (1967) (New Haven), with Seeburger \& Wettick, Miranda in Pittsburgh - A Statistical Study, 29 U. PrTr. L. REv. 1, 8 (1967) (Pittsburgh). However, substantial acceptance was rapidly achieved and adherence improved immeasurably through a brief transitional period. See N. MILNER, supra, at 211; Medalie, supra, at 1362; Note, supra, at 1640 . In a subsequent investigation, public defenders in a rural area of Massachusetts reported that "the police were assisting in enforcement of the spirit of Miranda by making it easier for those in custody to contact lawyers." S. WASBY, SMALL TOWN POLICE AND THE SUPREME COURT 117 (1976). By 1979, a questionnaire survey of the chief prosecuting attorneys in the nation's 300 largest counties showed that only $17 \%$ of the respondents disagreed with the Justices' edict (and only 4\% disagreed "very much"). Gruhl \& Spohn, The Supreme Court's Post-Miranda Rulings, 3 LAw \& PoLY. Q. 29, 35 (1981). In the absence of any recent on-site studies suggesting the contrary, it is fair to conclude that the Miranda warnings are now given in a very high percentage of instances, a view confirmed by a litigation record indicating comparatively few deviations from the core of the Miranda holding, cf. Gruhl \& Spohn, supra, at 43, and a relatively generous application of its principle to unresolved issues by the state courts, see Romans, The Role of State Supreme Courts in Judicial Policy-Making: Escobedo, Miranda and the Use of Judicial Impact Analysis, 27 W. PoL. Q. 27 (1974), and even on occasion by the Burger Court, see Choper, The Burger Court: Misperceptions Regarding Judicial Restraint and Insensitivity to Individual Rights, 30 SYRACuse L. REV. 767, 775-77 (1979). Cf. Berkemer v. McCarty, 104 S. Ct. 3138 (1984) (holding that alleged drunk driver's statements at the station house were inadmissible because he was in custody and had not been read his rights). But see 
individual rights do in fact produce important benefits, it must be recognized that virtually all such gains for some persons may simultaneously retard the welfare of others. This may be most dramatically illustrated by the inherent collision of interests between pregnant women and unborn fetuses in the abortion setting, a conflict that is impossible to reconcile because, inter alia, the data as to exactly how those concerned would fare in all relevant respects if the issue were resolved otherwise are either nonexistent or unobtainable or, even more importantly, there is simply no acceptable scale on which to weigh the antagonistic values. Most other constitutional controversies raise this problem as well - whether they involve the rights of those accused of crime versus the rights of law-abiding citizens not to be deprived of their life or property, or the competing goals of different groups in respect to such issues as racial segregation, reapportionment, affirmative action, or just compensation for takings (to mention but a few). This aspect of the problem is beyond the scope of this Article. Indeed, even when there is consensus on certain general propositions concerning the commonweal - such as the view that robust debate on public issues will enhance the successful operation of the political process - there is no assurance that granting constitutional protection to defamatory criticism of political candidates will make a positive or

New York v. Quarles, 104 S. Ct. 2626 (1984) (public safety exception to the Miranda warnings rule).

This result, in itself, should be recognized as an important achievement by the judiciary, especially in terms of the significant (albeit intangible) value of government respect for individual dignity. At the next level of inquiry, however, further problems arise. Empirical studies have disclosed that a substantial number of suspects fail to understand the content of the warnings they receive. See Leiken, Police Interrogation in Colorado: The Implementation of Miranda, 47 DEN. L.J. 1, 14-16 (1970); Medalie, supra, at 1374 (15\% to 24\%); see also Faculty Note, $A$ Postscript to the Miranda Project: Interrogation of Draft Protestors, 77 YALE L.J. 300, 313-14 (1967). This incomprehension, in turn, has been shown to influence many to waive the proffered rights to silence and counsel, $c f$. N. MiLNER, supra, at 211 , a process not uncommonly abetted by subtle (and sometimes heavy-handed) police suasion. See Leiken, supra, at 22, 27; Faculty Note, supra, at 308-09; Note, supra, at 1545-46. Thus, although many of the studies were conducted soon after the Supreme Court's decision and before the longer run educative effect that the Justices' pronouncements may have on the citizenry's awareness of their rights at the stationhouse, see Note, supra, at 1615 , the data strongly suggest that giving the Miranda warnings has no significant impact on suspects' decisions to talk to police interrogators. See Leiken, supra, at 18; Medalie, supra, at 1372, 1376-79; Note, supra, at 1563-64, 1571, 1578.

The statistics appear to be otherwise, however, in respect to the assistance of a lawyer. The District of Columbia study showed that while almost two-thirds of arrestees who were informed of their right to counsel requested assistance, more than three-fourths of those who were not so advised failed to exercise the right. Medalie, supra, at 1371-72. But again, the ultimate benefit of the fulfillment of this right for most persons potentially subject to police questioning is seriously clouded because of their tendency to cooperate in any event, see supra, and because of the very limited utility of custodial interrogation in most cases - various empirical projects finding it to be usually unnecessary and often unsuccessful when really needed. See Reiss \& Black, Interrogation and the Criminal Process, 374 ANNALs 47, $55-56$ (1967); Note, supra, at 1549, 1585 (table 20), 1590 (table 21), 1592 (table F-8), app. I, at 1639-43 . 
negative contribution to the ideal..$^{28}$

Fifth, even if we were to assume - after measuring all the gains and losses - that the Court's holdings of unconstitutionality have on balance effectively negated substantial political abridgments of personal liberty, history reveals that other decisions of the Justices which refused to hold unconstitutional claimed violations of individual rights - have exacerbated the infringement of the interests for which protection was sought. For, at least in some instances, it can be expected that the Court's validation of the position of a political majority may prompt it to work its will more broadly. 29

Furthermore, as recently illustrated by the activities of the Moral Majority, continued vigorous judicial enforcement of personal liberties may stimulate powerful reaction among the populace and officialdom that seeks not simply to reverse direction but to move things back from the point where the trend began. On the other hand, the existence of judicial review and the mere possibility that the Court will invalidate a governmental practice may have caused political officials and institutions to adjust their behavior and refrain from impinging on individual interests, perhaps to an even greater extent than the Justices would have demanded. ${ }^{30}$

At least as yet, there appears to be no way to conduct a scientifi-

28. See Wellington, On Freedom of Expression, 88 YALE L.J. 1105, 1113-16 (1979).

29. For example, after the Court reluctantly upheld the compulsory flag salute rule in Minersville School District v. Gobitis, 310 U.S. 586 (1940), "the West Virginia legislature enacted a comparable statute for the state as a whole, and other states quickly joined the repressive bandwagon." Wright, The Role of the Supreme Court in a Democratic Society - Judicial Activism or Restraint?, 54 CoRNell L. Rev. 1, 7-8 (1968). Within one year of Ginsberg v. New York, 390 U.S. 629 (1968), in which the Court ruled that states have broad regulatory power over distribution of sexually related materials to minors, "at least twenty city councils across the country were found to have passed statutes like that validated." S. WASBY, supra note 18, at 142 . More speculatively, and subject to the same imponderable factors discussed above, it has been observed that as a result of the Court's sanctioning of the separate-but-equal precept in Plessy v. Ferguson, 163 U.S. 537 (1890), "racial segregation came to dominate virtually all areas of Southern life," D. Berman, It Is So Ordered: The Supreme Court Rules on School Desegregation 5 (1966), and the doctrine became "the linchpin of Jim Crow jurisprudence in America." Levy, Introduction, in THE SUPREME COURT UNDER EARL WARREN 3, 21 (L. Levy ed. 1972).

For the extent to which some states courts, interpreting their own constitutions, may halt the contagion within their borders, see text at notes 1610-11 infra.

30. "[T] $]$ he Post Office often mooted cases involving restrictions on receipt of mail when an irate individual threatened to go to court, in order to avoid a court decision on its practices of holding mail." S. WASBY, supra note 18, at 37. Congress's rejection of legislation in 1940 to deport Harry Bridges by name "was heavily, though not exclusively, influenced" by fears that the Court would find this to be a bill of attainder. Frank, supra note 3, at 126. Similar concerns about judicial invalidation caused proposed provisions of the McCarran Act of 1950 (directly outlawing the Communist Party) and the Smith Act of 1940 (prohibiting civilian military organizations) to be stricken in committee. Id.

Indeed, it may be that the host of strenuous constitutional objections to the numerous recent proposals in Congress to limit the jurisdiction of the federal courts have ultimately tipped the balance against them. 
cally controlled inquiry to determine whether, all things considered, the state of freedom within the nation is "better" than it would have been without the Justices' involvement, ${ }^{31}$ and this Article makes no effort to do so. But that all of the five sets of imponderables sketched above may be incapable of systematic resolution should not deter us from determining what is and can be known about some things.

The empirical studies that have been specifically directed to the impact of the Court's efforts in behalf of personal liberties are relatively few in number and methodologically uneven in thoroughness and quality. Some of the material presented below is drawn from these studies. But, in the main, the data for this Article have been obtained from disparate, already published sources that have assembled evidence for entirely different purposes. As is true of most of the more detailed empirical surveys that have been made of specific problems, some of the following "case studies" are based on more complete statistics and information than others and some are grounded more in opinion than on actual observation and hard facts. Indeed, some are either so brief or inconclusive that I have included them only because of their possible cumulative value as part of the larger enterprise.

I want to make it clear (1) that this work was undertaken to show that the Court's decisions upholding personal rights secured by the Constitution - whether "right" or "wrong" doctrinally, or "good" or "bad" for society as a whole - have nonetheless enhanced the liberties of many individuals and produced substantial consequences, and (2) that, contrary to conventional social science precepts, I have occasionally resolved certain doubts to make that point. Therefore, the effort may, at least in part, be fairly characterized as being not only methodologically deficient but tendentious as well. Nonetheless, the evidence, especially when viewed collectively, plainly suggests that the Justices' rulings in favor of individual rights have, at a minimum, unplugged serious blocks and made important contributions to social change meaningfully affecting the lives of many people. It therefore clearly points in a direction opposite to that implied by the broadly phrased pessimistic judgments expressed by the eminent critics above.

II. Some Illustrations Prior to 1935

\section{A. The Post-Civil War Period}

As early as 1867, the Court's invalidation of post-Civil War federal and state loyalty oaths, which had prevented Confederate "sympathiz-

31. See J. Choper, supra note 1, at 65-66. 
ers" from acting as lawyers or ministers, ${ }^{32}$ meaningfully furthered the cause of individual liberty. Although national oaths for federal office, employment, and jury duty persisted, within months of the Justices' rulings, "ex-rebel attorneys could practice in all the courts of the nation." 33 "The boon presented by the Court to dispossessed lawyers in the Garland case, was of inestimable benefit to Southerners of the legal fraternity . . . . [I]t made possible the financial recuperation of great numbers of former Confederates . . . ."34 Futhermore, several state courts (although not all) followed the Garland and Cummings mandate to abrogate similar impediments to voting and teaching, thus freeing additional Southerners from the loyalty oaths' political and economic shackles. ${ }^{35}$

\section{B. The "Lochner" Era}

The decisions of the nineteenth and early twentieth centuries, in which a majority of the Justices acted under several clauses of the Constitution to preserve economic interests, also spoke in behalf of personal rights. Although these rulings benefited persons of property and affluent minorities rather than unpopular individuals and downtrodden groups and, hence, may be disapproved by many under contemporary libertarian standards, the fact is that they served the ideal of limited democracy and secured interests that were originally regarded as fundamental. ${ }^{36}$ Because the state of empirical methodology was nascent during the first third of this century when the Court rejected governmental attempts to regulate various economic relationships on nearly two hundred occasions," "[t] estimating reliably the restraining effect of this cloud of negativism on state legislators and congressmen who might otherwise have made haste more speedily along the road to the welfare state." And it may be "highly questionable" that this course of decisions was "a major factor in determining the drift of American economic policy during

32. Cummings v. Missouri, 71 U.S. 277 (1866); Ex parte Garland, 71 U.S. 333 (1866).

33. H. HYMAN, ERA OF THE OATH, 115 (1954) (footnote omitted).

34. Russ, The Lawyer's Test Oath During Reconstruction, 10 Miss. L.J. 154, 165 (1938).

35. H. HYMAN, supra note 33, at 116-18.

36. It is well known that one of Alexander Hamilton's primary concerns respecting judicial protection of personal liberties was that majority tyranny in state legislatures would subvert the vested rights of the creditor class. See Dietze, Hamilton's Federalist - Treatise for Free Government, 42 CoRnell L.Q. 307, 310, 511 n.232 (1957). And, as viewed by Henry Maine, the Court's very early interpretations of the contracts clause proved to be "the bulwark of American individualism against democratic impatience and Socialist fantasy." H. MAINE, POPULAR GovERNMENT 248 (1886).

37. See generally W. LockHart, Y. KAMISAR \& J. ChOPER, CONSTITUTIONAL LAw: CASES - COMMENTS - Questions 433-41 (5th ed. 1980). 
this period." Nonetheless, Robert McCloskey found "no doubt" that "the pace of social change was moderated"; that "a respectable number of 'excesses' were prevented"; that "a respectable amount of money was saved for the businessman"; and - underlining this Article's attempt to avoid value judgments as to consequences - that "a good many laborers were left a little hungrier than they might have been if the Court had not been there to defend economic liberty."38

\section{The Hughes, Stone, ANd Vinson Courts}

Even in the period before the advent of the Warren Court, a host of decisions overruled government action that prejudiced racial, religious, and political minorities and rejected federal and state practices that disregarded critical rights of the accused. Again, rigorous empirical data measuring the effect of the Court's civil liberties rulings during the quarter-century stewardship of Chief Justices Hughes, Stone, and Vinson is unavailable. Some of the specific results - such as forbidding Congress to withhold salaries of named federal employees whom it found to be "subversive," 39 prohibiting municipal officials from denying speaking permits in censorial fashion, ${ }^{40}$ restricting judges from too easily holding critics of the judiciary in contempt, ${ }^{41}$ barring conviction of controversial public advocates on too sweeping charges, ${ }^{42}$ and protecting activities of persons with sincerely held religious beliefs no matter how aberrant or unbelievable $e^{43}$ - may have had no greater immediate force than the vindication of the personal constitutional rights of the particular litigants involved. But this consequence in itself is by no means unimportant, wholly apart from the possible deterrence of other repressive state action. ${ }^{44}$ In addition, there is sundry evidence - some factual, some inferential - corroborating the broader effectiveness of a number of other decisions that may be gleaned from scattered sources.

38. R. MCCloskey, The AMERICAN SUPREME CoURT 151 (1960).

39. United States v. Lovett, 328 U.S. 303 (1946).

40. Kunz v. New York, 340 U.S. 290 (1951); Saia v. New York, 334 U.S. 558 (1948);

Thomas v. Collins, 323 U.S. 516 (1945).

41. Craig v. Harney, 331 U.S. 367 (1947); Pennekamp v. Florida, 328 U.S. 331 (1946);

Bridges v. California, 314 U.S. 252 (1941).

42. Terminiello v. Chicago, 337 U.S. 1 (1949).

43. United States v. Ballard, 322 U.S. 78 (1944).

44. See note 30 supra. 


\section{A. Rights of the Accused \\ 1. Coerced Confessions.}

In 1936, five years after the Wickersham Commission disclosed that police use of "physical brutality, or other forms of cruelty, to obtain involuntary confessions or admissions" was "widespread" in the United States, ${ }^{45}$ the Court for the first time held that state convictions based on such confessions violated due process. ${ }^{46}$ No responsible person would contend that Brown v. Mississippi and its progeny have resulted in the complete eradication of all such crude conduct by law enforcement officers. ${ }^{47}$ And it may well be that the Justices' unanimous and consistent condemnation of bodily violence and explicit intimidation to obtain confessions has simply produced a shift in police tactics to more subtle techniques. Nonetheless, as reported by the Civil Rights Commission in 1961, "it is noteworthy that, with two exceptions [one concerning the use of a stomach pump ${ }^{48}$ and the other actually occurring before the Brown denunciation of the practice had time to be absorbed at the grass roots ${ }^{49}$ ] all Supreme Court confession cases since 1942 have involved psychological coercion alone."so And, in a more recent survey of prosecutors, defense attorneys, police magistrates, and trial judges, "it was generally agreed that [the Court's] decisions were instrumental in directing critical public attention to the more extreme forms of 'third degree' methods of interrogation, long practiced but previously taken for granted in this country." 51

\section{Appointed Counsel}

a. Federal prosecutions. Prior to 1938, it was "common practice" in the federal district courts not to assign counsel to indigent criminal defendants who wished to plead guilty; and, even when the accused asserted his innocence and went to trial, "some district courts did not appoint counsel for a defendant who appeared without an attorney, unless the defendant affirmatively and expressly requested that a law-

45. National Commission on LAw ObSERVANCE aNd ENFORCEMENT, Report on LAWLESSNESS IN LAW ENFORCEMENT, No. 11, at 4 (1931).

46. Brown v. Mississippi, 297 U.S. 278 (1936). In Bram v. United States, 168 U.S. 532 (1897), the Court held that the fifth amendment privilege against self-incrimination barred the use of involuntary confessions in federal courts.

47. See Beecher v. Alabama, 389 U.S. 35 (1967); United States v. Brown, 557 F.2d 541 (6th Cir. 1977) (allegations of police brutality).

48. Rochin v. California, 342 U.S. 165 (1952) (actually not a confession case but one involving a search for tangible evidence).

49. Reck v. Pate, 367 U.S. 433 (1961) (confession obtained a month after Brown decision).

50. U.S. COMmN. ON Civil RIGHTS, Book 5: Justice 17 (1961) (footnotes omitted).

51. O. Stephens, The Supreme Court and Confessions of Guilt 15 (1973). 
yer be designated to represent him."52 Both of these conditions were remedied for all federal criminal prosecutions by Johnson v. Zerbst ${ }^{53}$ and Walker v. Johnston ${ }^{54}$ in which the Court required counsel to be assigned to all indigent federal defendants who plead guilty or go to trial unless this sixth amendment right is intelligently and competently waived. 55

The significance of these safeguards for the accused, both quantitatively and qualitatively, is especially obvious for those indigent defendants who go to trial in federal court where criminal cases tend to be more complex than in the state systems. Quantitatively, in 1977, for example, more than eighty percent of the 53,000 federal criminal defendants were represented by appointed counsel.56 Qualitatively, attorney representation is especially important in a system in which a large number of cases are plea bargained ${ }^{57}$ because unrepresented defendants are seriously disadvantaged in that setting because of their lack of knowledge of the history and details of the negotiating and sentencing process in their judicial districts and of the practice of informal discovery that is utilized routinely by prosecutors and defense lawyers. 58

b. State prosecutions. In 1942, when the Court decided Betts $v$. Brady, ${ }^{59}$ the laws of Maryland and Texas flatly forbade the appointment of counsel for indigent criminal defendants in noncapital cases and dicta by the highest courts in Alabama and Mississippi strongly suggested that the same situation existed there; in nine additional states, the matter was unclear. ${ }^{60}$ Whatever the deficiencies of the Betts doctrine, at a minimum it did assure that a greater number of poor

52. Holtzoff, The Right of Counsel under the Sixth Amendment, 20 N.Y.U. L.Q. REv. 1, 8 (1944).

53. 304 U.S. 458 (1938).

54. 312 U.S. 275 (1941).

55. In 1945, the Federal Rules of Criminal Procedure codified this mandate and further stipulated that defendants be specifically advised of their right to the assistance of a lawyer. FED. R. CRIM. P. 44(a).

56. National Criminal Justice Information and Statistics Service, Law Enforcement Assistance Administration, U.S. Dept. of Justice, Sourcebook of Criminal Justice Statistics 72 (1979) $(43,178$ defendants represented by appointed counsel); National Criminal Justice Information and Statistics Service, Law Enforcement Assistance Administration, U.S. Dept. of Justice, Sourcebook of Criminal Justice Statistics 458 (1982) (total of 53,188 criminal defendants).

57. Approximately " 90 percent of all felony criminal convictions are the result of guilty pleas and ... the vast majority of these are the result of some form of plea-bargain." Rossman, McDonald \& Cramer, Some Patterns and Determinants of Plea Bargaining Decisions, in PLEA BARGaining 77 (W. McDonald \& J. Cramer eds. 1980). (1975).

58. Alschuler, The Defense Attorney's Role in Plea Bargaining, 84 YALE L.J. 1179, 1206-314

59. 316 U.S. 455 (1942).

60. 316 U.S. app., at 480 . 
persons charged with serious crimes in at least some of these thirteen states would be afforded a lawyer. ${ }^{61}$ In addition, over the succeeding two decades, the number of states making assignment of counsel mandatory in all felony cases if requested by the defendant increased from thirty-five to forty-five. ${ }^{62}$ Although there is no way to prove that the Court's ruling was the cause, it is wholly reasonable to infer that it was a substantial contributing factor.

\section{B. Free Speech: Labor Picketing}

In the last few years of the 1930's, a number of states and municipalities, responding to toughened antilabor sentiments, adopted a series of new laws against peaceful picketing and other forms of advertisement and communication in respect to labor controversies. The adverse impact of these laws on the labor movement was markedly reduced by the Court's holdings in Thornhill v. Alabama, ${ }^{63} \mathrm{Carl}$ son v. California, ${ }^{64}$ and $A F L$ v. Swing, ${ }^{65}$ which brought peaceful picketing under the protective umbrella of the first amendment and limited employers' ability to enjoin such activity. Whether these judicial pronouncements really constituted the "Magna Charta of Labor" (as they were often heralded at the time) or whether they were "of even greater value than the enactment by legislatures of state NorrisLaGuardia acts"66 (as the counsel to the American Federation of Labor then believed) is highly speculative. We do know that the Court hastened to qualify the broadest reaches of the newly articulated doctrines ${ }^{67}$ and that subsequent judicial development proceeded under the head of federal preemption rather than free speech. ${ }^{68}$ However, the fact remains that many state and lower federal courts followed the

61. A survey of 139 reported state court decisions applying the Betts "special circumstances" rule as of 1962 revealed that counsel was ordered in only 11 of the cases although a number of others appeared clearly to qualify. Brief for American Civil Liberties Union at 8-11, 50 (app. III), Gideon v. Wainwright, 372 U.S. 335 (1963). No systematic study, however, was made of the number of trial court appointments of counsel in those states that did not require automatic assignment in all felony prosecutions.

62. Brief for Petitioner at 30, Gideon v. Wainwright, 372 U.S. 335 (1963).

63. 310 U.S. 88 (1940).

64. 310 U.S. 321 (1940).

65. 312 U.S. 321 (1941).

66. Padway, History in the Making, 48 AM. FederalisT, Apr. 1941, at 22.

67. See Bakery \& Pastry Drivers Local No. 802 v. Wohl, 315 U.S. 769 (1942); Hotel \& Restaurant Employees' Intl. Alliance Local No. 122 v. Wisconsin Employment Relations Bd., 315 U.S. 437 (1942); Allen-Bradley Local No. 1111 v. Wisconsin Employment Relations Bd., 315 U.S. 740 (1942); Carpenters \& Joiners Union Local No. 213 v. Ritter's Cafe, 315 U.S. 722 (1942).

68. See, e.g., San Diego Bldg. Trades Council v. Garmon, 359 U.S. 236 (1959); Youngdahl v. Rainfair, Inc., 355 U.S. 131 (1957); Garner v. Teamsters Local Union No. 776, 346 U.S. 485 (1953). 
lead of the celebrated rulings to invalidate various prohibitions on peaceful picketing ${ }^{69}$ and that labor's legal spokesmen were convinced that "[c]omplete familiarity with them [was] as important to labor as tools to the craftsman."70

\section{Religious Freedom: Jehovah's Witnesses}

During the 1930's, the young religious sect known as the Jehovah's Witnesses generated widespread public hostility. The most formidable legal barriers to its practice of engaging in door-to-door canvassing on Sundays - which resulted in a wave of arrests - were local ordinances that forbade peddling without a permit (submission to which the Witnesses believed to be an insult to the Almighty) and barred leaflet distribution on the public streets. ${ }^{71}$ These impediments to the Witnesses' exercise of their religion were greatly ameliorated by a series of Supreme Court rulings commencing in 1938.72 Although it undoubtedly would be an oversimplification to attribute the subsequent decline in the group's conflicts with local police officials - and the dramatic increase in its American membership ${ }^{73}$ - exclusively to these decrees, it appears that, as stated by one of the sect's leading chroniclers, "[t]he Lovell and Schneider decisions . . . put the antiWitness forces once and for all on the defensive."74

The Jehovah's Witnesses' most serious clash with the established order was over the flag salute. By one count, as of 1940, Jehovah's Witness children who refused to salute the flag because of their religious beliefs were faced with actual or impending expulsion "in at least thirty-one states. According to Witness sources, expulsions took place in all forty-eight states and totaled more than 2,000 by $1943 .{ }^{\prime \prime} 75$ Furthermore, in some states, "there were attempts to have the children declared delinquent or dependent and removed from their parents. Prosecutions were brought against parents for school law violation or for contributing to the delinquency of their offspring, or for 'obstructing' the ceremony." 76 This grave threat to the faith's sur-

69. See Teller, Picketing and Free Speech, 56 HARv. L. REv. 180, 185-90 (1942).

70. Padway, Shackling Labor by Legislation, 47 AM. FEDERALIST, Aug. 1940, at 10.

71. See D. Manwaring, Render unto Caesar: The Flag Salute Controversy 2628 (1962).

72. See Schneider v. State, 308 U.S. 147 (1939); Lovell v. City of Griffin, 303 U.S. 444 (1938).

73. D. MANwaRING, supra note 71, at 20. Membership increased from about 28,000 in 1938 to over 72,000 in 1943. By 1955, membership had grown to 187,000 .

74. Id. at 28.

75. Id. at 187 .

76. Id. at 190 . 
vival was held unconstitutional by the Court in 1943.77 Although "[a]ttempts to enforce the [flag] salute requirement did not die out altogether immediately after Barnette," 78 on the whole - owing in no small measure to a vigorous offensive by the Department of Justice (as well as to a weakened public enmity toward the witnesses) ${ }^{79}$ state and local compliance with the Barnette ruling was immediate and substantial . . . . [T] he dearth of Witness complaints to the Justice Department about flag-salute expulsions, together with the almost total absence of new litigation, strongly suggests that Witness children were being readmitted to school in most localities without incident. ${ }^{80}$

\section{Company Towns}

In 1922 , it was estimated that over 300,000 soft-coal miners were deprived of "institutions of civil liberty that characterize the ordinary American urban center," because they resided in "company towns" in which "[p]eaceful and lawful attempts to exercise the right of public assembly are often violently opposed" and "[h]ouses are searched without warrants or with false warrants for lawful literature . . . and men are discharged for circulating such literature." And six years earlier, a national commission had found such communities not only in the mining areas but in the lumbering, turpentine and plantation types of agriculture industries as well. Furthermore, "striking examples existed also in manufacturing, particularly in textiles and steel." $" 81$

There appears to be no hard data demonstrating that the complete or nearly complete elimination of these conditions was a result of the 1946 ruling in Marsh v. Alabama, ${ }^{82}$ which imposed fourteenth amendment responsibilities on company towns. But, because of the virtual disappearance of the issue after that time, it is fair to infer that the Court's influence - as well as that of strengthened unions and the Wagner Act - was of real consequence.

\section{E. Racial Discrimination}

\section{Voting}

As of 1932, the problem of disenfranchisement of black citizens

77. West Virginia State Bd. of Educ. v. Barnette, 319 U.S. 624 (1943), overruling Minersville School Dist. v. Gobitis, 310 U.S. 586 (1940).

78. D. MANwaring, supra note 71 , at 242.

79. Id. at 250 .

80. Id. at 242.

81. Bowden, Freedom for Wage Earners, 200 ANNALS 185, 188-89 (1938).

82. 326 U.S. 501 (1946). 
was largely confined to twelve southern states. ${ }^{83}$ In that year, fewer than 100,000 blacks voted in general elections in these states, and virtually no blacks were permitted to vote in the primaries. ${ }^{84}$ No more than $2.5 \%$ of voting-age blacks in the deep south cast ballots in the presidential election of $1940 .^{85}$ Although literacy tests and poll taxes were significant contributing factors, the most formidable barrier was the "white primary" whose proscription by the Court in 1944,86 according to V.O. Key, "precipitated a crisis in southern politics." 87 Within four years of Smith v. Allwright, it was reported that "remarkable changes have taken place both in the practical voting arrangements and in the viewpoints of many people within the South, and, as a result, large numbers of Negroes were admitted to the Democratic primaries of 1944 and 1946."88 Blacks were also appointed poll tax deputies and precinct chairmen, ${ }^{89}$ and voter registration of blacks was heavy. 90

There is no disputing that it was only aggressive congressional and executive enforcement, culminating in the Voting Rights Act of 1965, that finally fulfilled the fifteenth amendment's promise. But the fact is that, within three years of the outlawing of the white primary, the number of registered black voters in the twelve southern states had

83. Alabama, Arkansas, Florida, Georgia, Louisiana, Mississippi, North Carolina, Oklahoma, South Carolina, Tennessee, Texas, and Virginia.

84. U.S. COMMN. ON CiVIL RIGHTS, BooK 1: VotiNg 21 (1961) [hereinafter cited as VoTING].

85. R. KLUGER, StMPLE JUSTICE 218 (1975).

86. Smith v. Allwright, 321 U.S. 649 (1944).

87. V. Key, Southern Politics in State and Nation 619 (1949). Despite manifold efforts of varying success to negate the decision's mandate in a number of states, those "around the rim of the Deep South accepted the new order more or less as a matter of course." Id. at 625.

88. Weeks, The White Primary: 1944-1948, 42 AM. PoL. ScI. Rev. 500 (1948). For example, in Texas, "since 1944, Negroes have been paying their poll taxes in greater numbers and have been admitted to Democratic primaries more or less freely in many counties." Id. at 503. In 1946, "[f]or the first time, Negro delegates were selected to county Democratic conventions in Dallas, Travis (Austin), and Harris (Houston) counties." Strong, The Rise of Negro Voting in Texas, 42 AM. PoL. SCI. REv. 510, 512 (1948).

89. Negro poll tax deputies were appointed by the county tax collector's office in Dallas, Tarrant (Fort Worth), Harris, and Travis Counties. Dallas had no fewer than 28 Negroes deputized to collect poll taxes, Houston 18. Finally, some Negro Democratic precinct chairmen turned up in colored precincts of the big cities - three in Dallas, five in Houston, two in Galveston, and one in Port Arthur.

Strong, supra note 88, at 512.

90. In Arkansas, "[r]egistration of Negroes for 1946 was reported as heavy, although attempts were made, it is alleged, to dissuade many from voting." Weeks, supra note 88, at 505. Even in Georgia, where there was extensive opposition to implementation, "[t]he state Democratic executive committee let down the bars for the primary of 1946 , and nearly $125,000 \mathrm{Ne}$ groes were registered $(100,000$ are supposed to have voted)"; the black vote "helped elect a congresswoman from the fifth Congressional district whose opponent had declared for "white supremacy." Id. at 506. 
risen to 645,000 and by 1952 this figure exceeded one million. 91 "The most important change," observed the Civil Rights Commission, "was the virtual elimination of 'white primaries' in 1944."92

\section{Housing}

In the first years following World War II, just before the Court's 1948 ruling in Shelley v. Kraemer ${ }^{93}$ - holding that judicial enforcement of racially restrictive covenants was unconstitutional - large numbers of black citizens throughout the nation "who had money to rent, buy, or build superior housing to live at a standard equal to their income"94 "were ready and willing, but unable, to move to new homes."95 Although plainly not the exclusive mechanism, 96 the covenant - widespread from east to west $^{97}$ and almost universally enforced by the courts ${ }^{98}$ — had become a major weapon for the perpetuation of racial separation in urban residential areas, 99 especially since 1917 when the Court had invalidated official racial segregation housing ordinances. ${ }^{100}$ When many blacks, assured by the NAACP of legal support, purchased homes despite the covenants, "at least a hundred injunctions to evict Negroes and dissolve their titles were brought by Caucasians."101

Of course, the Justices' edict in Shelley did not eliminate all devices to maintain housing segregation. In particular, "white property owners in all parts of the country received the co[o]peration of real-estate

91. Votang, supra note 84 , at 22.

92. Id. at 21 .

93. 334 U.S. 1 (1948).

94. Vose, NAACP Strategy in the Covenant Cases, 6 W. RES. L. REv. 101, 116 (1955).

95. Id. at 104-05.

96. See, e.g., G. MYrdal, AN American Dilemma 619 (1944); C. Vose, Caucasians ONLY 77, 100-07 (1959).

97. Covenants existed in such cities as Columbus, Detroit, Los Angeles, New York, St. Louis and Washington. C. Vose, supra note 96, at 155.

98. C. VOSE, supra note 96, at 1-29.

99. For example, a 1944 study found that in St. Louis, "559 block areas, or $51 / 2$ square miles of land space and housing, were withdrawn from the use of Negroes through the operation of restrictive covenants and agreements. More than 11 square miles were covered in Chicago." Id. at 9 (citing H. Long \& C. Johnson, People vs. Property: RaCe Restricted CoveNANTS IN HOUSING 32 (1947)).

100. Buchanan v. Warley, 245 U.S. 60 (1917).

101. Vose, supra note 94 , at 105 . Thus, it was reported in 1946 that more than twenty covenant suits, probably affecting a hundred Negro families, have been entered in Los Angeles alone. Chicago had about sixteen such suits pending at the end of 1945, which affected about fifty Negro families. A dozen or more have been instituted in Washington, D.C., several in St. Louis and Detroit, and others in scattered cities in the North.

F. Murray, The Negro Handbook 33 (1946-1947). 
boards in keeping Negroes from buying homes in residential areas traditionally reserved for whites." 102 But within three years of the decision, a United Press survey showed that "[t]housands of Negro families have moved into white residential neighborhoods across the country since the Supreme Court cracked down on anti-Negro housing restrictions in 1948."103 For example, "[i]n Chicago, it was estimated by the local Commission on Human Relations that within four years of the Shelley decision, 21,000 colored families purchased or rented homes in areas formerly barred to them." 104 Although no study has been found revealing the long-range integrative impact in these areas, there is no doubting the consequences of improved living conditions for many racial minorities. Finally, even those blacks who would have managed to evade restrictive covenants by using a "straw man" white broker in the transaction reportedly "saved millions of dollars by the Supreme Court's ruling" - "probably as much as $\$ 2,000$ per house on the average"105 - by eliminating a dual brokerage commission.

\section{Education}

Commencing with its decision in Missouri ex rel. Gaines $v$. Canada ${ }^{106}$ in 1938 and ending with Sweatt v. Painter ${ }^{107}$ and McLaurin v. Oklahoma State Regents ${ }^{108}$ in 1950 , the Court put teeth into the separate but equal doctrine in respect to public education by ordering black students to be admitted to state graduate and professional schools when no comparable segregated facilities existed. The response of the southern states was twofold - integration and parity.

First, by the fall of 1950, in compliance with the Justices' mandates, eleven states with segregation laws "lowered the racial bar in professional and graduate schools." It was reported "that 1,000 or more Negroes were attending classes with white students in the $17 \mathrm{Jim}$ Crow states." 109 Second, and more consequential, in order "to remedy

102. C. VosE, supra note 96 , at 223.

103. N.Y. Times, Jan. 22, 1951, at 19, col. 8.

104. R. KLUGER, supra note 85 , at 255 (1975). Similar information came from such cities as Chicago, Denver, Detroit, Los Angeles, New York and St. Louis, C. Vose, supra note 96, at 227, and in the District of Columbia, "[a]ccording to the 1950 census, of the 3,887 residential blocks . . . non-white accommodations had spread into 459 more than in 1940." R. KLUGER, supra, at 255.

105. N.Y. Times, supra note 103.

106. 305 U.S. 337 (1938).

107. 339 U.S. 629 (1950).

108. 339 U.S. 637 (1950).

109. Konvitz, The Courts Deal a Blow to Segregation, 11 CoMmentary 158, 162 (1951).

Thus the University of Oklahoma enrolled 60 Negroes; the University of Texas, 21; the 
a hundred years of neglect" - as Governor James E. Byrnes of South Carolina frankly confessed ${ }^{110}$ - and concededly to ward off the threatened demise of the school segregation principle altogether lest the Court "take matters out of the state's hands,"111 the states of the deep south engaged in "frenzied spending campaigns and gigantic efforts . . . to equalize the educational opportunities of white and Negro pupils." "112 A modest illustration is found in the record of the Sweatt case itself: Texas opened its School of Law of the Texas State University for Negroes only after the trial court had held that the state must supply substantially equal facilities. More dramatic examples were South Carolina's $\$ 75$ million school bond effort, ${ }^{113}$ Virginia's $\$ 60$ million "Battle Fund,"114 Mississippi's \$46 million school "overhaul" program, ${ }^{115}$ and Georgia's $\$ 30$ million "equalization" plan. ${ }^{116}$ But probably the best evidence of the impact of these decisions on civil rights lies in the statistics compiled in the Biennial Survey of Education in the United States which quantify the extraordinary increases in expenditures for the education of blacks in the South, both in terms of expenditure per pupil and average teachers' salaries. ${ }^{117}$

University of Arkansas, 12; the University of Kentucky, 15; the University of Missouri, 9; the University of Virginia, 3. The University of Louisville admitted 18 Negroes. . . . [Two hundred] Negro students were engaged in graduate and professional studies at the University of Arkansas; the University of Kansas City had 54.

Other sources disclosed the attendance of blacks in state universities in Tennessee, Comment, Constitutional Law - Equal Protection of the Laws - Segregation of Negroes in Public Schools, 24 S. CAL. L. Rev. 74, 82 (1950), and Louisiana, SoutherN School News, Sept. 3, 1954, at 13, col.1.

110. See Kelly, The School Desegregation Case, in QuARRELS That HAVE SHAPEd THE Constitution 243, 256 (J. Garraty ed. 1964).

111. Id. at 256.

112. R. Harris, The Quest for Equality 139 (1960).

113. See Briggs v. Elliott, 98 F. Supp. 529, 531 (E.D.S.C. 1951).

114. See Argument: The Oral Argument before the Supreme Court in Brown $v$. BOARD OF EDUCATION OF TOPEKA, 1952-55 at 83, 89 (L. Friedman ed. 1969) [hereinafter cited as ARGUMENT]. The "Battle Fund" was named coincidentally after the incumbent governor.

. 115. See Leflar \& Davis, Segregation in the Public Schools - 1953, 67 HARv. L. REv. 377, 421 n.144 (1954).

116. See N.Y. Times, Apr. 22, 1951, at 58, col. 3.

117. The statistics are as follows: 


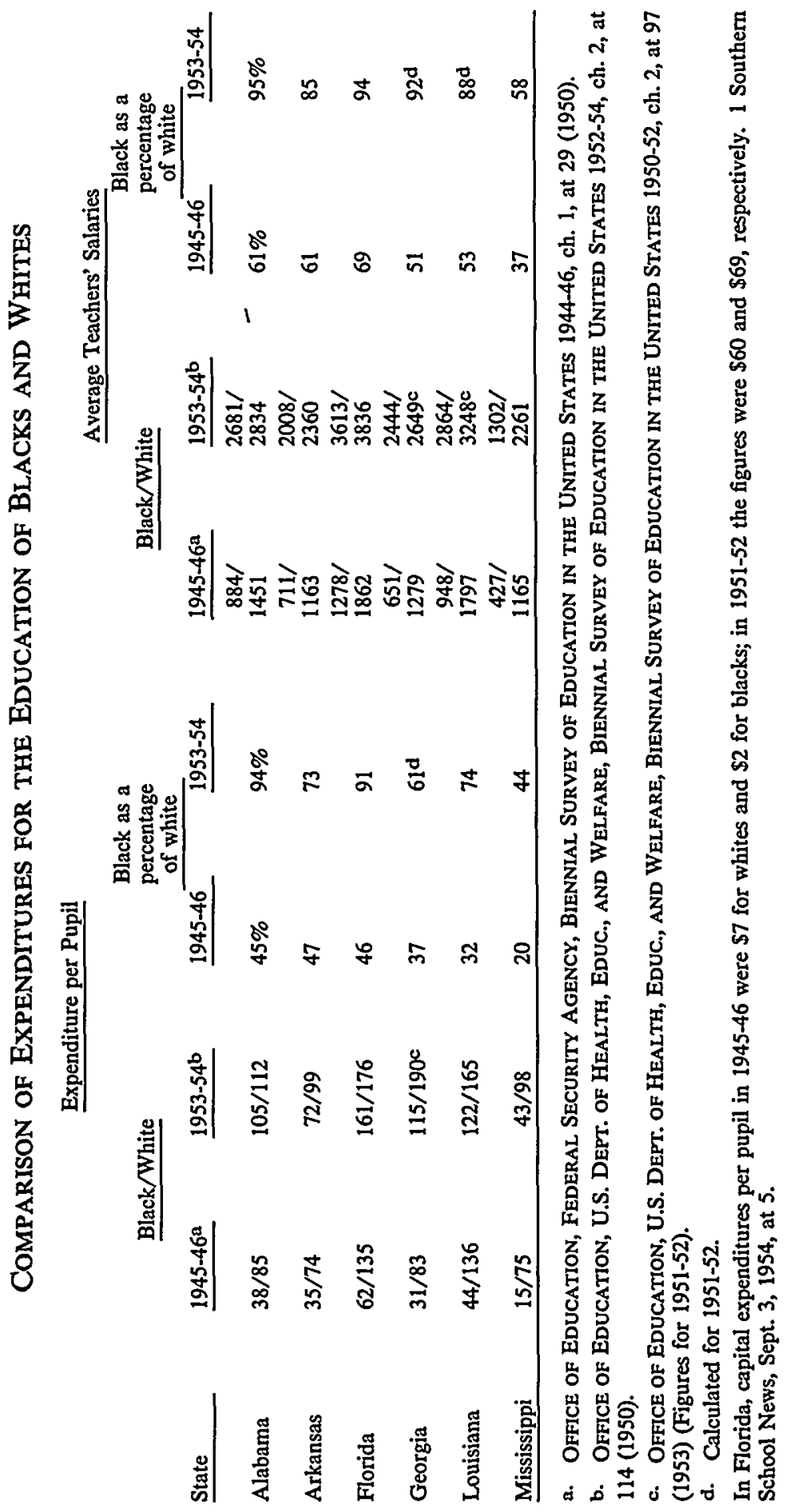




\section{ThE WARREN COURT}

\section{A. Racial Separation}

\section{Segregation}

The subject of official hostility against the nation's black and ethnic minorities provides the most direct bridge to the period between 1953 and 1969. It plainly fell to the Warren Court ultimately to fulfill the promise of the equal protection clause by repudiating racial segregation in 1954 for, at least until then, the national and state political organs remained silent. As Justice Jackson remarked during oral argument in the Virginia and South Carolina suits, "I suppose that realistically the reason this case is here was that action couldn't be obtained from Congress."118

The pervasiveness of the American system of apartheid may be i1lustrated by the fact that

In May of 1951, the state of Texas did not allow interracial boxing matches.

Florida did not permit white and black students to use the same editions of some textbooks.

In Arkansas, white and black voters could not enter a polling place in the company of one another.

In Alabama, a white woman was forbidden to nurse a black man in a hospital.

North Carolina required racially separate washrooms in its factories. South Carolina required them in its cotton mills. Four states required them in their mines.

In six states, white and black prisoners could not be chained together.

In seven states, tuberculosis patients were separated by race.

In eight states, parks, playgrounds, bathing and fishing and boating facilities, amusement parks, racetracks, pool halls, circuses, theaters, and public halls were all segregated.

Ten states required separate waiting rooms for bus and train travelers.

Eleven states required Negro passengers to ride in the backs of buses and streetcars. Eleven states operated separate schools for the blind.

Fourteen states segregated railroad passengers on trips within their borders. Fourteen states segregated mental patients.

And in May of 1951 seventeen states required the segregation of public schools, four other states permitted the practice if local communities wished it, and in the District of Columbia the custom had prevailed for

118. ARGUMENT, supra note 114, at 244. Indeed, two years after Brown v. Board of Educ., 347 U.S. 483 (1954), less than half the populace approved of black children attending the same schools as whites. See J. CASPER, THE POLITICs OF CIVIL LIBERTIEs 169 (1972). 
nearly ninety years. ${ }^{119}$

Statistical evidence disclosed that, by the end of the decade following the Justices' decree in Brown v. Board of Education, ${ }^{120}$ more than half the black pupils enrolled in the border jurisdictions - Delaware, Kentucky, Maryland, Missouri, Oklahoma, West Virginia, and the District of Columbia - attended integrated schools. ${ }^{121}$ Although wide-scale implementation of Brown's ban on legally imposed school segregation was accomplished only after the political branches afforded coercive support in the Civil Rights Act of 1964, it was the Court's mandate that provided the indispensable impetus. Of course, the story of school desegregation still remains unfinished, particularly in respect to the extremely controversial issue of busing, the effectiveness of which has been judged by various observers as ranging from significant success to dismal failure. ${ }^{122}$ Moreover, even if in the long run, socio-economic facts and politico-psychological attitudes render "the nationalizing, egalitarian, assimilationist conception of the public schools' mission" 123 to be either unattainable or unwanted, as of the early 1980's the facts remain that "white opposition to integrated schools has dropped considerably; . . . black drop-out rates . . . have fallen; and the proportion of black youngsters attending college has risen tremendously." 124 In sum, there is no demeaning the significance for individual liberty - both pragmatically and symbolically of the elimination of enforced racial separation in schools and all other public facilities.

More important, however, it must be acknowledged that the overall consequences of the Court's historic ruling and its major contribution to the advancement of racial justice in the United States radiated far beyond the cold statistics in southern schoolhouses. Although a congeries of complex factors contributed to the civil rights upheaval in the 1960's, ${ }^{125}$ in the words of Anthony Lewis, Brown v. Board of Education was the "catalyst" for "the revolution in American race relations," creating

a climate that encouraged the Negro to protest against segregation on buses, to demand coffee at a lunch counter, to stand in long, patient lines

119. R. KLUGER, supra note 85 , at 327 .

120. 347 U.S. 483 (1954).

121. See U.S. Commn. ON Civil Rights, Public Education 292 (1964).

122. See Daniels, In Defense of Busing, N.Y. Times, Apr. 17, 1983, $\S 6$ (Magazine), at 34.

123. A. Bickel, The Supreme Court and the Idea of Progress 137 (1970).

124. Rustin, Integration and Education: 25 Years After Brown, 23 How. L.J. 89, 91-92 (1980).

125. See Yudof, Equal Educational Opportunity and the Courts, 51 TEx. L. REv. 411, 468-69 (1973). 
waiting to take a biased test for the right to vote. . . . It took the drama of school desegregation, and then of the protest movements, to make the possibility of freedom come alive . . . 126

Robert Carter similarly found that in Brown,

the psychological dimensions of America's race relations problem were completely recast. . . . As a result, the Negro was propelled into a stance of insistent militancy. Now he was demanding - fighting to secure and possess what was rightfully his. The appeal to morality and to conscience still was valid, of course, but in a nation that was wont to describe itself as a society ruled by law, blacks had now perhaps the country's most formidable claim to fulfillment of their age-old dream of equal status - fulfillment of their desire to become full and equal participants in the mainstream of American life. ${ }^{127}$

Furthermore, the "social upheaval" fathered by this judicial doctrine ${ }^{128}$ provided the political branches of national government with both the moral courage and intellectual bases for combating discrimination in voting and opening employment opportunities for minorities. ${ }^{129}$

Black leaders from all walks of life have attested that Brown sparked an eruption of emotion and energy in the "hearts and minds" of black Americans, young and old, "in a way unlikely ever to be undone."130 Louis Lomax explained that "[i]t would be impossible for a white person to understand what happened within black breasts on that Monday. . . . That was the day we won; the day we took the white man's laws and won our case before an all-white Supreme Court with a Negro lawyer . . . . And we were proud."131 Richard Kluger observed that

[e]very colored American knew that Brown did not mean he would be invited to lunch with the Rotary the following week. It meant something more basic and more important. It meant that black rights had suddenly been redefined; black bodies had suddenly been reborn under a new law. Blacks' value as human beings had been changed overnight by

126. A. Lewis, Portrait of a Decade 5, 8-9 (1964). Indeed, Kenneth Karst has observed that the Justices" desegregation rulings not only "forever alter[ed] the substance and the tone of race relations in this country; they made us question the validity of all sorts of systems of dominance and dependency," thus "set[ting] in motion forces (moral and political) that fostered other 'liberation' movements." Karst, Foreword: Equal Citizenship Under the Fourteenth Amendment, 91 HARV. L. REV. 1, 21 (1977); see also Glickstein, The Impact of Brown v. Board of Education and its Progeny, 23 How. L.J. 51, 53 (1980) ("The movement to secure the rights of black Americans has fostered concern for the rights of women, Indians, Chicanos, Puerto Ricans, various other ethnic groups, the mentally and physically handicapped, prisoners, children, the aged and those with special sexual preferences.").

127. Carter, The Warren Court and Desegregation, 67 MICH. L. REv. 237, 247 (1968).

128. Id. at 246.

129. See Glickstein, supra note 126, at 51-52.

130. The phrases come from Brown, 347 U.S. at 494.

131. L. LomaX, The Negro Revolt 73-74 (1962). 
the declaration of the nation's highest court. At a stroke, the Justices had severed the remaining cords of de facto slavery. The Negro could no longer be fastened with the status of official pariah. No longer could the white man look right through him as if he were, in the title words of Ralph Ellison's stunning 1952 Novel, Invisible Man. No more would he be a grinning supplicant for the benefactions and discards of the master class; no more would he be a party to his own degradation. He was both thrilled that the signal for the demise of his caste status had come from on high and angry that it had taken so long and first exacted so steep a price in suffering. ${ }^{132}$

\section{Miscegenation}

One of the later of the Warren Court's major interventions in favor of individual rights uprooted one of the most passionately held barriers to full racial freedom. Fifteen years prior to the Justices' 1967 ruling in Loving $v$. Virginia ${ }^{133}$ which held that laws forbidding interracial marriage violated equal protection, twenty-nine states had such statutory provisions. ${ }^{134}$ Between 1953 and 1967, thirteen of these states repealed their antimiscegenation laws, ${ }^{135}$ galvanized in part by a constitutional decision of the California Supreme Court ${ }^{136}$ and in part by the success of the revolutionary movement toward racial equality engendered by the School Segregation Cases. ${ }^{137}$ Still, as late as 1967, the statutes of sixteen states continued to prohibit miscegenous marriages. ${ }^{138}$

132. R. KIUGER, supra note 85 , at 749. In the opening paragraphs of "Soul on Ice," Eldridge Cleaver wrote from Folsom Prison:

Nineteen fifty-four, when I was eighteen years old, is held to be a crucial turning point in the history of the Afro-American - for the U.S.A. as a whole - the year segregation was outlawed by the U.S. Supreme Court. It was also a crucial year for me because on June 18, 1954, I began serving a sentence in state prison for possession of marijuana.

The Supreme Court decision was only one month old when I entered prison, and I do not believe that I had even the vaguest idea of its importance or historical significance. But later, the acrimonious controversy ignited by the end of the separate-but-equal doctrine was to have a profound effect on me. This controversy awakened me to my position in America and I began to form a concept of what it meant to be black in white America.

E. Cleaver, Soul on ICE 3 (1968).

133. 388 U.S. 1 (1967).

134. See Applebaum, Miscegenation Statutes: A Constitutional and Social Problem, 53 GEo. L.J. 49, 50 (1964).

135. The repealing states were Arizona, Colorado, Idaho, Indiana, Maryland, Montana, Nebraska, Nevada, North Dakota, Oregon, South Dakota, Utah and Wyoming. 388 U.S. at 6 n.5; Applebaum, supra note 134, at 50 n.12; Note, Miscegenation: An Example of Judicial Recidivism, 8 J. FAM. L. 69, 70 (1968).

136. Perez v. Lippold, 32 Cal. 2d 711, 198 P.2d 17 (1948).

137. See Applebaum, supra note 134, at 50. See generally Zabel, Interracial Marriage and the Law, The ATL. MoNTHLy, Oct. 1965, at 75 (discussing the origins and extent of antimiscegenation statutes and the prospects of the then up-and-coming Loving case).

138. Alabama, Arkansas, Delaware, Florida, Georgia, Kentucky, Louisiana, Mississippi, Missouri, North Carolina, Oklahoma, South Carolina, Tennessee, Texas, Virginia, and West Virginia. 388 U.S. at 6 n.5. 
The consequences of these laws were not inconsiderable. Ordinarily, the laws applied not only to marriages consummated within the prohibiting state but also to persons of different races who married outside such states and subsequently came to live in the state with an antimiscegenation law. ${ }^{139}$ In some states where such unions were illegal, violation subjected the parties to prosecution for a felony. ${ }^{140}$ Penalties ranged from thirty days (where the offense was only a misdemeanor) up to five-to-ten years. ${ }^{141}$ In the 1940 's, prison terms were not infrequently imposed. ${ }^{142}$

The antimiscegenation laws also produced serious noncriminal ramifications. Because the statutes made interracial marriages void, all offspring were considered illegitimate. Children and surviving spouses were denied the right to intestate inheritance, to take property under a will, to be granted letters of administration, and to receive worker's compensation benefits. ${ }^{143}$ In the late 1950 's, black servicemen who had married white women while on European tours of duty, on return to the United States, were transferred from their military units when their divisions were stationed in jurisdictions that barred racially mixed unions. 144

These varied disabilities of antimiscegenation laws - all with "the ultimate aim of preventing interracial couples from having any legal peace of mind"145 - were removed by the Loving decision. The exact number of persons that Loving directly affected is incalculable. However a 1956 survey, which indicated that in states where mixed marriages were lawful perhaps five percent of blacks had spouses of a

139. 388 U.S. at 2-3; see Applebaum, supra note 134, at 55-56.

140. Applebaum, supra note 134, at 53 n.41. Many of the statutes also made it a crime for any person to perform a marriage ceremony for an interracial couple or to issue a marriage license to them. Id. at 54. The effect of this prohibition was confirmed by a widely publicized incident in 1958 when county clerks in Nevada rebuffed longshoreman leader Harry Bridges three times after he applied for permission to marry a Japanese-American woman. See Mixed Marriages - And an Exception, NEwSWEEK, Dec. 22, 1958, at 20.

141. Applebaum, supra note 134, at 53.

142. See, e.g., State v. Miller, 224 N.C. 183, 29 S.E.2d 744 (1944) (length of sentence not stated); Till Law Us Do Part, NEWSWEEK, Jan. 19, 1948, at 25 (six-month sentence in Virginia). In 1959, the principals in the Loving case "were sentenced to one year in jail; however, the trial judge suspended the sentence for a period of 25 years on the condition that the Lovings leave the State and not return to Virginia together for 25 years." 388 U.S. at 3.

143. See cases and authorities cited in Applebaum, supra note 134, at 54-55; Note, supra note 135, at 71-72. Indeed, as recently as 1965 , even after the Court had invalidated laws that imposed special penalties for interracial cohabitation, McLaughlin v. Florida, 379 U.S. 184 (1964), the United States Comptroller General's office refused military death benefits to the black widow of a deceased white soldier because they had wed in a state forbidding miscegenous marriages. See Seidelson, Miscegenation Statutes and the Supreme Court, 15 CATH. U. L. REv. 156, 156-57 (1966).

144. U.S. NEWS \& WORID REPORT, Oct. 11, 1957, at 110.

145. Note, supra note 135 , at 72 . 
different race, ${ }^{146}$ suggests the breadth of Loving's impact on individual constitutional rights.

\section{B. Rights of the Accused}

\section{Exclusionary Rule}

It was up to the Court to strike forcefully against unreasonable searches and seizures in 1961 in Mapp $v$. Ohio 147 because the legislative process had not. Twelve years had passed since the Court informed the states that they were bound by the fourth amendment, ${ }^{148}$ yet still more than half continued to admit into evidence the fruits of illegal searches and seizures. ${ }^{149}$

The extent to which the exclusionary rule has deterred official misconduct and thus secured the fourth amendment's promise of freedom is a matter of substantial debate. Some empirical surveys ${ }^{150}$ - the methodology of which has been sharply criticized ${ }^{151}$ — have simply concluded that Mapp's stricture is ineffective, thus supporting the view that the Court's efforts on behalf of individual liberty have been largely inconsequential. The most celebrated review, by Dallin Oaks, returns an inconclusive verdict: "The data contains little support for the proposition that the exclusionary rule discourages illegal searches and seizures, but it falls short of establishing that it does not."152 Perhaps the only position that may be taken with confidence is that Mapp's "deterrent efficacy defies precise measurement."153

146. U.S. NEWS \& WORLD REPORT, Oct. 7, 1963, at 63.

147. 367 U.S. 643 (1961).

148. Wolf v. Colorado, 338 U.S. 25, 28 (1949).

149. 367 U.S. at 652 n.7. This should not be particularly surprising. Students of police behavior have observed that the law enforcement profession is extremely sensitive and commonly resistant to regulation from without, see J. WILSON, VARIETIES OF POLICE BEHAVIOR 231-32 (1968); Reiss \& Bordua, Environment and Organization: A Perspective on the Police, in THE PolicE: Six Sociological Essays 25, 38-39 (D. Bordua ed. 1967), thus making legislative control, according to Anthony Amsterdam, a "politically suicidal undertaking." Amsterdam, Perspectives On The Fourth Amendment, 58 MINN. L. REv. 349, 379 (1974).

150. See, e.g., Spiotto, Search and Seizure: An Empirical Study of the Exclusionary Rule and Its Alternatives, 2 J. LEGAL STUD. 243 (1973).

151. See Canon, The Exclusionary Rule: Have Critics Proven That It Doesn't Deter Police?, 62 JUDICATURE 398 (1979); Critique, On the Limitations of Empirical Evaluations of the Exclusionary Rule, 69 Nw. U. L. REv. 740 (1974).

152. Oaks, Studying the Exclusionary Rule in Search and Seizure, 37 U. CHI. L. REv. 665, 667 (1970). Again, however, the underlying evidence has been challenged as being "insufficient and largely inappropriate." Canon, Is the Exlusionary Rule in Failing Health? Some New Data and a Plea against Precipitous Conclusion, 62 KY. L.J. 681, 698 (1974). The nature of the research enterprise generally - which seeks to measure that which cannot be directly observed has been said to be skewed against demonstrating the rule's achievements. Morris, The Exclusionary Rule, Deterrence and Posner's Economic Analysis of Law, 57 WASH. L. REV. 647, 653 (1982).

153. LaFave, Improving Police Performance Through the Exclusionary Rule - Part I: Cur- 
To concede that the exclusionary rule falls short of curing the disease and that it produces the undesired side effect of preventing otherwise justified criminal convictions, ${ }^{154}$ however, does not refute its prophylactic value - at least until a more effective antidote is discovered. ${ }^{155}$ For, although the rule "does not produce police conformity with the requirements of law in all cases," it "does have a significant impact upon police practice in some situations."156 While "[t]he evidence consists only of bits and pieces, . . . the fragments indicate it is a mistake to think that police behavior is never conditioned by the sanction of excluding evidence that might lead to conviction."157 Many lawyers, judges, and law enforcement officials have expressed the opinion that Mapp has induced police departments into avoiding illegal searches. ${ }^{158}$ In an intensive study of the administration of crim-

rent Police and Local Court Practices, 30 Mo. L. REv. 391, 395 (1965). See generally D. Horowitz, The CourTs AND Social Policy 220-54 (1977).

154. The extent to which the number of such lost convictions may be exaggerated is discussed in Kamisar, How We Got the Fourth Amendment Exclusionary Rule and Why We Need It, CRIM. JUST. ETHICS, Summer-Fall 1982, at 4, 11; Sachs, The Exclusionary Rule: A Prosecutor's Defense, Crim. Just. ETHICS, Summer-Fall 1982, at 28, 29. But see U.S. Dept. OF JusticE, Criminal Justice Research Report, The Effects of the Exclusionary RUle: A STUDY IN CALIFORNIA 18 (1982) ("[T] he exclusionary rule does appear to be an important factor in the processing of state felony cases.").

155. See, e.g., Newman, Suing the Lawbreakers: Proposals to Strengthen the Section 1983 Damage Remedy for Law Enforcers' Misconduct, 87 YALE L.J. 447 (1978); Schroeder, Deterring The Fourth Amendment Violations: Alternatives to the Exclusionary Rule, 69 GEo. L.J. 1361 (1981).

156. W. LaFave, ARrest: The Decision to Take a Suspect into Custody 428 (1965); see also Canon, supra note 151, at 403 ("Existing data at the present time make it impossible to establish empirically a universal 'yes, it works' or a 'no, it doesn't work' conclusion. . . ."). But see Schlesinger, The Exclusionary Rule: Have Proponents Proven That It Is a Deterrent to Police?, 62 JudicaTuRE 404 (1979) ("[T] he available evidence doesn't even come close" to showing that the exclusionary rule is an effective deterrent.).

157. D. HorowrTz, supra note 153, at 230. For example, although the District of Columbia police had been conducting "random stops" of cars for license or registration checks in the absence of articulable suspicion to believe that criminal activity was afoot, when the Court rejected the practice in Delaware v. Prouse, 440 U.S. 648 (1979),

"[t]he Chief of Police issued an immediate telex message to his officers, advising them to desist from the practice" and then "incorporat[ed] the change in procedures in the Department's General Orders, a set of regulations issued to each officer and with which each officer must be familiar." Moreover, even before the ultimate Supreme Court decision in Prouse, the Delaware State Police Legal Officer, in response to the trial court's invalidation of "random stops," "had disseminated a memorandum to all troops and units within the State Police describing the decision, explaining the conduct it prohibited . . . advising that it did not affect the stops based on articulable suspicion," and "provid[ing] several examples of facts that could provide sufficient articulable suspicion for a stop."

Kamisar, Does (Did) (Should) the Exclusionary Rule Rest on a "Principled Basis" Rather Than an "Empirical Proposition"?. 16 CREIGHTON L. REv. 565, 660-61 (1983) (quoting Mertens \& Wasserstrom, Foreword: The Good Faith Exception to the Exclusionary Rule: Deregulating the Police and Derailing the Law, 70 GEO. L.J. 365, 400 (1981)).

158. A substantial majority of prosecutors, defense lawyers, and judges surveyed in North Carolina agreed that "[e]xclusion of evidence is an effective way of reducing the number of illegal searches." Katz, The Supreme Court and the States: An Inquiry into Mapp v. Ohio in North Carolina, 45 N.C. L. REv. 119, 134 (1966). Similar views were expressed by police officials, 
inal justice in Oakland, Jerome Skolnick concluded that "the exclusionary principle puts pressure on the police to work within the rules in those cases where prosecution is contemplated."159

Further, at least in some areas, "[i]t is clear that the exclusionary rule has served as a stimulus to police training on the legal requirements of search and arrest." 160 Thus, the New York City police commissioner could

think of no decision in recent times in the field of law enforcement which had such a dramatic and traumatic effect as [Mapp]. . . . Retraining sessions had to be held from the very top administrators down to each of the thousands of foot patrolmen and detectives engaged in the daily basic enforcement function. Hundreds of thousands of man-hours had to be devoted to retraining 27,000 men. ${ }^{161}$

Early reports from several cities found that police use of search warrants increased enormously after the Mapp decision. ${ }^{162}$ A recent extensive survey of police attitudes concerning the exclusionary rule found that it "probably had a significant effect on police behavior be-

public defenders, and judicial officers in small towns and rural areas of southern Illinois and western Massachusetts; "[i]n general, the judges saw the police departments as making fewer illegal searches, as operating more carefully in their work, and as educating the men of the departments so that a situation won't arise where evidence will be suppressed." S. WASBY, supra note 27, at 113-14; see also Canon, Testing the Effectiveness of Civil Liberties Policies at the State and Federal Levels, 5 AM. Polmics Q. 57 (1977).

159. J. Skolnick, Justice WITHout Trial 224 (1966). As the Attorney General of Maryland recently observed, many prosecutors - both state and federal - routinely review the quan. tum of probable cause with police officers before a seizure is made because they "want the search to stand up in court." Sachs, supra note 154, at 30. Evidence gleaned from such cities as Baltimore, Boston, Buffalo, Detroit, New York, Philadelphia, San Francisco, and Washington indicates "that to a considerable extent the rule is producing the impact that was intended." Canon, supra note 152, at 698; see also Kamisar, Public Safety v. Individual Liberties: Some "Facts" and "Theories," 53 J. Crim. L. Criminology \& Police SCI. 171, $179-82$ (1962).

160. LaFave, Improving Police Performance Through the Exclusionary Rule - Part II: Defining the Norms and Training the Police, 30 Mo. L. REv. 566, 594 (1965); see also S. WASBY, supra note 27 , at 107-08.

161. Murphy, Judicial Review of Police Methods in Law Enforcement: The Problem of Compliance by Police Departments, 44 TEX. L. REV. 939, 941 (1966). Similarly, in the FBI training program,

agents spend . . . thirty hours learning how to apply constitutional law principles to practice arrest, searches, interrogations, and applications for search warrants. Each FBI field office has a legal advisor to keep field agents abreast of current changes in the law.

All other new federal enforcement agents ... [devote] a minimum of twenty-one hours to search and seizure law. ...

Customs Department agents continue training for approximately five more weeks, spending ten to twelve hours on additional search and seizure problems with particular emphasis on those problems relating to customs agents, for example, border searches. The Drug Enforcement Administration emphasizes search and seizure law in an additional twenty-four hours and focuses on its particular need, airport searches. . . .

In [Maryland], Mapp has been responsible for a virtual explosion in the amount and quantity of police training in the last twenty years.

Sachs, supra note 154, at 31 .

162. See Murphy, supra note 161, at 941-42; Specter, Mapp v. Ohio, Pandora's Problems for the Prosecutor, 111 U. PA. L. REV. 4 (1962). 
cause it seemed to 'mean business' as a matter of law as much as because of any deterrent sanction which it may have imposed."163

At the very least, Mapp "provides a counterweight within the criminal justice system that prevents the system from functioning as an unmitigated inducement to policemen to violate the fourth amendment on every occasion when there is criminal evidence to be gained by doing so."164 Regardless of whether or not the rule deters the police from violating the search and seizure guarantee, its repeal "would positively encourage such unconstitutional activity."165

\section{Equality for the Poor}

a. At trial. When Gideon v. Wainwright ${ }^{166}$ was decided in 1963, the number of states that provided counsel for all or virtually all indigent felony defendants who so requested had increased from thirtyfive, at the time of Betts v. Brady, ${ }^{167}$ to forty-five. ${ }^{168}$ Thus, Gideon's greatest impact was felt by the destitute accused in only five states. ${ }^{169}$ Indeed, even in those states, some cities and counties regularly assigned lawyers for the trial of poor persons who were charged with serious crimes. ${ }^{170}$ But this is not to suggest that Gideon was of only minor significance for individual rights. In Florida alone, in the first few months after the Justices' ruling, " 1,000 prisoners were released because prosecutors could not or would not attempt to reprosecute. Of those 300 plus who were retried, most had their sentences reduced."171 Further, "to facilitate compliance with Gideon (and other subsequent implementing cases), legislatures and courts in twenty-six states took specific actions within twenty-four months to expand or improve their assigned counsel or public defender systems in varying degrees"172 - efforts that, as we shall see, ${ }^{173}$ provided lawyers for

163. Loewenthal, Evaluating the Exclusionary Rule in Search and Seizure, 49 UMKC L. REV. 24, 30 (1980).

164. Amsterdam, supra note 149 , at 431.

165. Johnson, New Approaches to Enforcing the Fourth Amendment 4 (1978) (working paper) (on file in the University of Michigan Law Library), quated in Kamisar, supra note 157, at 659 n.529 (emphasis in original).

166. 372 U.S. 335 (1963).

167. 316 U.S. 455 (1942).

168. Brief for Petitioner at 29-30, Gideon v. Wainwright, 372 U.S. 335 (1963).

169. Alabama, Florida, Mississippi, North Carolina, and South Carolina. See Kamisar, The Right to Counsel and the Fourteenth Amendment: A Dialogue on "The Most Pervasive Right" of an Accused, 30 U. CHI. L. REV. 1, 19 (1962).

170. Id. at 20.

171. S. WASBY, supra note 18 , at 8 .

172. G. Mrtau, Decade of Decision 161 (1967).

173. See text at notes $814-17$ infra. 
many accused indigent misdemeanants as well as persons charged with more grievous offenses.

There is no denying the substantial difficulties that have arisen "because of inadequate financing of defense services and a lack of sufficient qualified attorneys to handle the indigent caseload," 174 and that, at least in certain large cities in which assigned counsel systems function, some degree of assembly-line justice undoubtedly results, thus producing less than the Supreme Court's sixth amendment rulings appear to promise. ${ }^{175}$ Nonetheless, given the fact that, as of 1980, state and local governments were estimated to spend $\$ 30$ million annually for defense services, ${ }^{176}$ from the perspective of the security of personal liberty, surely even this form of legal representation is better than none at all.

It well may be - as subsequent discussion will explore in detail ${ }^{177}$ - that the most profound impact of the Gideon decision' came through its catalytic force in changing the perception of both the bar and the laity as to the need for a lawyer's assistance at other stages and levels of the criminal justice process. More directly, however, its greatest immediate significance can be measured only when viewed in combination with the Court's rule established in Carnley v. Cochran ${ }^{178}$ - that "where the assistance of counsel is a constitutional requisite, the right to be furnished counsel does not depend on a request. . . . [Rather,] [t]he record must show . . . that an accused was offered counsel but intelligently and understandingly rejected the offer."179 As of the early 1960 's, it appeared that in a majority of the forty-five states that mandated counsel for all indigent felony defendants, this right was afforded only "on request" of the accused. ${ }^{180}$ It is uncertain whether this meant, as it did in at least some states, ${ }^{181}$ that the accused was always first advised of his rights; or whether the accused obtained

174. Lefstein \& Portman, Implementing the Right to Counsel in State Criminal Cases, 66 A.B.A. J. 1084, 1086 (1980).

175. See Blumberg, The Practice of Law as Confidence Game: Organizational Cooptation of a Profession, 1 LAW \& Socy. REv. June 1967, at 15. But see Skolnick, Social Control in the Adversary System, 11 J. CONFlict Resolution 52, 59-68 (1967).

176. Lefstein \& Portman, supra note 174, at 1087.

177. See text at note 367 infra.

178. 369 U.S. 506 (1962).

179. 369 U.S. at 513, 516. Carnley enunciated this rule most emphatically, though it had earlier origins. See McNeal v. Culver, 365 U.S. 109 (1961); Uveges v. Pennsylvania, 335 U.S. 437 (1948); see also Johnson v. Zerbst, 304 U.S. 458 (1938).

180. See ASSN. OF N.Y.C. BAR \& NATL. LEGAL AID ASSN., EQUAL Justice For THE ACCUSED app., at 98-111 (1959) [hereinafter cited as EQUAL JUSTICE]; 365 U.S. app., at 119-22; Kamisar, supra note 169, at 14-21 (22 of 37 states); id. app. I, at 67-74 (3 of 8 states).

181. See EQUAL JusTiCE, supra note 180, at 49 (New Jersey). 
counsel only if he solicited assistance on his own initiative. If the latter were true, as was found to be so in at least eight states, ${ }^{182}$ then, irrespective of how broad the sixth amendment right might be, it is reasonable to infer that a sizable percentage of those for whom the protection was intended would not receive it. ${ }^{183}$ The Court's stringent waiver rule in Carnley corrected this in respect to the right to counsel at trial.

b. On appeal. Prior to the Court's decisions in Griffin v. Illinois ${ }^{184}$ and Douglas v. California, ${ }^{185}$ the practice in each of the then forty-eight states respecting the rights of indigents to receive free transcripts or appointed counsel on appeal of their criminal convictions was uncertain. ${ }^{186}$ But it was well-established that a large percentage of persons convicted of crime were indigent (estimates often exceeded fifty percent) ${ }^{187}$ and that a significant number of criminal convictions were reversed when appealed (statistics sometimes surpassed forty percent). ${ }^{188}$

In 1955, counsel for petitioner in Griffin reported that nineteen states refused to provide free trial transcripts to indigents who sought to appeal their convictions of noncapital offenses. ${ }^{189}$ Shortly thereafter, a more detailed and comprehensive survey indicated that twentyone states did not afford free transcripts for noncapital felony appeals. ${ }^{190}$ The more important finding of the latter study, however, was that within three years of the Griffin ruling more than two-thirds of these states appeared to have formally altered their procedures to re-

182. See Van Alstyne, In Gideon's Wake: Harsher Penalties and the "Successful" Criminal Appellant, 74 YALE L.J. 606 n.5 (1965).

183. This inference is confirmed by an empirical study of the operation of the Miranda rule which showed that, while almost two-thirds of arrestees who were informed of their right to counsel requested assistance, more than three-fourths of those who were not so advised failed to exercise the right. See Medalie, supra note 27, at 1371-72.

184. 351 U.S. 12 (1956).

185. 372 U.S. 353 (1963).

186. In a number of states no statute addressed the subject. Even if there had been a consistent pattern in each state and some persons had known of it, no empirical study systematically documented the law in action in every jurisdiction in the country.

187. See, e.g., E. Brownel, Legal AId in The UNited States 83 (1951); L. SilverSTEIN, DEFENSE OF THE POOR IN CRIMINAL CASES IN AMERICAN STATE COURTS 7-8 (1965); RePort OF THE ATTORNEY GENERAL's COMMTTTEe ON POVERTY AND THE ADMiNISTRAtION Of Federal CRIMINAL Justice 134 (1963); Boskey, The Right to Counsel in Appellate Proceedings, 45 MINN. L. REV. 783 n.1 (1961); Kadish \& Kimball, Legal Representation of the Indigent in Criminal Cases in Utah, 4 UTAH L. Rev. 198, 214 (1954).

188. See, e.g., Brief for Petitioners at 21-25, Griffin v. Illinois, 351 U.S. 12 (1956).

189. 351 U.S. at 33 (Harlan, J., dissenting).

190. D. Wilkes, Post-Conviction Constitutional Rights of Indigent Criminal Defendants: State Interpretation of Griffin v. Illinois, apps. I \& II, at 1-20, 21-23, 26-28 (Inst. of Jud. Ad.) (July 1959). 
move this severe obstacle to effective appellate review of many convictions. Five years later no evidence existed of any deviation from Griffin. ${ }^{191}$

As for counsel on appeal, in 1959 no more than fourteen states required the appointment of a lawyer for indigents on "the first appeal, granted as a matter of right . . . from a criminal conviction." 192 Among the remainder, some states appointed appellate counsel for indigents only in capital cases; others left the matter to the discretion of the reviewing court, the trial judge, or the trial lawyer (if there was one); in yet others the practice varied from county to county. Even in the fourteen states that did regularly assign counsel, some limited the practice to felony cases and at least five ${ }^{193}$ formulated their rules only in response to their prescient reading of the Griffin rationale. ${ }^{194}$ However, an extensive nationwide audit conducted just a few months after Douglas found that "nearly all the sample counties had some system for providing counsel for appeals,"195 thus affording what few lawyers or laymen would dispute to be a normally indispensable ingredient for successful appellate review.

\section{Line-ups}

Before 1966, there was no comprehensive data regarding the extent to which the police afforded persons accused of crime the right to counsel or other procedural safeguards at pretrial identification proceedings. But "law enforcement officials of the Federal Government and of all 50 states . . . [had] proceeded on the premise that the Constitution did not require the presence of counsel at pretrial confrontations for identification" and "no court [had] announced such a requirement"196 prior to a Fifth Circuit ruling in that year, ${ }^{197}$ which the Supreme Court approved in United States $v$. Wade ${ }^{198}$ and reaffirmed in Gilbert v. California. ${ }^{199}$ Although "the Court quite obvi-

191. L. SILVERSTEIN, supra note 187, at 139. States that changed their position within threc years included Colorado, Connecticut, Delaware, Illinois, Kansas, Maine, Maryland, Massachusetts, Minnesota, New Jersey, Texas, Washington, and West Virginia.

192. Douglas v. California, 372 U.S. at 356 (emphasis omitted). In Ross v. Moffitt, 417 U.S 600 (1974), the Court declined to extend the Douglas principle to discretionary state appeals or to applications for review in the United States Supreme Court.

193. D. Wilkes, supra note 190, app. I, at 7 (Md.), 8 (Mass.), 15 (Or.), 16 (S.D.), 18 (Va.).

194. $I d$.

195. L. SIL VERSTEIN, supra note 187, at 139.

196. Stovall v. Denno, 388 U.S. 293, 299 (1967).

197. Wade v. United States, 358 F.2d 557 (5th Cir. 1966), vacated on other grounds, 388 U.S. 218 (1967).

198. 388 U.S. 218 (1967).

199. 388 U.S. 263 (1967). 
ously [did] not have before it any reliable, comprehensive survey of current police practices on which to base its new rule,"200 the array of unfairly suggestive police identification procedures sifted by the Court from reported state cases is striking ${ }^{201}$ and tends to confirm the view that "the influence of improper suggestion upon identifying witnesses probably accounts for more miscarriages of justice than any other single factor."202

The response to the Wade-Gilbert dictate was impressive. A survey of forty-seven police departments across the country, carried out three years after the decisions, showed that all had promulgated regulations governing the conduct of pretrial identification practices. ${ }^{203}$ Every police department in the study "indicated that if a suspect desires the presence of counsel at a lineup . . . but does not have his own attorney, there is an established procedure for providing the suspect with counsel."204 Although the great majority of police regulations limited the lawyer's role to that of an observer, ${ }^{205}$ some went beyond this minimum requirement of the Court's holding by allowing counsel to proffer suggestions concerning the conduct of the lineup and even to question witnesses. ${ }^{206}{ }^{\circ}$

Wade and Gilbert, of course, do not complete the story of police identification practices. A survey of several metropolitan police departments suggested that one result of the Wade and Gilbert decisions was the greater use of photographic displays instead of lineups, ${ }^{207}$ and in United States v. Ash, ${ }^{208}$ the Court held that photographic displays,

200. 388 U.S. at 252 (White, J., dissenting).

201. 388 U.S. at 232-34.

202. P. Wall, Eye-Witness Identification in Criminal Cases 26 (1965); see also E. BORCHARD, CONVICTING THE INNOCENT Xiii, 1-6 (1932).

203. Note, Protection of the Accused at Police Lineups, 6 Colum. J. L. \& Soc. Prons. 345, 347 n.7 (1970). In cities such as Buffalo, New Orleans, New York and Pittsburgh, police rules required that "[t] he subject shall be advised that he is going to be viewed by others for the purpose of establishing his identity . . . and . . . that he is entitled to have an attorney present during such proceeding . . . ." Id. at 360 (quoting N.Y. Police Dept. Reg., Police Line-up for Identification (July 26, 1967)); see also Comment, Right to Counsel at Police Identification Proceedings, 29 U. PITT. L. REv. 65, $79-83$ (1967) (discussing police practices in Pittsburgh).

204. Note, supra note 203, at 361 . Indeed, a few departments - such as Denver and Toledo - even forbade waiver by the accused, at least in "felony cases of major importance." See id. at 362 (quoting Denver Police Dept. Regs., Lineups (undated) (disallowing use of lineups "unless an attorney, other than a District Attorney, be present")); id. at 363 (quoting Toledo Police Dept. Gen. Order No. 231, Right to Presence of Counsel When Confronted by Witness (June 28, 1967) (forbidding waiver of the right to counsel at lineups by the accused, at least in "felony cases of major importance")).

205. Note, supra note 203, at 363.

206. Id. at 366.

207. Steele, Kirby v. Illinois: Counsel at Lineups, 9 CRIM. L. BuLL. 49, 53 (1973).

208. 413 U.S. 300 (1973). 
in contrast to lineups, were not subject to the sixth amendment right to counsel. ${ }^{209}$ Further, in Kirby v. Illinois, ${ }^{210}$ the Court restricted the Wade-Gilbert protection to those lineups conducted after formal charges were filed against the accused. As a consequence, although a majority of the courts that had addressed the question between Wade and Kirby had found the distinction announced in Kirby unpersuasive, ${ }^{211}$ most post-Kirby decisions adopted its limitation. ${ }^{212}$ Some state courts, however, disregarded Kirby's circumscription of individual rights and applied the Wade-Gilbert safeguard to virtually all postarrest lineups. ${ }^{213}$

Yet stronger evidence of the libertarian impact of the Court's decisions may be found in the fact that, despite Kirby, the practice of many police departments of affording counsel at all lineups, irrespective of whether or not formal charges have been filed, remained unchanged.214 Moreover, even if counsel is not present at the lineup, several empirical surveys disclose that the Wade ruling "stimulated new efforts" to devise lineup norms to eliminate "the most obvious forms of abusive practice. For example, they typically advise that lineup participants be of generally the same age, sex, height, weight and race, and some stipulate that they must wear similar clothing."215 Finally, for identification procedures without counsel, "the most significant factor will be the retention of a record that permits counsel at

209. But cf. In re W.C., 85 N.J. 218, 426 A.2d 50 (1981) (defendant may have right to pretrial lineup); Commonwealth v. Sexton, 485 Pa. 17, 400 A.2d 1289 (1979) (same).

210. 406 U.S. 682 (1972).

211. See Note, Right to Counsel at Lineups - A Pro Forma Right?, 7 SUFfolk U. L. REv. 587, 599 (1973).

212. See Note, The State Responses to Kirby v. United States, 1975 WASH. U. L.Q. 423, 437 38; see also Lomax v. Alabama, 629 F.2d 413 (5th Cir. 1980), cert. denied, 450 U.S. 1002 (1981); People v. Hawkins, 55 N.Y.2d 474, 487, 435 N.E.2d 376, 382-83, 450 N.Y.S.2d 159, 165, cert. denied, 459 U.S. 846 (1982); State v. Henderson, 285 N.C. 1, 10, 203 S.E.2d 10, 17 (1974), vacated on other grounds, 428 U.S. 902 (1976); Wyatt v. State, 566 S.W.2d 597 (Tex. Crim. App. 1978).

213. Blue v. State, 558 P.2d 636 (Alaska 1977); People v. Bustamante, 30 Cal. 3d 88, 634 P.2d 927, 177 Cal. Rptr. 576 (1981); People v. Jackson, 391 Mich. 323, 217 N.W.2d 22 (1974); Commonwealth v. Richman, $458 \mathrm{~Pa}$. 167, 320 A.2d 351 (1974); $c f$. State v. Thomas, 406 So. 2d 1325,1328 (La. 198i) (state statutory right to counsel broader than federal constitutional right). Michigan went beyond these courts by requiring counsel for an accused in custody at post-arrest photographic displays as well. People v. Anderson, 389 Mich. 155, 171, 186-87, 205 N.W. 2d $461,467,476$ (1973).

214. In a study of nine metropolitan police departments on the effect of Kirby, six advised that they would continue to conduct their lineups according to the procedures devised after the Wade case. The other three departments advised that they would continue to follow their Wade procedures in most cases; e.g., "We may use Kirby in emergency cases or late at night, but we will continue to use our present procedure in routine cases."

Steele, supra note 208, at 57 n.38.

215. Levine \& Tapp, The Psychology of Criminal Identification: The Gap from Wade to Kirby, 121 U. PA. L. REV. 1079, 1084 (1973). 
trial to reconstruct the lineup and call the jurors' attention to elements of suggestiveness, and that record commonly is available under the new regulations."216

\section{Jury Trial}

In a series of decisions in 1968 and 1970, the Court extended the constitutional right of criminal defendants to trial by jury, holding that the sixth amendment guarantee for all crimes authorizing imprisonment for more than six months must be afforded in state criminal cases as well as in federal prosecutions. Prior to Duncan v. Louisiana $a^{217}$ and Baldwin v. New York, ${ }^{218}$ Louisiana granted jury trials only in cases in which death or imprisonment at hard labor could be imposed, thus denying this fundamental safeguard for a great many offenses, including batteries which carried penalties of up to two years. ${ }^{219}$ New Jersey withheld jury trials for disorderly conduct charges which might result in one-year sentences; and New York City provided jury trials only for offenses bearing maximum sentences of more than one year. ${ }^{220}$ As a consequence of the Justices' holdings, these jurisdictions either lowered the penalties for a number of offenses to six months (or less) or provided defendants with a jury trial.221 Although the jurisdictions concerned were few in number, statistics from New York City alone for a thirty-month period in the mid-1960's showed that more than 300,000 cases would have been affected.222

It is more difficult to estimate tie number of criminal contemnors whose rights were secured ${ }^{223}$ by the Court's ruling in Bloom v. Illinois 224 that the right to jury trial applies to any contempt prosecution when a penalty of more than six-months imprisonment is imposed. But a study not long before the decision found that in more than onethird of the states "either no limitation is placed on contempt

216. Israel, Criminal Procedure, the Burger Court, and the Legacy of the Warren Court, 75 Mich. L. Rev. 1319, 1370 n.229 (1977). Compare Bruce v. State, 268 Ind. 180, 263-64, 375 N.E.2d 1042, 1086 (no right to counsel at lineup recorded on videotape before formal charges), cert. denied, 439 U.S. 988 (1978), with State v. Gaitor, 388 So. 2d 570, 571 (Fla. Dist. Ct. App. 1980) (counsel required at lineup after formal charges despite videotape).

217. 391 U.S. 145 (1968).

218. 399 U.S. 66 (1970).

219. Duncan, 391 U.S. at 146.

220. 391 U.S. at 161 n.33.

221. Baldwin, 399 U.S. at 71.

222. 399 U.S. at 135 (Harlan, J., dissenting).

223. Cf. Bloom v. Illinois, 391 U.S. 194, 207 n.8 (1968) (state contempt penalties often diffcult to determine).

224. 391 U.S. 194 (1968). 
sentences or the limitation is in excess of six months."225 In the federal courts, data for the fiscal year ending in mid-1962 revealed that of twenty-one contemnors committed to prison, "[s]entences of eight of these prisoners exceeded six months; three prisoners had sentences exceeding one year, and of these two prisoners had sentences of two years or more."226 Moreover, other evidence suggested a substantial increase in more recent years in the use of summary punishment and severe penalties for criminal contempt. 227

The significance for personal liberty of the constitutional right to jury trial may be gleaned from several sources. In the years 19731977 , between fifty-four and sixty-one percent of all criminal defendants who went to trial in the federal court system chose to entrust a judgment to a jury. ${ }^{228}$ These figures must take into account the fact that because of various considerations - e.g., the type of offense, the accused's prior record, fear of community prejudice, and the nature of the major defense - there is often an informed expectation of a lesser sentence after a bench trial. ${ }^{229}$ When these special circumstances are not present, however, careful empirical research discloses that juries are substantially more sympathetic to defendants than judges in respect to such vital matters as conviction or acquittal and harshness of penalty. ${ }^{230}$

It is true that not all of the Court's decisions in this area have favored the right to jury trial. Indeed, there is impressive evidence that the rulings in Apodaca v. Oregon, ${ }^{231}$ which upheld nonunanimous

225. Note, Constitutional Law: The Supreme Court Constructs a Limited Right to Trial by Jury for Federal Criminal Contemnors, 1967 Duke L.J. 632, 655 n.84. In New Jersey, for example, sentences would run for as long as three years. Id.

226. Cheff v. Schnackenberg, 384 U.S. 373, 385 n.3 (1966) (Douglas, J., dissenting).

227. See Hilts, The Increasing Use of the Power of Contempt, 32 MoNT. L. REv. 183, 185 (1971); Note, Contempt of Court, 7 SuFFolk U. L. REv. 517, 519 (1973). Although there appeared to be no recorded case before 1914 involving a sentence of greater than one year, see United States v. Green, 241 F.2d 631, 634 (2d Cir. 1957), affd., 356 U.S. 165 (1958), a 1971 Pennsylvania decision presented a sentence of up to 22 years for criminal contempt, see Mayberry Appeal (Commonwealth v. Langnes), 434 Pa. 478, 480-81, 255 A.2d 131, 132-33 (1969), vacated sub nom. Mayberry v. Pennsylvania, 400 U.S. 455 (1971).

228. ADMinistrative OFFICE OF U.S. COURTS, 1977 JUROR UTILIZATION IN U.S. DisTRICT COURTS (1978) (foldout $\varepsilon$ ttached to back cover).

229. See H. KALVEN \& H. ZeISEI, ThE AMERICAN JURY 26-30 (1966).

230. See $i d$ at 58-62. To cite one illustration, in response to questionnaires submitted by Kalven and Zeisel "to 550 judges across the country with reference to 3,576 jury trials over which they had presided. . . . [t] $]$ he judges agreed with the juries 75 per cent of the time. In the other 25 per cent, the juries were primarily more lenient than the judges would have been." $M$. BlOOMSTEIN, Verdict: THE JURY SYSTEM 134 (rev. ed. 1972) (summarizing the Kalven and Zeisel study).

231. 406 U.S. 404 (1972); see also Johnson v. Louisiana, 406 U.S. 356 (1972) (less-thanunanimous jury verdict does not violate due process or equal protection). 
jury verdicts, and, especially, Williams $v$. Florida, ${ }^{232}$ which permitted juries containing as few as six persons, have markedly diminished the protections afforded the accused by peer judgment. Empirical data suggest that smaller juries are not as representative of the community; are less likely to recall important evidence, make accurate fact-findings, or engage in effective group deliberation; are less inclined to deadlock and therefore more likely to reach "extreme compromises" and render "incorrect" decisions; and, ultimately, more likely to convict defendants - indeed, more likely to convict innocent defendants. ${ }^{233}$

These adverse effects have been somewhat ameliorated, however, by the Justices' most recent pronouncements in Ballew v. Georgia, ${ }^{234}$ rejecting the use of only five jurors, and in Burch v. Louisiana, ${ }^{235}$ invalidating a rule permitting nonunanimous verdicts by a six-person jury. Overall, it must be fairly concluded that the Court's product on jury trials has advanced the individual rights of those accused of crime.

\section{Self-Incrimination}

In Griffin v. California, ${ }^{236}$ the Court disapproved the rule of six states $^{237}$ that permitted the trial judge, and in some instances the prosecutor, in a criminal case to make adverse comments to the jury on the accused's failure to testify in his own defense. The extent to which this practice impaired the constitutional right against self-incrimination is incapable of precise verification. But common sense persuasively suggests that the possibility of damaging comments on the defendant's silence confronted him with a troublesome dilemma: it would either exacerbate the inference of guilt that most jurors draw from the defendant's not taking the stand, ${ }^{238}$ or it would force him to testify despite the attendant dangers that the self-incrimination privilege meant to avoid. As the Court long ago recognized,

It is not every one who can safely venture on the witness stand though entirely innocent of the charge against him. Excessive timidity, nervousness when facing others and attempting to explain transactions of a sus-

232. 399 U.S. 78 (1970).

233. See Ballew v. Georgia, 435 U.S. 223, 230-43 (1978), and authorities cited therein; see also Zeisel, The Waning of the American Jury, 58 A.B.A. J. 367 (1972) (questioning the Supreme Court's decision to allow six-person juries).

234. 435 U.S. 223 (1978).

235. 441 U.S. 130 (1979).

236. 380 U.S. 609 (1965).

237. Griffin, 380 U.S. at 611-12 n.3 (California, Connecticut, Iowa, New Jersey, New Mexico and Ohio).

238. Note, To Take the Stand or Not to Take the Stand: The Dilemma of the Defendant with a Criminal Record, 4 ColUM. J, L. \& Soc. PROBS. 215, 221 n.47 (1968). 
picious character, and offences charged against him, will often confuse and embarrass him to such a degree as to increase, rather than remove prejudices against him. ${ }^{239}$

The pressures on criminal defendants to forgo their constitutional right of silence were recently mitigated even further in Carter $\gamma_{\text {. Ken- }}$ tucky, ${ }^{240}$ in which the Court rejected the practice of at least five states $^{241}$ of refusing to have the trial judge instruct the jury against making biased assumptions about the accused's decision not to take the stand.

\section{Cruel and Unusual Punishment}

At the time of the Court's decision in Robinson v. California, ${ }^{242}$ which held that it was cruel and unusual punishment to make narcotic addiction a criminal offense, approximately one-third of the states did so, with the penalty ranging up to five years imprisonment. ${ }^{243}$ Although many states had also authorized civil commitment of narcotic addicts, ${ }^{244}$ most "failed to provide even the minimum facilities required"245 for treatment.

Obviously, Robinson has solved neither society's drug problems nor the plight of its victims. Indeed, Robinson notwithstanding, "possession" of narcotics may still be made criminally punishable, ${ }^{246}$ so most addicts continue to run a serious risk of penal incarceration. ${ }^{247}$ Further, to the extent that compulsory civil commitment, which was approved in Robinson, either fails to afford addicts a reasonable chance of cure or results in prolonged confinement not dissimilar to imprisonment under criminal conviction, ${ }^{248}$ it may be said that Robin-

239. Wilson v. United States, 149 U.S. 60, 66 (1893). Among the "costs of testifying," for the innocent as well as the guilty, are "the defendant's unconvincing demeanor, confusion, or faulty memory as to details of his story, and especially, the fear that he will be impeached with prior convictions." Bradley, Griffin v. California: Still Viable After All These Years, 79 MiCH. L. REV. 1290, 1294 (1981):

240. 450 U.S. 288 (1981).

241. 450 U.S. at 290 n.2 (Kentucky, Minnesota, Nevada, Oklahoma and Wyoming).

242. 370 U.S. 660 (1962).

243. See Laws Controlling Illicit Narcotics Traffic, S. Doc. No. 120, 84th Cong., 2d Sess. 41 (1956) [hereinafter cited as S. Doc. No. 120].

244. See F. Lindman \& D. McInTYRe, The Mentally Disabled and the LAw 87.88 (1961).

245. S. Doc. No. 120, supra note 243, at 45; see also Aronowitz, Civil Commitment of Narcotic Addicts, 67 Colum. L. REv. 405, 406 (1967); Note, Civil Commitment of Narcotic Addicts, 76 YALE L.J. 1160, 1164 (1967).

246. See Note, Punishment of Narcotics Addicts for Possession: A Cruel But Usual Punishment, 56 IowA L. REV. 578, 586 (1971).

247. See King, Narcotic Drug Laws and Enforcement Policy, 22 LAw \& CoNTEMP. ProBs. 113, 130-31 (1957).

248. Early data contradicted neither premise. See generally Kramer, The State Versus the 
son has accomplished little for civil liberty.

But the record is not so one-sided. Spurred at least in part by the Court's ruling in Robinson, ${ }^{249}$ both California and New York (where estimates placed nearly two-thirds of the country's narcotics addicts), ${ }^{250}$ followed by Congress, enacted new civil commitment programs that for the first time attempted large scale treatment with the "hope to succeed where previous efforts have notoriously failed."251 The rehabilitation success rate of these plans has apparently been modest at best, ${ }^{252}$ with California statistics between 1967 and 1973 showing a somewhat steadily decreasing percentage of persons placed on outpatient status who are returned within five years with a new civil narcotic commitment. ${ }^{253}$ Moreover, although questions have been raised about their methodology, ${ }^{254}$ several studies have shown a dramatic reduction in overall arrest rates during methadone maintenance treatment. ${ }^{255}$ Further, it has been held that the state's failure to provide minimal treatment to persons who have been institutionalized involuntarily is grounds for release. ${ }^{256}$

Addict: Uncivil Commitment, 50 B.U. L. REv. 1 (1970); Aronowitz, supra note 245; Note, supra note 245 , at 1162-63. But see text at note 257 infra.

249. See Aronowitz, supra note 245, at 410-11; Note, supra note 245, at 1160.

250. Departments of Treasury and Post Office and Executive Office of the President Appropriations for 1968: Hearings Before a Subcomm. of the House Comm. on Appropriations, 90th Cong., lst Sess. 417 (1967).

251. Note, supra note 245 , at 1162 .

252. See generally Kramer, supra note 248; Aronowitz, supra note 245.

253. See Cal. Rehabilitation Center Program, Summary Statistics: Civil ComMITMENT Program for NARcotic ADDICTS 63-66 (1972); see also Wood, 18,000 Addicts Later: A Look at California's Civil Addict Program, FED. PROBATION, Mar. 1973, at 26, 31 (nearly half of all persons released from California Rehabilitation Center pursuant to special program "have remained in the community for over 1 year" and "less than 5 percent are returned with new felony commitments"). Most impressive - although perhaps attributable at least in part to changes in the California criminal sentencing law - is the percentage of male narcotic addicts in California who are returned each year to rehabilitation centers with new civil narcotics commitments as compared to the total number of outpatients. From a high of $5.6 \%$ in 1967 , the figure has consistently diminished to an average of $1.5 \%$ in the years 1978-1980. Computer Printout from California Department of Corrections, to author, as of Dec. 29, 1981 (1967 $-5.6 \%, 1968-4.5 \%, 1969-4.9 \%, 1970-3.4 \%, 1971-3.7 \%, 1972-3.5 \%, 1973-$ $3 \%, 1974-2.9 \%, 1975-2.8 \%, 1976-2.7 \%, 1977-1.7 \%, 1978-1.6 \%, 1979-1.3 \%$, $1980-1.7 \%)$.

254. Greenberg \& Alder, Crime and Addiction: An Empirical Analysis of the Literature, 1920-73, 3 Contemp. Drug Prob. 221, 248-60 (1974).

255. Cushman, Relationship Between Narcotic Addiction and Crime, Fed. Probation, Sept. 1974, at 38, 43; see also Joseph, A Probation Department Treats Heroin Addicts, Fed. Probation, Mar. 1973, at 35, 38-39.

256. Cf., e.g., Rouse v. Cameron, 373 F.2d 451 (D.C. Cir. 1966) (petitioner committed to mental hospital upon acquittal by reason of insanity has right to adequate treatment, which if not rendered may entitle petitioner to be released); Welsch v. Likins, 373 F. Supp. 487 (D. Minn. 1974) (civil commitment for mental retardation must be accompanied by minimally adequate treatment); Wyatt v. Stickney, 344 F. Supp. 387 (M.D. Ala. 1972) (civilly committed mental patients have a right to treatment), affd. in part \& revd. in part, 503 F.2d 1305 (5th Cir. 1974). 
Finally, at the very least, some meaningful indication of Robinson's impact on personal rights may be gleaned from the attitudes of those subject to it: in a survey of persons who had been involuntarily confined in California, most of those "who had been convicted of a felony narcotics violation prior to their civil commitment (about $75 \%$ of the population) feel that they are better off serving time in the civil commitment program than in a prison."257

\section{Commitment of Mentally Ill}

The Court's 1966 decision in Baxstrom v. Herold 258 apparently affected persons confined in mental facilities only in the state of New York and has gone "virtually unnoticed by legal scholars."259 In Baxstrom, the Court held that New York's statutory procedures for civilly committing persons at the expiration of their prison sentence violated equal protection because only this class was denied "the right to de novo review by jury trial of the question of their sanity,"260 and only this class could be committed to the two institutions maintained by the Department of Correction (rather than the twenty-one operated by the Department of Mental Hygiene) ${ }^{261}$ without a judicial determination that they were "dangerously mentally ill." 262

Within little more than six months of the Justices' edict, 992 patients were transferred - pursuant to an administrative process dubbed "Operation Baxstrom" - from the Department of Correction facilities at Dannemora and Matteawan to Department of Mental Hygiene institutions. ${ }^{263}$ The consequences for those transferred were substantial: the Court in Baxstrom observed the "striking ... dissimilarities" between the types of institutions ${ }^{264}$ and the respondents referred to the "environment of loose security and relaxed obser-

257. Kramer, supra note 248 , at $12-13$. This may be due largely to the fact that, at the time, the potential period of incarceration was shorter. Id. at 13.

258. 383 U.S. 107 (1966).

259. Morris, The Confusion of Confinement Syndrome: An Analysis of the Confinement of Mentally Ill Criminals and Ex-Criminals by the Department of Correction of the State of New York, 17 Buffalo L. REv. 651, 665 (1968); see Baxstrom, 383 U.S. at 110-11, 114.

260. 383 U.S. at 111.

261. Brief for Petitioner at 8, Baxstrom v. Herold, 383 U.S. 107 (1966).

262. 383 U.S. at 110.

263. Morris, supra note 259 , at 655,671 . This included 136 of the 210 inmates who had been held in Matteawan on the basis of an administrative determination that they were "too dangerously mentally ill to be in civil hospitals." Id. at 671, 674. "Unless overnight 136 dangerous mental patients were miraculously cured of their dangerousness, it may be safely assumed that 62 per cent of the patients confined in Matteawan pursuant to [this criterion] were not, in fact, dangerous." Id. at 674.

264. 383 U.S. at 113 . 
vation" in the facilities for the civilly insane. ${ }^{265}$ More specifically, the median period of confinement at Matteawan had been between six and seven years (with nearly twenty percent of the residents being incarcerated twenty years or more) as compared to a four-month average length of hospitalization at the Department of Mental Hygiene units. ${ }^{266}$

The dispositions of the 992 people moved to civil mental hospitals is even more telling. Within a little more than six months, seventynine were discharged, twenty-two were conditionally released on convalescent care, twenty-four became "informal" patients (free to go at any time), 273 were retained on "voluntary" status (able to leave within ten days after written request), and an additional forty-two had departed on other statuses. Only six were re-transferred to Matteawan as dangerously mentally ill. 267

Finally, the Court's decision in Baxstrom had an indirect, albeit extremely significant effect relating to psychiatric predictions of dangerousness. As a result of the Justices' edict, the State of New York appropriated funds for long-term studies of the patients released or transferred. ${ }^{268}$ These inquiries found a startlingly low rate of postrelease dangerous offenses, and triggered a rash of further studies and articles critically assessing the ability of psychiatrists to predict "dangerousness." 269 If this succeeds in lessening courts' traditional reliance on these predictions (e.g., in respect to civil commitments, release of the insane, etc.) the impact on the individual rights of those subject to such predictions promises to be enormous. ${ }^{270}$

265. Brief for Respondent at 7, Baxstrom v. Herold, 383 U.S. 107 (1966).

266. Morris, supra note 259, at 656 . In 1965 ,

there were 255 patients at Matteawan whose sentences had expired. The median period of confinement of this group was 9 years. To that 9 years must be added the time spent in Matteawan prior to the expiration of their sentences.

Fifty-four other ex-criminal patients had been transferred to Matteawan from civil state hospitals. The median period of confinement of this group was 10 years.

Id. at 657 (emphasis in original) (footnotes omitted).

267. Id. at 672-73. The tale of Johnnie K. Baxstrom is illustrative. Sentenced to two-andone-half to three years for second degree assault, he was certified as insane by a prison doctor and sent to Dannemora where he was retained for over four years after his penal sentence expired. Baxstrom, 383 U.S. at 108-09. Pursuant to "Operation Baxstrom," he was transferred to a civil hospital and, after requesting review of his retention, was discharged three months after the Court's decision when a jury found him not mentally ill. Morris, supra note 259, at 670 n.131.

268. See, e.g., Steadman \& Keveles, The Community Adjustment and Criminal Activity of the Baxstrom Patients: 1966-1970, 129 AM. J. Psychiatry 304 (1972).

269. See, e.g., Diamond, The Psychiatric Prediction of Dangerousness, 123 U. PA. L. REv. 439, $445-47$ (1974).

270. For a possible harbinger of such change, see Estelle v. Smith, 451 U.S. 454, 472 (1981) (noting criticism of psychiatric predictions of dangerousness). 


\section{Juveniles}

In the mid-1960's, it was reported that persons under eighteen years old accounted for more than twenty percent of arrests for serious crimes and for more than fifty percent of arrests for serious property offenses. ${ }^{271}$ In 1967, the year of the Supreme Court's landmark decision in In re Gault, ${ }^{272} 811,000$ cases concerning allegedly delinquent youths were disposed of in juvenile courts ${ }^{273}$ and some 84,000 children were committed to juvenile institutions (public training schools and forestry camps). ${ }^{274}$ By 1976, the juvenile courts were handling about 1.4 million delinquency cases annually, a substantial increase from 1967.275 The number of minors potentially affected by the fairness of juvenile court procedures is immense.

It is true that, in the two decades prior to Gault, marked progress had been made to afford "a greater measure of procedural regularity in the juvenile courts."276 of most far-reaching significance, in the early 1960's, three major states, California, New York and Illinois, promulgated new juvenile court acts ${ }^{277}$ which went a considerable distance in anticipating the Supreme Court's ruling. ${ }^{278} \mathrm{But}$, as will become clear, these developments cannot "overshadow the revolutionary dimensions of the Gault decision,"279 which established and delineated the scope of four constitutional rights for a child at juvenile court proceedings in which he might be adjudged "a 'delinquent' as a result of alleged misconduct on his part, with the consequence that he may be committed to a state institution." 280

First, the child (and his parents or guardian) must have written

271. In re Gault, 387 U.S. 1, 20 n.26 (1967).

272. 387 U.S. 1 (1967).

273. Approximately 382,000 of these cases were resolved judicially and approximately 429,000 were disposed of nonjudicially. J. CORBETT \& T. VEREB, JUVENILE COURT STATISTICS 1974, 15, 17.

274. Ferster, Courtless \& Snethen, The Juvenile Justice System: In Search of the Role of Counsel, 39 ForDHAM L. REV. 375, 400 n.141 (1971) [hereinafter cited as Ferster]. The average length of stay was about ten months in training schools and about six months in forestry camps. Id. at 400 n. 142 .

275. U.S. BuREaU of THE CENSUS, U.S. Dept. of Commerce, STATISTTCAL Abstract of THE UNITED STATES: 1980, at 199 (table 340) (101st ed. 1980).

276. Task Force on Juvenile Delinguency, President's Commn. on law ENForCeMENT AND ADMIN. OF JUSTICE, TASK FORCE REPORT: JUVENILE DELINQUENCY AND YOUTH CRIME 29 (1967).

277. Cal. Welfare \& Institutions Code $\$ \$ 500-87$ (1961) (repealed 1976); N.Y. Family Court Act (1962); Ill. Rev. Stat. ch. 37, $\S 701$ et seq. (1966).

278. See Platt \& Friedman, The Limits of Advocacy: Occupational Hazards in Juvenile Court, 116 U. PA. L. REv. 1156, 1163 (1968).

279. Lefstein, Stapleton \& Teitelbaum, In Search of Juvenile Justice: Gault and Its Implementation, 3 LAW \& SOCY. REv. 491, 559 (1969) [hereinafter cited as Lefstein].

280. 387 U.S. at 13. 
notice "of the specific charge or factual allegations to be considered at the hearing . . . ." This notice "must be given sufficiently in advance of scheduled court proceedings so that reasonable opportunity to prepare will be afforded, and it must 'set forth the alleged misconduct with particularity." "281 Prior to Gault, most states considered juvenile proceedings to be "civil" rather than "criminal" and thus "not subject to the requirements which restrict the state when it seeks to deprive a person of his liberty."282 As a consequence, courts had held either that alleged delinquents had no constitutional right to adequate notice ${ }^{283}$ or, more frequently, that the information afforded need be less than for adults accused of crime. ${ }^{284}$ Thus, in 1949, the eminent sociologist Paul Tappan found that "[a]n almost universal handicap of the child is his ignorance of the meaning of the charge and of his rights in court; rarely is he appraised fully and intelligibly so as to remove his childish misunderstanding and fears."285

Although, as we shall see, compliance with all of Gault's mandates has been far less than perfect, available evidence strongly implies nearly full conformity with the requirement of adequate notice. A survey conducted in the early 1970 's by about 3,000 members of the National Council of Jewish Women in thirty-five jurisdictions reported that "[i]n almost all courts, children and their families are given notice of charges." 286

Second, Gault held that "the child and his parents must be notified of the child's right to be represented by counsel retained by them, or if they are unable to afford counsel, that counsel will be appointed to represent the child."287 At the time of the Court's opinion, about onethird of the states made some provision - by legislation, court rule or

281. 387 U.S. at 33.

282. 387 U.S. at 17.

283. See, e.g., Cinque v. Boyd, 99 Conn. 70, 121 A. 678 (1923) (state may act without any process restrictions to take custody of child).

284. See, e.g., Application of Gault, 99 Ariz. 181, 407 P.2d 760 (1965); Rose v. State, 137 Tex. Crim. 316, 129 S.W.2d 639 (1939); see also Clark, Juvenile Delinquency in Colorado: The Law's Response to Society's Need, 31 Rocky MTN. L. REv. 1, 10-11 (1958).

285. P. TAPPAN, JUVENILE DelinquenCy 184 (1949).

286. E. Wakin, Children Without Justice: A Report by the National Council OF JEWISH WOMEN 68 (1975). As a more specific example, in Ohio "the officers of the Juvenile Court Judges Association, immediately after Gault, gave warning to all Ohio judges that a statute "which set forth that a complaint is sufficiently definite which merely alleges the child to be delinquent is no longer valid.'" Paulsen, Juvenile Courts and the Legacy of '67, 43 IND. L.J. 527, 540 (1968). Subsequent interviews with officials of eight juvenile courts in the state disclosed that there had been " $a$ 'tightening up' of procedural safeguards in delinquent cases" - charges were now being made with greater particularity; notices were now being forwarded to parents with the summons; parents were now being given adequate time to prepare. Reckless \& Reckless, The Initial Impact of the Gault Decision in Ohio, 18 JUV. CT. JUDGES J. 121-22 (1968).

287. 387 U.S. at 41 . 
practice - for counsel in juvenile delinquency proceedings. ${ }^{288}$ Nationwide, statutes and judicial decisions were sharply divided. ${ }^{289}$ Moreover, two widely cited empirical studies revealed that counsel appeared in only a small fraction of juvenile delinquency adjudications. ${ }^{290}$ "Taken together these two surveys suggested that not only was the frequency of defense counsel involvement dismally low in most big-city courts in the years immediately prior to the Gault decision, but that this condition was uniform throughout our major cities and was not improving."291

The meager incidence of representation for alleged delinquents also contributed to the uneven provision of the third and fourth constitutional liberties recognized in Gault: the right to confront and crossexamine witnesses, ${ }^{292}$ and the right to be advised of the privilege against self-incrimination. ${ }^{293}$ As a matter of law, some courts, relying on the rationale that juvenile proceedings were "non-criminal," held that there was no guarantee of confrontation and permitted findings of

288. 387 U.S. at $37-38$.

289. Some laws accorded only a right to retained counsel; a few guaranteed appointed counsel for indigents, at least on request; others left appointment of a lawyer to the court's discretion. In states with no statutory provisions, courts split on whether or not there was a right to retain an attorney, but few guaranteed assignment of counsel for the poor. See the citations collected in Lefstein, supra note 279, at 492 n.2; Antieau, Constitutional Rights in Juvenile Courts, 46 CoRNELL L. Q. 387, 404-07 (1961).

290. In 1963, in a survey of juvenile court judges sitting in the nation's 75 largest cities (representing 37 states), $59 \%$ reported that youthful offenders were represented by a lawyer in less than $5 \%$ of all delinquency proceedings, and in $81 \%$ of the courts, minors had attorneys in less than $10 \%$ of the cases; only $4 \%$ of the judges responded that counsel appeared in more than half the hearings. Skoler \& Tenney, Attorney Representation in Juvenile Court, 4 J. FAM. L. 77, 81 (1964). When lawyers were present, they "were almost always retained counsel rather than assigned or defender system counsel." Id. at 84. In 1966, in a survey of 207 juvenile courts serving populations of more than $100,000,48 \%$ of those responding (184 courts replied) disclosed that minors had retained counsel, and $77 \%$ reported that minors had assigned counsel, in less than $5 \%$ of the cases; $65 \%$ responded that children had retained counsel, and $74 \%$ revealed that children had assigned counsel, in less than $10 \%$ of the cases; fewer than $4 \%$ of the responding judges reported that retained or appointed counsel appeared in more than $40 \%$ of the hearings. TASK FORCE ON JUVENILE DELINQUENCY, supra note 276, at 82 (table 16). Likewise, fewer than $4 \%$ reported that appointed counsel appeared in more than $40 \%$ of the hearings. Id.

291. U.S. Dept. of Justice, Prosecution in the Juvenile Courts: Guidelines for THE FUTURE 15 (1973).

292. 387 U.S. at 56-57.

293. 387 U.S. at 51-55. As observed by the President's Commission on Law Enforcement and Administration of Justice in a report issued just before the Gault decision:

The presence of an independent legal representative of the child, or of his parent, is the keystone of the whole structure of guarantees that a minimum system of procedural justice requires. The rights to confront one's accusers, to cross-examine witnesses, to present evidence and testimony of one's own, to be unaffected by prejudicial and unreliable evidence, to participate meaningfully in the dispositional decision, to take an appeal have substantial meaning for the overwhelming majority of persons brought before the juvenile court only if they are provided with competent lawyers who can invoke those rights effectively.

PREsident's COMMN. ON LAW ENFORCEMENT AND ADMINISTRATION OF JUSTICE, The Chalienge of Crime in a Free Society 86 (1967). 
delinquency to be based on unsworn testimony and hearsay. ${ }^{294}$ Similarly, most courts held the right against self-incrimination inapplicable in juvenile hearings, ${ }^{295}$ and those that ruled otherwise "felt it unnecessary or even inadvisable to inform the minor of this right."296 A common practice was described as follows:

The judge after reading the allegations of the petition to the juvenile will often ask, "did you do it?" or "is this true?" If the youth admits his guilt, the adjudication is complete. If he denies his delinquency, in some jurisdictions the judge will continue to interrogate the child in an effort to determine the veracity of the complaint . . . 297

The state legislative response to the Court's dictates in Gault was impressive. Many states enacted statutes governing some or all of the procedural safeguards announced in Gault. ${ }^{298}$ Of probably greater significance, although the percentage of youths who were in fact represented by counsel at delinquency hearings remained fairly low in a number of juvenile courts, the general increase was dramatic. In 1972, the Boston University Center for Criminal Justice conducted a survey of juvenile court judges in the nation's 100 largest cities. ${ }^{299}$ While "[b]efore Gault only $4 \%$ of . . . [those] cities indicated that more than $50 \%$ of juveniles were represented in delinquency cases," 300 the survey found that in 1972 ,

in $61.8 \%$ of the responding cities, more than $75 \%$ of juveniles in delin-

294. See Antieau, supra note 289, at 401; Lefstein, supra note 279, at 493 n.2; Note, Juvenile Delinquents: The Police, State Courts and Individualized Justice, 79 HARv. L. REV. 775, 794-95 (1966).

295. See Natl. Council on Crime and Delnnquency, Procedure and Evidence in THE JUVENILE COURT 26-27 \& n.6 (1962); Lefstein, supra note 279, at 493 n.2.

296. Lefstein, supra note 279 , at 517.

297. Note, supra note 294 , at 795.

298. For example, within months of the decision, Colorado enacted a new Children's Code explicitly affording the right to retained or assigned counsel and applying the traditional rules of evidence to delinquency hearings. Vermont added provisions governing notice of charges, right to counsel, and the privilege against self-incrimination. Lefstein, supra note 279, at 559 n.184. California, Hawaii, Nebraska, New Hampshire, and New Jersey all established the right to an appointed lawyer for indigent minors either in all proceedings or in proceedings that may result in the commitment of the child. Rubin \& Glen, Developments in Correctional Law, 14 CRIME \& DELINQ. 155, 157 (1968). In the years following Gault, Oklahoma, South Carolina, South Dakota, Virginia and West Virginia followed suit. Glen, Developments in Juvenile and Family Court Law, 5 CRIME \& DELINQ. 295, 299 (1969). And in 1969, "[t]otally new juvenile court acts, or substantial revisions of existing acts" were passed in Connecticut, Kansas, Maryland, North Carolina, North Dakota and Ohio; all dealt "at least minimally with assignment of counsel, specificity of pleadings, and the various evidentiary rights announced in Gault." Glen, Developments in Juvenile and Family Court Law, 16 CRIME \& DelinQ. 198, 198 (1970). In addition, Texas authorized lawyers for poor children. Id. at 201. Shortly after Gault, it was reported that in many areas of the country public or voluntary defender services had been extended to juvenile courts. These sites include Chicago; Cleveland; Denver; Indianapolis; Minneapolis; Montgomery County, Maryland; and Ogden, Utah. Paulsen, supra note 286, at 529-30.

299. See U.S. DEPT. OF JUSTICE, supra note 291, at 16.

300. Id. 
quency cases based upon a felony or serious crime are represented by counsel and that in $47.1 \%$ of these cities, over $75 \%$ of juveniles are represented by counsel in delinquency cases based upon non-felonies or less serious crimes. 301

The extensive National Council of Jewish Women study in the early 1970's found that almost seventy percent of children were automatically assigned counsel and that about fifteen percent were provided a lawyer on request. ${ }^{302}$ Results of surveys conducted in individual states confirm these figures. ${ }^{303}$

Despite the increase in the number of juveniles represented by attorneys, the reports on Gault's implementation in the hustings were not uniformly affirmative. Perhaps the most frequent criticism involved the failure of juvenile court officials to give proper notice and advice concerning the right to counsel. Some jurisdictions promptly devised written forms to comply with both the letter and the spirit of Gault's requirements. ${ }^{304}$ However, observations in several metropolitan juvenile courts of cases in which the alleged offender went unrepresented revealed differential acceptance of the Justices' ruling. ${ }^{305}$ Shortly after Gault, a study was conducted of three major American cities, with populations ranging from just under one million to over

\section{Id.}

302. E. WAKIN, supra note 286 , at 63 .

303. Writing five months after the Gault decision, an observer estimated that in Philadelphia "only about 5 per cent of the children appearing in juvenile court had been represented by counsel in the period immediately preceding 1967 . At present, close to 40 per cent of the children are represented." Coxe, Lawyers in Juvenile Court, 13 CRIME \& DELINQ. 488, 488 (1967) [hereinafter cited as Coxe]. In Ohio, a review of the records of 3,225 juvenile cases in Columbus in the year before and the year after Gault showed that

the overall use of counsel in the post-Gault period (29 per cent of the cases) was more than double the pre-Gault rate (13 per cent) . . . . [This] is especially notable because the right to counsel and to notification of this right had been established by an Ohio statute four years before Gault.

Reasons, Gault: Procedural Change and Substantive Effect, 16 Crime \& DELINQ. 163, 167 (1970). This phenomenon was confirmed by a mail survey in 1967 in which 13 of 47 juvenile court judges or chief probation officers in Ohio replied that delinquent children were more often represented by counsel after Gault. Reckless \& Reckless, supra note 286, at 123. A 1969 study of 67 rural county judges in Kentucky concluded that two-thirds of the courts that had more than half the juveniles represented by lawyers did so "in positive response to Gault." Canon \& Kolson, Rural Compliance with Gault: Kentucky, A Case Study, 10 J. FAM. L. 300, 318 (1971). A statistical analysis in a Tennessee county court, comparing the 14 months prior to Gault with the 35 months immediately thereafter, showed the use of lawyers had more than doubled (from 7\% to 16\%). Langley, The Juvenile Court: The Making of a Delinquent, 7 LAW \& Socy. REv. 273, 286 (tables V, Va) (1972). In Providence, Rhode Island, representatation tripled (from a preGault $5 \%$ to a post-Gault 15\%) and increased tenfold in Portland, Maine (from $2 \%$ to 20\%). D. HorowrTZ, supra note 153, at 185-86. By the mid-1970's, the staff of the Brooklyn, N.Y. Legal Aid Society's Juvenile Rights Division had grown from two or three prior to Gault to 70 attorneys and more than 30 social workers. P. Prescotr, The Child SAvers 75 (1981).

304. See Paulsen, supra note 286, at 531-32.

305. W. Stapleton \& L. Tettelbaum, In Defense of Youth 36 (1972) [hereinafter cited as W. STAPLETON]. 
five million persons. ${ }^{306}$ The cities were given fictitious names: Zenith, Metro, and Gotham, listed in descending order according to population. ${ }^{307}$ The study found that full compliance with Gault was achieved in fifty-six percent of the cases in Zenith. ${ }^{308}$ In Metro and Gotham, however, the written notice that all parents received was incomplete. $^{309}$ Furthermore, in one-third of the cases in Metro and eightyfive percent of those in Gotham, the right to counsel was not mentioned by the judges to those youths appearing without counsel. ${ }^{310}$ In the authors' view, "[i]n virtually all of the other instances, the advice given was insufficient in content to comply with constitutional requirements." 311 In a similar study, undertaken several years after Gault, written notice was afforded to all parents, but only thirty percent of the youths who appeared without lawyers received full oral advice from the judge. ${ }^{312}$ Moreover, evidence from these surveys and other sources indicated that some judges and probation officers not infrequently either directly advised against having a lawyer or indirectly prejudiced the offender's interest in retaining one. ${ }^{313}$

Even granting all these imperfections, Gault's effect in markedly increasing the number of youths represented by counsel stands uncontradicted. Despite the special difficulties and conflicts confronting lawyers in the juvenile court system, ${ }^{314}$ and the criticism that some juvenile court lawyers - especially public defenders ${ }^{315}$ - spent too

306. Lefstein, supra note 279 , at 494.

307. Id.

308. Lefstein, supra note 279 , at 510 .

309. Id. at 506 .

310. Id. at 510; see also W. STAPLEṬON, supra note 305, at 36 (summary of the findings of the Lefstein study).

311. W. STAPleton, supra note 305 , at 36; see also M. BORTNER, INSIDE A JUVENILE COURT 139 (1982) (study of a large metropolitan juvenile court disclosed that the "clarity" with which juveniles were informed of their right to counsel "varies").

312. Ferster, supra note 274 , at 377-80. Furthermore, the authors question the sufficiency of the written notice. Id. at 377.

313. See Lefstein, supra note 279, at 511-16; Ferster, supra note 274, at 378-79; Project, The Lawyer-Child Relationship: A Statistical Analysis, 9 DuQ. L. REV. 627, 637 (1971). Indeed, it has been more recently argued that the "collage of social service agencies which serve the youth of a community but which are not a regular part of the formal juvenile justice system" have diverted many alleged delinquents from the juvenile courts altogether and have thereby caused them to relinquish "voluntarily" all of Gault's procedural guarantees. Streib, The Informal Juvenile Justice System: A Need for Procedural Fairness and Reduced Discretion, 10 JOHN MAR. J. Prac. \& Proc. 41, 52 (1976). At the same time, of course, they also "relinquish" the onus of being committed to an institution for delinquents. See D. HoRowTY, supra note 153, at 204-12.

314. See M. BORTNER, supra note 311, at 136-39.

315. But $c f$. M. BORTNER, supra note 311 , at 137 (arguing that public defenders regularly assigned to juvenile cases are potentially superior juvenile advocates because they are better integrated into the system). 
little time with their clients, ${ }^{316}$ the consequences of greater presence of counsel in the juvenile justice system have been notable. Although a study made just after the Gault decision showed very poor compliance by juvenile judges with the self-incrimination rule in cases in which the offender was unrepresented, ${ }^{317}$ another survey done several years later, which found most youths represented by a lawyer, reported that seventy-five percent of the children had the fifth amendment privilege. ${ }^{318}$

Furthermore, although a pre-Gault study of the impact of lawyers in juvenile court concluded that their "major contribution . . . lay in their ability to mitigate the severity of dispositions rather than disproving allegations of the petitions," ${ }^{319}$ post-Gault data revealed that entry of counsel has significantly increased the number of contested cases $^{320}$ and dismissals. ${ }^{321}$ A parallel study concluded that "there were fewer commitments to institutions and more findings of 'not involved' when the child was represented by counsel." 322 Finally, in Philadelphia, it was reported that increased provision of lawyers dramatically reduced pre-hearing and post-hearing detention of youthful offenders. ${ }^{323}$

316. See E. WAKIN, supra note 286, at 65; Project, supra note 313, at 639; M. BorTNER, supra note 311, at 141; Platt, Schechter \& Tiffany, In Defense of Youth: A Case of the Public Defender in Juvenile Court, 43 IND. L.J. 619, 634 (1968).

317. Lefstein, supra note 279 , at 520-24.

318. E. WAKIN, supra note 286 , at 68 . Indeed, even when no lawyer participated in the proceedings, Gault's confrontation requirement was found to be wholly or partially fulfilled in the large majority of instances. Lefstein, supra note 279, at 524-27.

319. Lemert, The Juvenile Court - Quest and Realities, in TASK FORCE ON JUVENILE DELINQUENCY, supra note 276, at 91, 103. Cf. M. BORTNER, supra note 311, at 139 (juveniles represented by attorney receive more severe dispositions, although they are more likely to be placed on probation).

320. Paulsen, supra note 286, at 531.

321. In Columbus, Ohio, it was discovered "that the proportion of cases dismissed (regardless of representation by counsel) doubled, from 8 per cent (142 out of 1,752 dispositions) to 16 percent $(233$ out of 1,473$)$, undoubtedly a result of the court's greater emphasis upon legal factfinding." Reasons, supra note 303, at 169; see also W. STAPLETON, supra note 305, at 66-67 (indepth empirical study of two metropolitan juvenile courts which found that in one, "attorneys had a profound impact on the outcomes of cases with which they were associated").

322. Ferster, supra note 274, at 402. Similar results were observed in Philadelphia:

Stated bluntly, the presence of lawyers willing to fight for their clients is preventing judges from dumping children into institutions because they don't know what else to do and are too harried or callous to find another solution. It cannot be argued that the reduction is being effected by the the release of children who should really be confined, for re-arrest of those represented by the . . . [legal services] office has been at the unusually low rate of 2.6 percent. (Admittedly the figure for one year's operation is not conclusive.) . . . [I]n the preGault days an average of fewer than two judges per court day disposed of 12,000 cases a year, and it was not uncommon for one judge to "hear" 100 cases in a day.

Coxe, supra note 303, at 493; see also Polow, The Impact of Gault on the Juvenile Process, 20 Juv. CT. JUDGES J. 159 (1969) ("in New Jersey . . . commitments have dropped to less than half the pre-Gault rate.").

323. Coxe reports that

In the past, it was found "necessary" to confine large numbers of children for long periods 
Gault's holding was expressly limited to the four constitutional rights discussed above. But its legacy for individual liberty has stretched much more broadly. Because of the Court's ruling "that the Due Process Clause has a role to play" 324 in juvenile proceedings, lower courts have held that children are also entitled to the sixth amendment right to a speedy trial ${ }^{325}$ and to the fourth amendment right to suppression of illegally seized evidence. ${ }^{326}$ Although Gault left open the applicability of the Miranda rule to questioning of juveniles by police and probation officers, ${ }^{327}$ state statutes ${ }^{328}$ and judicial decisions ${ }^{329}$ have extended this fifth amendment protection to youthful offenders, one jurisdiction going so far as to exclude automatically any confession by a juvenile who did not have the advice of a lawyer. ${ }^{330}$ Despite the Court's conclusion that the sixth amendment right to jury trial is not obligatory in delinquency proceedings, ${ }^{331}$ at least ten states have nonetheless chosen to require it. ${ }^{332}$ Gault found it unnecessary to decide whether due process demands that states give

of time before their hearing, and, despite much official hand-wringing, the situation became worse and worse. Chronic overcrowding of the Youth Study Center became the rule, with an average of fifty-three children sleeping on the gym floor each night. Now, as the result of test cases brought by [legal services] lawyers, the practice of holding children in detention before a court hearing merely upon the authority of a probation officer has been discontinued. Consequently the Youth Study Center is now operating consistently at less than capacity. Also contributing to the depopulation of this facility has been legal action to compel a drastic reduction in post-hearing detention of children - sometimes up to three years pending an opening in an institution providing appropriate treatment. The reduction has been accomplished by legal action to compel the release of children or their admission into other facilities. It is surprising how institutions will do what they "can' $t$ " when they have to.

Coxe, supra note 303 , at $492-93$.

324. Gault, 387 U.S. at 13.

325. See, e.g., Piland v. Clark County Juvenile Court Servs., 85 Nev. 489, 457 P.2d 523 (1969).

326. See, e.g., Ciulla v. State, 434 S.W.2d 948 (Tex. Civ. App. 1968).

327. 387 U.S. at 43 n.74; see also Fare v. Michael C., 442 U.S. 707 (1979) (holding that a juvenile's request to see his probation officer is not a per se invocation of his fifth amendment rights under Miranda).

328. For citation of nine such state provisions, see Harris, Children's Waiver of Miranda Rights and the Supreme Court's Decisions in Parham, Bellotti, and Fare, 10 N.M. L. REV. 379, 396 n.97 (1980).

329. See, e.g., In re Creek, 243 A.2d 49 (D.C. 1968); Freeman v. Wilcox, 119 Ga. App. 325, 167 S.E.2d 163 (1969), modified, Riley v. State, 237 Ga. 124, 226 S.E.2d 922 (1970) (per se exclusionary rule replaced by one that looks at totality of circumstances); Lewis v. State, 259 Ind. 431, 288 N.E.2d 138 (1972); In re Aaron D., 30 A.D.2d 183, 290 N.Y.S.2d 935 (1968); Commonwealth v. Roane, $459 \mathrm{~Pa} .389,329$ A.2d 286 (1974); Leach v. State, 428 S.W.2d 817 (Tex. Civ. App. 1968); State v. Prater, 77 Wash. 2d 526, 463 P.2d 640 (1970) (en banc). See generally Schultz \& Cohen, Isolationism in Juvenile Court Jurisprudence, in PURSUING JUSTICE FOR THE CHILD 20, 25-26 (M. Rosenheim ed. 1976).

330. See, e.g., AlA. CODE § 12-15-67 (1975).

331. McKeiver v. Pennsylvania, 403 U.S. 528 (1971).

332. See Comment, The Right to a Jury Under the Juvenile Justice Act of 1977, 14 GoNZ. L. REV. 401, 421 (1979). 
indigents transcripts of juvenile hearings for purposes of appeal, ${ }^{333}$ but both state legislatures ${ }^{334}$ and judges ${ }^{335}$ have done so.

Finally, although Gault's guarantee of counsel covered only the delinquency adjudication process, ${ }^{336}$ many states routinely expanded this liberty to the disposition stage. 337 Moreover, about one-quarter of the state legislatures, following the pattern of the Uniform Juvenile Court Act, ${ }^{338}$ have guaranteed the right to counsel at "all stages" or "every stage" of juvenile proceedings, ${ }^{339}$ and several states have applied this to such stages as pretrial lineups, ${ }^{340}$ appeals from delinquency adjudications, ${ }^{341}$ and probation revocation hearings. ${ }^{342}$ (Indeed, a majority of the states have gone even further to assure the right of both parents and children to a lawyer at proceedings for termination of parental rights ${ }^{343}$ and a number of courts have extended this to child dependency or neglect hearings. ${ }^{344}$ )

Akin to Brown v. Board of Education, Gault has been hailed as the "keystone" of the rise of a nationwide "children's liberation" movement. ${ }^{345}$ Although the complete impact of the Court's decision has yet to be felt and is ultimately immeasurable, its substantial signifi-

333. 387 U.S. at 58.

334. Glen, Developments in Juvenile and Family Court Law, 16 CrIme \& DeLINQ. 198, 20102 (1970).

335. See, eg., In re Boykin, 39 Ill. 2d 617, 237 N.W.2d 460 (1968); Chambers v. District Court, 261 Iowa 31, 152 N.W.2d 818 (1967); In re Cager, 251 Md. 473, 248 A.2d 384 (1968); In re Karren, 280 Minn. 377, 159 N.W.2d 402 (1968); In re D.L.F., 85 S.D. 44, 176 N.W.2d 486 (1970); see also Paulsen, supra note 286, at 541-42.

336. 387 U.S. at 27 :

337. See Ferster, supra note 274 , at 391.

338. UNIFORM JUVENILE COURT ACT § 26(a) (1968).

339. Clark, Procedural Rights in the Juvenile Court: Incorporation or Due Process?, 7 PEPPERDINE L. REV. 865, 876-77 n.44 (1980).

340. See, e.g., In re Carl T., 1 Cal. App. 3d 344, 81 Cal. Rptr. 655 (1969); In re Holley, 107 R.I. 615, 268 A.2d 723 (1970).

341. See, e.g., Reed v. Duter, 416 F.2d 744 (7th Cir. 1969); In re L.G.T., 216 So. $2 d 54$ (Fla. Dist. Ct. App. 1968); Chambers v. District Court, 261 Iowa 31, 152 N.W.2d 818 (1967).

342. See, e.g., CoLo. REv. STAT. § 19-3-117(3)(b) (1978); see also People ex rel. Guggenheim v. Mucci, 352 N.Y.S.2d 561 (1974) (application of Gault principles to preliminary detention hearings).

343. See Lassiter v. Department of Social Servs., 452 U.S. 18, 30, 34 (1981) (citing cases from Maine, Massachusetts, Nebraska, New Jersey, Ohio, Oklahoma and Washington) (34 jurisdictions statutorily allow for appointment of counsel in termination disputes). Compare Davis v. Page, 618 F.2d 374 (5th Cir. 1980) (holding that parents have a constitutional right to counsel in all dependency proceedings), cert. denied, 104 S. Ct. 735 (1984), with Ex rel. D.B., 385 So. 2 d 83 (Fla. 1980) (holding that counsel is constitutionally required only when the parent is threatened with permanent loss of custody).

344. See Lassiter, 452 U.S. at 30 n.6.

345. See Nationwide Drive for Children's Rights, in THe CHILDREN's RIGHTS MOVEMENT 206 (B. Gross \& R. Gross eds. 1977). 
cance for the advancement of personal liberty has already been plainly confirmed.

\section{Military Justice}

The number of persons actually affected by the series of Supreme Court decisions between 1955 and 1969 denying court-martial authority over various criminal offenses is probably unknowable. But the potential number of defendants thereby removed from the military's jurisdiction was great. During the five years before the ruling in United States ex rel. Toth v. Quarles ${ }^{346}$ - holding that former members of the armed forces could not be court-martialed for crimes allegedly committed while they were in the military - over $3,000,000$ persons had been discharged; ${ }^{347}$ seven years later this figure had increased to over $22,000,000 .{ }^{348}$ At the time of the Court's decisions in 1957 and $1960^{349}$ - withdrawing military jurisdiction over offenses committed abroad by civilian dependents of military personnel and by civilian employees of the armed forces - there were 450,000 such dependents and 25,000 such employees overseas. ${ }^{350}$ In the seven years preceding Reid v. Covert, ${ }^{351}$ a case involving dependents, the army alone had tried 181 civilian dependents by general court-martial and 2,273 by special or summary court-martial for such misdeeds as murder, manslaughter, assault, narcotics and sex offenses, robbery, larceny, forgery, bribery and fraud. ${ }^{352}$ After the Court held in 1969, in O'Callahan v. Parker, ${ }^{353}$ that existing members of the armed services could not be tried in military courts for crimes that were not "serviceconnected," the Army Judge Advocate General estimated that in the prior eighteen years his branch alone had prosecuted 450,000 such cases. $^{354}$

More difficult than approximating the number of people possibly affected by these decisions is determining their real consequences for individual rights. This inquiry turns on where offenders who had been

346. 350 U.S 11 (1955).

347. 350 U.S. at 19.

348. See Warren, The Bill of Rights and the Military, 37 N.Y.U. L. REv. 181, 195 (1962). 349. McElroy v. United States ex rel. Guagliardo, 361 U.S. 281 (1960); Grisham v. Hagan, 361 U.S. 278 (1960); Kinsella v. United States ex rel. Singlețon, 361 U.S. 234 (1960); Reid v. Covert, 354 U.S. 1 (1957).

350. See Warren, supra note 348, at 195.

351. 354 U.S. 1 (1957).

352. Supplemental Brief for Appellant and Petitioner on Rehearing at 30-31, Reid v. Covert, 354 U.S. 1 (1957).

353. 395 U.S 258 (1969).

354. See Nelson \& Westbrook, Court-Martial Jurisdiction Over Servicemen for "Civilian" Offenses: An Analysis of O'Callahan v. Parker, 54 MinN. L. REV. 1, 39 (1969). 
held to be immune to a court-martial will be tried, and the extent to which their personal liberties will be better protected by the alternative.

There are three possibilities. First, if the conduct of an active or former serviceman, or a civilian employee or dependent of the military, is contrary to federal law, then he may be tried in an article III court $^{355}$ - either in the state in which the alleged crime took place or, if committed outside the United States, then "at such place . . . as the Congress may by Law have directed."356 Congress, however, has never established such federal court jurisdiction and, as a result, some alleged offenders (such as Toth and the members of Lieutenant Calley's platoon, who had been discharged before their role in the My Lai massacre was discovered) are not tried at all. ${ }^{357}$ Second, if the purported misdeed takes place within the United States and violates state law, then the defendant may be charged in a state court. This would appear to be the effect of $O^{\prime}$ Callahan-type instances, although there is some evidence that state law enforcers will tend to overlook some acts (e.g., involving drinking or sexual dalliance) that would otherwise be prosecuted harshly by military authorities. ${ }^{358}$ Third, if the misconduct occurs in another country and is a breach of that nation's laws, then the individual may be tried in a foreign court. ${ }^{359}$ This would seem to be the lot of many civilian employees or dependents and of active members of the military who commit nonservice-connected offenses abroad. ${ }^{360}$

On the one hand, it has been forcefully contended that, given the vastly improved quality of military justice, substituting a state trial for a court-martial offers the defendant little advantage, ${ }^{361}$ and that the alternative of being prosecuted criminally in a foreign regime may well put him in an even worse position. ${ }^{362}$ On the other hand, neither the commendation of military procedures nor the disparagement of for-

355. See Toth, 350 U.S. at 21 ; Reid $v$. Covert, 354 U.S. at $48-49$ (Frankfurter, J., concurring). 356. U.S. CONST. art. III, $\S 2$.

357. See W. Generous, Swords and SCAles 176, 224 n.30 (1973).

358. See Bishop, Court Martial Jurisdiction over Military-Civilian Hybrids: Retired Regulars, Reservists, and Discharged Prisoners, 112 U. PA. L. REv. 317, 338-43 (1964).

359. See, e.g., Wilson v. Girard, 354 U.S. 524 (1957).

360. See Mills, O'Callahan Overseas: A Reconsideration of Military Jurisdiction Over Servicemen's Non-Service Related Crimes Committed Abroad, 41 FoRdHAM L. REv. 325, 325 (1972).

361. See, e.g., Moyer, Procedural Rights of the Military Accused: Advantages Over a Civilian Defendant, 22 ME. L. REV. 105 (1970); Nelson \& Westbrook, supra note 354, at 58-61.

362. See, e.g., Reid v. Covert, 354 U.S. at 76 n.12 (Harlan, J., concurring); Everett, O'Callahan v. Parker - Milestone or Millstone in Military Justice?, 1969 DUKE L.J. 853, 866; Moorhead, Reid v. Covert and Its Progeny: The Practical Problem of Punishment, 12 SYRAcuse L. REV. 18, 25 (1960). 
eign justice is unanimous. ${ }^{363}$ In any event, without resolving this dispute, it must be noted that however protective of the rights of the accused the present system of military justice may be, this was not the situation when the Court began confronting the problem in the 1950 's ${ }^{364}$ - although the current reforms were nearly all effectively in place by the time of the O'Callahan ruling in 1969.365 Most important, there is reason to believe that the progress that has been made was stimulated, at least in part, by the Court's pronouncements. ${ }^{366}$

\section{In General}

Finally, apart from the direct effects of the Warren Court's performance to secure constitutional justice for the accused, its equally significant legacy may be - as Professor Jerold Israel has suggested - "the long-range consequences that flowed from its direction of public attention" to the general problem, leading to "various reforms in the criminal justice process that have benefitted the accused." Thus, the populace "came to recognize that police training involves more than teaching people to shoot straight, that we must devote substantial resources to police training, and that we must recruit our police from all groups in the community." The bar came to perceive "criminal law as an area of intellectual and social challenge, and this, in turn, induced more able lawyers to enter that field, particularly in the offices of public defenders and prosecuting attorneys." And the lawmakers, led by "[v]arious distinguished professional groups, such as the American Bar Association, American Law Institute, and the National Conference of Commissioners on Uniform State Laws," came to reexamine the role of legislation in the criminal procedure field. The proposed reforms "did not always indicate whole-hearted support of particular Warren Court decisions, but they certainly reflected a general concern for the rights of the accused and urged expansion of those rights in many areas, such as pretrial discovery."367

363. See, e.g., O'Callahan, 395 U.S. at 265-66; Reid v. Covert, 354 U.S. at 37-39 (plurality opinion); Everett, supra note 362, at 866 n.55; Sherman, The Civilianization of Military Law, 22 ME. L. REV. 3 (1970); Note, Military Trial of Civilian Offenses: Drumhead Justice in the Land of the Free, 43 S. CAL. L. REv. 356, 363-64 (1970).

364. See W. Generous, supra note 357, at 179.

365. See id. at 184-85.

366. See id. at 179.

367. Israel, supra note 216, at 1424 n.438. 


\section{Free Expression and Association}

\section{Censorship}

The first half of this century was a period "marked by unbridled censorship"368 of motion pictures in the United States. As Chief Justice Warren remarked in his 1961 dissent in Times Film Corp. v. Chicago, ${ }^{369}$ "[a] revelation of the extent to which censorship has recently been used in this country is indeed astonishing." 370

Objections grounded in political, racial, moral and religious prejudices usually motivated the deletions required in films or the outright bans on their being shown. ${ }^{371}$ Police officers assigned to the Chi-

368. R. RaNdali, Censorship of the Movies 24 (1968).

369. 365 U.S. 43 (1961).

370. 365 U.S. at 69 (Warren, C.J., dissenting).

371. Specific illustrations provide a fuller flavor. With respect to political themes, The Spirit of 76, a movie depicting atrocities by British soldiers during the Revolutionary War, was banned in Chicago. E. DE Grazia \& R. NEWMAN, BANNED FILMS 20 (1982). As pointed out by Chief Justice Warren, "Before World War II, the Chicago censor denied licenses to a number of films portraying and criticizing life in Nazi Germany including the March of Time's Inside Nazi Germany." 365 U.S. at 69 . "Maryland censors restricted a Polish documentary film on the basis that it failed to present a true picture of modern Poland," and excised the sentence "We, the workers of the world, will take care of that" from Idiot's Delight. 365 U.S. at 70-71. In New York, the board eliminated from Potemkin a picture of Lenin's tomb because it bore the inscription "Religion is the opiate of the people." 365 U.S. at 71. "Professor Mamlock was produced in Russia and portrayed the persecution of the Jews by Nazis. The Ohio censors condemned it as 'harmful' and calculated to 'stir up hatred and ill will and gain nothing.' It was released only after substantial deletions were made. The police refused to permit its showing in Providence, Rhode Island, on the ground that it was communistic propaganda. Millions of Us, a strong union propaganda film, encountered trouble in a number of jurisdictions." 365 U.S. at 71. In Pennsylvania, "several rather mild anti-Fascist statements" were cut from Spanish Earth, a pro-Loyalist film based on the Spanish Civil War. R. RaNDAII, supra note 368, at 24. "Charlie Chaplin's satire on Hitler, The Great Dictator, was banned in Chicago, apparently out of deference to its large German population." 365 U.S. at 72. The Detroit and Pennsylvania censors rejected The Youth of Maxim - described by the New York Herald Tribune as "a stirring, vivid and beautifully integrated document of the Russian Social-Democratic movement" - on the ground that it was "pure Soviet propaganda." E. DE GRAZIA \& R. NEWMAN, supra, at 212-13. Other Chaplin films were barred in Memphis because of his Communist associations. Memphis Commercial Appeal, Oct. 16, 1972, at 15, col. 6. [hereinafter cited as Memphis Commercial Appeal]. Both "Ohio and Kansas banned newsreels considered pro labor. Kansas ordered a speech by Senator Wheeler opposing the bill for enlarging the Supreme Court to be cut from the March of Time as 'partisan and biased.' " 365 U.S. at 72. Finally, Chicago banned newsreels showing city police shooting at labor pickets, 365 U.S at 69, and during a 12-month period in 1937-1938, Massachusetts "required 13 deletions from newsreels and the March of Time series." E. DE GRAZIA \& R. NEWMAN, supra, at 202.

As for the subject of civil rights, "[b]eginning in 1915 with Birth of a Nation, which portrayed supposed excesses of Reconstruction, courts sustained the right of communities to censor films touching upon race questions." R. RANDALL, supra note 368 , at 24 . Thus,

[t]he Memphis censors banned The Southerner which dealt with poverty among tenant farmers because it "reflects on the south." Brewster's Millions, an innocuous comedy of [forty] years ago, was . . . forbidden in Memphis because the radio and film character Rochester, a Negro, was deemed "too familiar." . . . No Way Out, the story of a Negro doctor's struggle against race prejudice, was banned by the Chicago censor on the ground that "there's a possibility it could cause trouble." The principal objection to the film was that the conclusion showed no reconciliation between blacks and whites. The ban was lifted after a storm of protest and later deletion of a scene showing Negroes and whites arming for 
cago censor unit described the dominant attitude: "Coarse language or anything that would be derogatory to the government - propaganda" is ruled out of foreign films. "Nothing pink or red is allowed."372 "Children should be allowed to see any movie that plays in Chicago . . . . If a picture is objectionable for a child, it is objectionable period."373 During World War I, "[m]ovies praising pacifism or denouncing war were widely banned by local censors."374 But idiosyncratic whims also operated, as exemplified by the Memphis board's prohibition on all train robbery films because its chairman had once been so victimized when he had worked as a railroad mail clerk. ${ }^{375}$

a gang fight. Memphis banned Curley because it contained scenes of white and Negro children in school together. Atlanta barred Lost Boundaries, the story of a Negro physician and his family who "passed" for white, on the ground that the exhibition of said picture "will adversely affect the peace, morals and good order" in the city.

365 U.S at 70 (citations omitted). A movie of the Willard-Johnson heavyweight championship fight in Cuba was refused entry into the United States. E. DE GRAZIA \& R. NEwMAN, supra, at 185.

Not surprisingly, moral and religious fervor produced many prohibitions. Because she had borne an illegitimate child, Ingrid Bergman's films were excluded in Memphis. Memphis Commercial Appeal, supra. Chicago's censors "ordered the deletion of a scene depicting the birth of a buffalo in Walt Disney's Vanishing Prairie" and refused a license for Anatomy of a Murder because they "found the use of the words 'rape' and 'contraceptive' to be objectionable. 365 U.S at 69. "Witchcraft, a study of superstition through the ages, was suppressed for years because it depicted the devil as a genial rake with amorous leanings, and because it was feared that certain historical scenes, portraying the excesses of religious fanatics, might offend religion." "New York censors banned Damaged Lives, a film dealing with venereal disease, although it treated a difficult theme with dignity and had the sponsorship of the American Social Hygiene Society." 365 U.S at 71. "An early version of Carmen was condemned on several different grounds. The Ohio censor objected because cigarette-girls smoked cigarettes in public. The Pennsylvania censor disapproved the duration of a kiss." More generally, "[t]he New York censors forbade the discussion in films of pregnancy, venereal disease, eugenics, birth control, abortion, illegitimacy, prostitution, miscegenation and divorce. A member of the Chicago censor board explained that she rejected a film because it was immoral, corrupt, indecent, against my . . . religious principles." " 365 U.S at 72 (citation omitted).

Finally, periodic objections were made to films depicting illegal conduct. For example, "Scarface, thought by some as the best of the gangster films, was held up for months; then it was so badly mutilated that retakes costing a hundred thousand dollars were required to preserve continuity." 365 U.S at 71. In Memphis, Dead End, "which is now something of a classic, starred Humphrey Bogart, and was banned because it would encourage crime . . . and there is no need of showing a picture that might influence boys how to be gangsters." " Note, Film is a Four Letter Word, 5 MEMPHIS ST. U. L. REV. 41 , 46 n.47 (1974).

The Chicago censor bureau excised a scene in Street With No Name in which a girl was slapped because this was thought to be a "too violent" episode. It Happened in Europe was severely cut by the Ohio censors who deleted scenes of war orphans resorting to violence. The moral theme of the picture was that such children could even then be saved by love, affection and satisfaction of their basic needs for food.

365 U.S. at 69-70 (citation omitted). And the Maryland licensors ordered that a scene from The Man with the Golden Arm, depicting a narcotics addict injecting himself with heroin, be excised. See United Artists Corp. v. Maryland State Bd. of Censors, 210 Md. 586, 124 A.2d 292 (1956) (holding that scene was likely to deter narcotics use and should not have been eliminated).

372. Chicago Daily News, Apr. 7, 1959, at 3, cols. 7-8.

373. Chicago Tribune, May 24, 1959, at 8, col. 3.

374. E. DE GRAZIA \& R. NEWMAN, supra note 371, at 19.

375. Memphis Commercial Appeal, supra note 371. 
Complete statistics as to the total number of films either banned or edited are not available. But scattered data suggest a very large amount of censorship. Thus, in 1921, New York's censors "banned or demanded deletions in $\mathbf{2 3 5}$ movies for being 'indecent,' 'inhuman,' 'immoral,' or 'tending to incite to crime.' Three years later, the number jumped to $3684 . " 376$ "When it lacked sufficient personnel to do the job, the commission enlisted state troopers. It was not an easy task."377 In 1938, "the New York board censored, in one way or another, over five percent of the moving pictures it reviewed." $378 \mathrm{Be}$ tween 1943 and 1947, the Empire State censored over 100 movies per year. ${ }^{379}$ In the early 1960's - even after, as shall become evident later, censorship was in sharp decline - the state boards in Maryland, New York and Virginia each imposed their views on at least an average of thirty films per year. ${ }^{380}$ Finally, although (as shall also be shown later) judicial review would often correct the over-zealous censor, indications were that many exhibitors were inclined simply to capitulate ${ }^{381}$ rather than "assume the burden of instituting judicial proceedings and of persuading the courts that the film is protected expression." 382

Although the Court did not impose exacting procedural strictures on movie censorship systems until $1965,{ }^{383}$ it turned the corner thirteen years earlier, in Joseph Burstyn, Inc. v. Wilson, ${ }^{384}$ when it held that motion pictures were a form of expression protected by the first and fourteenth amendments. The ruling's effect was twofold. First, " $[t]$ he new freedom it provided helped to stimulate a maturity in the medium that eventually saw greater sophistication of subject and treatment ...."385 Second, after Burstyn, a "considerable antilicensing swell" 386 mounted. In the next few years, the Justices, in a series of per curiam decisions, rejected "all but one of the principal statutory censorship criteria that censors had applied for decades to

376. E. DE GRAZIA \& R. NEWMAN, supra note 371, at 28.

377. Id.

378. 365 U.S. at 71-72.

379. R. RANDALL, supra note 368 , at 108 (table 5).

380. Id. at 40 (table 1).

381. See M. ERNST \& A. LindLy, The Censor MARChes ON 80 (1940); Lockhart \& McClure, Literature, the Law of Obscenity, and the Constitution, 38 MINN. L. REv. 295, 314-16 (1954) [hereinafter cited as Literature].

382. Freedman v. Maryland, 380 U.S. 51, 59-60 (1965).

383. See Freedman v. Maryland, 380 U.S. 51 (1965).

384. 343 U.S. 495 (1952).

385. R. RANDALL, supra note 368 , at 32 .

386. Id. at 41. 
prevent the showing of films."387 The supreme courts of a number of states struck down movie censorship schemes, either as forbidden by the federal Constitution ${ }^{388}$ or the free speech provisions of their state constitutions. ${ }^{389}$ Even the Court's 1961 refusal in Times Film to condemn all prior submission systems for films did not diminish the forces let loose by Burstyn. Significantly influenced by Chief Justice Warren's powerful dissent in Times Film, no reported appellate decisions (mostly by state courts) during the four years following Times Film sustained the censors on the merits; one state court went "so far as to quote only from ... [the Warren dissent] while not mentioning the Times Film majority opinion."390 Between 1952 and 1960, not once did the Illinois courts uphold the Chicago unit when the exhibitor elected to appeal.391 Only twice between 1952 and 1965 did the New York judiciary uphold that state's censorship board. ${ }^{392}$ Moreover, the number of censorship boards active throughout the country also "decreased appreciably." 393

In 1965, Freedman v. Maryland ${ }^{394}$ critically (although not fatally) wounded motion picture censorship by ruling that although the first amendment does not flatly forbid laws requiring advance submission of films to a censor, there must be a series of "procedural safeguards designed to obviate the dangers of a censorship system":395 if the censor believes that the film is constitutionally unprotected, the censor must take the initiative by promptly seeking an injunction; the censor bears the burden of proof; and there must be an expeditious final judicial decision. ${ }^{396}$

387. E. DE GRAZIA \& R. NEWMAN, supra note 371, at 83-84.

388. See R.K.O. Radio Pictures v. Department of Educ., 162 Ohio St. 263, 122 N.E.2d 769

(1954); Brattle Films v. Commissioner of Pub. Safety, 333 Mass. 58, 127 N.E.2d 891 (1955).

389. In four of these cases, licensing itself was invalidated under free speech provisions of state constitutions. In two others, procedural deficiencies were found in licensing laws, and in two more, licensing standards were held misapplied to particular films. Finally, in three cases in which the censors prevailed, two turned on the fact that the film proprietor had proceeded improperly, and the third on the appellate court's refusal to consider the obscenity issue or to view the film, thereby letting stand an adverse decision in the trial court.

R. RANDALL, supra note 368 , at $39-40$ (footnotes omitted).

390. S. WASBY, supra note 18 , at 139.

391. Times Film Corp. v. City of Chicago, 365 U.S. 43, $72-73$ (1961).

392. I. Carmen, Movies, Censorship and the Law 148 (1966).

393. R. RANDALL, supra note 368, at 17; see I. CARMEN, supra note 392, at 184 (perhaps as many as 90 censorship boards in the early 1950 's); R. RANDALL, supra note 368 , at 40 (5 states and 48 municipalities in 1959; down to 4 states and 27 municipalities with active boards in 1963); Freedman v. Maryland, 380 U.S. 51, 59 n.5 (1965) (down to 4 states and 15 municipalities in 1965).

394. 380 U.S. 51 (1965).

395. 380 U.S. at 58.

396. 380 U.S. at 58-59. 
As a result of Freedman's carefully circumscribed requirements, "[l] egal censorship of movies was virtually dead." 397 After state courts in Kansas, ${ }^{398}$ Virginia, ${ }^{399}$ and New York ${ }^{400}$ found their respective schemes wanting under Freedman, state legislatures simply abandoned the enterprise. ${ }^{401}$ Maryland, the only state that actively persisted in the field, redrafted its statute to conform to Freedman, ${ }^{402}$ but its highest court continued to elevate the censor board's burden ${ }^{403}$ so that "[v]ery few films have been banned in Maryland under its new law."404

Similarly, state and federal courts invalidated licensing schemes in several municipalities. ${ }^{405}$ Dallas subsequently cured its procedural infirmities, ${ }^{406}$ first imposing "what were probably the most elaborate procedural obligations ever required of a prior censorship agency," 407 and then totally eliminating administrative discretion to bar exhibition of any film whose distributor agrees that it be classified as "Not Suitable for Young Persons." 408 A Providence ordinance (enacted pursuant to an amended Rhode Island enabling statute) strictly "safeguard[s] the right of a motion picture exhibitor against unwarranted prior restraint." 409

397. R. Liston, The Right to KNOW: Censorship IN AMERICA 51 (1973).

398. State v. Columbia Pictures Corp., 197 Kan. 448, 417 P.2d 255 (1966).

399. Victoria Films v. Division of Motion Picture Censorship (Richmond Cir. Ct. 1965) (unreported), noted in R. RANDALL, supra note 368, at $241 \mathrm{n} .43$.

400. Cambist Films, Inc. v. Board of Regents, 46 Misc. 2d 513, 260 N.Y.S.2d 804 (Sup. Ct. 1965).

401. S. WASBY, supra note 18, at 139.

402. See Trans-Lux Distrib. Corp. v. Maryland State Bd. of Censors, 240 Md. 98,213 A.2d 235 (1965).

403. See Hewitt v. Maryland State Bd. of Censors, 241 Md. 283, 216 A.2d 557 (1966), 243 Md. 574, 221 A.2d 894 (1966); Dunn v. Maryland State Bd. of Censors, 240 Md. 249, 213 A.2d 751 (1965). See generally R. RANDALL, supra note 368, at 46-47.

404. M. MAYER, THE FILM INDUSTRIES 139 (rev. ed. 1978).

405. See, e.g., Teitel Film Corp. v. Cusack, 390 U.S. 139 (1968) (Chicago); National Assn. of Theatre Owners v. Motion Pictures Commn., 328 F. Supp. 6 (E.D. Wis. 1971) (Milwaukee); Interstate Circuit, Inc. v. Dallas, 247 F. Supp. 906 (N.D. Tex. 1965) (Dallas); Embassy Pictures Corp. v. Hudson, 242 F. Supp. 975 (W.D. Tenn. 1965) (Memphis); Fine Arts Guild, Inc. v. Seattle, 74 Wash. 2d 503, 445 P.2d 602 (1968) (Seattle); see also Grove Press, Inc. v. Philadelphia, 418 F.2d 82 (3d Cir. 1969); Commonwealth v. Guild Theatre, Inc., 432 Pa. 378, 248 A.2d 45 (1968) (successful challenges to a Pennsylvania procedure authorizing injunctions against films already being shown). Chicago revised its licensing scheme to meet the Freedman standards. Universal Film Exchanges, Inc. v. Chicago, 288 F. Supp. 286 (N.D. Ill. 1968). Memphis has since established a system of dubious validity. See Note, supra note 371, at 51-58.

406. Interstate Circuit, Inc. v. Dallas, 390 U.S. 676, 690 n.22 (1968).

407. R. RANDALl, supra note 368, at 47. See generally Note, A Model Movie Censorship Ordinance, 5 HARV. J. ON LEGIS. 395 (1968).

408. Dailas, Tex. CITY CODE § 46-15(b) (1979).

409. Shipyard Drive-In-Theatre, Inc. v. Scuncio, 107 R.I. 554, 567, 268 A.2d 820, 828 (1970), appeal dismissed, 401 U.S. 1005 (1971). 
In all, movie censorship has "existed in principle after Freedman but in highly circumscribed form and had life in only a few locations." 410 The Justices' rulings, by emasculating the legal mechanisms that prevented satisfaction of market pressures, ${ }^{411}$ have immeasurably expanded the viewing fare of the American public.

\section{Defamation}

Because there are no comprehensive empirical data available, it is impossible to demonstrate the exact extent to which fear of damage judgments for libel, before 1964, deterred the news media from publishing matters of public interest. Nevertheless, the number and size of such awards suggests that there was a substantial chilling effect. For example, at the time of the Court's landmark decision in New York Times Co. v. Sullivan, ${ }^{412}$ which overturned a jury verdict of $\$ 500,000$ against the newspaper and four other defendants for publishing a defamatory advertisement by civil rights protesters, "libel suits for nearly $\$ 300$ million were pending against news organizations active in the South."413 Overall, there can be little doubt that the potential of such crushing liability significantly influenced newspapers and broadcasters to engage in self-censorship, thus limiting the dissemination of a wide range of information, at least some of which was of genuine concern to the public. ${ }^{414}$

New York Times, and its progeny that have amplified protection of journalistic discretion, ${ }^{415}$ has not fully eliminated the chilling effect of

410. S. WASBY, supra note 18 , at 139.

411. For a description of the decline of the motion picture industry's self-censorship system for similar reasons, see R. LISTON, THE RIGHT to KNOW: CENSORSHIP IN AMERICA 44-46 (1973); see also E. DE GRAZIA \& R. NEWMAN, supra note 371, at 85-86 ("The Supreme Court's rulings indirectly undermined the intellectual and legal authority of the industry's Production Code.").

412. 376 U.S 254 (1964).

413. Kupferberg, Libel Fever, Colum. Journalism Rev., Sept./Oct. 1981, at 36, 37.

414. This phenomenon has not been unique to the United States. For example, in England where, in addition to vague and potentially harsh contempt laws, see generally $\mathrm{C}$. WINTOUR, PRESSURES ON THE PRESS 129-40 (1972), "staggering jury verdicts" have been rendered pursuant to the English libel rules, it has been reported that in the early 1960's, newspapers withheld reporting damaging details of the Profumo "sex and security" scandal for half a year. Dickinson, Libel Suits and Press Freedom, 2 EDITORIAL ReseARCH RePS. 883, 891 (1963).The editor of the New Statesman explained that " $[t]$ he press has a duty - but we cannot always afford to perform it." Id. (quoting Roth, Britain's Libel Laws Keep Profumo Case Under Cover, EDrToR \& PUBLISHER, June 15, 1963, at 11). Indeed, British publishers even delayed printing Lord Denning's official report on the affair until Parliament afforded the media a "qualified privilege" on publication. Dickinson, supra, at 891.

415. See, e.g., Cox Broadcasting Corp. v. Cohn, 420 U.S. 469 (1975); Monitor Patriot Co. v. Roy, 401 U.S. 265 (1971), remanded in part, 112 N.H. 80, 290 A.2d 207 (1972); Greenbelt Coop. Publishing Assn. v. Bresler, 398 U.S. 6 (1970); Curtis Publishing Co. v. Butts, 388 U.S. 130 (1967); Time, Inc. v. Hill, 385 U.S. 374 (1967); Rosenblatt v. Baer, 383 U.S. 75 (1966). 
possible defamation actions. ${ }^{416}$ But these decisions have significantly relieved the problem, a conclusion evidenced by both informed opinion and hard facts. An illustration of the former is the Los Angeles Times lawyer's comment on investigative reporting concerning public officials and public figures: "If the article is properly structured any rational lawyer will recognize that a libel action . . . would be futile and would be dismissed under one of the various privileges."417 Other news media attorneys feel "that material is now being published that would not have been before Times."418 Indeed, the journal of the American Newspaper Publishers Association recently reported that

416. For example, "[m]ore libel decisions were reported in the United States in 1973 than in 1963, the last full year before the upheaval began." Anderson, Libel and Press Self-Censorship, 53 TEx. L. Rev. 422, 430 (1975) [hereinafter cited as Anderson, Libel and Press]. And Supreme Court decisions subsequent to New York Times have upheld substantial judgments for plaintiffs. See Curtis Publishing Co. v. Butts, 388 U.S. 130, 138 (1967) $(\$ 460,000)$; Rosenbloom v. Metromedia, Inc., 403 U.S. $29,40(1971)(\$ 275,000)$. More recently, there have been jury awards of $\$ 39.6$ million (reduced to \$4 million) against Hustler magazine, \$26.5 million (reduced to \$14 million) against Penthouse magazine, $\$ 9.2$ million against the Alton (Ill.) Telegraph, $\$ 4.6$ million against the San Francisco Examiner, \$1.6 million (reduced to \$800,000) against the National Enquirer, and \$1 million against the Daily Oklahoman. Franklin, Suing Media for Libel: $A$ Litigation Study, 1981 AM. B. Found. RESEARCH J. 797, 797 n.1; Kupferberg, supra note 413, at 36. Furthermore, the anecdotal evidence also demonstrates that publishers are still deterred from publishing some materials for fear of libel actions. In Cleveland, investigative reporters "considerably diluted" the impact of a 1975 television program on deceptive selling practices by hearing aid dealers, even after a federal court had denied an injunction sought by one of the interviewees. The "news department made a journalistic decision to proceed with the story, and a business decision to make that story weaker, but legally defensible." Neff, Cleveland: Watering Down the News, Colum. JourNALiSM Rev., May 1975, at 39. In 1974, after the subject of an article on theft by a public official threatened a libel suit, a San Jose newspaper published a clarification and ordered its staff off the story, despite its lawyer's judgment that a retraction was unnecessary and that the paper was on firm legal ground. The subject's "implied threat succeeded [not only] in rectifying a questionable interpretation of his letter by reporters - but also in ending the paper's investigation into his affairs." Anderson, San Jose: Threatening a Libel Suit, 14 Colum. Journalism Rev., May 1975, at 40 [hereinafter cited as Anderson, San Jose]. Also, in 1974, a journalism review

deleted certain passages from an article for fear that publication of them would result in legal action. The review had consulted its lawyers, who advised that it would probably win a libel suit, "but that the cost of defending it might easily bankrupt the magazine. After a good deal of agonizing, ... . we decided that the risk was not worth it." The article in question charged that the New York Times had refused to publish a manuscript by one of its investigative reporters, even though that newspaper's lawyers also had reviewed the charges and concluded that a libel suit would probably be filed, but could be defended successfully. The passages censored . . . were excerpts from that manuscript; thus neither publication printed the material, even though the lawyers for both independently had concluded that it probably was not libelous.

Anderson, Libel and Press, supra, at 431 (footnotes omitted). Additional evidence may be found in the recent admonition to journalists by the general counsel of the Los Angeles Times - advice duplicated at numerous similar seminars throughout the country - "to keep your sources of possible libel suits to a minimum." Seminar, Urban Policy Research Institute 12 (Jan. 10, 1976) [hereinafter cited as Seminar].

417. Seminar, supra note 416, at 14-15.

418. Anderson, Libel and Press, supra note 416, at 430 (citing Le Maistre, Who Needs Egg on His Face?, 4 JURIS Dr. 33-34 (May 1974)). 
"no newspaper admits to even considering"419 " 'backing off' on news coverage to avoid legal entanglements." 420 Although this last stated view is unquestionably exaggerated, the fact is that "suits against media defendants are not likely to be rewarding."421

Even those cases modifying the thrust of New York Times, such as Gertz v. Robert Welch, Inc., ${ }^{422}$ Time, Inc. v. Firestone, ${ }^{423}$ Hutchinson v. Proxmire ${ }^{424}$ and Wolston v. Reader's Digest Assn. ${ }^{425}$ - which media advocates have criticized as creating uncertainties and consequent inhibitions for publishers and broadcasters, ${ }^{426}$ and as particularly threatening "the smaller, newer, and less conventional media voices"427 have not been without value in furthering freedom of the press. A careful study of Hutchinson's and Wolston's impact during their first year and a half of influence disclosed no significant effects for media

419. Rambo, Old Nemesis Haunts Press: Suits Multiply, Rulings Sting (Special Report on Libel), Presstime, Nov. 1980, at 4.

420. Id. However, "several media attorneys express the fear that it will happen if libel costs continue to increase." Id.

421. Franklin, supra note 416 , at 829 . An extensive study of defamation litigation against the media between 1976 and 1980 disclosed that "plaintiffs win a low percentage of appeals (5 percent) compared to the success rate of 66 percent for defendants." Id. at $829,803 \& \mathrm{n} .17$; see also Franklin, Winners and Losers and Why: A Study of Defamation Litigation, 1980 AM. B. FOUND. RESEARCH J. 455, 489 (noting similar disparity in 1976-1979 study) [hereinafter cited as Winners and Losers]. Moreover, whereas plaintiffs who lose at trial often abandon their cases, it is "most unusual for media defendants to make any payment whatever without an appellate decision." Winners and Losers, supra, at 461, 462-63. In the cases that were appealed, "trial court rulings [often on motions to dismiss or on summary judgment had] favored defendants 75 percent of the time." Franklin, supra note 416, at 802 . Although there has been no systematic study of settlements by media defendants, fragmentary information suggests that they are fairly few in number and quite small in amount. Franklin, supra note 416, at 800 n.12. But see Rambo, supra note 420 , at 5 (\$600,000 settlement by San Francisco Examiner). Moreover, it appears that few really large awards have ever been paid. Rambo, supra note 419 , at 5 . In addition, it is now estimated that "at least half of the 1,765 daily newspapers and 8,000 weeklies in the United States carry libel insurance; they are, in other words, prepared for suits and consider the cost of insurance as part of the price of doing business." Pickerell, Public Rights vs. Private Rights, Long Beach Press-Telegram, Nov. 19, 1981, at B9, col. 6; Kupferberg, supra note 413, at 39. As for legal fees for pre-publication counseling and libel defense, see Franklin, supra note 416 , at 800 n.13. Finally, to the extent that publishers and broadcasters are ultimately held liable, in the judgment of the American Newspaper Publishers Associations' general counsel, it is largely because journalists have failed to "clean up their act . . . . The editors really aren't on the job . . . [and reporters] are reporting their ego trips." Hanson, Editor and Publisher, Oct. 24,1981 , p. 46.

422. 418 U.S 323 (1974), cert. denied on appeal after remand, 680 F.2d 527 (7th Cir. 1982).

423. 424 U.S. 448 (1976).

424. 443 U.S. 111 (1979).

425. 443 U.S. 157 (1979).

426. See generally Anderson, Libel and Press, supra note 416 (assessing the effectiveness of the Times-Gertz privilege in preventing self-censorship); Stonecipher \& Trager, The Impact of Gertz on the Law of Libel, 53 JoURNALISM Q. 609 (1976) (discussing lower court interpretations of the Gertz fault standard and the Gertz public figure criteria).

427. Anderson, The Selective Impact of Libel Law, Colum. JouRNalisM REv., May 1975, at 38,38 . 
defendants. ${ }^{428}$ Furthermore, it has been predicted that Gertz's limitations on the spectre of catastrophic damages "should make libel more readily insurable by making awards more predictable;" "insurance companies should be able to evaluate risks more accurately, and therefore be more willing to underwrite risks previously avoided." 429 This consequence is "the most promising approach" 430 for fulfilling the first amendment's "profound national commitment to the principle that debate on public issues should be uninhibited, robust, and wideopen."431

\section{Loyalty-Security}

There appears to be neither comprehensive data, nor adequate reliable sources for assembling it, on the number of Americans adversely affected by the sweeping post-World War II assaults on communicative and associational rights posed by government loyalty-security programs. These regulations applied to a great many vocations, benefits and activities ${ }^{432}$ and were imposed by a majority of states ${ }^{433}$ as well as the federal government.434 In all, it was estimated that "more than one-sixth of the total civilian labor force was subject to some type of loyalty qualification," 435 the most common forms being traditional loyalty oaths, ${ }^{436}$ substantive restrictions for the job, ${ }^{437}$ and required

428. Franklin, supra note 416, at 821-26.

429. Anderson, supra note 427, at 42; see Libel Insurance Available from Six Different Carriers (Special Report on Libel), Presstime, Nov. 1980, at 10.

430. Anderson, supra note 427, at 42.

431. New York Times Co., 376 U.S. at 270.

432. See, e.g., Communist Party v. Whitcomb, 414 U.S. 441 (1974) (ballot access); Baggett v. Bullitt, 377 U.S. 360 (1964) (public employment); Speiser v. Randall, 357 U.S. 513 (1958) (tax exemptions); Schware v. Board of Bar Examiners, 353 U.S. 232 (1957) (practice of law).

433. As of 1958, 24 jurisdictions subjected all public employees to the regime of these schemes and seven more states covered teachers. R. BROWN, JR., LOYALTY AND SECURITY 92 $\&$ n.2 (1958). Various states also applied them to welfare benefits, see, e.g., State v. Hamilton, 110 N.E.2d 37 (Ohio Ct. App. 1951) (unemployment benefits), public housing tenancy, see, e.g., Lawson v. Housing Auth., 70 N.W.2d 605 (Wis.), cert. denied, 350 U.S. 882 (1953), and even to social workers, veterinarians, boxers and wrestlers. See generally R. BROWN, supra, at 21-119, 164-83; W. GellHoRn, INDIVIDUAL FREedom AND GoverNMENTAL RESTRAinTS 129-30 (1956) (discussing seemingly irrelevant loyalty oaths and investigations in licensing matters); Morris, Academic Freedom and Loyalty Oaths, 28 LAW \& CONTEMP. PrOBS. 487, $496-97$ (1963) (detailing epidemic of loyalty-security programs).

434. See, e.g., Schneider v. Smith, 390 U.S. 17 (1968) (licensed seamen); United States v. Brown, 381 U.S. 437 (1965) (labor leaders); Woodward v. Rogers, 344 F. Supp. 974 (D.D.C. 1972), affd., 486 F.2d 1317 (D.C. Cir. 1973) (passports).

435. Developments in the Law - The National Security Interest and Civil Liberties, 85 HARV. L. REV. 1130, 1160 \& n.144 (1972) (citing T. EMERSON, THE SYSTEM OF FrEEDOM OF EXPREsSION 206 (1970)).

436. See, e.g., Elfbrandt v. Russell, 384 U.S. 11 (1966).

437. See, e.g., United States v. Robel, 389 U.S. 258 (1967). 
disclosures as a condition of employment. 438

Although the harmful repercussions of these programs are difficult to measure specifically, apart from those persons who actually experienced the physical and mental agonies associated with the lasting stain of false charges of disloyalty, ${ }^{439}$ there would appear to be two major groups of people who suffered their burdens. First, there were those who were deterred from seeking various jobs or benefits because of prior conduct that had been lawful when engaged in. For example, it has been estimated that as many as one million former Communists were present in the population. ${ }^{440}$ Second, there were those whose behavior, both at work and avocationally, was restrained because of the threat of being fired or subjected to more severe penalties. Thus, a 1952 survey of government employees of professional rank recounted widespread fear of open political discussion even with close friends and fellow employees, alteration of reading habits and ownership of books, and reluctance to join organizations. ${ }^{441}$

On the other side of the scale, although there appears to be no hard information on the number of "real subversives" who were actually deterred from seeking "sensitive" positions in either the public or private sectors, existing data tend to show that a distressingly small government interest was served despite the programs' encompassing reach. ${ }^{442}$ This may be seen especially in the litigated cases, many of which involved members of pacifist religious groups. ${ }^{443}$

In a long series of rulings (grounded in such constitutional doc-

438. See, e.g., Konigsberg v. State Bar, 353 U.S. 252 (1957).

439. See, e.g., Jahoda \& Cook, Security Measures and Freedom of Thought: An Exploratory Study of the Impact of Loyalty and Security Programs, 61 YALE L.J. 295, 316-17 (1952).

440. See Sager, The Impact of Supreme Court Loyalty Oath Decisions, 22 AM. U. L. REv. 39, 64 (1972).

441. See Jahoda \& Cook, supra note 439, at 308-15. An authoritative study in 1958 - confirmed more recently in 1972 - disclosed that $76 \%$ of teachers believed that loyalty systems would negatively affect their ability to teach properly. Sager, supra note 440, at 67-68.

442. For example, in Keyishian v. Board of Regents, 385 U.S. 589 (1967), although a meeting of between 300 and 400 faculty members at the State University of New York at Buffalo originally opposed the contemplated loyalty system, by the time the action was commenced, only four (against whom no evidence of disloyalty was adduced) still refused to sign the oath. Brief for Appellants at 9, Keyishian. Similarly, a 1953 study of the newly enacted Pennsylvania program found that the "only tangible results" were the resignation in protest of one official after he had taken the oath and the discharge of eight admittedly unimpeachable employees. Byse, $A$ Report on the Pennsylvania Loyalty Act, 101 U. PA. L. REv. 480, 482 (1953). In the west, 26 members of the University of California faculty were dismissed for refusing to sign the Regents' oath and 37 others resigned in protest; there was no evidence that any was a communist. R. BRown, supra note 433 , at 95 .

443. See, e.g., Whitehill v. Elkins, 389 U.S. 54 (1967); Elfbrandt v. Russell, 384 U.S. 11 (1966); In re Summers, 325 U.S. 561 (1945); see also Byse, supra note 442, at 482-83 (describing Quaker objections to loyalty oaths). 
trines as vagueness, ${ }^{444}$ overbreadth, ${ }^{445}$ and procedural fairness ${ }^{446}$ ), the judiciary effectively eliminated the chilling consequences of the nation's loyalty-security restrictions - although the Court's record in this area during the 1950's and 1960's was by no means uniform and has been said to have been significantly influenced by the national political climate. ${ }^{447}$ The Justices' impact is perhaps most sharply illustrated by the fact that between 1965 and 1972 virtually all of the thirty-three state and federal provisions for teachers that were on the books in 1964 were formally laid to rest - six by the Supreme Court and, following its lead, nineteen by lower federal courts, two by state courts, and four by state attorneys general. 448

\section{Obscenity}

In its 1957 ruling in Roth v. United States, ${ }^{449}$ the Supreme Court held for the first time that "portrayal of sex . . . in art, literature and scientific works" 450 - unless it constitutes "obscenity" - falls within the protection of the first amendment. While a majority of American jurisdictions had already adopted the Roth view ${ }^{451}$ (although not as a constitutional requirement), many had not. Contrary to the Supreme Court's rule that, in order to be "obscene," "the dominant theme of the material taken as a whole" must appeal "to prurient interest," "452 statutes in at least fourteen states - and occasional judicial decisions - had found writings to be obscene on the basis of merely "isolated passages." 453 Furthermore, although Roth stipulated that, to be "obscene," material must appeal to the prurient interest of "the average

444. E.g., Baggett v. Bullitt, 377 U.S. 360 (1964); Cramp v. Board of Pub. Instruction, 368 U.S. 278 (1961).

445. E.g., United States v. Robel, 389 U.S. 258 (1967); Bond v. Floyd, 385 U.S. 116 (1966).

446. E.g., Connell v. Higginbotham, 403 U.S. 207 (1971); Speiser v. Randall, 357 U.S. 513 (1958); Slochower v. Board of Educ., 350 U.S. 551 (1956); Board of Educ. v. Mass, 47 Cal. 2d 494, 304 P.2d 1015 (1956); Chicago Hous. Auth. v. Blackman, 4 Ill. 2d 319, 122 N.E.2d 522 (1954); Lawson v. Housing Auth., 70 N.W.2d 605 (Wis.), cert. denied, 350 U.S. 882 (1955); Nathanson v. Adams, 207 Misc. 572, 138 N.Y.S.2d 598 (1955), appeal dismissed, 148 N.Y.S.2d 742 (App. Div. 1956).

447. J. CASPER, supra note 118, at 48-52. See generally J. CHOPER, supra note 1, at 123-25.

448. Sager, supra note 440 , at 74.

449. 354 U.S. 476 (1957).

450. 354 U.S. at 487 (footnote omitted).

451. See Lockhart, Escape from the Chill of Uncertainty: Explicit Sex and the First Amendment, 9 GA. L. REv. 533, 539-40 (1975); Lockhart \& McClure, Censorship of Obscenity: The Developing Constitutional Standards, 45 MiNN. L. REv. 5, 70, 88-89 (1960) [hereinafter cited as Censorship of Obscenity]; Literature, supra note 381, at 345.

452. 354 U.S. at 489 (emphasis added).

453. See Censorship of Obscenity, supra note 451, at 89; Literature, supra note 381, at 343-44 \& n.321. 
person,"454 statutes in at least eleven states and some courts ${ }^{455}$ had continued to follow the 1868 English rule ${ }^{456}$ (repudiated by the Justices several months before $R o t h)^{457}$ that judged material on the basis of its impact on youth or other more susceptible members of society. Finally, whereas Roth and its Warren Court progeny (especially $A$ Book Named "John Cleland's Memoirs of a Woman of Pleasure" v. Attorney General of Massachusetts) 458 defined "obscenity" as that which is "utterly without redeeming social importance,"459 a number of state courts and legislatures had proscribed various forms of expression simply because they contravened the community's current moral standards. For example, the New York courts condemned D.H. Lawrence's The First Lady Chatterly on the ground that its theme is that it "is dangerous to the physical and mental health of a young woman to remain continent and that the most important thing in [Chatterly's] life, more important than any rule of law or morals, is the gratification of her sexual desire."460 In 1953, Georgia enacted a statute prohibiting distribution of "any literature offensive to chastity or modesty, expressing or presenting to the mind or view something that purity and decency forbids to be exposed." 461 The practice of censoring communication because of the objectionable nature of the ideas advocated was specifically invalidated by the Court in 1959.462

Under the restrictive pre-Roth regime, a vast amount of literature, with indisputable if not classic "social importance," fell victim to suppression. ${ }^{463}$ Yet more devastating were the less formal, but even more

454. 354 U.S. at 489 (emphasis added).

455. See Literature, supra note 381 , at 338-40.

456. Queen v. Hicklin, 3 L.R.-Q.B. 360 (1868).

457. Butler v. Michigan, 352 U.S. 380 (1957).

458. 383 U.S. 413 (1966). See generally Lockhart, supra note 451, at 541-44.

459. 354 U.S. at 484; see 383 U.S. at 418.

460. People v. Dial Press, Inc., 182 Misc. 416, 418, 48 N.Y.S.2d 480, 483 (Mag. Ct. 1944) (quoting People v. Berg, 241 A.D. 543, 544-45, 272 N.Y.S. 586, 587-88 (1934)), affd., 269 N.Y. 514,199 N.E. 513 (1935)). Other books were rejected in New York because they tended to "lower the standards of right and wrong specifically as to the sexual relation." People v. Vanguard Press, Inc., 192 Misc. 127, 130, 84 N.Y.S.2d 427, 430 (Mag. Ct. 1947); People v. Berg, 241 A.D. $543,544-45,272$ N.Y.S. 586, 587-88 (1934), affd., 269 N.Y. 514,199 N.E. 513 (1935). In Massachusetts, Theodore Dreiser's An American Tragedy was prosecuted because "[i]n the story, Clyde had killed his lovemate Roberta when her pregnancy threatened his social plans and an advantageous marriage. 'A story like this is indecent,' declaimed the district attorney. 'It's an invitation to young people to learn birth control.'" A. HAYES, CITY LAWYER 238-39 (1942).

461. GA. CODE ANN. § 26-6301a (1953).

462. Kingsley Intl. Pictures Corp. v. Regents of Univ. of N.Y., 360 U.S. 684 (1959).

463. Apart from titles already mentioned, the following books were among those determined to be "obscene" by courts or federal postal officials: Henry Miller's Tropic of Cancer, Lewis, The Most Recent Troubles of "Tropic": A Chapter in Censorship, N.Y. Times Sunday Book Rev., Jan. 21, 1962, at 4; Boccaccio's Decameron, Apuleius' Golden Ass, Lillian Smith's Strange Fruit, Erskine Caldwell's God's Little Acre, Literature, supra note 381, at 303 n.60; Alberto Moravio's 
effective, tactics of police and district attorneys and the National Organization for Decent Literature (formed under the auspices of the Roman Catholic Hierarchy and extending to virtually every diocese in the country) who compiled "blacklists" and, through direct threats of boycott and implied threats of prosecution, succeeded in having between 300 and 750 titles of paperbacks withdrawn from sale in most American communities. ${ }^{464}$

Beyond this, the general inhibiting effects that the permissive preRoth rules had on authors, editors, publishers and booksellers were substantial. As Judge Jerome Frank observed in the lower court in Roth:

Fear of punishment serves as a powerful restraint on publication, and fear of punishment often means, practically, fear of prosecution. . . . If the definition of obscenity had a limited and fairly well known scope, that fear might deter restricted sorts of publications only. But on account of the extremely vague judicial definition of the obscene, a person threatened with prosecution ... [in respect to] almost any book which deals in an unconventional, unorthodox, manner with sex, may well apprehend that, should the threat be carried out, he will be punished. As a result, each prosecutor becomes a literary censor (i.e., dictator) with immense unbridled power, a virtually uncontrolled discretion. . . . Having no special qualifications for that task, nevertheless, he can, in large measure, determine at his will what those within his district may not read on sexual subjects. In that way, the statute brings about an actual prior restraint of free speech and free press which strikingly flouts the First Amendment. ${ }^{465}$

H.L. Mencken's complaint in 1917 is powerful and not atypical:

[A]s a practical editor, I find that the Comstocks, near and far, are oftener in my mind's eye than my actual patrons. The thing I always have to decide about a manuscript offered for publication, before ever I give any thought to its artistic merit and suitability, is the question whether

The Woman of Rome and Ernest Hemingway's For Whom the Bell Tolls, Censorship of Obscenity, supra note 451 , at 35 n.170.

464. See Literature, supra note 381, at 304-05, 310-11, 317. Among the books stifled were a collection of stories by Guy de Maupassant, Flaubert's Madame Bovary, William Faulkner's Pylon and Sanctuary, James M. Cain's Mildred Pierce and The Postman Always Rings Twice, Erskine Caldwell's Tobacco Road and A Place Called Estherville, John Dos Passos' The FortySecond Parallel, James T. Farrell's Young Lonigan and $A$ World I Never Made. Thomas Heggen's Mister Roberts, Pierre Louys' Aphrodite, W. Somerset Maugham's Fools and Their Folly and The Painted Veil, John O'Hara's Appointment in Samarra and Butterfield 8, Emile Zola's Nana and Theresa, Nelson Algren's The Man With The Golden Arm, Niven Busch's Duel in the Sun, C.S. Forester's The African Queen, Ernest Hemingway's A Farewell to Arms, James A. Michener's Tales of the South Pacific, Christopher Morley's Kitty Foyle, Irwin Shaw's The Young Lions, Natalit Anderson Scott's The Story of Mrs. Murphy, Ben Ames Williams' The Strange Woman, and James Warner Bellah's Ward 20. Also included were such nonfiction works as The Sexual Side of Marriage by M.J. Exner, M.D., How Shall I Tell My Child by Belle S. Mooney, M.D., and The Story of My Psychoanalysis by John Knight. Id. at 316-19.

465. United States v. Roth, 237 F.2d 796, 820-22 (2d Cir. 1956) (Frank, J., concurring) (footnotes omitted), affd., 354 U.S. 476 (1956). 
its publication will be permitted - not even whether it is intrinsically good or evil, moral or immoral, but whether some roving Methodist preacher, self-commissioned to keep watch on letters, will read indecency into it. Not a week passes that I do not decline some sound and honest piece of work for no other reason. I have a long list of such things by American authors, well-devised, well-imagined, well-executed, respectable as human documents and works of art - but never to be printed in mine or any other American magazine. It includes four or five short stories of the very first rank, and the best one-act play yet done, to my knowledge, by an American. All of these pieces would go into type at once on the Continent; no sane man would think of objecting to them; they are no more obscene, to a normal adult, than his own bare legs. But they simply cannot be printed in the United States, with the law what it is and the courts what they are. ${ }^{466}$

As for those who seek to challenge the system, "[a] publisher enmeshed in litigation in a number of jurisdictions - either directly or through the indemnities to booksellers that prevail in the book trade - soon finds himself facing legal expenses that make publication of the book unprofitable, and may even jeopardize his economic existence."467 And authors are even more vulnerable because

the author is ordinarily less able to bear the financial risk involved in a book that might be suppressed as obscene, and his contract with the publisher may even contain a clause that "The author hereby guarantees . . . that the work . . . contains nothing of a scandalous, an immoral or a libelous nature." The inevitable tendency is to make the serious author timid, to cramp his mind so that the books he is not afraid to write will fall far below the level of his abilities. And society, as a consequence of the anxiety to suppress smut at all costs, may lose the values of important literary, scientific, and educational contributions. In their place it may have a distorted literature, unfaithful to life, and perhaps even a blacking out of rational public discussion of social problems of immense public importance. ${ }^{468}$

The extent to which the availability of socially meaningful and valuable sex-related literature has become generally enhanced since the Court's 1957 pronouncement in Roth really needs no documentation for any observer. Writing in 1960, William Lockhart and Robert McClure reported that beginning in mid-1957, the National Organization for Decent Literature had begun "to decline as a potent force in the suppression of books and magazines." 469 Although they could not trace a direct causal relationship between .. : [the Court's] decisions and opinions and the changes in the censorship pattern . . . it is equally (1917).

466. H. MenCKen, Puritanism as a Literary Force, in A Book of Prefaces 197, 277

467. Jurisdictional Statement at 13, Memoirs, 383 U.S. 413 (1966).

468. Literature, supra note 381 , at 373 (footnotes omitted).

469. Literature, supra note 381, at 373. 
difficult to avoid drawing the inference that the new constitutional standards must have contributed to the relative freedom from censorship that now exists for both paper-bound and hard-cover books. ${ }^{470}$

Ten years later, Charles Rembar observed that

[1]iterary censorship has its most important impact . . . on the author. If he must keep an eye on the law, we are deprived of his best efforts. That perversion of the creative process ha[s] been stopped. . . . Since the time of Memoirs v. Massachusetts, there has been no high-court decision holding any book to be obscene. If there have been any contrary low-court decisions that remain unreversed, it is only because they have not been appealed. 471

Although several empirical studies found that the Justices' rulings had only minimal effect on the merchandising practices of booksellers and newsdealers, ${ }^{472}$ and that wholesalers and retailers - especially in smaller communities - often responded to the threats of censorship groups by withdrawing publications and succumbing to restrictions "that were not consistent with their usual practices or with Supreme Court decisions,"473 broader inquiry disclosed that "the Supreme Court's impact ha[d] been considerable."474 When "wholesalers or retailers perceived that they could defend themselves and took a stand against the censors, they frequently succeeded." 475 Often, prosecutors simply "refused to back the movement and told the censors that the materials they sought to suppress were not legally obscene," and "the censorship drive ceased when its members became convinced that convictions could not be obtained under the law or when court suits were dismissed or decided in favor of newsdealers."476 Moreover, because "the Supreme Court's decisions were economically beneficial to publishers,"477 they applied counterpressures on their distributors to market "the more popular girlie, romance, and adventure magazines,"478 which were now plainly protected constitutionally. 479

470. Censorship of Obscenity, supra note 451, at 7, 13 (footnotes omitted).

471. Rembar, Introduction to OBscenity: The Complete ORAL ARguments Before THE SupReme CluRt IN THE MAJOR ObscentTy CASES at xii (L. Friedman ed. 1970).

472. Levine, Constitutional Law and Obscene Literature: An Investigation of Bookseller Censorship Practices, in The IMPaCt of SuPReme Court Decisions: EMPIRICAL STudies 129, 138-41 (T. Becker ed. 1969) (noting, however, that the survey is inconclusive about the impact of legal norms of obscenity on bookseller behavior); Rodgers, Censorship Campaigns in Eighteen Cities: An Impact Analysis, 2 AM. PoL. Q. 371, 376 (1974).

473. Rodgers, supra note 472, at 378; see also id. at 379.

474. Id. at 385.

475. Id. at 380 .

476. Id. at 381 .

477. Id. at 382 .

478. Id. at 383 .

479. Indeed, an ancillary benefit to free expression noted was that "since erotic publications usually sold well and yielded a good profit" and "since many of the retailers and some of the 
Finally, there is no indication that the Burger Court's 1973 decision in Miller v. California ${ }^{480}$ - which promulgated a "substantially modified constitutional standard for separating obscenity from constitutionally protected material dealing with sex"481 - has resulted in any significant revival of the suppression of socially important communication. Because of the uncertainties created by Miller's somewhat relaxed first amendment strictures on the regulation of sexrelated expression, ${ }^{482}$ there were widespread predictions - in the phrase of one prosecutor - of "a totally different ball game."483 Within the year, however, the Justices' unanimous ruling in Jenkins $v$. Georgia ${ }^{484}$ that the film Carnal Knowledge "could not be found under the Miller standards to depict sexual conduct in a patently offensive way,"485 made clear that Miller had not eviscerated the Warren Court's protection of first amendment values in this area. Just as prior experience under the post-Roth system had indicated that successful censorship campaigns were very short-lived, ${ }^{486}$ "contrary to the expectations of civil libertarians," the Miller edict has had "relatively little effect." 487 An analysis of "censorship incidents" in American libraries showed that virtually the same number occurred in each of the years immediately preceding and following Miller. ${ }^{488}$ And a comprehensive empirical study of Miller's impact concluded that

both the number of jurisdictions conducting obscenity prosecutions and the total number of obscenity prosecutions have declined since the Court

wholesalers ran marginally profitable businesses," their continued ability to carry the less socially valuable publications averted their going out of business altogether. Id. at 382 .

480. 413 U.S. 15 (1973).

481. Lockhart, supra note 451 , at 544.

482. See Lockhart, supra note 451, at 544-57.

483. Project, An Empirical Inquiry into the Effects of Miller v. California on the Control of Obscenity, 52 N.Y.U. L. REv. 810, 858 (1977) (quoting Washington Post, June 23, 1973, \& B, at 9, col. 2). These expectations were given credence by stories immediately following the decision that Playboy and similar publications had been ordered off the newsstands in cities such as Ashland, Ohio, Charlottesville, Virginia, and Gulfport, Mississippi, U.S. NEWS \& WORLD REP., July 30, 1973, at 25, and that copies of Kurt Vonnegut's Slaughterhouse Five had been burned in Drake, North Dakota, TIME, July 8, 1974, at 56. Moreover, a majority of states adopted the new Miller definition either by statute or judicial construction. Project, supra, at 936 . However, the obscenity laws of some jurisdictions were invalidated by state or federal courts under the Miller standard. See, e.g., Stroud v. Indiana, 263 Ind. 3, 300 N.E.2d 100 (1973); Hamar Theatres, Inc. v. Cryan, 365 F. Supp. 1312 (D.N.J. 1973), vacated, 419 U.S. 1085 (1974). In addition, some states (including Iowa, Michigan, New Mexico, South Dakota and West Virginia), even after Miller, elected to regulate only the distribution of obscene materials to minors and unconsenting adults. Project, supra, at $864-65,937$.

484. 418 U.S. 153 (1974).

485. 418 U.S. at 161.

486. Rodgers, supra note 472 , at $374-75$.

487. TIME, July 8, 1974, at 56.

488. Shuman, A Geography of Censorship: A Regional Analysis of Recent Cases, 26 NEwsLETTER ON INTELLECTUAL FREEDOM 3 (1977). 
promulgated its new standard. This reduction occurred despite a finding that the quantity and the explicitness of hard core pornography have almost universally increased. In addition, the survey shows that neither nonprosecutory nor extra-legal methods have supplanted criminal prosecution as a regulatory tool. Rather, the study indicates, prosecutors in the years since Miller have accorded a lowered priority to obscenity prosecutions, and communities throughout the nation have evidenced a growing tolerance of sexually explicit materials. The empirical research shows, moreover, that both the nationwide conviction rate and the perceptions of prosecutors about the likelihood of conviction in obscenity trials in their own jurisdictions have remained constant since the RothMemoirs era. ${ }^{489}$

It is, of course, impossible to determine the precise influence that the Justices' rulings on sexual expression have had on shaping public attitudes and mores. It is equally difficult to ascertain the impact during the last three decades of such obviously important factors as demographic changes and the revolution that has occurred within the communications media generally. But there is no question that there has been a "drastic restructuring of the boundaries of permissible sexual speech."490 As a result, "even those dealers who voluntarily censor their stock increasingly accept literature which treats sex boldly" and the tolerance level of the censorship groups themselves has been markedly raised.491 This had led to "jury acquittals on materials that jurors until recently would have declared obscene," which, in turn has "influenced prosecutors to handle only cases involving particularly hard core materials."492 In all, the quantum of communication reaching the American public has increased enormously and the Court has undoubtedly played a major role.

\section{Group Legal Services}

Although a handful of group legal service plans had existed openly for over a half century, until the 1960's these enterprises (and other less visible ones, such as assistance by labor unions with respect to grievances against employers) had been stringently opposed by the professional ethics canons of the organized bar and regularly enjoined by state courts. ${ }^{493}$ This condition was drastically altered by a series of Supreme Court decisions articulating the constitutional right of individuals to band together to secure "meaningful access to the

489. Project, supra note 483, at 858-59.

490. Rodgers, supra note 472 , at 386.

491. $I d$.

492. Project, supra note 483, at 898.

493. See Schwartz, Group Legal Services in Perspective, 12 UCLA L. REv. 279 (1965) (foreword to The Availability of Counsel and Group Legal Services: A Symposium). 
courts."494 In addition to facilitating immeasurably the work of civil rights organizations such as the NAACP and ACLU,495 the Justices' newly formulated constitutional principle enormously spurred the growth of group legal service programs throughout the country.

Most importantly,

[a]s a result of the Court's decisions, the ABA abandoned its antagonism towards these plans and actively endorsed prepaid legal services. In 1970, it established a committee to study the area and, together with other organizations, it developed the first large scale plan which is still in existence today. Moreover, in 1975, the ABA removed almost all the ethical restrictions discouraging attorneys from participating in these plans by amending its Code of Professional Responsibility. ${ }^{496}$

Congress contributed its support by changing the Taft-Hartley Act to require employers to bargain in good faith over the creation of prepaid legal service plans ${ }^{497}$ and by affording favorable federal tax treatment to such employer-funded programs. ${ }^{498}$

Although the escalation of health plan costs and the generally adverse state of the national economy have deterred labor unions from pressing more aggressively in collective bargaining negotiations for inclusion of legal service programs as fringe benefits, ${ }^{499}$ the increase in the number of such plans has nonetheless been extremely encouraging. ${ }^{500}$ Nationally, it has been estimated that there are between 3,000 and 5,000 plans in operation, 501 "partly serving the legal needs of nine

494. United Transp. Union v. State Bar of Michigan, 401 U.S. 576, 585 (1971); see also United Mine Workers of Am., Dist. 12 v. Illinois State Bar Assn., 389 U.S. 217 (1967) (first and fourteenth amendments give union the right to hire attorneys on a salary basis to assist its members in the assertion of their legal rights); Brotherhood of R.R. Trainmen v. Virginia ex rel. Virginia State Bar, 377 U.S. 1 (1964) (union has a constitutional right to recommend particular attorneys to its members to handle their injury claims); NAACP v. Button, 371 U.S. 415 (1963) (NAACP has a constitutional right to provide legal counsel for its members in individual racial discrimination suits).

495. See NAACP v. Button, 371 U.S. 415 (1963); In re Primus, 436 U.S. 412 (1978).

496. Comment, Prepaid Legal Services: Obstacles Hampering Its Growth and Development, 47 FORDHAM L. REV. 841, $841-42$ (1979).

497. 29 U.S.C. $\S \S 186(a)$-(c) (1982).

498. See I.R.C. $\S \S 120,501(c)(20)$ (1982).

499. See L. Deitch \& D. Weinstein, Prepaid Legal Services - Socio-Economic IMPACTS 31-33 (1976) (adverse state of economy); Labor Letter, Wall St. J., Oct. 20, 1981, at 1, col. 5 (escalation of health plan costs).

500. For example, during 1982 the United Auto Workers included prepaid legal benefits in contracts with General Motors, Chrysler, and American Motors, and the Sheet Metal Workers obtained coverage for 6,000 members and their families. White, More Workers Gaining Prepaid Legal Insurance, 68 A.B.A. J. 1558, 1558-59 (1982). Moreover, whereas California had practically no such programs prior to 1969 , statistics for the five-year period beginning in July of that year showed nearly 700 group legal service arrangements by 1974 covering about 1.5 million people. Letter from Judith C. Cheney, Senior Legal Services Program Developer, State Bar of California, to the author (May 16, 1979).

501. See Saks, Insurance Trends and Topics, 9 EsT. PlaN. 248, 249 (1982); St. Antoine, Growth Patterns in Legal Services, AMERICAN FEDERATIONIST, Feb. 1976, at 19, 19. 
to ten million persons." 502 In addition, the nation's major insurance companies continue to increase their marketing efforts for the programs. ${ }^{503}$

Further, early data substantiate the view that group plans will respond to the problem of serious underutilization of lawyers' services in the United States. ${ }^{504}$ A careful empirical survey of the first major program of the 1970's (the Laborers Local No. 229 Legal Service Plan) ${ }^{505}$ disclosed that during its first year the number of members consulting attorneys was sixty percent greater than in the immediately preceding year and that a significant segment of these people "would not have seen a lawyer were it not for their membership in the plan."506 Further, the participating attorneys reported "that even when a member might have brought a problem to a lawyer anyway, the legal insurance plan enabled the member to get more extensive service." 507 The evidence also indicated that the program encouraged preventive legal assistance ("use of lawyers for advice only") 508 but showed "no signs of a flood of trivial matters being taken to lawyers." 509 When the plan's experimental phase was about to expire after three years, the union's rank and file - which had originally been only passively interested in it - "made it clear that they wished the program to continue and would contribute the funds necessary to support it." 510

Whether or not the promise of group legal services plans - whose childhood and adolescence is directly attributable to the Justices' parentage - will fully mature remains for the future. But there is reason to believe that the very optimistic predictions of the mid-1970's - that within a decade legal plans would serve as many as twenty million subscribers, comprising about seventy percent of all people who con-

502. Murphy, The Impact of Prepaid Legal Services Upon the Minority Bar, 5 BLACK L.J. 4, 11 (1970) (emphasis added to make clear that the typical plan does not provide comprehensive coverage but rather applies only to designated areas such as auto accidents, employment grievances, etc.); see also 68 A.B.A. J. 1559, supra note 500 (estimated 5.5 million persons and family members covered in 1983).

503. Saks, supra note 501, at 249.

504. See B. Curran \& F. Spalding, The Legal Needs of the Public 91 (1974) (more than $50 \%$ of respondents indicated interest in joining relatively low-cost prepayment or insurance type legal service plan); see also text at notes 1226-28 infra.

505. Generally known as the "Shreveport Plan," the program was a pilot project developed and partially funded by the ABA, Ford Foundation and Louisiana and Shreveport Bar Associations. Note, supra note 496 , at 842 n.9.

506. F. Marks, R. Hallauer \& R. Clifton, The Shreveport Plan: AN Experiment IN THE Delivery OF Legal SERvices 61-62 (1974) [hereinafter cited as F. MARKs].

507. Id. at 62 .

508. Id.

509. Id. at 65 .

510. Politz, Prepaid Legal Services: The Public Interest, 27 BAYLOR L. REv. 405,407 (1975). 
sult lawyers ${ }^{511}$ - may yet be realized at some time within the foreseeable future.

\section{Religious Freedom: Public Schools}

\section{Prayers}

Several surveys, undertaken shortly before the Court's decisions in the early 1960 's forbidding prayer and Bible reading ceremonies in the public schools, ${ }^{512}$ revealed that these activities were either permitted or required in seventy-five to eighty-five percent of the states, ${ }^{513}$ and actually in operation in about half of the school districts in the country. 514

There are at least two major difficulties - one qualitative and the other quantitative - in assessing the full impact on individual rights of the Justices' pronouncements. First, given their present state of learning, psychologists and sociologists cannot measure with any real accuracy the actual nature of the threat to religious liberty posed by sectarian practices in public schools, especially when dissenters are excused from participation. ${ }^{515}$ But despite this empirical uncertainty, the existence of the potential danger has been almost universally recognized. It has been widely observed that young people of minority religious groups, or with no religious affiliation at all, are extremely sensitive about conspicuously absenting themselves from religious exercises conducted by the majority and that there is a powerful, albeit subtle, pressure to conform. ${ }^{516}$ The emotional strain is very fre-

511. See L. DeIrCh \& D. Weinstein, supra note 499, at 103; Special CommitTeE oN Prepaid legal Services, American Bar Association, A Primer of Prepaid legal. SERvices 18 (P. Murphy ed. 1974); see also Project, An Assessment of Alternative Strategies for Increasing Access to Legal Services, 90 YALE L.J. 122, 146-55 (1980); Politz, supra note 510.

512. School Dist. of Abington Twp. v. Schempp, 374 U.S. 203 (1963); Engel v. Vitale, 370 U.S. 421 (1962).

513. R. Dierenfeld, Religion in American Public Schools 21 (1962); K. Dolbeare \& P. Hammond, The School Prayer Decisions 29 (1971).

514. Katz, Patterns of Compliance With the Schempp Decision, 14 J. PuB. L. 396, 405 (1965).

515. See Griswold, Absolute is in the Dark - A Discussion of the Approach of the Supreme Court to Constitutional Questions, 8 UTAH L. REV. 167, 177 (1963) (no danger if participation in ceremony is voluntary).

516. Social psychologists and sociologists have pointed out that children place great importance on how they are esteemed by their peers. J. BOSSARD \& E. BoLL, THE Sociology OF Child Development 411 (4th ed. 1966). The need to fit in with classmates is peculiarly strong. Id. at 428-29; see also Cushman, The Holy Bible and the Public Schools, 40 Cornel L L.Q. 475, 495 (1955). The "fear of being accused by the others of wanting to be 'different" " and the "very strong need to remain a member of one's group" are carried so far as to cause these children to do and say things in accordance with the majority that they are convinced are wrong, even with reference to simple perceptual materials. R. BERENDA, THE INFLUENCE OF THE GROUP ON THE JUDGMENTS OF CHILDREN 30, 14-33 (1950). This is particularly prevalent "where the situation is ambiguous and not very clear cut." Id. at 32. 
quently so great that it results in unwilling participation in ceremonies that are contrary to deeply held religious or conscientious precepts in preference to some amount of social ostracism. ${ }^{517}$ The option either to participate in the majority's religious worship or "to suffer the pain of psychic loneliness" has been described as forcing these immature students "to choose between equally intolerable alternatives." 18 Even religious educators have warned "that so-called voluntary exemption [from religious observances] does not overcome the compulsion exerted by majority behavior." 519

Second, because of the unwillingness of dissenters to come forward and identify themselves, ${ }^{520}$ the actual number of children whose religious liberty was infringed by these devotional exercises is highly uncertain. But given the broad heterogeneity of the nation's school population, the insuperable problems encountered by those who have attempted to fashion a religiously unobjectionable prayer, ${ }^{521}$ and the fact that no version of the Bible has been found acceptable even by all the major religious faiths, ${ }^{522}$ there is little doubt that the number was substantial.

Few decisions of the Supreme Court have generated greater political hostility and popular noncompliance than those proscribing prayer and Bible reading in the public schools, ${ }^{523}$ conditions that continue, albeit considerably abated, to the present. ${ }^{524}$ Nonetheless, a series of studies within the first few years of the rulings disclosed that,

517. See generally Choper, Religion in the Public Schools: A Proposed Constitutional Standard, 47 MINN. L. REV. 329, 343-46 (1963) (discussing indirect coercion as a violation of the establishment clause).

518. Address by Professor Robert Bierstedt, The Use of Public Schools for Religious Purposes, ACLU Biennial Conference, June 22, 1962, at 10 (available in American Civil Liberties Union Archives, Princeton University Library).

519. Committee on Religion and Public Education of the National Council of Churches of Christ, Relation of Religion to Public Education - A Study Document, INTL. J. ReligiouS Enuc., April 1960, at 21, 29.

520. See Choper, Comments, 23 J. Legal Educ. 143, 145-46 (1970).

521. Choper, supra note 517, at 368-69.

522. Id. at 372-75.

523. More than fifty proposed constitutional amendments were introduced in Congress within three days of the Engel decision, and following Schempp, by the close of the Eightyeighth Congress, more than one hundred fifty amendments had been introduced. Proposed constitutional amendments seeking to overturn these decisions have been introduced in Congress in every year since 1962 . The Senate has voted twice on such proposals, the House once. In each instance the measure was defeated.

Stone, In Opposition to the School Prayer Amendment, 50 U. CHI. L. REV. 823, 826 (1983); see also J. CHOpER, supra note 1, at 131, 147, 152, 158 \& citations therein; Beaney \& Beiser, Prayer and Politics: The Impact of Engel and Schempp on the Political Process, 13 J. PuB. L. 475, 477 83 (Engel), 486-503 (Schempp and proposed constitutional amendment) (1964).

524. See, e.g., Prayers in Schools Still at Issue 17 Years After Ruling, N.Y. Times, Dec. 26, 1980, at A20, col. 1. In 1982, the Reagan administration proposed a constitutional amendment to "remove the bar to school prayer established by the Supreme Court." President's Message to 
despite the unusually high degree of resentment and recalcitrance, these religious exercises had been either completely or almost completely eliminated in about two-thirds of all school districts in the nation. ${ }^{525}$ Indeed, "with the exception of the South, the practices had largely disappeared in public elementary schools by the academic year 1964-65."526 By 1973, the date of the most recent known survey, the national compliance level had reached ninety percent. ${ }^{527}$ Thus, despite persisting efforts to overturn the Court's edicts ${ }^{528}$ and sporadic episodes of outright defiance, ${ }^{529}$ in the main, voluntary acceptance by the vast percentage of the populace and vigorous policing of the exceptions by the state and federal judiciary ${ }^{530}$ have effectively extinguished these violations of freedom of individual conscience.

\section{Evolution}

In 1968, when the Court held in Epperson v. Arkansas ${ }^{531}$ that a statute forbidding public school teachers to teach Darwin's theory of evolution violated the first amendment's religion clauses, only two states - Arkansas and Mississippi - had 'such 'anti-evolution' or

the Congress Transmitting Proposed Legislation, 18 WeEkLY COMP. Pres. Doc. 664, 665 (May 17, 1982); see also ACLU, Civil Liberties Alert, No. 6, at 1 (July 1983).

525. See Reich, The Impact of Judicial Decision Making: The School Prayer Cases, in THE Supreme Court As Policy-Maker 44, 47 (D. Everson 2d ed. 1972) ("In 1960 forty-one percent (41\%) of the responding school districts reported devotional Bible reading; in 1966 thirteen percent (13\%) reported it"); Way, Survey Research on Judicial Decisions: The Prayer and Bible Reading Cases, 21 W. PoL. Q. 189, 191 (1968) ("By the academic year 1964-65 the situation had changed from the pre-1962 figure of 60 per cent of the classrooms saying prayers at sometime to only 28 percent."); Dolbeare \& Hammond, Inertia in Midway: Supreme Court Decisions and Local Responses, 23 J. LEGAL EDUC. 106, 110 (1970) ("about one-third of all districts were still not complying"); Katz, supra note 514, at 403 (19 of 25 states report that Bible reading has "completely" or "almost completely stopped"). It must be noted that this data is the product of self-reporting by school districts of their official policies (rather than observation of actual practices in individual classrooms) and thus may be less than wholly trustworthy.

526. Way, supra note 525, at 189.

527. Prayer: An Issue Without an Amen, N.Y. Times, Apr. 20, 1980 (Education) at 3, col. 1.

528. See notes 523-24 supra.

529. See Harris, A School Prayer Rebellion, S.F. Examiner, Mar. 21, 1982 (This World), at 22; High Court's Rulings Against School Prayer Are Often Violated, Wall St. J., Mar. 5, 1984, at 1, col. 1 .

530. See, e.g., Jaffree v. Wallace, 705 F.2d 1526 (11th Cir. 1983), cert. denied, 104 S. Ct. 1707 (1984); Lubbock Civil Liberties Union v. Lubbock Indep. School Dist., 669 F.2d 1038 (5th Cir. 1982), cert. denied, 459 U.S. 1155 (1983); Brandon v. Board of Educ., 635 F.2d 971 (2d Cir. 1980); DeSpain v. Dekalb County School Dist., 384 F.2d 836 (7th Cir. 1967), cert. denied, 390 U.S. 906 (1968); Stein v. Oshinsky, 348 F.2d 999 (2d Cir.), cert. denied, 382 U.S. 957 (1965); Johnson v. Huntington Beach Union High School Dist., 68 Cal. App. 3d 1, 137 Cal. Rptr. 43 (1977), cert. denied, 434 U.S. 877 (1977); Opinion of the Justices, 387 Mass. 201, 440 N.E.2d 1161 (Mass. 1982); Trietley v. Board of Educ., 65 A.D.2d 1, 409 N.Y.S.2d 912 (1978). Compare Duffy v. Las Cruces Pub. Schools, 557 F. Supp. 1013 (D.N.M. 1983), and Beck v. McElrath, 548 F. Supp. 1161 (M.D. Tenn. 1982), vacated, 718 F.2d 1098 (6th Cir. 1983), with Gaines v. Anderson, 421 F. Supp. 337 (D. Mass. 1976) (minute of silence at beginning of school day).

531. 393 U.S. 97 (1968). 
'monkey' laws on their books." 532 Moreover, there was good reason to believe that even in these jurisdictions the laws' impact was nonexistent. ${ }^{533}$

Despite the absence of formal enforcement of the two state laws, however, other evidence strongly indicates that the efforts of antievolution partisans - who caused twenty state legislatures to seriously consider banning Darwinism in the 1920 's $^{534}$ — had by no means failed. The fact is that during this time administrative regulations and public opinion were more effective than state legislation in restricting student knowledge about human biological history. For example, when the state legislatures in Louisiana, North Carolina and, originally, Mississippi declined to enact anti-evolution laws, the state school superintendents or boards of education, responding to clerical influence, accomplished the same result by administrative edict, as did local school boards in Portland, Oregon and Charlotte, North Carolina. 535

Further, studies from many parts of the country - including Atlanta, Chattanooga, Nashville and New York City - reported that teachers succumbed to informal pressures, with or without official threats of dismissal.536 A 1926 general survey of high school curricula found that

physics and chemistry received a disproportionate emphasis and that biological sciences were neglected. Even when biology was studied, the subjects, evolution and genetics, . . . were "practically ignored." . . . Even in 1933, a large number of questionnaires from the South and Border States reported that evolution cannot be taught. In some places it may be described as a theory refuted. Many teachers dare not even men-

532. 393 U.S. at 101.

533. In Arkansas, the Little Rock school administration "had inadvertently violated its own law . . . by revising public-school biology textbooks to include a chapter on evolution," NEwsWEEK, Nov. 25, 1968, at 37, and such textbooks had been "commonly used in Arkansas schools," TIME, Nov. 22, 1968, at 41 . Furthermore, there had never been a single recorded attempt to enforce the statute since its passage in 1928. In 1970, when the Mississippi Supreme Court, relying on Epperson, invalidated its 1926 statutes, the trial court had dismissed the challenger's complaint "because it did not charge that the defendants were making any effort to, or threatening, to enforce these laws." Smith v. State, 242 So. 2d 692, 694 (Miss. 1970). Indeed, in 1967, when a science teacher was discharged for violating Tennessee's similar 1925 enactment, made famous by the celebrated Scopes case, Scopes v. State, 154 Tenn. 105, 289 S.W. 363 (1927), the Tennessee legislature itself acted to repeal the prohibition. See Academic Freedom: Opposition to Ban on Teaching Evolution, 96 ScH. \& Soc. 329, 330 (1968).

534. 393 U.S. at 101 n.8.

535. H. Beale, Are American Teachers Free? 228-29 (1936). In Paducah, Kentucky, after proposed legislation was defeated in two consecutive years, two high school teachers were denied reappointment "because parents accused them of propounding evolution." Allen, The Anti-Evolution Campaign in America, 24 CURRENT Hist. 893, 894, 897 (1926). Similarly, in Portland, Oregon, "a manual training teacher was ousted . . . partly because he believed in evolution." H. BEALE, supra, at 231.

536. H. BEALE, supra note 535, at 234-37. 
tion the word "evolution." Some of them report that they use textbooks in which evolution is discussed, but that they have to skip over that section. ${ }^{537}$

A 1930 report concluded that the teaching of evolutionary principles has been quietly abolished throughout the greater part of the United States. . . . Nothing can be taught in 70 percent of the secular schools of this Republic today not sanctioned by the hosts of Fundamentalism. . . .

. . . During 1928-29 only three [anti-evolution] bills were presented. It is but natural that the general public should assume that "the fight is over, and science has won."

Nothing could be further from the truth. The Fundamentalists have merely changed their tactics. As one of their leaders has worded it, "We were too precipitate; we must go directly to the people themselves and not depend on the legislators." 538

There appears to be no comprehensive data as to whether these conditions persisted in succeeding decades. But such facts from the 1960's as the firing of an instructor in Tennessee, ${ }^{539}$ allegations that "numerous teachers" refused to teach evolution in Mississippi, 540 and the continuing controversy since the 1970's over the role of creationism theory in public school science courses ${ }^{541}$ plainly show that the issue is still very much alive.

It is clear that the Court's ruling in Epperson has not resulted in all public school pupils learning about Darwinism. For one thing, one of the fundamentalists' most successful avenues of attack - beginning in the 1920's and continuing into the 1970's - has been to influence biology textbook authors and publishers to omit or minimize discussion of evolution, ${ }^{542}$ a practice beyond the reach of the Justices' mandate. Moreover, although Epperson plainly forbids the use of any religiously motivated criteria in the appointment process and bars sanctions against instructors for teaching evolution in their classes, the difficulty in actually proving such matters probably limits the full effectiveness

537. H. BEALE, supra note 535, at 238.

538. Shipley, Growth of the Anti-Evolution Movement, 32 CURRENT HisT. 330 (1930).

539. See note 533 supra.

540. Smith v. State, 242 So. 2d 692, 694 (Miss. 1970).

541. See Note, Freedom of Religion and Science Instruction in Public Schools, 87 YALE L.J. 515, 515-18 (1978). Indeed, it is yet unknown whether the recent federal district court judgment, McLean v. Arkansas Bd. of Educ., 529 F. Supp. 1255 (E.D.Ark. 1982), which relied on Epperson to invalidate Arkansas' "Creation-science" law, will finally still the efforts in over 20 other state legislatures in which nearly identical bills have either been enacted or introduced. Religious Zeal, Religious Tyranny, N.Y. Times, Jan. 9, 1982, at A24, col. 1; Cookson, Professors Fight Creation Bill, N.Y. Times Higher Educ. Supp., June 5, 1981, at 6; O'Neil, Creationism, Curriculum, and the Constitution, 68 ACADEME, Mar.-Apr. 1982, at 21.

542. See Grabiner \& Miller, Effects of the Scopes Trial, 185 SCIENCE 832, 832-35 (1974); Evolution and Education (letters to the editor), 187 SCIENCE 389, 389-90 (1975). 
of this security. In addition, the fact that "teachers generally realize that nonconformity injures them and that conventional ideas and implicit obedience are the means to professional advancement," 543 undoubtedly results in many teachers continuing to follow the path of least resistance. But it is equally clear that the Court's decision has protected the jobs of those teachers unwilling to submit to subtle coercion and has bolstered the courage of others similarly inclined. Finally, the fact that contemporary creationists are now resigned to seeking equal time rather than outright abolition of evolutionary theory $^{544}$ must also plausibly be attributed at least in part to the operational success of the Court's strictures.

\section{E. Sexual Conduct: Contraception}

Still under the influence of the nineteenth century congressional Comstock Act, as of the early 1960 's, more than thirty states continued to impose various forms of restrictions or prohibitions in respect to contraception. ${ }^{545}$ The laws in some jurisdictions (such as Arizona, Mississippi and New Jersey) were effectively rendered meaningless by administrative practice or judicial interpretation. ${ }^{546}$ Despite repeated legislative efforts for liberalization, however, at least two states Connecticut and Massachusetts - flatly forbade all sale, distribution or advertisement of any device to prevent conception (Connecticut even making it a crime to use such articles for this purpose). 547 Wisconsin made it unlawful to transfer contraceptives to unmarried persons. ${ }^{548}$ Approximately one-third of the states permitted only physicians or licensed pharmacists to dispense contraceptives ${ }^{549}$ and more than half the states prohibited advertising, display or dissemination of information about them. ${ }^{550}$ These oppressive restraints on sexual freedom and family planning were all nullified by the Court

543. H. BEALE, supra note 535, at 589.

544. Wade, Creationists and Evolutionists: Confrontation in California, 178 SCIENCE 724, 724 (1972).

545. See C. Dienes, Law, Polmtics, and BirTh Control, app. B. (1972); National Center for Family Planning Services, Family Planning, Contraception and VolUNTaRy STERIlization: AN ANalysis of LaWs and Policies in the UNITEd STATES, EACH State AND JuRisdiction 58 (U.S. Dept. Health, Educ., \& Welfare, Pub. No. (HSA) 74 16001, 1972) [hereinafter cited as FAMILY PLANNING - 1972].

546. See Comment, The History and Future of the Legal Battles Over Birth Control, 49 CoRNELL L. Q. 275, 278 (1964); FAMILY PLANNING - 1972, supra note 545, at 60. 1980).

547. See Comment, supra note 546, at 278-79; Mass. Gen. Laws Ann. ch. 272, $\$ 21$ (West

548. See Wis. Stat. § 450.11(4) (1969).

549. See C. DIENES supra note 545, app. B, at 317-19.

550. See id. 
beginning with its decision in 1965 in Griswold v. Connecticut, ${ }^{551}$ followed in 1972 by Eisenstadt v. Baird, 552 and completed in 1977 by Carey v. Population Services International. ${ }^{553}$

Of course, the revolution in the law's attitude toward contraception that has taken place since the mid-1960's ${ }^{554}$ cannot be attributed exclusively to the Court's intervention. The process of change in public policy - stimulated particularly by political leaders and voluntary organizations (especially Planned Parenthood) as well as by many physicians and health professionals - had its origins several decades earlier. ${ }^{555}$ Despite the measured progress that preceded the Court's initial pronouncement, however, the Griswold ruling provided the catalyst for the gigantic reforms that occurred in its wake. ${ }^{556}$ Overall, in the six years following the Griswold benchmark, at least thirteen states repealed or substantially liberalized their anti-birth control laws. ${ }^{557}$

Probably the most profound effect of the Court's mandate was for the underprivileged. Even in Connecticut and Massachusetts, informed persons who could afford to consult private physicians within or without the state had no difficulty obtaining advice about contraception; ${ }^{558}$ the law was enforced effectively only against birth control clinics which, in the main, aided those "without either adequate knowledge or resources to obtain private counseling."559 The situation was similar in those states which permitted only doctors or druggists to dispense birth control devices and information. 560 For 1966, it was estimated "that women in the poverty sector experienced some

551. 381 U.S. 479 (1965).

552. 405 U.S. 438 (1972).

553. 431 U.S. 678 (1977).

554. See Family Planning - 1972, supra note 545, at 58.

555. See Jaffe, Public Policy on Fertility Control, 229 ScIEnTIFIC AM. 17, 17 (1973).

556. The day after the decision, the Chicago City Council's attorney ruled that Griswold "provided ample legal basis for approving the City's contract to purchase contraceptive supplies for the Board of Health." N. ST. JohN-STEvas, The Agonizing Choice: BirTh Control, RELIGION AND THE LAW 54-55 (1971). Nine days later, the New York legislature rescinded its 84-year-old ban on dissemination of birth control devices and information. See Ball, The Court and Birth Control, Commonweal, July 9, 1965 at 490, 493. Within less than a year of the Connecticut statute's invalidation, Massachusetts modified its absolute prohibition regarding contraception. See Medical WorLd News, Oct. 21, 1966, at 106.

557. See Family Planning - 1972, supra note 545, at 58.

558. See Back in Business, Newsweek, June 21, 1965, at 60.

559. Griswold v. Connecticut, 381 U.S. at 503 (White, J., concurring).

560. A report issued in 1965 by the Committee on Population of the National Academy of Sciences found that "The highest proportion of couples who never employ contraception or who have children beyond the number they intend is found among non-whites who live in the rural South or who have a rural southern background." The study suggested that most people who used contraception learned about it informally from friends or relatives or from family doctors, while "the disadvantaged groups . . . often do not have even these informal sources of information, and seldom consult private physicians." Birth Control: Academy Report Stresses Burdens of 
450,000 unwanted births."561 Thus, prior to Griswold, according to a leading manufacturer of oral contraceptives, "the birth control market was severely limited by economics." 562

Although the federal government had not been wholly unconcerned with this problem, its pre-Griswold activity had been only minimal. In the words of one National Institutes of Health official:

The honest fact is that until the Supreme Court finally moved, the federal government regarded birth control as a political hot potato. We had a few research studies going. But generally, the spending of the government for birth control research has been peanuts. As of Jan. 1, 1965, the total was $\$ 7$-million, spread out over 280 research projects. For that kind of money, you don't get in-depth research; you just get isolated statistical studies. 563

In the year following Griswold, HEW issued its first policy statement on family planning. President Johnson, in a special message to Congress, cited family planning as one of four health problems requiring particular attention. In 1967, Congress designated family planning for special emphasis in the poverty program and provided that at least six percent of appropriations for maternal and child health be devoted to family planning projects; it also amended the Social Security Act to require that the states offer family planning services to all public assistance recipients. In 1970, Congress passed the Family Planning Services and Population Research Act, authorizing \$382 million for programs of birth control services and research. By the mid-1970's, the national government had established an Office of Population Affairs, a National Center for Family Planning Services and a Center for Population Research, ${ }^{564}$ and in 1977 there were at least nine different federal programs dealing with family planning of some kind. 565

The family planning efforts of local government and privately financed agencies increased in comparable fashion. In 1960, no more than 150 public and voluntary health agencies operated birth control programs, ${ }^{566}$ and in 1965 it was estimated that only about 470,000 women in the United States received family planning assistance from

High Birth Rates Among Impoverished Here, 148 SCIENCE 1205, 1206 (1965). See also C. DIENES, supra note 545, at 258 n.14.

561. C. Dienes, supra note 545, at 257.

562. Population Control Takes a Forward Step, Business WeEK, June 19, 1965, at 108.

563. Id. at 108

564. Jaffe, supra note 555 , at $17,20$.

565. See Office for Family Planning, Family Planning, Contraception, VolunTARY STERILIZATION AND ABORTION: AN ANALYSIS OF LAWS AND Policies IN THE UNITED States, EACh StaTe AND JuRISDiction 4 (U.S. Dept. of Health, Educ., \& Welfare, Pub. No. (HSA) 79-5623, 1978) [hereinafter cited as Family PLANNING - 1978].

566. See Jaffe, supra note 555, at 21. 
these sources. ${ }^{567}$ But by 1972, "nearly 3,000 hospitals, health departments and voluntary agencies were providing services to an estimated 2.6 million women" 568 (up to 460,000 being never-married teenagers), ${ }^{569}$ and by 1975 this number had risen to more than 3.8 million. 570 In the decade between 1968 and 1978, the number of women counseled in contraception and family planning by federally funded clinics increased more than fivefold to approximately 4.5 million,, 571 and in the five years between 1971 and 1976, the percentage of "sexually experienced never-married women aged 15-19" who always used some form of contraception nearly doubled..$^{572}$

The impact of the Court's action in behalf of personal liberty may be seen most vividly in statistics revealing that "the incidence of unwanted pregnancy declined 36 percent between the first and second half of the 1960 s" $^{\prime 273}$ and that this reduction was greatest among blacks and women with little education. ${ }^{574}$ Indeed, the decline in fertility generally was "most pronounced among disadvantaged minorities and low income groups, and among the poorest women as classified by the poverty index." 575 Government expenditures for family planning services through Medicaid alone reached nearly $\$ 100$ million in 1976.576

\section{F. Right To Vote}

\section{Denials: In General}

In a series of decisions between 1965 and 1970, the Court firmly established the principle that most laws "distributing the franchise" 577 -i.e., granting "the right to vote to some bona fide residents of requisite age and citizenship" 578 but denying it to others - are presump-

567. G. Perkin \& D. Radel, Current Status of Family Planning Programs in the United States 14, 16 (Population Program, Ford Foundation 1966).

568. Jaffe, supra note 555, at 21.

569. Morris, Estimating the Need for Family Planning Services Among Unwed Teenagers, 6 Fam. Plan. Persp. 91, 96 (1974).

570. Cutright \& Jaffe, Family Planning Program Effects on the Fertility of Low-Income U.S. Women, 8 Fam. Plan. Persp, 100, 100 (1976).

571. HeW, Five-Year Plan for Family Planning Services and Population ReSEARCH 18 (Sept. 1979).

572. Zelnik \& Kantner, Sexual and Contraceptive Experience of Young Unmarried Women in the United States, 1976 and 1971, 9 FAM. Plan. PERsp. 55, 62 (table 9) (1977).

573. Jaffe, supra note 555 , at 21 .

574. Cutright \& Jaffe, supra note 570 , at 101.

575. Id.

576. Family PlanNing - 1978, supra note 565, at 125 (table 20).

577. Kramer v. Union Free School Dist. No. 15, 395 U.S. 621, 626 (1969).

578. 395 U.S. at 627. 
tively invalid. As a consequence, the barriers erected by a multitude of state provisions, disenfranchising massive numbers of voters, have been eliminated.

The first important pronouncement was Carrington v. Rash, 579 invalidating a Texas constitutional provision that denied the vote in state elections to all persons who came to Texas as members of the military so long as they remained in the armed service. Although only about a half dozen states had similar absolute bans, ${ }^{580}$ approximately half the states applied the prohibition to any such person living on a military base, ${ }^{581}$ thus " "[f]encing out' from the franchise" 582 a notable segment of the population.

Beyond military personnel, Carrington's most important consequences have been for students residing at the colleges and universities that they attend. As of the early 1970's, "only six states . . . permitted students to register in their college town." 583 The political implications of the contrary rule, ordained by Carrington, ${ }^{584}$ are apparent, given the many college communities throughout the nation in which student voting sentiment is potentially dispositive and the fact that college students vote at a substantially higher rate than their nonstudent counterparts. ${ }^{585}$

Probably the Court's most significant decision on the subject was City of Phoenix v. Kolodziejski, ${ }^{586}$ holding that rules limiting the ballot to property taxpayers in elections concerning various forms of state and local indebtedness violated equal protection. Although the requirement of property ownership as a qualification for voting gener-

579. 380 U.S. 89 (1965).

580. Brief for Respondent at 36-38, Carrington v. Rash, 380 U.S. 89 (1965).

581. A. Reitman \& R. Davidson, The Election Process: Voting Laws and ProceDURES 13 (1972).

582. 380 U.S. at 94.

583. A. Rerrman \& R. DAvidson, supra note 581, at 16 (Alaska, Colorado, Nebraska, Utah, Washington, and Wisconsin).

584. See, e.g., Whatley v. Clark, 482 F.2d 1230 (5th Cir. 1973), cert. denied, 415 U.S. 934 (1974); Auerbach v. Kinley, 499 F. Supp. 1329 (N.D.N.Y. 1980); cf. Hershkoff v. Board of Registrars, 366 Mass. 570,321 N.E.2d 656 (1974).

585. R. WOLFINGER \& S. RosensTONE, Who Votes? 56-57 (1980). "In Champaign, Illinois, for example, 16,000 votes are cast at a usual election - the same as the number of students who live at the University of Illinois." A. REITMAN \& R. DAVIDSON, supra note 581, at 15 n.*. Indeed, in 1978, "student enrollment exceed[ed] the incumbent's margin of victory in 91 U.S. Congressional districts in 33 states." A. Levine, When Dreams aND Heroes Died: A PORTRAIT OF TODAY'S COLLEGE STUDENTS 34 (1980); For discussion of continuing official barriers to students voting in campus communities, see Palmer, Student Groups Join in Proclaiming a 'Right-10-Vote Emergency,' CHRON. OF HIGHeR Educ., June 20, 1984, at 15.

586. 399 U.S. 204 (1970); see also Cipriano v. City of Houma, 395 U.S. 701 (1969) (restricting franchise to property tax payers in elections on revenue bonds violates the Equal Protection Clause). 
ally, which was dominant at the time the Constitution was ratified, had disappeared almost entirely during the Jacksonian era, 587 as of 1970 nearly one-third of the states continued to impose such a condition in order to vote on some bond issues. ${ }^{588}$ The potential impact of the enfranchisement of all those citizens who were subject to the benefits and burdens of such decisions ${ }^{589}$ may be strikingly illustrated by a 1967 election in Houma, Louisiana, in which an issuance of utility revenue bonds was approved by a vote of 1828 to 896 property owners while "6,926 duly qualified and registered non-property tax paying voters" 590 were forbidden to participate.

The Court's rulings on whether "residents of requisite age and citizenship"591 may be excluded from voting in the more than 20,000 "special purpose districts" in the United States"592 have drawn a somewhat ambiguous line. ${ }^{593}$ But since school districts and junior college districts have been specifically held to be within the protective boundaries, ${ }^{594}$ and since these comprise about eighty percent of the "special purpose districts," 595 the broad effect of the Court's mandate has been manifest here as well. Finally, other decisions of the Justices - and of lower courts following their lead - have extended the right to vote to such previously disenfranchised groups as those living on federal enclaves within the states 596 and arrested persons being detained for trial. 597 (1918).

587. See generally K. PORTER, A History OF SUFFRAGE IN THE UNITED STATES 77-111

588. 399 U.S. at 213 n.11; see also Recent Developments, Voting - Property Qualifications for Voting in Special Purpose Districts: Beyo::d the Scope of "One Man-One Vote," 59 CORNELl L. REv. 687, 691 n.21 (1974).

589. See 399 U.S. at 209-12.

590. Appellant's Jurisdictional Statement at 5, Cipriano v. City of Houma.

591. Kramer v. Union Free School Dist. No. 15, 395 U.S. 621, 627 (1969).

592. Bureau of the Census, U.S. Dept. of Commerce, 1967 Census of GovernMENTS, FinANCES OF Special. DisTricts, Vol. 4, No. 2, at 1 (1967).

593. See Ball v. James, 451 U.S. 355 (1981) (water district election law apportioning voting power according to number of acres owned does not violate equal protection clause); Salyer Land Co. v. Tulare Lake Basin Water Storage Dist., 410 U.S 719 (1973) ("water storage district" election not subject to judicial scrutiny when benefits and burdens of election fali disproportionately on landlords and assessments on land sole means by which expenses paid). But see Johnston v. Lewiston Orchards Irrigation Dist., 99 Ida. 501, 584 P.2d 646 (1978).

594. Hadley v. Junior College Dist., 397 U.S. 50 (1970); Kramer v. Union Free School Dist. No. 15, 395 U.S. 621 (1969).

595. J. Bollens, Special District Governments in the United States X (1957).

596. Evans v. Cornman, 398 U.S. 419 (1970). Compare the long line of contrary state rulings in Annot., 34 A.L.R.2d 1193-202 (1954).

597. O'Brien v. Skinner, 414 U.S. 524 (1974); Arlee v. Lucas, 55 Mich. App. 340, 222 N.W.2d 233 (1974). 


\section{Poll Taxes}

Historically, substitution of poll taxes for property-ownership requirements for voting was intended to expand the franchise. ${ }^{598}$ But when the eleven states of the old Confederacy enacted these levies during the post-Reconstruction era, ${ }^{599}$ their purpose was rather to deny the ballot either to racial and ethnic minorities, or poor whites. ${ }^{600} \mathrm{Be}$ cause of the plethora of other antivoting devices, both blatant and subtle, directed particularly against racial minorities, it is difficult to determine precisely just how successful this effort was. Thus, although statistics in 1960 showed that a higher percentage of blacks were registered to vote in those southern states with poll taxes than in those without them, ${ }^{601}$ it has been observed that if the numerous extralegal "restraints on Negro voting disappeared overnight, the economic burden of the tax would be a real obstacle to voting by poorer Negroes." 602 Further, data from various periods strongly imply that the poll tax did pose a significant deterrent to exercise of the franchise. ${ }^{603}$

By 1966, when the Court, in Harper v. Virginia State Board of Elections, ${ }^{604}$ invalidated poll taxes, only four states - Alabama, Mississippi, Texas and Virginia - continued to exact them. ${ }^{605}$ The evidence of their inhibiting effect on voting, although again less than conclusive (especially because of the contemporaneous influence of the Voting Rights Act of 1965 and sustained black voter registration drives) is nonetheless impressive. The data that perhaps best isolates the deterrent impact of these poll taxes from other disincentives to voting may be found by comparing the percentage of eligible citizens casting ballots in the 1964 presidential election to that in 1960. The

598. See Nimmo \& McCleskey, Impact of the Poll Tax on Voter Participation: The Houston Metropolitan Area in 1966, 31 J. PoL. 682, 682 (1969).

599. Id.

600. See H.R. REP. No. 439, 89th Cong., 1st Sess. 19-22 (1965); H.R. ReP. No. 1821, 87th Cong., 2d Sess. 3 (1962); J. PerRy, Democracy Begins at HOME 205 (1944); $c f$. F. OGDEN, The POLl TAX IN Th . SOUTH 144-68 (1958) (study of comparison of poll tax rates of payment showed fewer voters in counties with a dense population, a high degree of urbanism and a high percentage of nonwhites).

601. See U.S. NewS \& WorLd REP., Mar. 28, 1960, at 40, 41.

602. V. KEY, supra note 87 , at 618 (1949).

603. For example, in 1897, prior to Louisiana's imposition of the tax, 130,300 blacks were registered to vote; this number decreased to 5,300 in 1900 and to 1,340 in 1904. After Louisiana repealed its poll tax in 1934, with the support of Huey Long's neo-Populist surge, the average rate of eligible voter participation in senatorial primaries rose from $31 \%$ to $47 \%$ and in gubernatorial primaries from $40 \%$ to $61 \%$. In the presidential election following Florida's elimination of its levy in 1937, the vote increased by $46 \%$. And when Georgia rescinded its poll tax in 1945 , the eligible voter turnout nearly doubled. See Douglas, Should State Poll Tax Laws As Applied to Federal Elections Be Uniformly Abolished - Pro, CoNG. Dig., May 1962, at 144-46.

604. 383 U.S. 663 (1966).

605. 383 U.S. at 666 n.4. 
1964 election, which obviously preceded the Voting Rights Act of 1965, was the first in which the twenty-fourth amendment's bar on poll taxes in federal elections was operative. In thirty-two states the percentage voting declined between 1960 and 1964; it increased in only twelve states, three of which were relatively insignificant; of the nine remaining states with an increase, five (the four still left in Harper plus Arkansas) made payment of a poll tax a prerequisite to voting in 1960.606

The most detailed information on Harper's consequences comes from Texas. After a three-judge federal court declared the state's poll tax unconstitutional a month before the Supreme Court's Harper ruling, ${ }^{607}$ a special session of the Texas legislature "whipped through an inhospitable new registration law which, because it contained many restrictive features, was called the "Mississippi plan." "608 Although the law afforded only fifteen days for nonregistrants to enroll, and although the Voting Rights Act of 1965 had already been in effect for over half a year, more than 600,000 Texans registered, thereby enlarging the electorate by twenty-five percent. ${ }^{609}$ In local elections held the following month, blacks won office in five towns; in four of them, it was the first time a black had been elected since a poll tax requirement for voting had been adopted 65 years earlier.610 In the Democratic primary held one month later, three blacks (including Barbara Jordan) were nominated to the legislature, which had not had a single black legislator in the twentieth century. ${ }^{611}$ Notable results also occurred in the other states whose poll taxes were disapproved in Harper. ${ }^{612}$ Of course, as noted earlier, the abolition of the poll tax was but one of the

606. Brief of the United States as Amicus Curiae, app. B, at 38, 47-49, Harper v. Virginia Bd. of Elections, 383 U.S. 663 (1966).

607. United States v. Texas, 252 F. Supp. 234 (W.D. Tex.), affd, 384 U.S. 155 (1966).

608. Nation, Apr. 4, 1966, at 381.

609. N.Y. Times, Apr. 10, 1966, at 60 , col. 6 .

610. Id.

611. N.Y. Times, May 9, 1966, at 20, col. 3. A careful study in Houston (the South's largest city), which experienced the same $25 \%$ increase in registration despite the absence of any particularly salient election contest, Nimmo \& McClesky, supra note 598, at 684-85, 687, specifically addressed the ethnic minority issue. It found that "[t]he most striking feature" of the poll tax system "was the exclusion of the Mexican-Americans . . . for they constituted 5.6 percent of the potential voters but only 1.6 percent of the poll-tax payers." Id. at 688 . During the 15-day enrollment period, there was a "spectacular increase in Mexican-American registration from 1.6 percent of total paid registrants to 7.2 percent of the free registrants." Id. at 692 .

612. In Virginia, four months after the court's mandate, Rep. Howard W. Smith, then one of the "top-ranking fiscal and racial conservatives in Congress and in Virginia's once-unbeatable Democratic oligarchy," suffered a narrow defeat. This was attributable to "a combination of factors - his age, the reapportionment of his district" and his opponent's "vigorous and unabashed appeal to new Negro voters . . . recently freed of Virginia's rigorously enforced poll tax." N.Y. Times, July 13, 1966, at 1, col. 4; 26, col. 3. In Alabama, it was observed that 
many factors - and, indeed, not the major one - that produced many of these results. But, as suggested by the more causally related evidence described above, its contribution cannot be slighted.

Finally, it may be-as concluded in the Houston study - "that the end of the poll-tax system [had itself] failed to revolutionize voter turnout" 613 or election results, for substantial numbers of persons who registered after the levy's demise actually failed to vote in the immediately succeeding election. ${ }^{614}$ Nonetheless, in Houston, there was a fifteen percent increase in those who went to the polls, and "we know from past experience that a newly enfranchised electorate responds but slowly to its opportunities; it takes time to throw off the habits and attitudes associated with nonparticipation (low levels of interest in politics, ignorance of polling procedures, lack of ties to political organizations, etc.)." 615 In all, while it is surely possible that the poll tax would have eventually fallen into disuse by its own weight, it is quite plain that the Court's action against it has had a marked effect in advancing the constitutional right to vote of the economically disadvantaged.

\section{Dilution: Apportionment}

Although critics of legislative malapportionment predicted revolutionary political and social changes as a result of the Supreme Court's one person-one vote mandate ${ }^{616}$ - indeed, Chief Justice Warren identified the reapportionment decisions as the most significant of his tenure $^{617}$ - in the first half decade after Reynolds v. Sims, ${ }^{618}$ despite complying alterations in virtually every state legislative and congres-

\footnotetext{
"thousands of Negroes registered under the Voting Rights Act of 1965 ha[d] not paid the poll tax in anticipation of the court's ruling" in Harper. TIME, Apr. 1, 1966, at 25B.

Six years after Harper, it was reported that in Mississippi

black voter registration has increased from 28,500 in 1964 to over 300,000 today. Ten years ago there were no black elected officials in Mississippi. Today, Mississippi, with a total of 128 , leads the southern states with the largest number of black officeholders. In the Mississippi general elections of 1971, a record number of 309 black candidates sought public office at all levels . . . [and] the victories of 72 black candidates at the beat and county levels represented a net increase of 34 new black officials. Elected to public office in 1971 were 7 members of county boards of education, 16 members of election commissions, 1 state representative, 5 county-wide officials (including a tax assessor and a circuit clerk), and 46 county beat-level offices.

Lewis \& Allen, Black Voter Registration Efforts in the South, 48 NOTRE DAME LAw. 105, 115 (1972).

613. Nimmo \& McClesky, supra note 598, at 698 .

614. Id. at 696-97.

615. Id. at 699 .

616. See generally The Politics of Reapportionment (M. Jewell ed. 1962).

617. N.Y. Times, June 27, 1969, at 1, col. 5.

618. 377 U.S. 533 (1964).
} 
sional district in the nation, ${ }^{619}$ the studies undertaken came to conflicting conclusions as to the effect of reapportionment on state policy and the extent to which reapportioned legislatures were more likely than malapportioned ones to expend funds, respond to urban needs and have a competitive political system. ${ }^{620}$ Subsequent empirical efforts, however, have vindicated the criticism ${ }^{621}$ that those who had earlier discounted the political and policy consequences of reapportionment had failed to prove their case. Several phenomena have been suggested as contributing to the initial skepticism and delayed effectiveness of reapportionment - among them being "that survival instincts among state legislators are very strong, and that in the process of reapportionment key incumbents would be protected and would likely retain positions of power," 622 and that, in any event, changes in state legislative decisionmaking tend to be incremental rather than dramatic. ${ }^{623}$ But whatever the dynamics, a large number of careful studies since 1970 consistently demonstrate the consequential differences that reapportionment has produced.

The clearest change was the one most expected: from Alaska to Wyoming there were immediately observable marked increases in urban and suburban representation with resulting diminished influence of rural interests. ${ }^{624}$ Although, as indicated above, pervasive substantive reversals did not occur, ${ }^{625}$ various inquiries disclosed that many issues were affected by implementation of the Court's edict. ${ }^{626}$ In a "longitudinal 50-state study of the impact of reapportionment on fiscal

619. See McKay, Reapportionment: Success Story of the Warren Court, 67 Mich. L. REv. 223, 229 (1968).

620. For a collection and appraisal of these studies, see Bicker, The Effects of Malapportionment in the States - A Mistrial, in REAPPORTIONMENT IN THE 1970's, at 151 (N. Polsby ed. 1971).

621. $I d$.

622. Cho \& Frederickson, The Effects of Reapportionment: Subtle, Selective, Limited, 63 NATL. CIV. REV. 357, 359 (1974); see also T. O'ROURKE, THE IMPACT OF REAPPORTIONMENT 150 (1980).

623. Cho \& Frederickson, supra note 622 , at 360.

624. See T. O'RourKe, supra note 622, at 149; IMPACT OF REAPPORTIONMENT ON THE ThirTEen Western States 45, 66, 87, 173, 179, 202, 236, 304, 309 (E. Bushnell ed. 1970) [hereinafter cited as IMPACT]; Erickson, The Partisan Impact of State Legislative Reapportionment, 15 MIDWEST J. Pol. ScI. 57 (1971); Robeck, Urban-Rural and Regional Voting Patterns in the California Senate Before and After Reapportionment, 23 W. POL. Q. 785, 794 (1970).

625. See note 623 supra and accompanying text. See also T. O'ROURKE, supra note 622, at 151; Robeck, supra note 624, at 794.

626. Thus, one early nationwide analysis found that "[w]hile the results of reapportionment are not . . . either uniform in every state or very dramatic in any state, they do suggest that legislative apportionment is one important component in explaining changes in state policies during the late 1960's." Hanson \& Crew, The Effects of Reapportionment on State Public Policy Out-Puts, in THE IMPACT OF SUPREME COURT DECISIONS 155, 160 (T. Becker \& M. Feeley eds. 1973). 
and non-fiscal policy . . . it was concluded, by using an elaborate series of multiple linear regression equations, that reapportionment is having a generally democratizing impact on state policy."627 In a survey in 1979 of all incumbent state senators who had been in office in 1967, nearly four out of five respondents perceived a more liberal direction in lawmaking over that period of time.628 And, "the large number of single state studies conclude[d] that reapportioned states became more responsive to urban needs and their spending patterns became more liberal." 629 More specifically, "[1]egislative responsiveness was significantly influenced by reapportionment in politically and socially critical policy issues such as firearms control and civil rights ... [although] not in morally controversial issues such as divorce and abortion legislation." 630

As for state fiscal policies, marked adjustments were observed in both the level and direction of expenditures. "Using a before-and-after test," the two comprehensive nationwide surveys "found that the rate of increase was significantly greater in reapportioned than in non-reapportioned states." 631 Although the earlier of the studies discerned that, because of population movement from the inner cities, ${ }^{632}$ spending "increases due to reapportionment were more likely to have benefitted suburban interests than the central cities," 633 there was no disputing the general reversal of emphasis on rural concerns. Thus, with the exception of aid to schools, the later fifty-state analysis reported that metropolitan-nonmetropolitan disparity was significantly reduced by reapportionment in total state aid and welfare spending. . . ${ }^{634}$ Those states whose legislatures were reapportioned earlier spent more for general welfare and urban-related functions such as public welfare, public health and hospitals, and less for highways, [and] state aid to local governments in general. 635

A more recent six-state study confirmed the broad conclusion, but specifically noted reapportionment's greater impact in those states whose central cities (rather than suburbs) had been more severely under-

627. Cho \& Frederickson, supra note 622, at 357-58.

628. Saffell, Reapportionment and Public Policy: State Legislator's Perspectives, 9 POLY. STUD. J. 916, 922, 928 (1980-81).

629. Id. at 921.

630. Cho \& Frederickson, supra note 622 , at 360. 358.

631. Hanson \& Crew, supra note 626, at 172; see also Cho \& Frederickson, supra note 622, at

632. Hanson \& Crew, supra note 626 , at 170.

633. Id. at 172.

634. Cho \& Frederickson, supra note 622 , at 361.

635. Id. at 359. 
represented in the old system. ${ }^{636}$ Indeed, the overwhelming majority of state senators surveyed in 1979 responded that the elimination of malapportionment produced more state aid to urban areas. ${ }^{637}$

Less prominent but nonetheless measurable effects, in regard to the election of racial and ethnic minority legislators and more balanced political party representation, have also been recorded despite the acknowledged increase in various forms of gerrymandering allegedly aimed in the opposite direction. ${ }^{638}$ Although it is impossible to demonstrate a direct causal relationship, in the first decade after Baker $v$. Carr, ${ }^{639}$ ten additional congressional districts came to be represented by blacks and the number of black state legislators increased from 94 to 238.640 As for political parties, reapportionment was found to be the cause of "the emergence of viable two-party competition for legislative control . . . [in] Tennessee and, to a lesser extent, Kansas,"641 and to have resulted in greatly improved proportional equity between Democrats and Republicans in the New York legislature. 642

Overall, "[a]1though reformers in the early 1960s may have overstated the anticipated benefits of reapportionment, much of what they have predicted has occurred. Empirical studies in the 1970 s consistently have concluded that state legislatures have become more respons[ive] to majority will,"643 and "the impact of reapportionment

636. T. O'RouRKE, supra note 622 , at $151,156$.

637. Saffell, supra note 628, at 929.

638. See, e.g., Cho \& Frederickson, supra note 622, at 362; Elliott, Prometheus, Proteus, Pandora, and Procrustes Unbound: The Political Consequences of Reapportionment, 37 U. CHI. L. REv. 474 (1970); Smith, The Failure of Reapportionment; The Effect of Reapportionment on the Election of Blacks to Legislative Bodies, 18 How. L.J. 639 (1975).

639. 369 U.S. 186 (1962).

640. Smith, supra note 638, at 661, 674. More pointedly, in California

[a] Negro was elected to the senate for the first time in 1966, and he, four Negro assemblymen, and one Negro assemblywoman served in the 1969 legislature. A Mexican-American was elected to the assembly in 1968. Although several persons of Mexican descent have been elected to the California Legislature since 1850, he was the lone representative of the state's largest ethnic minority in either house in 1969. Two persons of Asian descent, an assemblywoman and a senator, were elected in 1966 and reelected in 1968. It is worthwhile to note that all these minority-group legislators were elected from urban districts, most of which were attributable to the 1965 reapportionment.

Gallagher \& Weschler, California, in IMPACT, supra note 624, at 71, 87. In Nevada, the election of the first black legislator in the state's history "was caused by the increase in seats in Las Vegas, which has a substantial Negro enclave, and the consequent enlarged opportunity for a minority candiate." Bushnell, Nevada, in IMPACr, supra note 624, at 185, 200. In Kansas, New Jersey and Tennessee, "an increase in the number of black legislators as a result of greater central city representation and subdistricting of central city counties" was reported. T. O'RouRKE, supra note 622 , at 149.

641. T. O'RourKE, supra note 622, at 149.

642. Scarrow, The Impact of Reapportionment on Party Representation in the State of New York, 9 PoLY. STud. J. 937, 944 (1980-81).

643. Saffell, supra note 628, at 922. 
apparently has been more extensive in those states more severely malapportioned prior to Baker and Reynolds than in states less severely malapportioned."644 Moreover, given the operative dynamics of gradualism described above, there is good reason to believe that continued change is the path of the future.

Because the Supreme Court's rulings in Baker, Reynolds, and subsequent cases mandate periodic redistricting to bring legislative districts in line with population changes, legislative apportionment in the coming years can provide little protection to those political interests which suffer a declining population base. This situation is in sharp contrast to the half century before Baker when malapportionment entrenched conservative and rural elements in the face of adverse population trends. ${ }^{645}$

Finally, and probably most importantly, the Justices' rejection of the previous system cogently repaired a crucial void in American democratic society. For, as Joseph Bishop succinctly put it, "legislative malapportionment had become a scandal and an affront to democracy."646 By actively furthering - although by no means insuring or seeking fully to insure - the democratic ideal of majority rule (as well as that of equality), the Court successfully exercised its power on behalf of the majority of citizens and voters in the nation, mostly urban dwellers, whose political influence had been seriously diluted by entrenched minority interests. At least when dealing with the federal and state legislatures, only the Court seemed to be capable of improv. ing the majoritarian quality of the political process. ${ }^{647}$

Granting that the full complement of apportionment decisions shored the theoretical foundation of the political process at many levels of American government, it has by no means provided for the elimination of every influential anti-majoritarian device. But the formal representative institutions with which the Court dealt were perversely incompatible with the democratic ideal because they afforded no meaningful protection to individual constitutional rights - at least as commonly perceived - and were indeed able affirmatively to promulgate laws opposed by the majority of the constituency as a whole.

644. T. O'ROURKE, supra note 622 , at 156.

645. Id. at 159-60.

646. Bishop, The Warren Court Is Not Likely to Be Overruled, in THE SUPREME CouRT UNDER EARL WARREN, supra note 29, at 93, 98.

647. It is true that, in the past, legislators who had been the beneficiaries of existing arrangements for voting had moved on their own initiative to enfranchise additional groups of citizens (such as women). But the electoral effect of extending voting rights to such persons who were scattered throughout the population was much less certain than that of equalizing legislative districts. Because of the paralytic nature of malapportionment - whose cure would guarantee some lawmakers the loss of their seats and would imperil those of many others - there was no reason to believe that a nonjudicial remedy would ever be forthcoming. 


\section{Ballot Restrictions}

Whether the Supreme Court's 1968 ruling in Williams v. Rhodes ${ }^{648}$ - finding that Ohio's requirements for new political parties to obtain a place on the state's election ballot were unduly burdensome - will, as then predicted, be "a landmark decision in terms of the future of American political institutions" 649 has yet to be confirmed. The diversity of state rules that independent candidates or those of nonestablished parties had to meet in order to gain a ballot position was overwhelming, ${ }^{650}$ and Ohio's restrictions - enacted in 1948 specifically to thwart the presidential aspirations of those like Henry Wallace 651 — "stood at the extreme even among those statutes thoroughly designed to discourage qualification."652 Further, as of the end of 1984, only three times since Williams has a full opinion of the Supreme Court rejected a nonfinancial state restriction on ballot access - and in Moore v. Ogilvie ${ }^{653}$ and Illinois Board of Elections $v$. Socialist Workers Party ${ }^{654}$ the decisions concerned relatively narrow impediments. ${ }^{655}$ Moreover, in several subsequent cases, the Court has held that a number of state regulations demanding that minor parties and independent candidates demonstrate specified support before being listed on the ballot were not unconstitutionally burdensome. ${ }^{656}$ And a substantial number of lower courts have followed this lead by sustaining a variety of similar state provisions. ${ }^{657}$ Consequently, Williams' impact has been less than revolutionary.

Nonetheless, the Court's holdings and dicta concerning the constitutional limits of state qualification rules have wrought important change. Federal courts in several states have struck down laws similar

648. 393 U.S. 23 (1968).

649. Ireland \& Ireland, The Political Arena: Revolution in the Barriers to Entry, 1970 J. L. \& SOC. ORD. 213, 214.

650. See Ireland \& Ireland, supra note 649, at 215-18; Note, The Uncertain Impact of Williams v. Rhodes on Qualifying Parties for the Ballot, 6 HARv. J. ON LEGIS. 236, 242-44 (1969).

651. See Williams v. Rhodes, 393 U.S. 23, 47 n.9 (1968) (Harlan, J. concurring).

652. Note, supra note 650 , at 241.

653. 394 U.S. 814 (1969) (Illinois required independent candidates to submit 200 signatures from each of 50 counties).

654. 440 U.S. 173 (1979) (Illinois required new political parties and independent candidates to submit more signatures to qualify for local elections than for statewide elections).

655. See also McCarthy v. Briscoe, 429 U.S. 1317 (1976) (opinion of Powell, J., as Circuit Justice) (Texas required that a presidential candidate be a member of a political party to secure a place on the ballot). For the third, and the most recent decision, see Anderson v. Celebrezze, 460 U.S. 780 (1983) (invalidating an early filing deadline for presidential candidates), discussed at note 664 infra.

656. American Party of Texas v. White, 415 U.S. 767 (1974); Storer v. Brown, 415 U.S. 724 (1974); Jenness v. Fortson, 403 U.S. 431 (1971).

657. See cases collected in 43 UMKC L. REV. 127, 137 n.68 (1974). 
to the one invalidated in Moore v. Ogilvie. ${ }^{658}$ In at least four other states, lower federal courts, relying principally on Williams $v$. Rhodes, ${ }^{659}$ struck down other overly demanding restrictions for minor parties. 660 Most significantly, within two years of the Court's pronouncement in Storer v. Brown that independent candidates must have an opportunity to be placed on the ballot, ${ }^{661}$ the laws of fifteen jurisdictions - flatly prohibiting independents from running for the presidency (and affecting perhaps as many as 45,000 other elective offices at the federal, state and local level) - were forced to give way either voluntarily or by court order. ${ }^{662}$ Indeed, mainly through the efforts of supporters of Eugene McCarthy, "[i]n ten months in 1976 parts of the election laws of twenty-four states were altered or struck down." 663 Moreover, during the presidential election of 1980 , the independent candidacy of John Anderson resulted in successful federal court challenges to seven additional state requirements. 664

One may surely question the appraisal that these developments "may effect the most important change in the American body politic ever accomplished by court decisions." 665 But certain events - such as George Wallace's winning a place on the ballot in every state in 1968, James Buckley's election to the Senate as an independent in 1970, and James Longley's election as Governor of Maine as an independent in 1974 - point to their marked contribution to the revival of nonestablished candidacies and the enhancement of individual political rights. Their future potential for cracking the existing political structure is even more promising, especially in light of the increasing tendency of American voters (recently estimated as exceeding one-

658. See e.g., Socialist Labor Party v. Rhodes, 318 F. Suppp. 1262 (S.D. Ohio 1970), affd. sub nom. Sweetenham v. Gilligan, 409 U.S. 942 (1972); Socialist Workers Party v. Rockefeller, 314 F. Supp. 984 (S.D.N.Y.), affd., 400 U.S. 806 (1970); Socialist Workers Party v. Hare, 304 F. Supp. 534 (E.D. Mich. 1969).

659. 393 U.S. 23 (1968).

660. See American Party v. Jernigan, 424 F. Supp. 943 (E.D. Ark. 1977); Salera v. Tucker, 399 F. Supp. 1258 (E.D. Pa. 1975), affd., 424 U.S. 959 (1976); Toporek v. South Carolina Election Commn., 362 F. Supp. 613 (D.S.C. 1973); Barnhart v. Mandel, 311 F. Supp. 814 (D. Md. 1970).

661. 415 U.S. $724,745-46$ (1974).

662. See Armor \& Marcus, The Bloodless Revolution of 1976, 63 A.B.A. J. 1108.09 (1977).

663. Armor \& Marcus, supra note 662, at 1108.

664. See Anderson v. Celebrezze, 460 U.S. 780 (1983); Anderson v. Morris, 636 F.2d 55 (1980), vacated (on attorney fee issue), 658 F.2d 246 (4th Cir. 1981); Anderson v. Quinn, 634 F.2d 616 (1st Cir. 1980); Anderson v. Babb, 632 F.2d 300 (4th Cir. 1980); Anderson v. Poythress, 656 F.2d 702 (5th Cir. 1981); Anderson v. Hooper, 498 F. Supp. 898 (D.N.M. 1980) Anderson v. Mills, 497 F. Supp. 283 (E.D. Ky. 1980), revd. in part on other grounds, 664 F.2d 600 (6th Cir. 1981) (state law grounds); see also Greaves v. State Bd. of Elections, 508 F. Supp. 78 (E.D.N.C. 1980).

665. Armor \& Marcus, supra note 662, at 1108. 
third) ${ }^{666}$ to abjure major political party affiliation and identify themselves with individual candidates. ${ }^{667}$ Thus, in 1980, Congressman John Anderson obtained a ballot position in every jurisdiction in the nation, ${ }^{668}$ seriously threatened to determine the contest between Ronald Reagan and Jimmy Carter, ${ }^{669}$ probably cost the incumbent a substantial number of electoral votes, ${ }^{670}$ and actually received almost seven percent of the ballots cast. ${ }^{671}$

Moreover, scholars have shown that, throughout our history, "by voicing grievances and by proposing panaceas, third parties have exerted significant influence upon the policies and programs of major parties."672 Indeed, minor political groups initially proposed and worked for the adoption of a large number of fundamental precepts that eventually became part of the fabric of American institutions including national political party nominating conventions and platforms, women's suffrage, old age pensions, ${ }^{673}$ primaries for party nominations and the elections of delegates to national conventions, 674 the direct election of U.S. senators, ${ }^{675}$ the secret ballot, the graduated income tax, ${ }^{676}$ and taxation of rent income and mechanics lien laws. 677 Third parties have been instrumental in fueling the political movements that have led to the abolition of slavery ${ }^{678}$ and the establishment of free public education. ${ }^{679}$ The American Independent Party has been credited with focusing the nation's attention on the issue of busing in 1968, thus prodding the major parties to address the problem

666. See McClellan \& Anderson, The Bipartisan Ballot Monopoly, THE Progressive, Mar. 1975, at 18; Armor \& Marcus, supra note 662, at 1108.

667. See Note, Changes in Party Affiliation and the Right to Vote in the Primary, 51 N.C. L. REv. 543, 553 (1973).

668. See Reagan Buries Carter in a Landslide, 38 CoNG. Q. WKIY. REP. 3296, 3299 (1980) [hereinafter cited as Landslide]. Ed Clark of the Libertarian Party also obtained a ballot position in every jurisdiction. F. SMallwood, THE OTHER CANDIDATES 173 (1983).

669. Landslide, supra note 668, at 3296; 38 Cong. Q. WkLY. ReP. 3231 (1980). Political contests have been determined by independent candidates in the past. W. HESSELTINE, THIRD PARTY Movements IN THE United States 74 (1962) (Theodore Roosevelt's Bull Moose Progressive Party in the national election of 1912); id. at 19 (anti-Masonic party in many state elections in the 1830's).

670. Landslide, supra note 668 , at 3298.

671. Id. at 3299.

672. W. HESSELTINE, supra note 669 , at 3.

673. F. SMALLWOOD, supra note 668 , at 26.

674. W. HesseltiNe, supra note 669 , at 72.

675. D. Mazmanian, Third Parties in Presidential Elections 58 (1974).

676. W. HesSELTINe, supra note 669, at 61.

677. Id. at 23.

678. F. SMALLWOOD, supra note 668 , at 25 .

679. W. HASSELTINE, supra note 669, at 21. 
seriously. ${ }^{680}$ In addition, third parties have been said to fulfill the critical function in our two-party scheme of "[providing] access to the political arena" for frustrated minorities, and thus "enabling them to work legitimately within the confines of the American political system,"681 and stimulating major parties to be "more responsive to genuine public concerns." 682

Through the Justices' efforts since 1968, there is even greater reason to believe that splinter groups and independent candidates will continue to exert such strong influence on American political life, even if unsuccessful at the polls. Indeed, given that "a major portion of the responsibility" for the difficulties confronting third parties has been attributed by a host of political scientists to "the exclusionary effect of the legal techniques" 683 under discussion, the periodic success of minor party nominees for various state and federal offices in the past despite these obstacles, ${ }^{684}$ and the enormous number of positions (mentioned above) now opened to political outsiders by the federal judiciary, the prognoses for the Court's impact in this area may well turn out to be somewhat less extravagant than they seem to be.

\section{G. Discrimination Against New Residents}

In a series of decisions commencing in 1969, the Court rejected rules in every state by invalidating durational residency requirements for welfare benefits, voting, and medical care for indigents. Prior to Shapiro v. Thompson, ${ }^{685}$ which eliminated one-year waiting periods for welfare assistance, over eighty percent of the states imposed at least this long a requirement for Old Age Assistance, Aid to the Blind, Aid to Dependent Children, or Aid to the Permanently and Totally Disabled. 686

680. D. MAZMANIAN, supra note 675 , at 85-87.

681. F. SMALLwOOD, supra note 668 , at 25 .

682. Id. at 27.

683. Note, Legal Obstacles to Minority Party Success, 57 YALE L.J. 1276 (1948).

684. See Bell, Constraints on the Electoral Success of Minor Political Parties in the United States, 25 Pol. STudies 103, 108 (1977).

685. 394 U.S. 618 (1969).

686. See Note, Residence Requirements in State Public Welfare Statutes - I, 51 Iowa L. REv. 1080, 1091-95 (1966). Indeed, about three-fourths of the jurisdictions demanded that applicants "have resided within the state five of the preceding nine years, including the immediate past year to be eligible to receive old age, deaf and blind benefits." Thompson v. Shapiro, $270 \mathrm{~F}$. Supp. 331, 339 n.2 (D. Conn. 1967) (Clarie, J., dissenting).

Derived from the Elizabethan Poor Law, durational residence provisions "had been part of the states' poor relief laws from the beginning," Rosenheim, Shapiro v. Thompson: "The Beggars Are Coming to Town," 1969 SuP. CT. REv. 303, 304, despite abolition recommendations in the decade before Shapiro by the Governor's Conference, the HEW Advisory Council on Public Assistance, the White House Conference on Children and Youth, the White House Conference 
The extent to which waiting-period barriers have actually deterred poor people from exercising their constitutional right of interstate migration is uncertain, ${ }^{687}$ though by no means disproven. ${ }^{688}$ But it is clear that their elimination has markedly improved the lot of a great many indigents. Although the experience in some jurisdictions that removed durational requirements indicated that only a negligible number of additional persons received aid, ${ }^{689}$ statistics from others revealed more significant increases, ${ }^{690}$ thus confirming HEW's estimate in 1968 "that the elimination of residency requirements would nationally increase by 100,000 to 200,000 "691 the number of impoverished citizens able "to obtain the very means to subsist."692

As for durational residency requirements for voting, at the time of the Court's decisions in Dunn v. Blumstein ${ }^{693}$ and its direct progeny ${ }^{694}$ - invalidating any waiting period much beyond fifty days for registering to vote in state or local elections - all jurisdictions mandated a longer span for state elections (two-thirds stipulating a year or more) and more than half the states set a period of three to six months for county elections. ${ }^{695}$ It has been estimated

on Aging, the 1960 Democratic Party Platform and others. Brief for Appellant at 15-16, Memorial Hosp. v. Maricopa County, 415 U.S. 250 (1974).

687. See 394 U.S. at 650 (Warren, C.J., dissenting); Artigues, A Study of Residence Requirements and Reciprocal Agreement in the Public Assistance Program in Pennsylvania (1959) (unpublished dissertation), cited in Brief for Appellants, app., at 26 n.6, Reynolds v. Smith, 394 U.S. 618 (1969).

688. For example, the conclusion of a study by the D.C. Dept. of Public Welfare, that "figures relating to place of birth and migration of mothers and children support the belief that few if any families either white or Negro, move into the District for the purpose of obtaining public assistance," Problems of Hungry Children in the District of Columbia: Hearings Before the Subcomm. on Public Health, Education, Welfare, and Safety of the Senate Comm. on the District of Columbia, 85th Cong., 1st Sess. 523.(1957), ignores the fact that the D.C. waiting period provision may itself have seriously influenced these findings.

689. These states include Hawaii, Kentucky, Maine, Rhode Island, and South Carolina. See Brief for The Center on Social Welfare Policy and Law as Amicus Curiae at 28-29, Shapiro v. Thompson, 394 U.S. 618 (1969); Note, Shapiro v. Thompson: $A$ New Approach Under the Equal Protection Clause?, 6 CAL. W. L. REv. 179, 195 (1969).

690. See, e.g., Note, supra note 689, at 194-95 (California - 10\%, Illinois - 7.4\%); Rosenheim, supra note 686, at 328 n.106 (Washington, D.C. - 3-6\% for various categories); Kasius, What Happens in a State Without Residence Requirements, in RESIDENCE LAWS: ROAD BLOCK TO HUMAN Welfare 18, 19-20 (National Travelers Aid Association 1950) (New York - 2\%);

Brief for Appellees at 12 n.12, Shapiro v. Thompson, 394 U.S. 618 (1969) (Connecticut - 2\%).

691. Note, supra note 689, at 195.

692. Shapiro v. Thompson, 394 U.S. at 627 . In terms of actual dollars provided, Connecticut's $2 \%$ growth for ADC recipients alone was estimated to come to $\$ 2,000,000$ annually. Thompson v. Shapiro, 270 F. Supp. 331, 337 n.4 (D. Conn. 1967). California's outlay during the first two months of unrestricted benefits amounted to $\$ 385,000$. Note, supra note 689 , at 194 .

693. 405 U.S. 330 (1972).

694. Marston v. Lewis, 410 U.S. 679 (1973); Burns v. Fortson, 410 U.S. 686 (1973).

695. Note, Durational Residency Requirements in State Elections: Blumstein v. Ellington, 46 IND. L.J. 222, 223-24 n.10 (1971). 
that residency requirements disenfranchised five million citizens in 1954, between five and eight million in 1960, almost fifteen million in 1964, and another five to eight million in 1968. . . . Moreover the class of people who move are, "as a single gross category . . . men who tend to be somewhat better educated and who have considerably better jobs and higher incomes than the natives of the region they leave"; the class of people who are most likely to vote if given the opportunity. ${ }^{696}$

Specific election contests even more dramatically underline the potential consequences. As just one example, in 1970, when nearly 14,000 Indiana citizens "lost the right to vote from intrastate movement alone," 697 the U.S. Senate race "was decided by only 4,383 votes, while other state offices were won or lost by margins as low as 7,416 and 476." 698 By 1972, a comprehensive study reported that "relatively few people were still affected by residency requirements. Our estimates indicate that the probability of voting in the 1972 general election was not affected by existing residency requirements anywhere." 699

The Court's decision in Memorial Hospital v. Maricopa County 700 - holding violative of equal protection a requirement of one year's residence in the county for indigents to receive free nonemergency hospitalization or medical care - affected substantially fewer people. After 1960, the Social Security Act forbade states participating in the federal Medicaid program for the aged from imposing waiting periods as a condition for eligibility. ${ }^{701}$ But because many state medical care plans were independent of Medicaid, durational residency provisions persisted in nearly one-third of the states. ${ }^{702}$ Lower court rulings relying on Shapiro produced their demise in ten states and Memorial Hospital ended them in the remaining five. ${ }^{703}$ Figures from Maricopa County, Arizona alone estimate an annual increase of 20,000 in-patient hospitalization days and 17,500 out-patient clinic visits for indigent new residents. ${ }^{704}$ These statistics suggest the importance of the Justices' edict for people's health and lives, a matter powerfully confirmed by pre-Memorial Hospital denials of nonemergency treatment of Arizona indigents for such conditions as childbirth, epilepsy, diabe-

696. Id. at 224-25 (footnote omitted).

697. Id. at 225 .

698. Id. at 225 .

699. Rosenstone \& Wolfinger, The Effect of Registration Laws on Voter Turnout, 72 AM. Pol. SCI. REv. 22, 33-34 (1978).

700. 415 U.S. 250 (1974).

701. 42 U.S.C. $\S 1396 a(b)(2)-(3)$ (1982).

702. Brief for Appellant, supra note 686, at 51-54.

703. Id.

704. Id. at 34. 
tes and severe injuries in a fire. ${ }^{705}$

Although the Justices have made clear that not all waiting periods for the benefit of public privileges are forbidden, ${ }^{706}$ the effect of their invalidations has been extended significantly by the lower courts. State and federal judges have overwhelmingly rejected durational residence requirements for government employment and private employment on public projects. ${ }^{707}$ Federal courts of appeals that have addressed the issue have brought waiting periods for public housing within the principle's protective coverage. ${ }^{708}$ As for waiting periods for bar admission, which existed in a substantial number of the states, ${ }^{709}$ although the Supreme Court has summarily affirmed the constitutionality of a fairly short requirement, ${ }^{710}$ a host of lower federal courts have disapproved longer ones, ${ }^{711}$ thus seriously jeopardizing the myriad durational provisions for licensing of such other professions as medicine, dentistry, architecture and accounting. ${ }^{712} \mathrm{Fi}$ nally, despite several Supreme Court decisions summarily affirming waiting periods in order to be a candidate for state, county or municipal office ${ }^{713}$ - required almost universally and ranging up to ten years $^{714}$ - nearly two dozen state and federal courts have reached contrary results on the particular facts before them. ${ }^{715}$

705. Brief for Maricopa County Legal Aid Society as Amicus Curiae at 24, Memorial Hospital v. Maricopa County, 415 U.S. 250 (1974).

706. See Sosna v. Iowa, 419 U.S. 393 (1975); Vlandis v. Kline, 412 U.S. 441 (1973).

707. See cases cited in Note, Durational Residence Requirements for Public Employment, 67 CALIF. L. REV. 386, 388-89 n.15-18 (1979); Note, Durational Residence Requirements From Shapiro Through Sosna: The Right to Travel Takes a New Turn, 50 N.Y.U. L. REv. 622, 636-37 n.97 (1975) [hereinafter cited as Note, New Turn].

708. King v. New Rochelle Mun. Hous. Auth., 442 F.2d 646 (2d Cir.), cert. denied, 404 U.S 863 (1971); Cole v. Housing Auth. of Newport, 435 F.2d 807 (1st Cir. 1970).

709. See National. Conference of Bar Examiners, The Bar Examiners' Handbook 15 (1968).

710. Suffling v. Bondurant, 339 F. Supp. 257 (D.N.M.), affd. mem. sub nom. Rose v. Bondurant, 409 U.S. 1020 (1972) (six-months residency requirement upheld).

711. See cases cited in Note, The Constitutionality of State Residency Requirements for Admission to the Bar, 71 Micr. L. REV. 838, 839 n.7 (1973); Note, New Turn, supra note 707, at 645 n.144.

712. See, e.g., Mercer v. Hemmings, 194 So. 2d 579 (Fla. 1966) (striking down portion of Florida statute requiring two-year residency by accountants).

713. Sununu v. Stark, 420 U.S. 958 (1975), affg. mem. 383 F. Supp. 1287 (D.N.H. 1974) (three-judge court); Kanapaux v. Ellisor, 419 U.S. 891 , affg. mem. Civil No. 74-1356 (D.S.C. Nov. 3, 1974) (three-judge court); Chimento v. Stark, 414 U.S. 802, affg. mem. 353 F. Supp. 1211 (D.N.H. 1973) (three-judge court); Hadiott v. Amos, 401 U.S. 968 (1971), affg. mem. 320 F. Supp. 107 (M.D. Ala. 1970) (three-judge court).

714. See Le Clercq, Durational Residency Requirements for Public Office, 27 S.C. L. REv. 847 n.1 (1976).

715. See cases cited in Le Clercq, supra note 714, at 848-49; see also, eg., Henderson v. Fort Worth Indep. School Dist., 526 F.2d 286 (5th Cir. 1976) (striking three-year "qualified voter" requirement for school board position); Billington v. Hayduk, 439 F. Supp. 975 (S.D.N.Y.), affd., 565 F.2d 824 (1977) (striking five-year residency requirement for position of county executive). 


\section{H. Debtors' Rights: Wage Garnishment}

Prior to the Court's 1969 decision in Sniadach v. Family Finance Corp., ${ }^{716}$ nearly twenty states ${ }^{717}$ permitted a creditor, even in the absence of extraordinary circumstances, to obtain a prejudgment garnishment of a person's wages without any prior notice to the alleged debtor or opportunity for a hearing at which the debtor might defend against the plaintiff's claim. Although there are no nationwide statistics on the actual number of persons who were subject to this procedure, the fact that there were 78,000 wage garnishments in Chicago alone in $1969^{718}$ and over 20,000 prejudgment wage garnishments in Wisconsin's five most populous counties in $1968^{719}$ suggests the magnitude of the problem.

Loss of employment by the debtor has been the most direct adverse consequence of wage garnishment. ${ }^{720}$ Because of the substantial administrative expense imposed on the employer ${ }^{221}$ and the belief that garnishment is evidence of poor character, ${ }^{722}$ it was estimated in 1967 that between 100,000 and 300,000 American workers were being fired annually because of garnishment. ${ }^{723}$ As would be expected, unskilled laborers, low income persons and members of racial minorities were heavily overrepresented in this group. ${ }^{724}$ A 1964 survey showed that

716. 395 U.S. 337 (1969).

717. See Report of the NATL. Advisory Commn. ON Civil Disorders 140 (1968); Petitioner's Brief for Certiorari at 7, Sniadach v. Family Fin. Corp., 395 U.S. 337 (1969).

718. D. Caplovitz, Consumers in Trouble 2 (1974).

719. Brief of Petitioner at 10, Sniadach v. Family Fin. Corp., 395 U.S. 337 (1969).

720. Some of the data referred to below concemed postjudgment garnishment as a form of execution and thus may not be automatically transposable to the prejudgment garnishment at issue in Sniadach.

721. Several studies estimated the cost at $\$ 15$ to $\$ 35$ per garnishment. D. CAPLoviTz, supro note 718, at 237 n.10; WESTERN CENTER ON LAW \& POVERTY, WAGE GARNISHMENT - IMPaCt AND EXTENT IN Los ANGeles CounTy 5 (1968); Consumer Credit Protection Act: Hearings on H.R. 11601 Before the Subcomm. on Consumer Affairs of the House Comm. on Banking and Currency, 90th Cong., 1st Sess. 766 (1967) (statement of James Gannon, Staff Reporter of the Wall Street Journal) [hereinafter cited as Consumers Credit Hearings]. Boeing Corporation in Seattle alone reported an annual cost of over $\$ 20,000$. Project, Wage Garnishment in Washington - An Empirical Study, 43 WASH. L. REV. 743, 755-56 (1968).

722. See Western CENTER ON LAW \& POVERTY, supra note 721, at 48; Comment, supra note 721 , at 756 n.78.

723. Consumers Credit Hearings, supra note 721, at 739.

724. See D. CAplovitz, supra note 718, at 233-43; Western CENTER on LAW AND PovERTY, supra note 721, at 5, 9; Ryan \& Maynes, The Excessively Indebted: Who and Why, 3 J. CONSUMERS AFF. 107, 112 (1969). More recent legislation, however, exempting certain amounts of wages from being gamished, has significantly reduced the impact of wage garnishment on low income debtors. See 15 U.S.C. $\$ 1673$ (1982) (exempting $75 \%$ or 30 times the minimum wage, whichever is lower); WIS. STAT. $\$ 425.106$ (1977) (exempting 75\% or 40 times minimum wage). For evidence of other potential impacts see generally, Whitford, $A$ Critique of the Consumer Credit Collecting System, 1979 WIS. L. REv. 1047, 1135 (suggesting limiting debtor remedies will lead to drop in availibility of credit). 
thirteen percent of American manufacturing firms fired workers as soon as their wages were garnished. ${ }^{725}$ Statistics from various areas throughout the country confirm this phenomenon. ${ }^{726}$ Although the Consumer Protection Act of 1968 forbids employee discharge for a single garnishment ${ }^{727}$ its ameliorating effect appears to have been minimal at best. ${ }^{728}$ Consequently, debtors whose salaries were garnished or so threatened, much more often than nongarnished debtors, settled on terms they believed to be unfair in order to avoid the loss of employment that would occur before they had any opportunity to test the defense. 729 "The result in many cases [was] vicious, allowing "loan sharks and collection agencies practically to blackmail a debtor by tying up his wages in advance of proving the validity of their claim, and without prior notice of intent to attach." "730

The modest ruling in Sniadach, which left the state's power intact to authorize prejudgment wage garnishments and requires only prior

725. National Industrial Conference Board, Personnel Policy Study No. 194, Personnel Practices in Factory and Office: Manufacturing 38 (table 40) (1964).

726. In a detailed inverview-study of debtors in Chicago, Detroit and New York, it was found that "[n]ot only did 19 percent of the garnisheed lose their jobs by the time of the interview, but fully 43 percent of the garnisheed had either lost their jobs or were threatened with job loss by their employer." D. CAPLOVITZ, supra note 718, at 275-76. In Seattle, $19 \%$ of employers surveyed reported that they "always" discharged an employee for wage garnishment and $54 \%$ said that they "sometimes" did so. Project, supra note 721, at 757 n.79. A similar survey in San Diego disclosed that $17 \%$ of the employers fired their workers after the second garnishment and $49 \%$ after the third. Consumers Credit Hearings, supra note 721, at 1020-21. A Wisconsin study revealed that $11 \%$ of garnished workers were fired immediately and $41 \%$ received a warning. Note, Wage Garnishment as a Collection Device, 1967 WIS. L. REV. 759, 766 n.29. Further evidence indicates that some workers simply quit their jobs because of fear of garnishment. D. CAPLoviTz, supra note 718, at 62. As a result, data from numerous informed sources shows a strong relationship between strict state wage garnishment laws and the number of personal bankruptcies. See authorities cited in Comment, Wage Garnishment: Still Driving the Wage-Earning Family to the Wall, 17 SANTA Clara L. Rev. 631, 653 (1977); Project, supra note 721, at 76667. But see D. CAPLovitz, supra note 718, at 274-75; Brunn, Wage Garnishment in California: A Study and Recommendations, 53 CALIF. L. REV. 1214, 1236 n.122 (1965).

It has been reported that the threatened use by consumer debtors of Chapter 13 of the Bankruptcy Reform Act of 1979,11 U.S.C. $\$ 362$, - which greatly eases the way for them to discharge their obligations - has acted as a significant disincentive to creditors to institute wage garnishments and made them much more amenable to less drastic accommodations. See, e.g., Aaron, The Bankruptcy Reform Act of 1978: The Full Employment for Lawyers Bill (part IV) 1982 UTAH L. REV. 237 (discussing the effect of the more generous chapter 13 provisions on creditor-debtor relations).

727. 15 U.S.C. § 1674 (1982).

728. "Dismissal occurs because in many states the same debt may involve multiple garnishments, to say nothing of multiple garnishments for different debts, and because it is very difficult to prove that the dismissal stemmed from the garnishment order rather than some other cause." D. CAPLovitz, supra note 718, at 238. Indeed, it has been observed that wage garnishment "is detested as an unmitigated nuisance by employers to such an extent that even union contracts tacitly or specifically recognize the right of an employer to discharge an employee whose debts result in more than a prescribed number of garnishments within a specified period." Note, Garnishment in Kentucky - Some Defects, 45 KY. L.J. 322, 330 (1956-57).

729. See D. CaPlovitz, supra note 718 , at 244-45.

730. Note, supra note 728 , at 327-28. 
notice to the debtor and an opportunity to be heard, obviously has not eliminated all of these hardships. But it does address some important elements of the problem. Although the evidence is fragmentary and often based more on self-serving opinion than hard fact, it suggests that in a significant number of garnishment cases the underlying debt may be subject to a valid defense - such as that payment has been made or "complaints about defective merchandise, wrong merchandise, price and insurance deception, . . . [and] being tricked into signing contracts."731 Sniadach assures the debtor the chance of effectively presenting his defense and thereby preventing the garnishment altogether. Even if the debtor declines to avail himself of the opportunity of a hearing - as studies indicate is true of the large majority of those who have been sued for the debt ${ }^{732}$ - and reaches an accord with the creditor that the debtor feels is unjust, at least his adversity will not be compounded by his having lost his job as well.

\section{Expatriation}

Prior to the series of Warren Court decisions culminating in its 1967 ruling in Afroyim v. Rusk, ${ }^{733}$ an immense number of American citizens were expatriated because they engaged in conduct for which acts of Congress withdrew their citizenship. The first case in the Court's progression that culminated in Afroyim was Trop v. Dulles, ${ }^{734}$ which invalidated a federal law authorizing expatriation of members of the armed services who deserted in wartime. Although the statute originated in the Civil War, statistics on the number of military personnel disabled under it during the Spanish-American War and World War I do not appear to be available. The Court noted, however, that

[d]uring World War II, according to Army estimates, approximately 21,000 soldiers and airmen were convicted of desertion and given dishonorable discharges by the sentencing courts-martial and that about 7,000 of these were actually separated from the service and thus rendered stateless when the reviewing authorities refused to remit their dishonorable discharges. ${ }^{735}$

This figure must be augmented by those in the Navy and Marines who were treated correspondingly. During the Korean War, although nearly 3,400 members of the army alone were convicted for deser-

731. D. CAPLovitz, supra note 718, at 91 . See also id. at 37-41, 91-130; 118 CoNG. REC. 1831-32 (1968).

732. See D. Caplovitz, supra note 718 , at 215-22.

733. 387 U.S. 253 (1967).

734. 356 U.S. 86 (1958).

735. 356 U.S. at 91. 
tion, ${ }^{736}$ apparently no more than eleven actually lost their nationality. ${ }^{737}$ The Vietnam era, of course, came after Trop. The fact that almost 1,000 soldiers were convicted of desertion between 1964 and $1971,{ }^{738}$ and that more than 10,000 additional military personnel were fugitive AWOL offenders as of 1974,739 suggests the wide scope of protection that Trop has afforded to personal liberties.

The Court's edict in Kennedy v. Mendoza-Martinez, ${ }^{740}$ that Congress could not revoke the citizenship of persons who flee the country to avoid military service, similarly preserved the individual rights of countless numbers of Americans. Again, the sanction was originally enacted during the Civil War and again, comprehensive statistics appear to be unavailable. But the fact that as of 1944

the Department of Justice discovered that in the western district of Texas, in the vicinity of El Paso alone, there were over 800 draft delinquents . . . who had crossed the border into Mexico for the purpose of evading the draft, but with the expectation of returning to the United States to resume residency after the war ${ }^{741}$

strongly implies that many tens of thousands of persons fell within the statute's potential proscription. More precise figures disclose that approximately 2,000 draft evaders were administratively deemed to be expatriated pursuant to this law between the end of World War II and the statute's demise in 1963.742 Were it not for Mendoza-Martinez, many more who left the United States to avoid military duty during the war in Vietnam might also be added to the list - a recent estimate revealed that about 5,000 such young men took exile in Canada for this period. ${ }^{743}$

Further, the Court's holding in Schneider v. Rusk ${ }^{744}$ in 1964, condemning a statute that denationalized any naturalized American who lived continuously for three years in the country to which he formerly owed allegiance, spared the citizenship of a suprisingly large number of people. The law had been in effect since 1940. Immigration Service statistics showed that nearly 14,000 naturalized citizens had been ex-

736. See L. Baskir \& W. Strauss, Reconciliation AfTer VietNam 128 (1977).

737. See Note, The Expatriation Act of 1954, 64 YALE L.J. 1164, 1165 n.9 (1955).

738. See L. BASKIR \& W. STRAuss, supra note 736, at 128.

739. Presidential Clemency Board, Report to the President xiii (1975).

740. 372 U.S. 144 (1963).

741. H. R. REP. No. 1229, 78th Cong., 2d Sess. 2 (1944).

742. See Note, supra note 737, at 1165 n.9 (1,281 persons between 1945 and 1953); Brief for Appellant at 51 n.29, Kennedy v. Mendoza-Martinez, 372 U.S. 144 (1963) (883 persons between 1948 and 1956); INS ANN. REP. 109 n.1 (table 51) (1964) (359 persons from 1955 to 1963) [hereinafter cited as 1964 INS REP.].

743. See L. BASKIR \& W. STRAUSS, supra note 736, at 137.

744. 377 U.S. 163 (1964). 
patriated under this statute in the last ten years of its operation,745 data for the first fourteen years of its tenure not being readily available.

The particular congressional act held invalid in Afroyim v. Rusk provided for loss of citizenship by any person who voted in a foreign political election. This statute too had resulted in statelessness for about 14,000 Americans between 1955 and 1968 alone, ${ }^{746}$ figures for the earlier fourteen years of its effectiveness not being published. But the impact of $A$ froyim's rationale was much broader. It reasoned that American citizenship attained by either a person's being born or naturalized in the United States cannot be lost except "by the voluntary renunciation or abandonment by the citizen himself." 747 Although a few people continue to be administratively stripped of their citizenship in seeming conflict with Afroyim's doctrine, ${ }^{748}$ the fact is that the Court's mandate has almost wholly circumscribed Congess' power of expatriation, thus securing this fundamental right from potentially innumerable future abridgments.

\section{The Burger Court}

It is often heard that judicial protection of personal liberties, which concededly blossomed under Earl Warren, withered rapidly in 1969 with the seating of his successor and died completely by 1972 when all four of President Nixon's appointees had been finally confirmed. However, although there is no denying that, overall, the Burger Court has been less sympathetic to claims of infringement of individual rights than was its predecessor - after all, no Supreme Court in our history has been as protective of personal freedom as the Warren Court - examination of the record discloses that the Court's decisions since 1969 have had a very significant impact on the lives and liberties of individuals. ${ }^{749}$

745. 1964 INS REP., supra note 742, at 109 (table 51).

746. 1964 INS REP., supra note 742, at 109 (11,945 persons from 1955 to 1964); INS ANN. REP. 121 (1967) (869 persons in 1965); INS ANN. REP. 135 (1975) (1,159 persons from 1966 to 1968) [hereinafter cited as 1975 INS REP.].

747. 387 U.S. at 266. Cf. Rogers v. Bellei, 401 U.S. 815 (1971) (doctrine inapplicable to citizenship attained other than by being born or natucalized in the United States).

748. See, e.g., 1975 INS REP., supra note 746, at 135 ( 99 persons expatriated between 1970 and 1975 for serving in the armed forces of a foreign state).

749. See generally Choper, supra note 27, at 785-87; Burger-Led Court Surprises Experts, N.Y. Times, Jan. 6, 1980, at 25, col. 1. 


\section{A. Rights of the Accused}

\section{Search and Seizure}

a. Persons present during lawful search. In 1979, in Ybarra v. Illinois, 750 the Court held that when the police have a warrant to search designated premises or persons, they cannot (a) conduct a search of persons present (but unnamed in the warrant) for evidence without probable cause, nor (b) make a patdown search of such persons for weapons unless there is a reasonable belief or suspicion that they are armed and presently dangerous. At the time of the Court's decision, the Public Defender of California contended that "[a] clear majority of jurisdictions which have considered the question"751 agreed with the Court's conclusion, whereas another commentator found the Court's approach to be "the minority position"752 - "[t] great majority of cases preceding Ybarra upheld the use of evidence ... [taken pursuant to a warrantless search of] persons present at a lawful search of the premises." 753

A number of factors have tended to account for the difficulty of determining just how many state rules were modified - and in exactly what ways - by the Justices' pronouncement. Although research discloses that the courts of approximately thirty jurisdictions had addressed various aspects of the problem 754 - and about fifteen states (in some of which there were also court decisions) had statutes authorizing the search of persons present during execution of a search warrant for the purposes of protecting the police or preventing destruction of items described in the warrant ${ }^{755}$ - decisions in both statutory and nonstatutory jurisdictions that permitted evidentiary searches on less than probable cause often drew distinctions based on the nature of the premises for which the warrant was issued. About a half dozen states 756 in addition to Illinois appeared to allow a "blanket search" of

750. 444 U.S. 85 (1979).

751. Brief for State Public Defender of California as Amicus Curiae at 25, Ybarra v. Illinois, 444 U.S. 85 (1979).

752. Supreme Court Review, Fourth Amendment - Search of an Individual Pursuant to a Warrant to Search the Premises, 71 J. CRIM. L. \& CRIMINologY 558, 561 (1980).

753. Id. at 562.

754. See notes 756-59 infra. For some speculative reasons as to why there were no reported decisions in many states despite the potentially widespread occurrence of the situation, see Note, 58 CORNELl L. Rev. 614, 614 n.4 (1973).

755. See Comment, Fourth Amendment Rights of Persons Present when a Search Warrant is Executed: Ybarra v. Illinois, 66 IowA L. REv. 453, 455 n.22 (1981); Note, Criminal Law Search of a Person Present on Premises Subject to a Search Warrant - Ybarra v. Illinois, 28 KaN. L. Rev. 512, 513 n.10 (1980).

756. See Colding v. State, 259 Ark. 634, 536 S.W.2d 106 (1976); Samuel v. State, 222 So. 2d 3 (Fla. 1969); State v. Loudermilk, 208 Kan. 893, 494 P.2d 1174 (1972); Commonwealth v. 
all persons on the premises unless the circumstances indicated that they were "innocent stranger(s) having no connection with the premises" such as a crowd of patrons at a "large retail or commercial establishment."757 Four other states seemed only to authorize a full search for evidence of persons present but unmentioned in the warrant if the place to be searched was a residence or automobile rather than a "public" area. ${ }^{758}$ On the other hand, it appears that nearly two-thirds of the states with an articulated view on the question had already adopted (or had come very close to) the probable cause standard mandated by the Court. ${ }^{759}$ Thus, overall, it is fair to say that Ybarra probably expanded the privacy rights of those at the scene of a search warrant's implementation ${ }^{760}$ in more than one-third of the country.

The qualitative value of the Court's decree is quite obvious. Although it is undoubtedly true that a contrary rule - permitting all persons present to be subjected to a complete search - would markedly enhance the detection of crimes and the seizure of evidence and contraband, ${ }^{761}$ a study of sixty cases taken from the files of the Chicago Police Department to document this fact also plainly reveals the degree to which it compromises the personal liberties of innocent people. ${ }^{762}$

Smith, 348 N.E.2d 101 (Mass.), cert. denied, 429 U.S. 944 (1976); Brown v. State, 498 S.W.2d 343 (Tex. Crim. App. 1973); United States v. Graves, 315 A.2d 559 (D.C. 1974).

757. People v. Ybarra, 58 Ill. App. 3d 57, 61-62, 373 N.E.2d 1013, 1016 (1978), revd., 444 U.S. 85 (1979) (emphasis added).

758. See State v. Cochran, 135 Ga. App. 47, 217 S.E.2d 181 (1975); Willis v. State, $122 \mathrm{Ga}$. App. 455, 177 S.E.2d 487 (1970); State v. Sims, 75 N.J. 337, 382 A.2d 638 (1978); People v. Nieves, 36 N.Y.2d 396, 369 N.Y.S.2d 50, 330 N.E.2d 26 (1975); People v. Nicoletti, 60 Misc. 2d 108, 302 N.Y.S.2d 618 (1969); Van Horn v. State, 496 P.2d 121 (Okla. Crim. App. 1972).

759. See Smith v. State, 292 Ala. 120, 289 So. 2d 816 (1974); State v. Mendez, 115 Ariz. 367, 565 P.2d 873 (1977); People v. Valdez, 260 Cal. App. 2d 895, 67 Cal. Rptr. 585 (1968); People v. Lujan, 174 Colo. 554, 484 P.2d 1238 (1971); State v. Procce, 5 Conn. Cir. Ct. 637, 260 A.2d 413 (1969); State v. Wise, 284 A.2d 292 (Del. Super. Ct. 1971); State v. Nabarro, 55 Hawaii 585, 525 P.2d 573 (1974); Purkey v. Maby, 33 Idaho 281, 193 P. 79 (1920); McAllister v. State, 159 Ind. App. 340, 306 N.E.2d 395 (1974); State v. Burns, 306 A.2d 8 (Me. 1973); Sibiski v. State, 19 Md. App. 149, 310 A.2d 200 (1973); State v. Fox, 283 Minn. 176, 168 N.W.2d 260 (1969); State v. Bradbury, 109 N.H. 105, 243 A.2d 302 (1968); Commonwealth v. Platou, 455 Pa. 258, 312 A.2d 29 (1973), cert. denied, 417 U.S. 976 (1974); State v. Carufel, 106 R.I. 739, 263 A.2d 686 (1970); Tacoma v. Mundell, 6 Wash. App. 673, 495 P.2d 682 (1972); State v. Massie, 95 W. Va. 233, 120 S.E. 514 (1923); State v. Wuest, 190 Wis. 251, 308 N.W. 899 (1926).

760. For discussion of the clarity of Ybarra's application to warrant authorized searches of "private premises," see 2 W. LAFAVE, SEARCH AND SEIzURE: A TREATISE ON THE FouRTH AMENDMENT $\$ 4.9$ (Supp. 1984).

761. See Brief for Americans for Effective Law Enforcement, Inc. et al. as Amici Curiae at 2 14, Ybarra v. Illinois, 444 U.S. 85 (1979).

762. In an example that typifies many of those offered, during the execution of a warrant to search an apartment for narcotics, an evidentiary search was made of all nine persons present although there was no reason to believe that any was guilty of an offense; while this resulted in the arrest of four individuals for possession of drugs or weapons, nothing incriminating was found on the other five. Id. at 12 (X708253); see also id. at 12-13 (P726675, A703426, Y701990). 
Several unanswered questions will ultimately determine just how important a protection of individual rights Ybarra actually affords. If the police need only satisfy a very lenient standard before making a patdown of all persons at the scene of a search warrant's implementation, and if the officers may then seize (and introduce against the defendant at trial) all evidence discovered pursuant to their exploration during the patdown, then the Justices' holding may well have at best a quite modest impact. ${ }^{763}$ But, as to the former issue, the Court's continued emphasis in the Ybarra opinion on the "narrow scope"764 of the patdown exception to the probable cause requirement strongly suggests that it will be vigilant in demanding "reasonable belief or suspicion directed at the person to be frisked, even though that person happens to be on premises where an authorized ... search is taking place."765 And, although the Court has yet to rule specifically on the latter issue, its position that the purpose of the patdown is (a) "to find weapons,"766 and (b) should not "be understood to allow ... any search whatever for anything but weapons" 767 at least implies that the seizure of most nonweapons evidence in this context will likely be held inadmissible. ${ }^{768}$

b. Arrest at suspect's home. The potentially far-reaching significance of the Court's 1980 decision in Payton v. New York ${ }^{769}$ - holding that, in the absence of exigent circumstances, the fourth and fourteenth amendments require the police to obtain a warrant before making a nonconsensual entry into a suspect's home in order to make an arrest ${ }^{770}$ - is evident from the fact that, at the time the decision was handed down, twenty-four states had expressly permitted such warrantless entries and only fifteen states unequivocally prohibited them. ${ }^{771}$ But Payton's ultimate value in securing personal liberty turns

This pattern is replicated by sundry data involving, for example, law enforcement officials emptying the purse of an attorney on the premises when her firm's files were being searched for client records, Los Angeles Times, Apr. 13, 1979, § 2, at 1, col. 4, and making a full search of a person who was simply standing at the curb in front of a house for which the police had a warrant. State v. McClelland, 215 Kan. 81, 523 P.2d 357 (1974).

763. See Comment, supra note 755 , at 464 .

764. 444 U.S. at 93.

765. 444 U.S. at 94.

766. 444 U.S. at 93.

767. 444 U.S. at $93-94$.

768. See generally Amsterdam, supra note 149, at 437-38; LaFave, "Street Encounters" and the Constitution: Terry, Sibron, Peters, and Beyond, 67 MICH. L. REv, 39, $91-93$ (1968).

769. 445 U.S 573 (1980).

770. In Steagald v. United States, 451 U.S. 204 (1981), the Court extended the principle to require a search warrant before police enter the home of a third party in order to seize a person for whom they have an arrest warrant.

771. 445 U.S. at 598-99. 
on the extent to which the Justices' ruling - which interposes the determination of a "neutral and detached magistrate"772 on the issue of probable cause "between the zealous officer and the citizen"773 will actually prevent unjustified invasions of privacy.

It is generally agreed that persons who are arrested or searched without probable cause presently have no reliable remedy for the unlawful intrusion. ${ }^{774}$ If incriminating evidence is acquired incident to the illegal arrest or search, the exclusionary rule may preclude its use against the defendant. Although this would afford the victim of the invalid arrest or search an enormous benefit, it would not directly repair the injury to his constitutional rights. If no evidence is seized pursuant to the unlawful arrest or search, the exclusionary rule is of no aid whatever. If there is adequate reason to believe that the arrested defendant is guilty he must stand trial regardless of the illegality of this seizure. ${ }^{775}$ And the exclusionary rule surely provides no solace for the wholly innocent victim of the police misconduct. Thus, the most effective way to deal with the harsh consequences of illegal arrests or searches is to stop them from occurring in the first place.

Although the Justices have often expounded the virtues of a warrant procedure in protecting against unconstitutional arrests and searches, it is unquestionably true that a wide gulf exists between the judicially stated ideal and actual practice. Various empirical studies have demonstrated that, notwithstanding the Court's talk about informed and deliberate determinations by impartial judicial officers, ${ }^{776}$ "the ex parte warrant procedure . . . is conducted in most jurisdictions by the lowest official in the judicial hierarchy"777 - usually magistrates (and occasionally court clerks ${ }^{778}$ ) who have often been nonlawyers" 779 - and that, in any event, "there is virtually no judicial

772. 445 U.S. at 586 n.24 (quoting Johnson v. United States, 333 U.S. 10, 14 (1948)).

773. 445 U.S. at 602.

774. See Bivens v. Six Unknown Named Agents of Federal Bureau of Narcotics, 403 U.S. 388, 411 (1971) (Harlan, J., concurring); Amsterdam, supra note 149, at 360-61; Newman, supra note 155 .

775. See United States v. Crews, 445 U.S 463 (1980).

776. See, e.g., United States v. Jeffers, 342 U.S. 48, 51 (1951); Aguilar v. Texas, 378 U.S. 108, 110 (1964).

777. Grano, A Dilemma for Defense Counsel: Spinelli-Harris Search Warrants and the Possibility of Police Perjury, 1971 U. ILL. L. F. 405, 415.

778. Shadwick v. City of Tampa, 407 U.S. 345 (1972). See generally Note, A Survey of the Qualifications of Magistrates Authorized to Issue Warrants, 9 VAL. U. L. REv. 443, 451-52 (1975).

779. Miller \& Tiffany, Prosecutor Dominance of the Warrant Decision: A Study in Current Practices, 1964 WASH. U. L.Q. 1, 12. But see Note, supra note 778, at 446-47 (federal magistrates must now be lawyers unless no lawyer is available), 453-55 (some states limit issuance of warrants to judges or lawyer-magistrates). 
inquiry into the existence of probable cause for the issuance of arrest warrants."780 Indeed, despite the Court's holding that a prosecutor's judgment that a warrant should issue does not satisfy the "impartial judicial officer" standard, ${ }^{781}$ a series of observational studies of actual practices have disclosed that, in fact, "the prosecutor plays a dominant role"782 and often "alone makes the effective warrant decision."783

But even apart from the warrant procedure's symbolic value or the possibility that the Court may in the future monitor the system more rigorously, there are several factors that indicate that Payton's requirement of a warrant will help secure individual rights. At a minimum, it should deter geographic dragnet searches for a fugitive or entries into the homes of all his acquaintances. ${ }^{784}$ Further, the warrant requirement demands that arresting officers prepare a written record prior to entry or seizure ${ }^{785}-$ a corrective for indolence leading to improper invasions of privacy and a protection against hindsight evaluations of probable cause. Moreover, "[a]lthough often influenced by the attitude of the police officer requesting the warrant, the prosecutor usually does give careful attention to the facts of the individual case and does in fact decide whether an arrest or prosecution is permissible and desirable." 786 Finally, despite the widespread belief that the protective features of the warrant requirement are seriously undermined by police perjury 787 (as well as by the rule that the identity of unnamed police informants need not be divulged ${ }^{788}$ ), the Court's decision in Franks v. Delaware ${ }^{789}$ - facilitating defendants' challenges to warrant

780. Miller \& Tiffany, supra note 779, at 6 .

781. Coolidge v. New Hampshire, 403 U.S. 443 (1971).

782. W. LAFAVE, supra note 156, at 34. See generally LaFave \& Remington, Controlling the Police: The Judge's Role in Making and Reviewing Law Enforcement Decisions, 63 MicH. L. REV. 987, 991-95 (1965).

783. Miller \& Tiffany, supra note 779 , at 4.

784. See Lankford v. Gelston, 364 F.2d 197 (4th Cir. 1966).

785. U.S. CoNST., amend. IV.

786. W. LAFAVE, supra note 156 , at 34. But see Grano, supra note 777 , at 414 . While "detailed consideration of the available evidence . . . is not customary," it does occur occasionally. See Miller \& Tiffany, supra note 779, at 13. Witnesses, the suspect, or the victim are sometimes interviewed and, in some instances, "reports of medical examiners, results of polygraph tests and physical evidence either of the crime or the condition of the victim are examined. And occasionally, defense attorneys are permitted to present arguments about the sufficiency of the evidence and even to call the attention of the prosecutor to additional evidence." Id. at 13-14. In Detroit, "[a] quite highly regularized system of intra-office review was established" to "insure uniformity in charging, both in its evidence sufficiency and policy aspects." Id. at 14. While these considerations and procedures provide added protection against misconduct as to arrest warrants, their effect on search warrants is likely to be substantially less.

787. See Sevilla, The Exclusionary Rule and Police Perjury, 11 SAN Diego L. Rev. 839, 86373 (1974) and authorities cited therein.

788. McCray v. Illinois, 386 U.S. 300 (1967).

789. 438 U.S. 154 (1978). 
affidavits - promises to ameliorate this condition by deterring such misconduct.

\section{Equality for the Poor}

a. Right to counsel. i. Preliminary hearings. Prior to the Court's 1970 decision in Coleman v. Alabama, ${ }^{790}$ although computations varied somewhat, it appeared that no more than one-third of the states appointed counsel for indigent criminal defendants at a preliminary hearing to test the sufficiency of the state's evidence to warrant holding the accused for prosecution. ${ }^{791}$ The absence of a lawyer was a significant reason for the very high percentage of waivers of preliminary hearings in several of those jurisdictions where counsel was not provided as compared to those states where it was. ${ }^{792}$

The potential assistance to the accused, as a result of Coleman, of competent representation at a preliminary hearing is substantial. The greatest benefit is the possibility that a "lawyer's skilled examination and cross-examination of witnesses may expose fatal weaknesses in the State's case"793 and thereby lead to dismissal. Various studies attest to the significance of this opportunity. Although "fruitful evaluation of their conclusions is made especially difficult . . . by substantial variations in the structure of the preliminary hearing as it is conducted throughout the country," 794 statistics indicate that the dismissal rate exceeds thirty percent in some major urban counties. ${ }^{795}$

It is true that, as a formal matter, a dismissal or reduction of charges at the preliminary hearing ordinarily "does not preclude the prosecutor from either taking the . . . case to the grand jury or, where prosecution is by information and a preliminary exam bindover is statutorily required, refiling the charges and seeking assignment of the

790. 399 U.S. 1 (1970).

791. See 1 L. Silverstein, Defense of the Poor in Criminal Cases in American State CourTs 75 (1965); Note, Constitutional Right to Counsel at the Preliminary Hearing, 75 Dick. L. ReV. 143, 145 (1970); see also 45 Tul. L. Rev. 1056, 1057-58 (1971). In federal prosecutions, the right was already provided by statute, 18 U.S.C. $\$ 3006 \mathrm{~A}(\mathrm{c})(1982)$, and by FED. R. CRIM. P. 44.

792. See Graham \& Letwin, The Preliminary Hearing in Los Angeles: Some Field Findings and Legal-Policy Observations, 18 UCLA L. REv. 635, 646-47, n.35 (1971).

793. Coleman, 399 U.S. at 9.

794. Y. Kamisar, W. LaFave \& J. IsRael, Modern Criminal Procedure: CasesCOMMENTS-QUESTIONS 963 (5th ed. 1980) [hereinafter cited as KAMISAR - 5th ed.].

795. Id., at 964; see also authorities cited $i d$. at 963 n. $a$. In addition, "a significant percentage of cases may be reduced to misdemeanors at the preliminary hearing stage, so that the percentage of cases 'boundover' for felony trials may be less than $30 \%$ of all the cases in which felony charges were originally filed." Y. KAMISAR, W. LAFAVE \& J. ISRAEL, MODERN CRIMINAL Procedure: CASES-Comments-Questions $958 \mathrm{n}$. $b$ (4th ed. 1974) [hereinafter cited as KAMISAR - 4th ed.]. 
preliminary hearing to another magistrate."796 But, as a practical matter, the prosecution will take such action "only in 'special' cases usually where additional evidence is obtained or the magistrate's ruling is considered clearly erroneous."797 Moreover, although "the grand jury is in no way limited by the bindover, and may refuse to indict despite the bindover, or may indict for a lesser or higher offense, depending upon the evidence presented to it," in most "information jurisdictions," the prosecutor is limited either "to the charges designated in the bindover decision" or to an offense disclosed by the evidence presented at the preliminary hearing. ${ }^{798}$ Thus, the aid of counsel at a preliminary hearing can have far-reaching consequences for the accused.

Apart from the chance of reduction of charges or outright dismissal, even if the defendant is bound over, "the skilled interrogation of witnesses by an experienced lawyer can fashion a vital impeachment tool for use in cross-examination of the State's witnesses at the trial, or preserve testimony favorable to the accused of a witness who does not appear at the trial." Moreover, "trained counsel can more effectively discover the case the State has against his client and make possible the preparation of a proper defense to meet that case at the trial" 799 - an especially valuable device where "state law and practice provide very little pretrial discovery." 800 Further, "even though state law provides extensive discovery, if that discovery is not available until after the critical time for plea settlements has passed, the preliminary hearing may still serve as the primary discovery vehicle for the substantial percentage of cases resolved by guilty pleas." 801 Moreover, "discovery" of the demeanor and other strengths and weaknesses of witnesses is something that is not obtainable from the prosecution's file no matter how liberal the state's discovery rules may be. Finally, "counsel can also be influential at the preliminary hearing in making effective arguments for the accused on such matters as the necessity for an early psychiatric examination or bail." $\$ 02$

Although the American Law Institute's Model Code of Pre-Arraignment Procedure provides that the right to a preliminary hearing

796. KAMISAR - 5th ed,, supra note 794, at 965; see also id. at 996-97.

797. Id. at 965; see also Graham \& Letwin, supra note 792, at 730.

798. KAMISAR - 4th ed., supra note 795, at 960.

799. Coleman, 399 U.S. at 9.

800. KAMISAR - 5th ed., supra note 794, at 967.

801. Id.

802. Coleman, 399 U.S. at 9. 
may not be terminated by the filing of an indictment, ${ }^{803}$ in practice, most state and federal prosecutors may avoid a preliminary hearing altogether by this technique. ${ }^{804}$ But "state prosecutors generally do not follow the common federal practice of 'mooting' almost all scheduled preliminary hearings by obtaining a prior indictment."805 Nor have the states responded to Coleman by the seemingly permissible move of abolishing preliminary hearings altogether. Thus, it is fair to conclude that the Court's ruling in Coleman has significantly extended the protection of personal rights of state criminal defendants.

ii. Misdemeanor trials. In 1972, when the Court decided Argersinger $y$. Hamlin, ${ }^{806}$ at least four or five states ${ }^{807}$ completely refused to appoint counsel for indigent misdemeanor defendants. Beyond this, determining the exact practice throughout the nation is complicated by several factors. Statewide laws were applied differently in different areas of some states; there were conflicting rules within certain states; and in other states that wholly forbade assignment of counsel, federal courts had ruled that lawyers must be provided for at least some indigent accused misdemeanants. ${ }^{808}$ Despite these ambiguities, it is plain that only a minority of the fifty states afforded indigents counsel in all (or virtually all) nonfelony prosecutions where imprisonment might result. ${ }^{809}$

The number of indigent misdemeanor defendants who subsequently obtained the assistance of a lawyer because of the Argersinger edict cannot, of course, be computed precisely. But it was unquestionably substantial. For example, in the city of Cleveland alone it was

803. Model Code of Pre-Arraignment Procedure $§ 330.1$ (American Law Institute 1975).

804. KAMISAR - 5th ed., supra note 794, at 979-80.

805. KAMISAR - 4th ed., supra note 795, at 975.

806. 407 U.S. 25 (1972) (holding that the sixth amendment right to counsel extended to trials for misdemeanors which might result in imprisonment).

807. See Brief for Petitioner at 17, 23, 25, 26-27, Argersinger v. Hamlin, 407 U.S. 25 (1972) [hereinafter cited as Brief for Petitioner]; S. KRANTZ, C. SMITH, D. ROSSMAN, P. Froyd \& J. Hoffman, Right to Counsel in CRIMINal CASES 694-701 (1976) [hereinafter cited as S. KRANTZ].

808. See Brief for Petitioner, supra note 807, at 18, 21, 26 (e.g., Louisiana, Nebraska, Virginia).

809. See generally Goldberg \& Hartman, Help for the Indigent Accused: The Effect of Argersinger, 30 N.L.A.D.A. BRIEFCASE 203, 205 (1972). In Maine, Montana, and Rhode Island the appointment of counsel was within the court's discretion. In Alabama counsel was assigned only for "serious" offenses or where "special circumstances" were found to exist. Other jurisdictions appointed counsel only when incarceration exceeded six months (Colorado, Florida, Idaho, Maryland, Nevada, New Mexico, North Carolina, Utah and Wisconsin), or 90 days (Michigan), or 60 days (Hawaii). Even in such states as Georgia, Indiana and Oklahoma, where statutes or judicial decisions required counsel in all cases, the rule was administered unevenly. See also Brief for Petitioner, supra note 807, at 11-28 (giving a slightly different breakdown of the state rules from that of Goldberg \& Hartman); S. KRANTZ, supra note 807, at 694-701. 
shown that 4,000 misdemeanor cases annually would be affected. ${ }^{810}$ Several broader estimates at the time, using different bases of calculation, found that between $1,000,000$ and $1,250,000$ persons annually charged with misdemeanors were without funds, ${ }^{811}$ and one of the studies concluded that prior to Argersinger perhaps as many as seventy-five percent of all those charged with misdemeanors went unrepresented. ${ }^{812}$

It is true that many of these people would not qualify under the potential limitation to Argersinger, established by Scott v. Illinois, ${ }^{813}$ that counsel must be appointed only when imprisonment is imposed. But it is equally beyond cavil that many of those indigents who did have lawyers provided at state expense at the time of Argersinger would not have had this benefit were it not for the Court's earlier right to counsel rulings. Thus, Alabama, which before Gideon v. Wainwright ${ }^{814}$ had appointed counsel only in capital cases, implemented Gideon by assigning lawyers not only for felonies but for serious misdemeanor offenses as well. ${ }^{815}$ The Supreme Court of Minnesota, in mandating the Argersinger approach as early as 1967, pointed to Gideon as the basis for its holding. ${ }^{816}$ Indeed, whereas at the time of the Gideon decision only five states required appointment of counsel for any misdemeanor, by 1970 twelve states did so for at least some and nineteen more did so for most misdemeanors. 817 By 1979, nearly forty states had either clearly or arguably adopted a standard which appointed lawyers in connection with any offenses for which imprisonment is authorized, whether or not it is actually imposed. ${ }^{818}$ Given the finding of one survey that "misdemeanants represented by attorneys are five times as likely to emerge from police court with all charges dismissed as are defendants who face similar charges without counsel,"819 it may fairly be said that the Argersinger rule, building as it did

810. See Portman, Gideon's Trumpet Blows for Misdemeanants - Argersinger v. Hamlin, The Decision and Its Impact, 14 SanTA ClarA LAW. 1, 14 (1973).

811. See id. at 18; Note, Dollars and Sense of an Expanded Right to Counsel, 55 Iowa L. REV. 1249, 1260 (1970).

812. Portman, supra note 810 , at 13 .

813. 440 U.S. 367 (1979).

814. 372 U.S. 335 (1963).

815. See Brief for Petitioner, supra note 807, at 11.

816. State v. Borst, 278 Minn. 388, 154 N.W.2d 888 (1967).

817. See Comment, Right to Counsel: The Impact of Gideon v. Wainwright in the Fifty States, 3 CREIGHTON L. REv. 103, 133 (1970). Within 18 months of the Argersinger ruling, some states (Arizona, North Carolina and South Dakota) moved to expand the announced right to encompass some misdemeanors when only a fine could result. See S. KRANTZ, supra note 807, at 694-701.

818. See Scott v. Illinois, 440 U.S. 367, $385-88$ (1979) (Brennan, J., dissenting).

819. AClU, Legal Counsel for Misdemeanants, Preliminary Report 1 (1970). 
on the progress already generated by Gideon, significantly affected the personal liberties of many Americans. Indeed, the fortunes of even those indigent misdemeanor defendants who are not assigned counsel as a result of the Argersinger-Scott mandate have been meaningfully improved by the Justices' decisions, for the state's refusal to appoint a lawyer for them means that, even if convicted, they cannot be incarcerated nor can those convictions be used to enhance prison sentences for any subsequent offenses. ${ }^{820}$

iii. Enhanced punishment. The criminal codes of most states and of the federal government provide that persons found guilty of some offenses may receive enhanced punishment if previously convicted of certain misdemeanors. ${ }^{821}$ In probably the most widespread example, one survey revealed that more than half the states' laws stipulate, "either generally or for specific offenses, that repeated serious traffic violations are punishable by an increased term of imprisonment." 822 In addition, minor crimes such as illegal entry of aliens, ${ }^{823}$ larceny of merchandise, ${ }^{824}$ possessing weapons ${ }^{825}$ or ammunition, ${ }^{826}$ petty theft, ${ }^{827}$ passing bad checks, ${ }^{828}$ misusing credit cards, ${ }^{829}$ distributing obscene materials, ${ }^{830}$ indecent exposure, ${ }^{831}$ and prostitution, ${ }^{832}$ are often treated as felonies if the defendant has previously been convicted of the same offense.

It is difficult to assess the full impact of the Court's ruling in Baldasar v. Illinois, 833 that, if an indigent defendant is denied appointed counsel for a misdemeanor conviction, that judgment cannot be used to increase his prison sentence for a subsequent offense. ${ }^{834}$

820. See Baldasar v. Illinois, 446 U.S. 222 (1980), discussed at notes $821-40$ infra.

821. Baldasar v. Illinois, 446 U.S. 222, 234-35 (1980) (Powell, J., dissenting).

822. Brief for the United States as Amicus Curiae at 5 n.7, Baldasar v. Illinois, 446 U.S. 222 (1980).

823. 8 U.S.C. § 1325 (1982).

824. 21 OKLA. STAT. ANN. tit. 21, §§ 1731(2), (3) (West 1983).

825. Cal. Penal Code $\S 12025$ (West 1982); N.Y. Penal Code $\S \S 265.01,265.02$ (McKinney 1980).

826. Cal. Penal Code $\S 12304$ (West 1982).

827. OHIO Rev. CODE ANN. § 2913.02 (Baldwin 1983).

828. OHIO REV. CODE ANN. § 2913.11 (Baldwin 1983).

829. OHo Rev. CODE ANN. § 2913.21 (Baldwin 1983).

830. Cal. Penal Code $\S \S 311.2,311.9$ (West 1970).

831. Cal. Penal Code $\$ 314$ (West 1970).

832. Cal. Penal Code § 647(b) (West 1970).

833. 446 U.S. 222 (1980).

834. There may be some uncertainty respecting this statement as the holding in Baldasar. Only four members of the Court, including the now retired Justice Stewart, specifically subscribed to this formulation of the rule. Justice Blackmun, who joined the Court's per curiam opinion in Baldasar, did so on the ground that counsel should have been appointed for defen- 
First, many persons accused of petty crimes will in fact have had a lawyer at their earlier trial, under the rule of Argersinger v. Hamlin ${ }^{835}$ and Scott v. Illinois. ${ }^{836}$ Moreover, a substantial number of states "provide counsel in all cases where imprisonment is authorized, even though counsel is not constitutionally required."837 Second, although apparently fewer than a dozen states had resolved the precise issue prior to the Baldasar decision, a majority of these correctly anticipated the Justices' conclusion. ${ }^{838}$ Nonetheless, in addition to Illinois, the rule in both New Jersey and Texas permitted prior uncounseled misdemeanor convictions to be used collaterally in recidivist proceedings, ${ }^{839}$ and all the state tribunals mentioned above that had held to the contrary did so pursuant to their understanding of the commands of the Court's earlier sixth amendment decisions. Thus, given the large number of habitual offenders potentially affected - an estimated 500 each year under the federal law regarding illegal entry of aliens alone ${ }^{840}$ - the Baldasar edict must be counted as significantly securing the personal rights of those accused of crime.

b. Sentence. As of the end of the 1960's, the statutes of the federal government and all states except Delaware authorized imprisonment of persons who were unable to pay a fine. ${ }^{841}$ Although there were no comprehensive statistics, evidence obtained from varied sources indicated that the number of such persons incarcerated was amazingly large - one widely cited estimate placing the figure at between $40 \%$ and $60 \%$ of all inmates in county jails. ${ }^{842}$ This led to the "conserva-

dant's original misdemeanor conviction because, even though no imprisonment resulted, it was "for an offense punishable by more than six months' imprisonment." 446 U.S. at 230 (Blackmun, J., concurring).

835. 407 U.S. 25 (1972); see notes 806-20 supra and accompanying text.

836. 440 U.S. 367 (1979).

837. Baldasar, 446 U.S. at 229 n.3 (Marshall, J., concurring) (emphasis added).

838. State v. Reagan, 103 Ariz. 287, 440 P.2d 907 (1968); Alexander v. State, 258 Ark. 633, 527 S.W.2d 928 (1975); Monroe v. Fincher, 305 So. 2d 108 (La. 1974); Commonwealth v. Barrett, 322 N.E.2d 89 (Mass. App. Ct. 1975); State v. Kirby, 33 Ohio Misc, 48, 289 N.E.2d 406 (Ct. Common Pleas 1972); Maghe v. State, 507 P.2d 950 (Okla. Crim. App. 1973); cf. Morgan v. State, $235 \mathrm{Ga} .632,221$ S.E.2d 47 (1975) (Argersinger applied retroactively).

839. State v. McGrew, 127 N.J. Super. 327, 317 A.2d 390 (1974); Aldrighetti v. State, 507 S.W.2d 770 (Tex. Crim. App. 1974). Cf. Nelson v. Tullos, 323 So. $2 d 539$ (Miss. 1975) (may imprison a convicted indigent for failure to pay a fine imposed without counsel after reasonable measures designed to aid payment prove unavailing).

840. Brief for the United States at 2, Baldasar v. Illinois, 446 U.S. 222 (1980). Statistics from California disclose that, in 1980, about 150 misdemeanants were subject to enhanced punishment because of prior misdemeanor convictions. Letter from Section Manager of Bureau of Criminal Statistics and Special Services to the author (Feb. 18, 1982).

841. See Note, Installment Payments: A Solution to the Problem of Fining Indigents, $24 \mathrm{U}$. FLA. L. REV. 166, 173 (1971).

842. S. Rubin, The LAw of Criminal Correction 286 (2d ed. 1973). A study of a Philadelphia prison in $1949-1950$ found that $60 \%$ of the 4140 defendants sentenced were committed 
tive estimate" that on any day nearly 28,000 persons would be in jail in the United States because they had failed to pay a fine. ${ }^{843}$

Two Supreme Court decisions in the early 1970's greatly affected this situation. In Williams v. Illinois, ${ }^{844}$ the Court held that equal protection forbade an indigent's imprisonment "beyond the maximum term specified by statute because of his failure to satisfy the monetary provisions of the sentence." 845 The Justices emphasized that they were only addressing this "narrow issue."846 But although two state statutes and a few court rulings had already conformed to the Williams principle, ${ }^{847}$ "[m]ost states permit[ted] imprisonment beyond the maximum term allowed by law, and in some there [was] no limit on the length of time one may serve for nonpayment."848 It was possible for states or cities to avoid the thrust of the Williams mandate either by increasing the maximum sentences for various offenses (and thus providing sentencing judges with more leeway), or by authorizing courts that heretofore could not impose jail terms (as many could not) ${ }^{849}$ to do so.

In Tate v. Short, ${ }^{850}$ however, the Court expanded the Williams rationale by adopting the position that equal protection prohibits indigents from being jailed for involuntarily "failing to make immediate

for nonpayment of fines. Note, Fines and Fining - An Evaluation, 101 U. PA. L. REv. 1013, 1022 (1953). In New Jersey, approximately 6,000 of the 18,000 persons jailed for misdemeanors and traffic offenses in 1961-1962 were sentenced in lieu of payments of fines. L. SiLVERSTEIN, supra note 791, at 123. Between 1960 and 1964, New York City courts imprisoned an average of about 25,000 persons annually because of their inability to pay fines. See Comment, Fines, Imprisonment, and the Poor: "Thirty Dollars or Thirty Days," 57 CaLIf. L. REv. 778, 787-88 n.86 (1969). In 1965, a 10-month survey of Baltimore prisons revealed that $80 \%$ of the 20,000 inmates were there for failure to pay fines. U.S. TASK FORCE ON THE ADMINISTRATION OF JUSTICE, PREsident's CoMmission on LAW ENFORCEMENT aND THE AdMinistration of Justice, TASK ForCe RePort: THE COURTS 124 (1967) [hereinafter cited as TASK ForCe REPORT: THE COURTS]. In addition, a 1969 study of the states of Arkansas and New Jersey and the city of Miami discovered that about $45 \%$ of all persons serving post-conviction jail terms were sentenced for nonpayment. Note, supra note 841 , at 169 . These statistics confirm earlier figures from national censuses and research in other cities. See Comment, supra, at 787.

843. Note, supra note 841, at 169.

844. 399 U.S 235 (1970).

845. 399 U.S. at 236.

846. 399 U.S. at 236.

847. See Sawyer v. District of Columbia, 238 A.2d 314 (D.C. Ct. App. 1968); People v. Saffore, 18 N.Y.2d 101, 218 N.E.2d 686, 271 N.Y.S.2d 972 (1966); Note, Imprisonment for Nonpayment of Fines - A Perplexing Problem Confronting State Legislatures, 23 BAYLOR L. REV. 328, 331 (1971) (Arizona and California).

848. Williams, 399 U.S. at 239.

849. See Tigar, The Supreme Court - 1969 Term, Foreword: Waiver of Constitutional Rights: Disquiet in the Citadel, 84 HARv. L. REV. 1, 52 n.37 (1970). Memphis was one city that pursued this course. Rossum, Problems in Municipal Court Administration and The Stress of Supreme Court Decisions: A Memphis Case Study, 3 AM. J. CRIM. L. 53, 79-80 (1974).

850. 401 U.S. 395 (1971). 
payment of any fine."851 Tate required instead that states first exhaust other collection aternatives such as installment payments. Although perhaps as many as ten states had previously authorized judges to accept payment of fines on the installment plan, ${ }^{852}$ none of these jurisdictions had required that indigents be given this opportunity. ${ }^{853}$ While research has not produced any nationwide data on our experience with the installment technique, both earlier and recent indications strongly suggest that Williams and Tate have greatly reduced the number of jailings for nonpayment $t^{854}$ and thus have markedly expanded the freedom of poor persons convicted of minor crimes throughout the nation. In addition, these rulings promise such ancillary benefits as alleviating overcrowded prison conditions, reducing the economic burden on the states of incarceration (perhaps approaching $\$ 100$ million annually), ${ }^{855}$ improving the collection rate for fines imposed, ${ }^{856}$ and ameliorating the "pervasive" belief, among ghetto residents particularly, that by imposing fines the judicial system discriminates against the poor. ${ }^{857}$

\section{Self-Representation}

Although, as of 1975, the right of a criminal defendant to represent himself at trial was provided by statute for federal prosecutions, guaranteed by the constitutions of thirty-six states and suggested by judicial decisions in several additional states, ${ }^{858}$ it was not universally secure. In California alone, where the right to dispense with the assistance of counsel was not recognized, research disclosed thirty-two published appellate cases between 1950 and 1970 (suggesting a much

851. 401 U.S. at 398 (quoting Morris v. Schoonfield, 399 U.S. 508, 509 (1970) (White, J., concurring)).

852. See Tate, 401 U.S. at 400 n.5; Williams, 399 U.S. at $244-45$ n.21; see also Note, supra note 842 , at 1023 n.71.

853. See Note, supra note 841 , at 174.

854. See Note, supra note 842 , at 1023 (After implementation of an installment procedure, "in Sweden, commitments for nonpayment fell from 13,358 in 1932 to 286 in 1946; in Britain, from an average of 83,187 for $1909-1913$ to 2,667 in 1946 . . . . In West Virginia, even in the midst of the depression, only $5 \%$ of those allowed to pay by installment had to be committed . . . ."); Note, Criminal Procedure - The Use of the Fine as a Criminal Sanction in New Jersey: Some Suggested Improvements, 28 RUTGERS L. REV. 1185, 1190, 1197 (1975) (only about $1 \%$ of defendants permitted to pay by instaliments were jailed for nonpayment); Comment, "Fines and/or Imprisonment": Pauper's Dilemmma or Delight?, 33 ARK. L. REV. 378, 388-89 (1979) (unlikely that any person in Arkansas who cannot pay will be imprisoned); Note, supra note 841, at $\mathbf{1 7 4 - 7 6}$ (experience in Delaware).

855. Note, supra note 841 , at 169 ; see also Comment, The " $\$ 30$ or 30 days" Fine as Applied to Indigents, 33 LA. L. REV. 671,680 (1973).

856. See Note, supra note 841, at $175-76$ (35\% improvement in Delaware).

857. See U.S. National AdVisory COMmission ON CIVIL Disorders, REPORT OF THE National Advisory COMMission ON Civil Disorders 337 (1968).

858. See Faretta v. California, 422 U.S. 806, 813-14 (1975). 
larger figure overall) in which the trial judge denied the accused's request to defend pro se. ${ }^{859}$ The usual justification for the defendant's motion was "dissatisfaction with his counsel (typically the public defender or appointed counsel) and even an express disagreement over trial strategy." 860

The contention that to deny the asserted constitutional right of self-representation - established in Faretta v. California ${ }^{861}$ - is "to impair the worth of great Constitutional safeguards by treating them as empty verbalisms" and "to imprison a man in his privileges" 862 is surely debatable. Objectively, it appears "undeniable that in most criminal prosecutions defendants could better defend with counsel's guidance" 863 and that "in all but an extraordinarily small number of cases an accused will lose whatever defense he may have if he undertakes to conduct the trial himself."864 Indeed, despite the fact that criminal trials usually result in convictions in any event, for most persons it may well be that the individual right afforded by Faretta is nothing other than "an instrument of self-destruction" 865 - probably even more so in the plea bargaining process than the formal proceeding itself. But none of this negates the right's operational value to some defendants, few as they may be.

Moreover, the importance of a constitutional safeguard must also be measured by the perceptions of its beneficiaries. Traditionally, defense lawyers have been empowered to make critical strategic decisions for their clients even when directly opposed by clients themselves - including waiver of such fundamental rights as speedy trial, crossexamination of adverse witnesses, subpoena of witnesses desired by the accused, withdrawal of an insanity plea, and objection to the introduction of illegally seized evidence. ${ }^{866}$ This being true, it is difficult to dispute the view of some defendants - exemplified by the plea of one that " '[i]f I'm going to be railroaded to the gas chamber at least let me be the engineer" " 867 - that by forcing him to be represented by counsel "the law contrives against him." ${ }^{868}$ This deeply ingrained objec-

859. Brief for Petitioner, app. A, at 6a-8a, Faretta v. California, 422 U.S. 806 (1975).

860. Id., app. A, at $2 \mathrm{a}$.

861. 422 U.S. 806 (1975).

862. Adams v. United States ex rel. McCann, 317 U.S. 269, 280 (1942).

863. Faretta, 422 U.S. at 834.

864. 422 U.S. at 838 (Burger, C.J., dissenting).

865. 422 U.S. at 840 (Burger, C.J., dissenting).

866. See authorities cited in Brief of Petitioner, supra note 859, at 18-21; see also Wainwright v. Sykes, 433 U.S. 72, 93 (1977) (Burger, C.J., concurring); Faretta, 422 U.S. at 820.

867. Brief of Amicus Curiae at 2, Faretta v. California 422 U.S. 806 (1975).

868. Faretta, 422 U.S. at 834. 
tion is overcome by the Court's ruling in Faretta, and those defendants who desire vindication of their right to proceed pro se have it protected by the Court and their liberty thus enhanced.

\section{Double Jeopardy}

a. Collateral estoppel. As of 1970, the doctrine of collateral estoppel - "the principle that bars relitigation between the same parties of issues actually determined at a previous trial" 869 - was a "safeguard firmly imbedded"870 for federal criminal trials. But the Supreme Court's decision of that year in Ashe v. Swenson, 871 holding that collateral estoppel was part of the double jeopardy prohibition which applied to the states, contravened the rule then existing in more than half the jurisdictions in the nation. ${ }^{872}$

It is true that $A$ she's impact may be significantly circumscribed by the fact that "[c]ollateral estoppel is unavailable to many defendants because of the difficulty in determining, from a general verdict, what issues were actually litigated and necessarily decided in the defendant's favor in the first trial." 873 The Court, however, was careful to emphasize that its edict was "not to be applied with the hypertechnical and archaic approach of a nineteenth century pleading book, but with realism and rationality." 874 And a series of subsequent decisions applying the $A s h e$ doctrine demonstrates its vitality. ${ }^{875}$ Moreover, had Ashe then been the law, subsequent prosecutions after acquittals in a number of earlier decisions - dealing, for example, with the alleged robbery of several persons at the same time $e^{876}$ - would most surely have been prevented. The collateral estoppel doctrine also forbids such frightening - but by no means purely hypothetical - possibilities as forcing an accused to run the gauntlet of successive prosecutions (until a conviction is obtained) for each of seventy-five hands of

869. Ashe v. Swenson, 397 U.S. 436, 442 (1970).

870. 397 U.S. at 446 n.10.

871. 397 U.S. 436 (1970).

872. See Annot., 9 A.L.R.3d 203, 228-30 (1966); See generally Case Comment, Collateral Estoppel: A Constitutional Guarantee, 50 B.U. L. REv. 604 (1970); Comment, Ashe v. Swenson: Collateral Estoppel, Double Jeopardy and Inconsistent Verdicts, 71 CoLUM. L. REv. 321 (1971).

873. Note, Double Jeopardy: Multiple Prosecutions Arising from the Same Transaction, 15 AM. CRIM. L. REV. 259, 282 (1978); see also Schaefer, Unresolved Issues in the Law of Double Jeopardy: Waller and Ashe, 58 CALIF. L. REv. 391, 394 (1970).

874. Ashe, 397 U.S. at 444.

875. See, e.g., Turner v. Arkansas, 407 U.S. 366 (1972) (per curiam); Johnson v. Estelle, 506 F.2d 347 (5th Cir.), cert. denied, 422 U.S. 1024 (1975); McDonald v. Wainwright, 493 F.2d 204 (5th Cir. 1974); United States v. Nash, 447 F.2d 1382 (4th Cir. 1971).

876. See, e.g., Hoag v. New Jersey, 356 U.S. 464 (1958); Johns v. State, 130 Miss. 803, 95 So. 84 (1923); Novak v. State, 139 Md. 538, 115 A. 853 (1921). 
poker played in a continuous game, ${ }^{877}$ or for each throw of the dice in an all night crap game..$^{878}$ Finally, although the $A$ she majority refused to take the further step - urged by Justices Brennan, Douglas and Marshall - of requiring the government "to join at one trial all the charges against a defendant that grow out of . . . [the] 'same transaction," "879 a number of state courts have since done so, ${ }^{880}$ thus affording some further evidence of the Court's influence in support of personal liberties.

In sum, Ashe's impact has certainly not been revolutionary. But there is sound reason to believe - especially in light of the recent "extraordinary proliferation of overlapping and related statutory offenses" and consequent ability of prosecutors "to spin out a startlingly numerous series of offenses from a single alleged criminal transaction" 881 - that the Court's ruling has been beneficial in reducing "the potential for unfair and abusive reprosecutions." 882

b. Insufficient evidence. As of the mid-1960's, the federal judici$\operatorname{ary}^{883}$ and the courts of at least ten states ${ }^{884}$ had adopted the position that the Constitution did not bar retrial of a criminal defendant after his conviction had been reversed on appeal for insufficient evidence to sustain the verdict of guilty at trial. Only the Supreme Court of New Mexico had held to the contrary ${ }^{885}$ and statutory and judicial language in other jurisdictions indicated that they would follow the prevailing rule. ${ }^{886}$ By the mid-1970's, several additional states had accepted the view that retrial under these circumstances was constitu-

877. Cf. Johnson v. Commonwealth, $201 \mathrm{Ky} .314,256$ S.W. 388 (1923) (each of 75 hands of poker in a single session treated as seperately punishable offenses).

878. Cf. Parks v. State, 57 Tex. Crim. 569, 123 S.W. 1109 (1909) (defendant previously convicted for the first throw in an all-night crap game can be separately tried for each subsequent throw).

879. 397 U.S. at 453-54 (Brennan, J., concurring).

880. See, e.g., People v. White, 390 Mich. 245, 212 N.W.2d 222 (1973); State v. Brown, 262 Or. 442, 497 P.2d 1191 (1972).

881. 397 U.S. at 445 n. 10 .

882. 397 U.S. at 445 n. 10 .

883. See Bryan v. United States, 338 U.S. 552 (1950).

884. See People v. Hardisson, 61 Cal. 378 (1882); People v. Benson, 24 Ill. 2d 159, 180 N.E.2d 483 (1962); State v. Bowman, 94 Iowa 228, 62 N.W. 729 (1895); State v. Phillips, 175 Kan. 50, 259 P.2d 185 (1953); Harris v. State, 158 Miss. 439, 130 So. 697 (1930); State v. Patton, 308 S.W.2d 641 (Mo. 1958); State v. Lamoreaux, 20 N.J. Super. 65, 89 A.2d 469 (1952); State v. Robinson, 100 Ohio App. 466, 137 N.E.2d 141 (1956); Cross v. Commonwealth, 195 Va. 62, 77 S.E.2d 447 (1953); Montgomery v. State, 136 Wis. 119, 116 N.W. 876 (1908); see also Thompson, Reversals for Insufficient Evidence: The Emerging Doctrine of Appellate Aquittal, 8 IND. L. REV. 497, 502 (1975).

885. State v. Moreno, 69 N.M. 113, 364 P.2d 594 (1961).

886. Comment, Double Jeopardy: A New Trial After Appellate Reversal for Insufficient Evidence, 31 U. CHI. L. REv. 365, 372 n.31 (1964). 
tionally forbidden. ${ }^{887}$ But other state courts reaffirmed the traditional doctrine, ${ }^{888}$ and the federal courts continued to adhere to the established principle - although some limited it to instances in which the defendant had moved for a new trial (rather than straightforwardly seeking a judgment of acquittal ${ }^{889}$ or where special equitable reasons existed ${ }^{890}$ for giving the prosecution "an opportunity for the proverbial 'second bite at the apple." "891

The Court's 1978 ruling in Burks v. United States ${ }^{892}$ - that the fifth amendment's prohibition against double jeopardy, made fully applicable to the states by the fourteenth amendment, ${ }^{893}$ forbids retrial after reversal of a conviction "solely for lack of sufficient evidence to sustain the jury's verdict," 894 whether or not "a defendant has sought a new trial as one of his remedies" 895 - therefore had substantial nationwide impact. Although there appears to be no compilation of the exact number of criminal convictions throughout the country that are overturned each year on the ground of insufficient evidence, perusal of the appellate reports from any state suggests the scope of the problem. While it is undoubtedly true that the number of retrials that actually take place after such judgments is but a fraction of the total, nonetheless it is fair to infer that, as a result of the Justices' decision in Burks, a great many persons will avoid the trauma and ordeal of actual and threatened reprosecution and possible conviction despite the government's having tried and failed to prove its case against them.

c. Successive state-municipal prosecutions. At the time of the Court's 1970 decision in Waller v. Florida, ${ }^{896}$ that successive state and municipal prosecutions for the identical criminal act conflicted with the constitutional prohibition against double jeopardy, about half the states ${ }^{897}$ permitted such prosecutions on the theory that the state and

887. See Hervey v. People, 178 Colo. 38, 495 P.2d 204 (1972); People v. Brown, 99 Ill. App. 2d 281, 241 N.E.2d 653 (1968); cf. State v. Torres, 109 Ariz. 421, 510 P.2d 737 (1973).

888. See, e.g., Gray v. State, 254 Md. 385, 255 A.2d 5 (1969), cert. denied, 397 U.S. 944 (1970).

889. See, e.g., United States v. Barker, 558 F.2d 899 (8th Cir. 1977); United States v. Robinson, 545 F.2d 301, 305 n.5 (2d Cir. 1976).

890. See, e.g., United States v. Wiley, 517 F.2d 1212 (D.C. Cir. 1975).

891. Burks v. United States, 437 U.S. 1, 17 (1978).

892. 437 U.S. 1 (1978).

893. Greene v. Massey, 437 U.S. 19, 24 (1978).

894. Burks, 437 U.S. at 2. The Court left open the question of whether retrial would be permissible if "the trial court committed error by excluding prosecution evidence, which, if received, would have rebutted any claim of evidentiary insufficiency." 437 U.S. at 5 n.4.

895. 437 U.S. at 17; see also Fudson v. Louisiana, 450 U.S. 40 (1981) (same rule applicable when trial judge grants new trial on ground of insufficient evidence).

896. 397 U.S. 287 (1970).

897. 397 U.S. at 391 n.3. 
its municipalities were "separate sovereign entities, each capable of imposing punishment for the same alleged crime." 898 But despite this large number of states technically affected by the Waller ruling, it appears that the actual occurrence of such prosecutions was relatively rare. ${ }^{899}$ Moreover, research subsequent to Waller indicates that its application has been significantly limited by its requirement that the prosecutions be for the "same offense" coupled with the ability of states and their municipalities to manipulate the definitions of statutory violations. ${ }^{900}$ Indeed, the defendant in the Waller case himself who, having removed a mural from the St. Petersburg City Hall, was first convicted for violating muncipal ordinances against destruction of city property and disorderly conduct and then found guilty of grand larceny by the state - was ultimately held responsible for all charges when, on remand, after the Supreme Court reversed the grand larceny conviction, the state courts held as a matter of Florida law that the municipal charges were not lesser included offenses of grand larceny and thus there was no double jeopardy after all.901

This is not to say, however, that the Justices' mandate in Waller is of no consequence. Within several months of the Waller ruling, at least two appellate courts, relying on its rationale, reversed state convictions that followed municipal prosecutions for similar misconduct. ${ }^{902}$ And adherence to Waller would surely have prevented such earlier results as permitting a state conviction for "theft of a jacket the value of [\$45]" after a municipal conviction for "theft of merchandise valued at $\$ 45$ from a New Orleans department store."903 Especially in light of the plausible inference that the dual prosecution technique had in the past often been used for such improper purposes as harassing unpopular defendants, ${ }^{904}$ it is fair to conclude that the Court's decision meaningfully assisted the cause of individual rights.

\section{Capital Punishment}

In 1976, the Court announced that the death penalty did not, in all

898. 397 U.S. at 391.

899. See Brief for Petitioner at 25, Waller v. Florida 397 U.S. 387 (1970).

900. See Comment, Double Jeopardy - Municipal Prosecutions as a Bar to Subsequent State Prosecutions for Offenses Arising from the Same Criminal Actions, 76 DICK. L. REV. 282, 285-93 (1972).

901. Waller v. State, 270 So. 2 d 26 (Fla. Dist. Ct. App. 1972).

902. See People v. Allison, 46 Ill. 2d 147, 263 N.E. 2d 80 (1970); Barrett v. State, 478 P.2d 1016 (Okla. Crim. App. 1970).

903. Louisiana ex rel. Ladd v. Middlebrooks, 270 F. Supp. 295, 295 (E.D. La. 1967).

904. See Brief for Petitioner at 25-26, Waller v. Florida, 397 U.S. 387 (1970). 
circumstances, violate the Constitution..$^{905}$ But other decisions in the early 1970's, in which the Court held that various forms of capital punishment contravene the eighth amendment, were of literally lifesaving importance to many people. The ruling in Furman v. Georgia, 906 invalidating the capital punishment laws of thirty-nine states and several federal statutory provisions, prohibited the execution of 633 prisoners on death row. ${ }^{907}$ "All were entitled to new sentences of life imprisonment, to a term of years, or, in a few cases, to new trials. The precise disposition was up to the state courts."908 None were put to death. ${ }^{909}$ As a result of Woodson v. North Carolina, ${ }^{910}$ in which the Court rejected mandatory capital punishment for specified offenses, 278 convicts had their death sentences rescinded.911

The consequences of the Justices' holding in Lockett v. Ohio; 912 which required that the sentencer consider all mitigating factors proffered by the defendant, are less precisely calculable. Since only nine of the thirty-four states that then had capital statutes conformed to this new standard, ${ }^{913}$ serious doubt was cast over the laws of the other states, ${ }^{914}$ whose death rows contained approximately 135 prisoners. ${ }^{915}$ What is clear, however, is that Lockett - and state court decisions from Pennsylvania and New York which anticipated its reasoning ${ }^{916}$ - preserved the lives of ninety-nine inmates in Ohio (precise numbers from New York and Pennsylvania are unavailable), ${ }^{917}$ apart from those others still to be tried before an acceptable death penalty statute is enacted.

Of probably greatest significance - at least for the future - is the

905. Gregg v. Georgia, 428 U.S. 153 (1976).

906. 408 U.S 238 (1972).

907. See M. Meltsner, Cruel and Unusual: The Supreme Court and Capital PUNISHMENT 292-98 (1973).

908. Id. at 293.

909. See Dobbert v. Florida, 432 U.S. 282, 309 (1977) (Stevens, J., dissenting). The experience of the 21 Massachusetts inmates affected by Furman is instructive: 18 had their sentences reduced, two were retried and acquitted, and one committed suicide. Commonwealth v. O'Neal, 339 N.E.2d 676, 694 n.2 (Mass. 1975).

910. 428 U.S. 280 (1976).

911. The Death Penalty Revived, TIME, July 12, 1976, 35, 35.

912. 438 U.S. 586 (1978).

913. See Lockett, 438 U.S. at 616-17 (Blackmun, J., concurring).

914. See, e.g., Jordan v. Arizona, 114 Ariz. 452, 561 P.2d 1224 (1976), vacated and remanded, 438 U.S. 911 (1978) (death sentence vacated based on Lockett).

915. NAACP Legal Defense Fund, Death Row, U.S.A. (June 20, 1978).

916. People v. Davis, 43 N.Y.2d 17, 400 N.Y.S.2d 735, 371 N.E.2d 735, 371 N.E.2d 456 (1977), cert. denied, 435 U.S. 998 (1978); Pennsylvania v. Moody, 476 Pa. 223, 382 A.2d 442, cert. denied, 438 U.S. 914 (1978).

917. NAACP Legal Defense Fund, supra note 915, at 7. 
Court's holding in Coker v. Georgia ${ }^{918}$ that the death sentence may not be imposed for the crime of rape of an adult woman. Coker's immediate effect was to save thirty-four persons then under such sentences from capital punishment. ${ }^{919}$ The number whose lives will be spared in years that follow may, of course, only be conjectured. But the fact that 455 people were executed for rape between 1930 and $1968^{920}$ foretells the substantial number of individuals potentially involved.

It may be that even those rulings that upheld capital punishment have "opened up new possibilities that with imaginative and resourceful litigation may avoid or nullify many death sentences."921 But there is no question that the Court's decisions upsetting death penalty laws have influenced in the most significant manner the personal liberties of thousands of people.

\section{Prisoners}

a. Disciplinary proceedings. Although there appear to be no national statistics on the number of charges of serious misconduct that are lodged against those incarcerated in America's prisons, ${ }^{922}$ data from two states suggest the importance of the matter. In 1973, when California's prison population was about 22,000 , over 20,000 disciplinary hearings were held; ${ }^{923}$ and figures from Georgia indicate a similar near equivalence between total inmates and annual disciplinary proceedings. ${ }^{924}$ Further, several surveys disclosed that a high proportion of such cases resulted in either forfeiture of "good conduct-time credit" (which is authorized in virtually all jurisdictions) ${ }^{925}$ or imposition of solitary confinement, or both. ${ }^{926}$ Probably an even more im-

918. 433 U.S. 584 (1977).

919. See H. Bedau, The Courts, the Constitution and Capital Punishment 112 (1977).

920. See Bureau of Prisons, National Prisoner Statistics, U.S. Dept. of Justice, Bull. No. 45, Capital Punishment 1930-1968, at 1 (1969).

921. Bedau, New Life for the Death Penalty, 233 The Nation Aug. 28, 1976 at 146. See, e.g., Eddings v. Oklahoma, 455 U.S. 104 (1982).

922. See Brief for Petitioner at 42, Wolff v. McDonnell, 418 U.S. 539 (1974).

923. Brief for Attorney General of California as Amicus Curiae at 8, Wolff v. McDonnell 418 U.S. 539 (1974).

924. Special Project, Behind Closed Doors: An Empirical Inquiry into the Nature of Prison Discipline in Georgia, 8 GA. L. REv. 919, 958 (1974) (there were about two or three hearings per week in prisons with an average of 167 prisoners each. Id. at 950 n.223, 958).

925. See Kraft, Prison Disciplinary Practices and Procedures: Is Due Process Provided?, 47 N.D. L. REV. 12 n. 24 (1970).

926. Note, The Problems of Modern Penology: Prison Life and Prisoners' Rights, 53 Iowa L. REv. 671, $690 \mathrm{n} .138,692 \mathrm{n} .154$ (1967) (approximately 60\% of dispositions in lowa in 1966 resulted in loss of good time and 50\% in solitary confinement, usually for 3 days); Special Project, supra note 924 , at 968 (23\% of hearings surveyed resulted in loss of good time and $57 \%$ in solitary confinement, usually for 14 days). 
portant sanction for a disciplinary action, albeit one that is often less formal, is the fact that the incident is usually "taken into account" in setting the date on which the prisoner's parole may be considered.

In Wolff v. McDonnell,927 the Court held that even though prison disciplinary proceedings do not implicate the full panoply of the rights of a defendant in a criminal prosecution, ${ }^{928}$ procedural due process does require designated protections when substantial penalties - such as loss of good time credits or solitary confinement - are imposed for misconduct.929 Although a 1974 American Bar Association survey, published on the eve of the Wolff ruling, found that nearly all prison systems in the United States claimed that they already adhered ${ }^{930}$ to the Justices' mandate that the accused prisoner receive written notice of the charges before the hearing, ${ }^{931}$ other due process minima announced by the Court required significant changes in many jurisdictions. Thus, at least fourteen states ${ }^{932}$ did not explicitly require "a written statement of the factfinders as to the evidence relied upon and the reasons for the disciplinary action taken."933 Only twenty-nine reporting states ${ }^{934}$ purported to provide that the inmate "be allowed to call witnesses . . . in his defense when permitting him to do so will not

927. 418 U.S. 539 (1974).

928. For example, neither the right to retained or appointed counsel nor the right to confront and cross-examine adverse witnesses apply. 418 U.S. at 567-70.

929. 418 U.S. at 571 n.19.

930. Resource Center on Correctional LaW and Legal SERVices, ABA Commission on Correctional Facilities and Services, Survey of Prison Disciplinary PracTICES AND PROCEDURES WITH AN ANALYSIS OF THE IMPACT OF Wolff $v$. McDonnell 11 (rev. Dec. 1974) [hereinafter cited as ABA Commission]. Although 48 of the 49 reporting jurisdictions declared that they provided this notice, there is substantial reason for skepticism as to the accuracy of these self-appraisals. The 48 respondents included Georgia and Nebraska, two of the very few states for which there was published empirical data. The contemporaneous Georgia study revealed that more than one-fifth of the inmates interviewed reported that they were first given notice of the charges against them at the time of the hearing itself. Special Project, supra note 924 , at 958 . In Wolff, the district judge found that Nebraska's practice often afforded the prisoner only oral notice shortly before the hearing. 418 U.S. at 558, 563-64.

Similarly, every prison system in the country reported that the accused prisoner is permitted to make a statement at the hearing, ABA CoMmission, supra, at 11, thus at least partially conforming to the Wolff requirement that the inmate be allowed to "present documentary evidence in his defense." 418 U.S. at 566. The Georgia study disclosed, however, that despite a state regulation guaranteeing an opportunity to explain or deny the charges, over one-fifth of the prisoners (and more than half of those from one of the three prisons examined) claimed that they were denied this right. Special Project, supra note 924, at 960.

931. 418 U.S. at 564.

932. See ABA Commission, supra note 930, at 56.

933. 418 U.S. at 563.

934. See ABA Commission, supra note 930, at 11. Again, empirical evidence from Rhode Island, which was one of the 29 states, contradicts its response to the survey. See Harvard Center for Criminal Justice, Judicial Intervention in Prison Discipline, 63 J. CRIM. L., CrIMINOLOGY \& POLICE SCI. 200, 213 (1972). 
be unduly hazardous to institutional safety or correctional goals,"935 and a majority of the federal circuits which had ruled on the issue held at that time that prisoners had no such constitutional right. 936

In order to assess adequately the impact of the Wolff decision, several large issues remain to be examined. First, experience from all regions of the country strongly indicates that prison officials have been especially recalcitrant in complying with judicial decrees expanding the constitutional rights of inmates. ${ }^{937}$ Moreover, the fact that within weeks of the Justices' ruling states such as Connecticut and Louisiana promulgated new disciplinary rules that provided even greater procedural protections than those mandated by the Court, ${ }^{938}$ affords no assurance that the reality has been significantly altered. For it has been observed that, as a matter of both theory and practice, "[c]orrectional administrators, if they so choose, could comply with court orders through changes which meet the letter of the court order, but not its spirit, and thereby frustrate the intent of the court."939 Nonetheless, the results of a survey of forty-two jurisdictions in 1980 disclosed that the response to Wolff by corrections agencies (and lower courts) has resulted in the articulation of substantial reforms beyond those set forth in the Court's opinion. ${ }^{940}$

However, even assuming that, despite the official antagonism de-

\section{418 U.S. at 566.}

936. 418 U.S. at 572 n. 20 .

937. See, e.g., Finney v. Arkansas Bd. of Corrections, 505 F.2d 194, 216 (8th Cir. 1974) (the prison superintendent allegedly stated "that appeals court ruling is nothing but a bunch of shit and don't mean nothing"); M. HARRIS \& D. SPILLER, AFTER DECISION: IMPLEMENTATION OF Judicial DeCREes in CORRectional SetTings 169-70 (Louisiana), 370-71 (Maryland) (1977); Harvard Center for Criminal Justice, supra note 934, at 222 (Rhode Island).

938. АВА Сомmission, supra note 930 (preface to rev. ed.).

939. Note, Judicial Intervention in Corrections: The California Experience - An Empirical Study, 20 UCLA L. REv. 452, 530 (1973).

940. Babcock, Due Process in Prison Disciplinary Proceedings, 22 B.C. L. Rev. 1009, 1014 (1981). At least three-quarters of the new prison disciplinary regulations "require that the inmates be informed of the rules of conduct," id. at 1017, with some specificity. Id. at 1018-21. Nearly one-fifth designate a maximum period that may pass between commission of the alleged offense and the time when the accused prisoner must receive notice of the charges, and most states require that the notice "must contain a complete description of the facts surrounding the incident." Id. at 1037. Although Wolff decreed no guarantee of either retained or appointed counsel, "[t] he response of the prison systems has been to offer a more liberal right to representation." Id. at 1039. Further, although there are perceived problems respecting the impartiality of adjudicators, a majority of jurisdictions stipulate that a member of the hearing panel "must be excused if he has participated in the investigation of the incident or been a witness thereto," $i d$. at 1060, and some have given real content to a right of confrontation and cross examination. Id. at 1074. Although the Justices did not mandate any internal appeal of disciplinary proceedings, all surveyed prison systems but one "have adopted some form of administrative review." Id. at 1083. Finally, nearly half the surveyed jurisdictions were found to have extended Wolff's procedural standards to the "imposition of lesser penalties," 418 U.S. at $571 \mathrm{n} .19$, such as transfers to other prisons, with California including administrative segregation. Babcock, supra, at 1094-95; cf. Hewitt v. Helms, 459 U.S. 460 (1983); Meachum v. Fano, 427 U.S. 215 (1976). 
scribed above, all of the Justices' requisites have been fully implemented, there is powerful evidence that this is of no tangible consequence to prisoners accused of serious misconduct. The fact appears to be that, especially when resolution of the matter turns on the conflicting testimony of the inmate and a prison officer, the former is rarely believed. ${ }^{941}$ As an Attorney General of California stated: "Because of their code of conduct, the credibility of virtually every inmate is questionable. What reason is there for allowing participation in due process hearings when the participant cannot be believed?"942 Maintenance of prison staff morale is, understandably, another factor for favoring their word over that of the convict. Indeed, a Georgia survey over a three-month period found that 1085 of 1087 disciplinary hearings produced a punitive action. ${ }^{943}$

However, practical results such as exoneration, meaningful as they are, may not be the sole measure of the value of the implementation of the right to due process. That fair procedures have significant intrinsic value beyond their important symbolic force is confirmed by the study of a Rhode Island corrections facility shortly after pre-Wolff judicially ordered improvements. Apart from a plainly "positive inmate response," 944 there

clearly were some objective manifestations of institutional change. Cases were dismissed where there were technical violations of the regulations, inmate witnesses were allowed in some cases, delays between charge and final hearing were minimized, and the extreme forms of punishment which instigated the imposition of the order were largely eliminated. ${ }^{945}$

Moreover, although appraisal of the causal relationship was complicated because a new warden took office at the same time, ${ }^{946}$ while "[b]efore the decree $30 \%$ of the dispositions involved segregation, [solitary confinement,] and $15 \%$ loss of good time," such sanctions "comprised only $19 \%$ and $7 \%$ respectively of the dispositions after the decree."947 Thus, while it is possible to conclude that the due process protections mandated by the Court in Wolff will have had some salutary effects on the rights of inmates, their precise extent and value is in need of further empirical investigation.

941. Harvard Center for Criminal Justice, supra note 934, at 213.

942. Brief for Attorney General of California as Amicus Curiae at 7 n.6, Wolff v. McDonnell, 428 U.S. 539 (1974).

943. Special Project, supra note 924, at 957 \& n.236.

944. Harvard Center for Criminal Justice, supra note 934, at 222.

945. Id. at 222 .

946. Id. at 214-16, 222 n.133.

947. Id. at 214. 
b. Good conduct credit. In Weaver v. Graham, ${ }^{948}$ the Court held that Florida's 1978 amendment to its "gain time for good conduct" statute was an unconstitutional ex post facto law. Prior to this time, convicts in the Florida prison system could earn good conduct credit of five days a month off the first and second years of their sentence, ten days a month off the third and fourth years, and fifteen days a months off all succeeding years. The 1978 amendment changed this 5-10-15 formula to 3-6-9. Since the state chose to apply this new schedule to previously convicted prisoners for all time they would serve after January 1,1979 , both the number of prisoners affected and the potential consequences for each were dramatic.

Statistics for the immediately preceding three years alone -1976 , 1977, and 1978 - revealed that more than 18,000 persons had been initially confined during that period whose sentences extended beyond the begining of 1979.949 To this must be added those convicts whose terms began earlier - and who therefore would lose the largest credits (only nine days a month instead of fifteen days). Petitioner's situation illustrates the additional incarceration time at stake. Under the original good conduct statute, Weaver, who had been sentenced to a term of fifteen years in 1976, had an anticipated release date of December 31,1984 . Under the amended law, he was scheduled to remain in prison until February 2, 1987 - more than twenty-five months longer. ${ }^{950}$

Even on the assumption that the Justices' ruling had no impact beyond the State of Florida, ${ }^{951}$ it undeniably avoided a substantial reduction of many convicts' chances to shorten their sentences simply by adhering to prison rules and adequately performing their assigned prison tasks.

\section{Parole and Probation Revocation}

The number of persons subject to revocation of probation or parole in the United States is huge. Although all figures must be seen as informed estimates at best, as of the mid-1960's, on any given day nearly 700,000 adults and juveniles who had been convicted of criminal offenses were on probation and over 100,000 felons who had been released from prison were on parole. ${ }^{952}$ By the late 1970's, both of

948. 450 U.S. 24 (1981).

949. Brief for Petitioner at 6 n.6, Weaver v. Graham, 450 U.S. 24 (1981).

950. 450 U.S. at 27 n.6.

951. This assumption is by no means of certain validity. See Greenfield v. Scafati, 277 F. Supp. 644 (D. Mass. 1967), affd., 390 U.S. 713 (1968).

952. PResident's COMmission on LAW ENForCEMent and Administration of JUS- 
these numbers had roughly doubled. ${ }^{953}$ Indeed, as of the end of 1981, the number of adult probationers had about tripled.954 Furthermore, a substantial portion - estimates run from about thirty-five percent to as high as forty-five percent - of all persons who are conditionally released or placed under community supervision have their probation or parole rescinded. ${ }^{955}$

The precise extent to which the states had afforded procedural due process rights to persons whose probation or parole they were seeking to revoke is difficult to ascertain. As for probation, a widely cited 1964 survey reported that the statutes of four jurisdictions (confirmed by judicial decisions in two) expressly authorized revocation without a hearing, and that in at least four additional states the courts had upheld revocation with no hearing whatever. ${ }^{956}$ No detailed review of probation revocation procedures appears to have been subsequently undertaken, but the matter of parole has been somehwat more thoroughly examined. In 1970, an update of earlier studies concluded that nine states provided neither notice nor a hearing prior to a parolee's recommitment to prison. ${ }^{957}$ Two years later, a Supreme Court review of statutes and judicial decisions observed that "very few states provide no hearing at all in parole revocations." 958 At the same time, a comprehensive national survey found "that by January, 1972 all juris-

TICE, TASK FORCE RePORT: CORRections 27 n.1, 186-87 (1967) [hereinafter cited as PRESIDENT'S COMMISSION].

953. U.S DePT. OF JUstice, SourCebook OF CRiminal Justice Statistics - 1976, at 668,703 (1977) (federal probationers and parolees) [hereinafter cited as CRIMINAL JusTICE STAtISTICS - 1976]; U.S. Dept. OF Justice, State aNd LocaI Probation aNd Parole SysTEMS 1 (Feb. 1978) (state and local probationers and parolees); NATIONAL CoUNCIL ON CRIME \& Delinquency, Parole In the UnIted States: 1979 (Aug. 1980) (adult parolees).

954. Compare Bureau of Justice Statistics, U.S. DePt. of Justice, Probation and PAROle 1981, at 2 (1,222,024 adult probationers as of Dec. 31, 1981), with PRESIDENT's COMMISSION, supra note 952, at 27 n.I (459,140 adult probationers as of Dec. 31, 1965). For 1982, see S.F. Chronicle, Sept. 19, 1983, at 10, col. 1 (1,335,359 adult probationers; 243,880 adult parolees).

955. See D. Stanley, Prisoners Among Us 106 (1976) (23\% of parolees); President's COMMISSION: CORRECTIONS, supra note 952, at 62 (35\%-45\% of parolees); TASK FORCE REPORT: THE COURTS, supra note 842, at $56 \mathrm{n} .28$ (108,000 of 431,000 adult probationers); CRIMINAL JUSTICE STATISTICS - 1976, supra note 953, at 748, 750, 760 (25\% of state male parolees; $22 \%$ of state female parolees; $23-40 \%$ of federal parolees); ABA RESOURCE CENTER ON CORrectional Law and Legal. Services, Survey of Parole Revocation Procedures i (1973) (10,000 of 44,000 parolees) [hereinafter cited as ABA]. See generally R. MCCLEARY, Dangerous Men: The Sociology of Parole (1978); P. SMith, Permission to be Slightrly Free: A Study OF the GRANTING, REFUSING AND WITHDRAWING OF PAROLE IN Canadian Penttentiaries (1976).

956. Sklar, Law and Practice in Probation and Parole Revocation Hearings, 55 J. CRIM. L., CRIMINology \& Police SCI. 175 (1964).

957. Cohen, Due Process, Equal Protection and State Parole Revocation Proceedings, 42 U. CoLO. L. REV. 197, 198 (1970).

958. Morrissey v. Brewer, 408 U.S. 471,488 n.15 (1972). 
dictions had chosen in fact to make use of some form of revocation hearing. Only four parole authorities (Iowa, Louisiana, Michigan, and Texas) did not grant parole-revocation hearings to all parolees facing return to incarceration . . . ."959

Assuming that the states followed a similarly progressive path in respect to affording hearings for persons charged with probation violations, the Court's rulings in Morrissey v. Brewer ${ }^{960}$ and Gagnon v. Scarpelli ${ }^{961}$ did not revolutionize the procedural rights of parolees and probationers. However, the decisions did significantly expand the individual liberties of these groups by bringing about "major restructuring" 962 of state practices. Almost all states had prejudiced an alleged parole violator's opportunity to rebut the charges by granting hearings only at a time well after the parolee's arrest and, indeed, only at the prison in which he had previously been incarcerated, a site that often was a considerable distance from the place in which the purported violation had occurred.963 In Morrissey and Gagnon, the Court sought to cure this defect by holding that due process requires that alleged probation and parole violators be granted a preliminary hearing after their detention at a place near the arrest and a final hearing before the ultimate decision on revocation. In addition, Morrissey and Gagnon imposed a series of procedural safeguards that many states theretofore had not provided. ${ }^{964}$

Within months of the Court's pronouncement, a study of parole boards in forty-five states concluded "that most of them are in formal compliance with most of the Morrissey requirements." 965 In addition,

959. O'Leary \& Nuffield, Parole Decision-Making Characteristics: Report of a National Survey, 8 CRIM. L. BuLL. 651, 668 (1972) (emphasis in original).

960. 408 U.S. 471 (1972).

961. 411 U.S. 471 (1973).

962. ABA, supra note 955 , at 2 .

963. See O'Leary \& Nuffield, supra note 959, at 668-69, 679; Van Dyke, Parole Revocation Hearings in California: The Right to Counsel, 59 CALIF. L. REv. 1215, 1220-21 (1971).

964. A survey of every parole board in the country - 54 in all - completed on the eve of the Morrissey decision revealed that, contrary to the Court's mandate, 19 did not grant the parolec notice of the specific charges, 22 did not permit the parolee to present witnesses, 26 denied the parolee the right to confront and cross-examine adverse witnesses, and 50 declined to afford the parolee a written statement of the evidence relied on and reasons for revoking parole. O'Leary \& Nuffield, supra note 959, at 671; see also O'Leary \& Hanrahan, Law and Practice in Parole Proceedings: A National Survey, 13 CRIM. L. BuLL. 181, 197 (1977). The data collected earlier on probation revocation hearings, although much less detailed, were not dissimilar. See Sklar, supra note 956 , at $192-93$.

965. ABA, supra note 955 , at 1 . Eighty percent of the 45 responding states were conducting on-site initial hearings and allowing "the parolee to present evidence and witnesses and to confront and cross-examine adverse witnesses." All these states also provided an impartial hearing officer. Thirty-four of the 36 (the other states not responding to this question) indicated that they also provided a final written statement of the reasons for decision. Two-thirds of these states were holding the initial hearing within ten days of notice or arrest, although some parole boards 
the federal government promptly revised its established parole and probation revocation procedures to comply with the conditions laid down in both Morrissey and Gagnon. ${ }^{966}$ By 1976, a survey of parole boards of all fifty states, the national government, and the District of Columbia disclosed unanimous conformity with virtually all the Court's requirements (although six jurisdictions provided only verbal explanation of their revocation decision). ${ }^{967}$

Furthermore, in 1972, over one-fifth of the parole boards refused to permit even retained counsel to be present at the revocation hearing and only twenty-six percent appointed lawyers for indigents. ${ }^{968}$ These statistics undoubtedly would have been less generous to the parolees ${ }^{969}$ were it not for the decision several years before, in Mempa v. Rhay, 970 that counsel is constitutionally required at sentencing even when sentencing is deferred to a probation revocation proceeding. The earlier and less comprehensive data for probation revocations were stronger but still indicated that fewer than half the states provided a lawyer for an indigent charged with probation violation. 971 The extremely important role of counsel for alleged parole and probation violators in effectuating such rights as presentation of evidence and cross-examination of witnesses was confirmed by professional observers ${ }^{972}$ of revocation hearings conducted between the time of the Morrissey decision (which did not reach the right to counsel issue) and the Court's ruling

took up to thirty days. As for the revocation hearing, all reporting jurisdictions used impartial review panels. Forty-one of the 45 states responding assured the parolee an opportunity to be heard and to present witnesses and evidence - nine of the states had instituted this practice in direct response to Morrissey, either shortly before or just after the decision was handed down in June 1972. Thirty-eight of the 45 states responding permitted confrontations and cross-examination - an immediate increase of ten states. Whereas just prior to Morrissey only four parole boards drafted a written statement justifying revocation, thirty-eight states did so afterward. One of the strongest points of compliance with the Court's edict was that at least 43 of the 45 reporting states now provided parolees written notice of specific charges, a change in practice for at least eight boards. Id. at 3-7, 10. Overall, of the 45 states replying to the survey, seven "expressly pointed out that they were currently involved in efforts to determine what their responsibilities under Morrissey consisted of and how they would implement changes required under that decision." Id. at 7.

966. See Fisher, Parole and Probation Revocation Procedures After Morrissey and Gagnon,

65 J. Crim. L., Criminology \& Police SCI. 46, 57 (1974).

967. See O'Leary \& Hanrahan, supra note 964, at 197-202.

968. O'Leary \& Nuffield, supra note 959, at 671, 673; see also O'Leary \& Hanrahan, supra note 964, at 197; Van Dyke, supra note 963, at 1221; Note, Parole Revocation in the Federal System, 56 GEO. L.J. 705, 719 (1968); Annot., 33 A.L.R.3d 272-82 (1970). These figures had not substantially changed in the forty-five state survey undertaken shortly after Morrissey was handed down. See ABA, supra note 955, at 19.

969. See O'Leary \& Nuffield, supra note 959, at 673.

970. 389 U.S. 128 (1967).

971. See L. Silverstein, Defense of the Poor in Criminal Cases in American STATE CourTS 143 (1965); Sklar, supra note 956, at 189, 192.

972. See D. STANLEY, supra note 955, at 114-15. 
in Gagnon (which held that due process requires the assistance of counsel under certain circumstances). Although in Gagnon the Court declined to impose an automatic right to retained and appointed counsel in all revocation hearings, its requirement of legal assistance when needed to assure a fair hearing will surely improve the lot of many probationers and parolees; in fact, Gagnon has led almost all jurisdictions to permit retained counsel as a matter of course and has prompted a majority - including California, New York, and the federal government ${ }^{973}$ - to provide appointed counsel without any showing of special need. 974

The Court's rulings have not eliminated all the procedural injustices, present or perceived, in the parole and probation revocation process. ${ }^{975}$ For example, it has been contended that, despite Morrissey's establishment of the right to confront and cross-examine adverse witnesses, the New York parole board "never produces any witnesses, other than parole officers . . . . The parole officer's testimony usually contains substantial amounts of hearsay, and violation charges are not infrequently sustained, solely or in large part, on the basis of hearsay."976 Nonetheless, the fact that the parole officer himself may be confronted at the hearing represents a significant advance over the revocation authorities' common previous practice of relying exclusively on written reports. 977 Moreover, at least some state courts have recently imposed strictures on hearsay evidence in revocation proceedings. 978 Further, at least in some instances, Morrissey and Gagnon have motivated reforms beyond the minimums stipulated - such as granting subpoena power to the parties in the revocation dispute, 979 excluding illegally seized evidence, ${ }^{980}$ permitting parolees some discovery rights prior to their revocation hearing, ${ }^{981}$ providing them an op-

973. See Fisher, supra note 966, at 57 (federal government); Lee \& Zuckerman, Representing Parole Violaters, 11 CRIM. L. BuLL. 327 (1975) (New York); Comment, The Impossible Dream? Due Process Guarantees for California Parolees \& Probationers, 25 HAstings L.J. 602, 630 (1974) (California).

974. O'Leary \& Hanrahan, supra note 964, at 199, 202.

975. See, e.g., Lee \& Zuckerman, supra note 973; see generally A. voN HiRsch \& K. HAN-

RAHAN, THE QUESTION OF PAROLE: Retention, REForM, OR ABolition? (1979).

976. Lee \& Zuckerman, supra note 973, at 331.

977. O'Leary \& Nuffield, supra note 959, at 674.

978. See, e.g., People v. Winson, 29 Cal. 3d 711, 631 P.2d 55, 175 Cal. Rptr. 621 (1980); Mason v. State, 631 P.2d 1051 (Wyo. 1981).

979. See Comment, Due Process for Parolees: Oregon's Response to Morrissey v. Brewer, 53 OR. L. REV. 57, 78 (1973).

980. Piccarillo v. New York State Bd. of Parole, 48 N.Y.2d 76, 397 N.E.2d 354, 421 N.Y.S.2d 842 (1979).

981. See O'Leary \& Hanrahan, supra note 964, at 201. 
portunity to appeal an adverse revocation decision, ${ }^{982}$ and applying certain due process rights to parole release hearings as well as to revocation proceedings. ${ }^{983}$ And parole officials' post-Morrissey statements that "fewer revocations are now proposed on the basis of technical violations,"984 further evidences the favorable and substantial impact on personal liberty that the Court's efforts in Morrissey and Gagnon produced.

\section{Juveniles}

a. Burden of proof. Prior to 1967, when the Supreme Court decided In re Gault, 985 a few state courts had held that proof "beyond a reasonable doubt" was required to convict at a juvenile hearing in which a minor was charged with conduct that would be a crime if committed by an adult.986 However, the overwhelming majority of jurisdictions had adopted a "preponderance of the evidence" standard.987 Gault did not address the question of what measure of proof was constitutionally required in these circumstances. However, in the three years between Gault's highlighting the issue of procedural safeguards in juvenile proceedings and the Court's ruling in In re Winship ${ }^{988}$ that the reasonable doubt test was demanded by due process, courts and legislatures in at least eight states chose to apply the more stringent standard on their own initiative. ${ }^{989}$ Under Gault's stimulus, acceptance of the reasonable doubt rule was urged by the National Conference of Commissioners on Uniform State Laws and by the Children's Bureau of the Department of Health, Education, and Welfare's

982. See id. at 203

983. See Comment, The Prisoner's Right to a Statement of Reasons for Parole Denial: Silence is not Always Golden, 24 BufFAlo L. REV. 567, 580 (1975); see also O'Leary \& Hanrahan, supra note 964, at 204.

984. D. STANLEY, supra note 955 , at 113.

985. 387 U.S. 1 (1967).

986. See People v. Fitzgerald, 244 N.Y. 307, 155 N.E. 584 (1927); Jones v. Commonwealth, 185 Va. 335, 38 S.E.2d 444 (1940). The New York Legislature subsequently withdrew this rule in favor of a "preponderance of the evidence" test. N.Y. Fam. Ct. Act $\$ 744(\mathrm{~b})$ (McKinney 1963) (amended in 1976 to reflect In re Winship, 397 U.S. 358 (1970)).

987. See Cohen, The Standard of Proof in Juvenile Proceedings: Gault Beyond a Reasonable Doubt, 68 Mich. L. REv. 567, 600 n.128 (1970); Note, supra note 294, at 795.

988. 397 U.S. 358 (1970).

989. See Thomas v. State, 121 Ga. App. 91 , 172 S.E.2d 860 (1970); In re Urbasek, 38 Ill. $2 d$ 535, 232 N.E.2d 716 (1967); Colo. Rev. STAT. \$ 22-3-6 (Supp. 1967); MD. ANN. CoDE art. 26, $\S$ 70-18(a) (Supp. 1969); N.J. Cr. RuLES 5:9-9 (1969); N.D. CENT. CODE § 27-20-29(2) (1969); WASh. JUV. Cr. Rules 4.4(b) (1969); Steinfeldt, Kerper \& Friel, The Impact of the Gault Decision in Texas, 20 Juv. CT. JuDGEs J. 154, 156 (1969); see also United States v. Costanzo, 395 F.2d 441 (4th Cir. 1968), cert. denied, 393 U.S. 883 (1968). 
Social and Rehabilitation Service.990 Nonetheless, it remained for the Justices' mandate in Winship to impose the traditional criminal law standard on approximately four-fifths of the states.

There is no conclusive evidence for the proposition that the Court's decision has significantly improved the condition of individual liberty for alleged juvenile offenders, but the available data strongly suggest it. In surveying reactions to the different quantum of proof requirements, sitting judges were asked "to translate into probability statements their sense of what it means to be convinced by a preponderance of the evidence, and to be convinced beyond a reasonable doubt." When responding to questionnaires, at least, the judges thought there was an important difference: almost a third of the responding judges put "beyond a reasonable doubt" at $100 \%$, another third put it at $90 \%$ or $95 \%$, and most of the rest put it at $80 \%$ or $85 \%$. For the preponderance standard, by contrast, over half put it at $55 \%$, and most of the rest put it between $60 \%$ and $75 \%$. Questionnaires sent to jurors and students produced slightly lower results for the reasonable doubt instruction, and rather higher results for the preponderance standard; still, for most people the distinction was clear.991 Indeed, in the Winship case itself, in which the Court invalidated New York's preponderance of the evidence rule, the juvenile judge had acknowledged that the proof of the alleged larceny "might not establish guilt beyond a reasonable doubt." 992 Thus, it is fair to infer that the Winship ruling has had an important impact on the liberty of juveniles charged with delinquency.

b. Reprosecution as adult. Prior to the Court's decision in 1975 in Breed v. Jones, ${ }^{993}$ about five states explicitly protected a minor from being prosecuted in a criminal court for an offense on which evidence had already been heard against him in a juvenile court adjudicatory hearing. ${ }^{994}$ Nine additional jurisdictions achieved the same result by providing that if the youth were old enough to be tried in a regular criminal prosecution, then the juvenile court must make the decision

990. See Uniform Juvenile Court Act § 29(b) (1968); W. SHERIDAN, LeGisLATIVE Guide FOR DRAFTING FAMILY AND JUVENILE COURT ACTS § 32(c) (1969).

991. Underwood, The Thumb on the Scales of Justice: Burdens of Persuasion in Criminal Cases, 86 YALE L.J. 1299, 1311 (1977) (footnotes omitted) (referring to Simon, Judges' Translations of Burdens of Proof into Statements of Probability, TRIAL LAw. GUIDE, Nov. 1969, at 29, and to Simon \& Mahan, Quantifying Burdens of Proof: A View from the Bench, the Jury, and the Classroom, 5 LAW \& Socy. REv. 319 (1971)).

992. 397 U.S. at 360.

993. 421 U.S. 519 (1975).

994. See State v. Gibbs, 94 Idaho 908, 500 P.2d 209 (1972); State v. Halverson, 192 N.W.2d 765 (Ia. 1971); Juvenile Court Act § 2-7(3), ILL. REv. STAT. ch. 37 \$ 702-7(3) (Supp. 1984); MiNN. JUV. CT. RULES 8-1(2) (1983); N.M. STAT. ANN. § 13-14-25 (1976). 
to transfer its jurisdiction before the delinquency proceeding takes place.995 Further, the statutes of approximately twenty more states, by ruling that evidence introduced in a juvenile court adjudicatory hearing is inadmissible against the minor in a subsequent adult criminal prosecution, ${ }^{996}$ made it quite difficult — but not impossible 997 to subject the youth to two trials for the same offense. In all other states, a youthful offender could be tried in criminal court after a juvenile proceeding against him for the same offense had begun and, indeed, even after he had been found to be a delinquent because of it. ${ }^{998}$ Breed eliminated this possibility, holding that jeopardy attaches when the juvenile court begins to hear evidence to adjudicate whether a minor has committed acts that constitute a crime and that a subsequent criminal prosecution for this offense violates the constitutional prohibition against double jeopardy.

It may well be that, as a result of the Breed ruling, some juvenile judges will, on the basis of grossly incomplete evidence, transfer minors to adult criminal courts, thus subjecting them to potentially more serious consequences, whereas this would not have been done if a full adjudicatory hearing had first been held in juvenile court.999 However, this clearly need not be true because the Court's opinion in Breed plainly did not foreclose states "from requiring, as a prerequisite to the transfer of a juvenile, substantial evidence that he committed the offense charged, so long as the showing required is not made in an adjudicatory proceeding." 1000

More likely, Breed's principal thrust, so far as personal liberty is concerned, should be twofold. First, it will ameliorate the unfair prosecutorial advantage of having the state hear the accused youth's full defense in the juvenile court proceeding prior to his being tried as an adult offender. Second, and more importantly, it will remedy the practice - occurring in a number of reported cases - of youths who have already been adjudicated delinquents being criminally prosecuted for the same offense because of misbehavior while confined in a juvenile correctional institution. ${ }^{1001}$

995. See Rudstein, Double Jeopardy in Juvenile Proceedings, 14 WM. \& MARY L. REV. 266, 299 n.134 (1972), and the statutes collected therein.

996. See Rudstein, supra note 995 , at 293 n.119, and statutes cited therein. Massachusetts subsequently changed its rule. See In re a Juvenile, 306 N.E.2d 822 (Mass. 1974).

997. See Carter v. Murphy, 465 S.W.2d 28 (Mo. Ct. App. 1971).

998. See Carr, The Effect of the Double Jeopardy Clause on Juvenile Proceedings, 6 U. ToL. L. REv. 1, 57-59 (1974); Milton, Post Gault: A New Prospectus for the Juvenile Court, 16 N.Y.L.F. 57, 72 (1970); Rudstein, supra note 995, at 298-300.

999. See Carr, supra note 998 , at $48-54$.

1000. 421 U.S. at 538 n. 18.

1001. See, e.g., Hultin v. Beto, 396 F.2d 216 (5th Cir. 1968); Sawyer v. Hauck, 245 F. Supp. 
The exact number of Breed's beneficiaries is unknown, but statistics for just one year preceding the decision, showing that in California alone 764 youthful offenders were ultimately subjected to regular criminal prosecution, ${ }^{1002}$ indicate that the Court's ruling affords meaningful protection for the individual rights of substantial numbers of juveniles.

\section{B. Commitment of Mentally Ill \\ 1. Incompetency To Stand Trial}

As of the early 1970's, every state in the nation authorized the commitment to a mental institution of criminal defendants found to be incompetent to stand trial. ${ }^{1003}$ About five jurisdictions conditioned such detention on a determination that the accused was "dangerous" and several others placed the commitment decision within the court's discretion, ${ }^{1004}$ but in at least four-fifths of the states, accused persons who were found to be insufficiently intelligent or communicative to be able to assist in their own defense could be indefinitely institutionalized. Institutionalization was permissible even though they had never been convicted of any crime, were not "insane" or "dangerous" by any legal definition, and had never been afforded the procedures of a standard civil commitment. ${ }^{1005}$ It was reported that the criteria for confinement in these incompetency proceedings "are often unclear or not adhered to. Expert testimony is relatively unchecked and does not appear to be subject to limitations such as those imposed in determina-

55 (W.D. Tex. 1965); Bryan v. Superior Court, 7 Cal. 3d 575, 498 P.2d 1079, 102 Cal. Rptr. 831 (1972), cert. denied, 410 U.S. 944 (1973); People v. Silverstein, 121 Cal. App. 2d 140, 262 P.2d 656 (1953); State v. R.E.F., 251 So. 2d 672 (Fla. Dist. Ct. App. 1971), affd. per curiam, 265 So. 2d 701 (Fla. 1972); Moquin v. State, 216 Md. 524, 140 A.2d 914 (1958); In re Smith, 114 N.Y.S.2d 673 (Dom. Rel. 1952); Lewis v. Commonwealth, 214 Va. 150, 198 S.E.2d 629 (1973); Brooks v. Boles, 151 W. Va. 576, 153 S.E.2d 526 (1967); see also Note, Double Jeopardy and the Waiver of Jurisdiction in California's Juvenile Courts, 24 STAN. L. Rev. 874, 882 (1972) (describ. ing an instance in which a minor was removed from a juvenile detention facility and held in county jail for more than a year pending his criminal trial).

1002. See Edwards, The Case for Abolishing Fitness Hearings in Juvenile Court, 17 SANTA Clara L. REV. 595, 611 \& n.107 (1977).

1003. See S. Brakel \& R. Rock, The Mentally Disabled and the Law 444-53 (Am. Bar Found. rev. ed. 1971).

1004. See Jackson v. Indiana, 406 U.S. 715, 733 (1972); S. BRAKEL \& R. Rock, supra note 1003, at 444-53; Burt \& Morris, A Proposal for the Abolition of the Incompetency Plea, 40 U. CHI. L. REv. 66, 66 n.4 (1972).

1005. See Jackson v. Indiana, 406 U.S. 715, 719 (1972); S. BRAKEL \& R. Rock, supra note 1003, at 415; see generally Goldstein, The Mentally Disordered Offender and the Criminal Law, in The Mental y AbNoRmal OFFender 188 (A. de Reuck \& R. Porter eds. 1968) (discussion of the use of competency hearings and civil commitment to accomplish preventive detention); Rosenberg, Competency for Trial - Who Knows Best?, 6 CRIM. L. Bull. 577 (1970) (comparison of medical and legal criteria for determining competency). 
tion of criminal responsibility or need for civil commitment."1006 In a majority of cases observed in one study, "the court and the defense counsel both did little more than to accept the hospital recommendation and to question the medical witness in a perfunctory manner."1007

The number of such people involved was dramatic. In 1967, fourteen percent of all persons sent to state mental institutions after being charged or convicted of crimes were committed as incompetents. ${ }^{1008}$ The

patient population of Matteawan State Hospital for the criminally insane in New York was 2142 in November 1962. Of these, 1167 or $54.5 \%$, had been admitted as incompetent to stand trial. By 1966 the Matteawan population had shrunk to 838 patients, but $565(68 \%)$ of them were committed for incompetency. Ionia State Hospital in Michigan had 1,484 patients in August, 1960; 755 or $57 \%$ of these were there because they were held incompetent. ${ }^{1009}$

Ordinarily, the defendant remained hospitalized until the director of the facility in which he had been confined certified that he had regained competency. ${ }^{1010}$ Such certification occurred only rarely in practice. It was reported that " $[t]$ he hospitals that harbor incompetent patients almost inevitably employ criteria of release which have to do with the patient's ability to go back to the community - an inappropriate standard since what is at issue is the accused's competency to stand trial."1011 Incompetents were generally housed in hospitals for the criminally insane, "usually the poorest available facilities."1012 Since considerations of security and custody were paramount, the treatment afforded the incompetent was minimal — "usually less than if he had been civilly committed to a mental institution."1013 Indeed, there was "evidence that he would more likely be given the proper treatment in prison, since some penal institutions [were] more willing to recognize the value of treatment methods of other disciplines such as psychology and sociology." 1014 The modest treatment that was pro-

1006. S. BRAKEL \& R. Rock, supra note 1003, at 412.

1007. Rosenberg, supra note 1005, at 586; see also A. Matthews, Mental Disability AND the CRIMINAL LAW 75 (1970).

1008. See Burt \& Morris, supra note 1004, at 66 n.1.

1009. Comment, An End to Incompetency to Stand Trial, 13 SANTA ClaRA LAw. 560, 574 (1973) (footnotes omitted).

1010. See S. Brakel \& R. Rock, supra note 1003, at 416; Bennett, Competency to Stand Trial: A Call for Reform, 59 J. CRIM. L., CRIMINOLOGY \& Police SCI. 569, 572 (1968); Note, Incompetency to Stand Trial, 81 HARV. L. Rev. 454, 471 (1967).

1011. S. BRAKel \& R. Rock, supra note 1003, at 417.

1012. Bennett, supra note 1010, at 571 (footnote omitted).

1013. Id; see also S. BRAKEL \& R. Rock, supra note 1003, at 412.

1014. Bennett, supra note 1010, at 571 (footnote omitted). 
vided was often misdirected. ${ }^{1015}$ Finally, empirical studies indicated that the incompetent accused defendant was "less likely to gain release after making comparable progress toward recovery than if he were in a civil institution,"1016 and that the longer he was institutionalized the worse his condition became. ${ }^{1017}$ As a result of all these factors, although a handful of states authorized conditional release of incompetent defendants on parole, ${ }^{1018}$ in most instances their hospitalization extended for exceedingly long periods - usually even more prolonged than for persons civilly committed. ${ }^{1019}$

1015. Id. "One field study reports the case of a twenty-five-year-old male who was held as an incompetent patient for four years while hospital personnel worked toward his achieving 'insight into his behavior' and, even more inappropriately, "confession of his crime.' " S. BRAKEL \& R. Rock, supra note 1003, at 417 (footnote omitted). See also Rosenberg, supra note 1005, at 588.

1016. Bennett, supra note 1010, at 571-72 (footnote omitted).

1017. See McGarry, The Fate of Psychotic Offenders Returned for Trial, 127 AM. J. PsYCHIATRY 1181, 1183 (1971).

1018. See S. BRAKEL \& R. Rock, supra note 1003, at 444-53.

1019. See the data cited in Jackson v. Indiana, 406 U.S. 715, 734 n.16. A seven-year observational study in Massachusetts found "that the average confinement of those committed as incompetents was sixty-one months while the average hospital stay of those who were civilly committed was only fourteen months. One in six of the incompetent defendants had been returned to the community, but every member of the civilly committed group had been discharged to the community." Burt \& Morris, supra note 1004, at 77 n.45 (citing McGarry \& Bendt, Criminal vs. Civil Commitment of Psychotic Offenders: A Seven-Year Follow-up, 125 AM. J. PsYchIATRY 1387 (1969)). In New York's Matteawan Hospital for the criminally insane, a 1965 survey revealed that " 19 percent (208) of those confined as incompetent to stand trial had been there for twenty years or more, and 8 percent (89) had been there for thirty years or more." Id. at 78 n.49 (citing Mental Illness, Due Process and the Criminal Defendant: A Second RePORT AND ADDITIONAL RECOMMENDATIONS BY THE SPECIAL COMMITTEE ON THE STUdY OF COMMITMENT PROCEDURES AND THE LAW RELATING to INCOMPETENTS OF THE AsSOCIATION OF THE BAR OF THE CITY OF NEW YORK 214-17 (tables 8 \& 9) (1968)). Indeed, in New York

there were several cases of persons committed as incompetent but not released even though the charges against them had been dismissed; either word of the dismissal simply never reached the hospital or the hospital did not act. In New York City when the courts were reorganized in 1963, all indictments outstanding twenty years or more were dismissed. Defendants committed to Matteawan occasionally wrote to the New York City courts about their status. The court clerk who answered these letters .... [said] there were scores of cases like this but that there was no one to take the initiative to have these patients discharged.

A. MATTHEws, supra note 1007 , at 138 n.3. In Massachusetts' Bridgewater facility, where an independent psychiatric study judged that one-third of those committed were actually capable to stand trial, it was found that this one-third of the population had been held for an average of over four years; the other two-thirds had spent an average of nearly 15 years in custody; more defendants committed as incompetent "left Bridgewater by dying than by all other avenues com. bined." McGarry, supra note 1017, at 1181, 1183. In Washington, D.C.'s St. Elizabeth Hospital, $58 \%$ of the committed incompetents remained for more than a year, $23 \%$ more than three years, $11 \%$ more than five years. See JUDICIAL CONFERENCE OF THE DISTRICT OF COIUMBIA CIRCUIT, RePoRt OF THE COMMITTEE ON PROBleMS CONNECTED WITH MENTAL EXamination of the ACcuSEd in CRiminal CASES, Before Trial 161 (table 15) (1966). Even New York, one of the very few jurisdictions which had placed time limits on these detentions, see Burt \& Morris, supra note 1004, at $67 \mathrm{n} .4$, permitted incompetent felony defendants to be hospitalized for two-thirds of the maximum sentence for the offense charged. N.Y. CRIM. Proc. LAW § 730.50(3) (McKinney 1971). 
The Court's ruling in Jackson $v$. Indiana ${ }^{1020}$ ended these intolerable restrictions on personal liberty. It held

that a person charged by a State with a criminal offense who is committed solely on account of his incapacity to proceed to trial cannot be held more than the reasonable period of time necessary to determine whether there is a substantial probability that he will attain that capacity in the foreseeable future. If it is determined that this is not the case, then the State must either institute the customary civil commitment proceeding that would be required to commit indefinitely any other citizen, or release the defendant. Furthermore, even if it is determined that the defendant probably soon will be able to stand trial, his continued commitment must be justified by progress toward that goal. ${ }^{1021}$

Even if Jackson influences trial judges to more readily find defendants competent to be tried, this will likely be the lesser evil.

If an incompetent defendant were to stand trial, his interests would be represented by his retained or appointed counsel rather than by a prosecutor, judge or court-appointed psychiatrist. Surely in view of the basic assumptions of our adversary system and the sorry consequences to an incompetent of a pre-Jackson non-adversary commitment, it will be to his advantage to stand trial, even if arguably incompetent. ${ }^{1022}$

In addition, "[p]ostponement of the trial often results in loss of evidence, which may well be more damaging to the defendant than to the prosecution." 1023 Finally, even if the accused is convicted, the data indicate that more likely than not the criminal sentence will be shorter and less severe than the indefinite incompetency incarceration. ${ }^{1024}$

If, on the other hand, the State seeks to civilly commit the defendant, this would also appear to be a marked improvement. In terms of procedure, as indicated above, the protection afforded will likely be greater. As a matter of substantive criteria, both state law and the Supreme Court's subsequent mandate in $O^{\prime}$ Connor v. Donaldson ${ }^{1025}$ (under which Jackson himself probably could not have been confined) ${ }^{1026}$ will ordinarily impose a stricter commitment standard and a more lenient standard of release. ${ }^{1027}$ Finally, as has also been observed above, if the accused is in fact civilly committed, the strong likelihood is that the institution will be much less undesirable, his treatment much more appropriate, his privileges much greater and his period of

1020. 406 U.S. 715 (1972).

1021. 406 U.S. at 738.

1022. Comment, supra note 1009, at 572. Cf. Rosenberg, supra note 1005.

1023. S. BRAKEI \& R. RocK, supra note 1003, at 412.

1024. See Note, supra note 1010 , at 456.

1025. 422 U.S. 563 (1975). See generally text at notes 1029-55 infra.

1026. See Jackson, 406 U.S. at 729.

1027. 406 U.S. at 730. 
confinement much shorter. ${ }^{1028}$ Thus, the mandate of Jackson significantly enhanced the protection of the rights of that sizeable class of individuals whose competency to stand trial is doubtful.

\section{Continued Involuntary Institutionalization}

As of the early 1970's, statutes in all states provided that persons might be civilly committed to public mental institutions against their will. 1029 Although there were some indications that the annual number of involuntary admissions was declining, ${ }^{1030}$ and estimates of the exact number of such persons so confined at any time varied somewhat, there was no dispute that the figure was very large - ranging from about 500,000 to over $700,000 .{ }^{1031}$ Statutory criteria justifying involuntary commitment differed significantly, but as of 1974 less than one-third of the states limited involuntary commitment to persons who were either unable to care for their physical needs or were dangerous to themselves or others. ${ }^{1032}$ The great majority of jurisdictions authorized compulsory confinement for much less compelling reasons, such as whether the individual was in need of care or treatment or was a fit subject for hospitalization. ${ }^{1033}$ Moreover, some states adopted even looser criteria for justifying a refusal to release involuntarily confined persons than for justifying their initial commitment. ${ }^{1034}$

For several reasons, it is not possible to assess accurately the precise extent of the effect of the Supreme Court's 1975 decision in O'Connor v. Donaldson, ${ }^{1035}$ which delineated a substantive "constitutional right to liberty"1036 for those held involuntarily in mental institutions. First, regardless of the scope of this personal right, the magnitude of the ruling's impact on individual liberty is reduced

1028. See Bennett, supre note 1010, at 571.

1029. Note, Civil Commitment of the Mentally Ill, 87 HARV. L. REv. 1190, 1202-05 (1974).

1030. A. Stone, Mental Health and Law: A System in Transition 43 (1976); Note, supra note 1029, at 1193 n.3.

1031. See Steinzor, Kenneth Donaldson's Fight for Freedom, THE Progressive, Apr. 1977, at 48, 50 (NIMH statistics indicate "that out of 1,600,000 live-in patients . . . at least 480,000 were involuntarily committed"); Brief of New Jersey as Amicus Curiae at 2, O'Connor v. Donaldson, 422 U.S. 563 (1975) (approximately 60\% in New Jersey); Brief of Ohio as Amicus Curiae at 1, O'Connor v. Donaldson, 422 U.S. 563 (1975) (approximately 50\% in Ohio); Note, Involuntary Civil Commitments - How Heavy is the Burden?, 29 BAYLOR L. REv. 187, 187 (1977) (almost 50\% of admissions to Texas state mental hospitals in 1975-1976 were involuntary); Note, supra note 1029, at $1193 \mathrm{n.3}$ (of 404,000 patients admitted in 1972, 41.8\% were involuntarily committed).

1032. Note, supra note 1029, at 1203 n.11.

1033. Id. at 1203-04.

1034. Id. at 1385-86.

1035. 422 U.S. 563 (1975).

1036. 422 U.S. at 573. 
somewhat by the relatively short time that the average person is likely to be confined. For example, in 1971, " $86.9 \%$ of the total number of voluntary and involuntary patients who were admitted to state and county mental hospitals were discharged within 6 months of admission," and "the median length of stay in these hospitals was 41 days." 1037 These naked statistics, however, should not mask $O^{\prime}$ Connor's potential importance for the substantial number of mental patients whose much longer deprivation of freedom is submerged in the calculations. ${ }^{1038}$

However, the major obstacle in determining $O^{\prime}$ Connor's direct consequences for individual rights is the extremely restricted scope of the Court's opinion. The record showed that Donaldson posed no danger to himself or others, had the capacity to earn his own living outside the institution in which he had been confined, had responsible people waiting to provide him any help he might need on release and "had received nothing but custodial care while at the hospital."1039 On these facts, the Court held that "a State cannot constitutionally confine without more a nondangerous individual who is capable of surviving safely in freedom by himself or with the help of willing and responsible family members or friends." 1040 The Court specifically declined to decide "whether the State may compulsorily confine a nondangerous, mentally ill individual for the purpose of treatment"1041 - that is, "whether the provision of treatment, standing alone, can ever constitutionally justify involuntary confinement." 1042

$O{ }^{\prime}$ Connor was initially greeted by many observers as a near boundless declaration of freedom for mental patients - as a "renunciation of the past practice of warehousing human beings in conditions which

1037. Note, supra note 1029 , at 1198 n.17.

1038. Donaldson himself was kept in custody against his will for nearly 15 years, 422 U.S. at 564. Data for 1972-1973 from West Virginia revealed that the average stay for involuntary admitees was over 15 years and that more than half these inmates had been held for more than a decade. See State ex rel. Hawks v. Lazaro, 202 S.E.2d 109, 121 (W. Va. 1974). National Institute of Mental Health figures for five states showed that in 1966 and 1968 the median period of confinement ranged between 4.5 and 8.5 years; and in 1969 a majority of the patients in St. Elizabeth's Hospital in Washington, D.C., had been there over five years. Note, supra note 1029, at 1378 n.6.

1039. 422 U.S. at 568-69.

1040. 422 U.S. at 576; see also Gary W. v. Louisiana, 437 F. Supp. 1209, 1222-23 (E.D. La. 1976) (O'Connor's holding applies to mentally retarded or physically handicapped children).

1041. 422 U.S. at 573.

1042. 422 U.S. at 574 n.10. In a separate concurrence, however, Chief Justice Burger did advance the view that a state could not, consistently with due process, "confine an individual thought to need treatment and justify that deprivation of liberty solely by providing some treatment." 422 U.S. at 589. 
were really comparable to Dante's Inferno,"1043 since it was believed that "the vast majority of mentally ill individuals will not engage in dangerous behavior if they are permitted to retain their freedom."1044 These early predictions, however, were not rapidly fulfilled. Surveys in the months immediately following the Court's pronouncement found that very few patients attained their freedom as a direct result of the decision. ${ }^{1045}$ Rather, mental institution officials explained the continued detention of almost all involuntary admittees by correctly pointing out that $O^{\prime}$ Connor "did not rule on the major form of treatment normally given state patients - drugs."1046

These facts notwithstanding, the impact of judicial review - if not of the narrow holding in the $O^{\prime} C o n n o r$ case itself - on the personal liberties of involuntarily confined mental patients has been very significant. Both shortly before and soon after the Supreme Court's decision in $O$ 'Connor, a number of lower federal courts ruled that due process forbids compulsory civil commitment of people unless they are either (1) likely to inflict physical harm on themselves or others, or (2) are not able to survive safely in freedom. ${ }^{1047}$ Under the rationale of these decisions, given credence and support by the Court in $O^{\prime}$ Connor, the mere fact that a person is considered to be mentally ill and in need of treatment cannot constitutionally support involuntary hospitalization. In at least six of the states in which the federal courts had held the involuntary commitment procedures to be invalid, the state legislatures responded by revising their statutes to conform to the judicially announced criteria. ${ }^{1048}$ Further, whereas a 1974 comprehensive survey of state civil commitment laws revealed that "[f]ifteen jurisdictions

1043. Interview with Alan Stone, Chairman for Judicial Action of the American Psychiatry Assn., N.B.C. Today Show (July 8, 1975).

1044. Note, supra note 1029, at 1230. On the day after the decison the New York Times speculated that the Court's edict "appeared likely to force the ultimate release from mental institutions of thousands of the estimated total of 250,000 patients regarded as untreated, harmless and not likely to become community charges." N.Y. Times, June $27,1975, \S 1$, at 1, col. 5 . A week later, Time magazine reported an American Psychiatric Association estimate that $90 \%$ of compulsorily detained mental patients were not sufficiently damaging to themselves or others to require hospitalization. TIME, July 7, 1975, at 44.

1045. See Steinzor, supra note 1031, at 50; Kopolow, A Review of Major Implications of the O'Connor v. Donaldson Decision, 133 AM. J. PsychiatRy 379, 380 (1976).

1046. Steinzor, supra note 1031, at 50.

1047. See, e.g., Stamus v. Leonhardt, 414 F. Supp. 439, 450 (S.D. Iowa 1976); Doremus v. Farrell, 407 F. Supp. 509, 514 (D. Neb. 1975); Lynch v. Baxley, 386 F. Supp. 378, 390 (M.D. Ala. 1974); Bell v. Wayne County Gen. Hosp., 384 F. Supp. 1085, 1102 (E.D. Mich. 1974); Lessard v. Schmidt, 349 F. Supp. 1078, 1084 (E.D. Wis. 1972), vacated, 414 U.S. 473 (1974); Dixon v. Attorney General of Pa., 325 F. Supp. 966, 974 (M.D. Pa. 1971).

1048. See AlA. CODE $\$ 22-52-10$ (enacted 1975); IowA CODE $\$ 229.1$ (amended 1975); 1 Mich. COMP. LAWS ANN. $\$ 330.1401$ (amended 1975); NEB. REV. STAT. \$ 83-1009 (enacted 1976); PA. STAT. ANN. tit. 50, § 7301 (enacted 1976); WIS. STAT. ANN. \$§ 51.01(13)(b), 51.20 (enacted 1975). 
authorize commitment only if the individual is mentally ill and dangerous to himself or others or is unable to care for his physical needs," 1049 within the next five years the lawmaking bodies of more than twenty additional states amended their more loosely drawn statutes to adopt this tighter definition. ${ }^{1050}$ Indeed, a number of courts and legislatures went even further and adopted a "dangerous to self and others" standard as the exclusive test for involuntary commitments. ${ }^{1051}$ The experience in Virginia - where the commissioner of mental health reported that the statute was reformed "in partial anticipation"10s2 of $O^{\prime}$ Connor - is instructive: within a five-year period, the state's institutional population was reduced from 17,000 to 10,000 of whom only 700 were involuntarily confined. ${ }^{1053}$

Thus, the Court's decision in $O^{\prime}$ Connor - along with its progeny and forebearers in other federal courts - has, even in the short run, directly and indirectly advanced the cause of personal freedom. By preserving or restoring the liberty of many mentally ill persons, judicial review has greatly contributed to the prevention of the loss of various legal rights and the suffering of economic, social, and psychological injuries ${ }^{1054}$ which were "often barely distinguishable from the analogous burdens imposed on criminals and may have been even more severe." 1055

1049. Note, supra note 1029 , at 1203.

1050. See, in addition to statutes listed in note 1048 supra, ARK. STAT. ANN. $\S \S 59-1401$, 1428 (enacted 1979); CONN. GEN. STAT. ANN. § 17-179 (amended 1976); DEL. CODE ANN. tit. $\S \S 5001,5002$ (amended 1975); FLA. STAT. ANN. $\S 394.467$ (amended 1979); IND. CODE § 1614-9.1-10 (amended 1975); KaN. STAT. ANN. § 59-2902 (amended 1976); KY. Rev. STAT. ANN. $\S 202 A .080(6)$ (enacted 1976, repealed 1982); Miss. CODE ANN. $\S \$ 41-21-63,75$ (enacted 1975); N.M. Stat. ANN. §43-1-12 (enacted 1977); N.D. CENT. CODE §§ 25-03.1-02, -07 (enacted 1977); OKLA. STAT. ANN. tit. 43A § 3 (amended 1977); S.D. CoMP. LAWS ANN. \$§ 27A-9-18, 1-1 (amended 1976); UTAH Code ANN: § 64-7-36 (amended 1979); VT. STAT. ANN. tit. 18, $\S \S 7101,7617$ (amended 1977); VA. CODE ANN. § 37.1-67.3 (amended 1976); W. VA. CODE ANN. §§ 27-1-12, 27-5-4 (amended 1974).

1051. See, e.g., Suzuki v. Yuen, 617 F.2d 173 (9th Cir. 1980); State v. Krol, 68 N.J. 236, 344 A.2d 289 (1975); In re Scopes, 398 N.Y.S.2d 911 (1977); Mo. ANN. STAT. §§ 632.005, .300, 305 (Vernon enacted 1980); TENN. CODE ANN. § 33-6-104 (amended 1976).

1052. Allerton, $A n$ Administrator Responds, in PAPER Victories and HARD Realities: The IMPLEMENTATION OF the LEgal and Constitutional Rights of the Mentally Disabled 17, 18 (V. Bradley \& G. Clarke eds. 1976).

1053. Id. at 18.

1054. See Note, supra note 1029 , at $1198-1200$.

1055. Note, Overt Dangerous Behavior as a Constitutional Requirement for Involuntary Civil Commitment of the Mentally Ill, 44 U. CHI. L. REV. 562, 563 (1977). 


\section{Procedural Due Process}

\section{Denial of Welfare Benefits}

Prior to the Court's decision in 1970 in Goldberg v. Kelly, ${ }^{1056}$ virtually no state public assistance agencies provided welfare recipients an evidentiary hearing before discontinuing benefits. Although some state and lower federal courts had held that there was a right to a prior hearing, 1057 "the universal practice [was] that the local agency terminates aid by ex parte action and notifies the recipient of the immediately effective termination and of his right to a subsequent hearing if he wishes to contest the termination."1058

Commentators who have studied the impact of the Goldberg ruling have pointed to several factors as undermining its effectiveness. First has been the matter of noncompliance.

[T] he only systematic study that seems to have been made of the compliance of agency practice with post-Goldberg fair hearing regulations found that the New York City public welfare agencies failed to provide a procedurally regular hearing in a significant number of cases . . . [and] there is also evidence of a fairly serious breakdown in the hearing process in other states. ${ }^{1059}$

This may at least in part be attributed to an ambivalent, if not unfavorable, attitude by caseworkers and other welfare staff members toward the importance of due process for their clients. ${ }^{1060}$ Further, despite the enormous rate of error that has been documented in overall welfare administration ${ }^{1061}$ and the great importance of the benefits to affected persons, the number of welfare recipients who seek review hearings is surprisingly small. ${ }^{1062}$ This has been explained on the ground that while the eligibility requirements of the program are very complex, the claimant population has a low educational level and is psychologically reluctant "to fight city hall even when basic entitle-

1056. 397 U.S. 254 (1970).

1057. See Comment, The Constitutional Minimum for the Termination of Welfare Benefits: The Need for and Requirements of a Prior Hearing, $68 \mathrm{MrCH}$. L. REv. 112-13 (1969).

1058. Thorkelson \& Sparer, Do the Present Regulations Governing the Time for Holding Fair Hearings in Public Assistance Violate Constitutional Due Process and the Social Security Act?, 6 WELFARE L. BULL. 8 (1960).

1059. Mashaw, The Management Side of Due Process: Some Theoretical and Litigation Notes on the Assurance of Accuracy, Fairness, and Timeliness in the Adjudication of Social Welfare Claims, 59 CORNELl L. REV. 772, 813-14 (1974).

1060. See Scott, The Reality of Procedural Due Process - A Study of the Implementation of Fair Hearing Requirements by the Welfare Caseworker, 13 WM. \& MARY L. REv. 725 (1972). 1061. See Rubenstein, Procedural Due Process and the Limits of the Adversary System, 11 HARV. C.R.- C.L. L. REv. 48, 68 (1976) (error rate of nearly 40\% nationally).

1062. Mashaw, supra note 1059, at 784 (review sought of approximately $2 \%$ of all appealable denials, terminations or awards challengeable as inadequate). 
ment to benefits is at issue."1063 In addition to the fact that administrators may be deliberately lax in giving beneficiaries effective notice of their procedural rights, there is scant reason to believe that the claimants either adequately comprehend or will skillfully pursue them. Thus, it has been concluded that "the welfare recipient is, realistically speaking, without a remedy that will enable him to protect his rights"; 1064 and "the difficulties of providing meaningful hearings may be much more significant than the Court was called upon to recognize in Goldberg. The question is not so much when recipients can best avail themselves of a hearing, as it is whether the adversary hearing is such a chimerical protection . . . that due process requires more."1065

But to concede that Goldberg falls far short of insuring against erroneous welfare terminations certainly does not mean it has no importance for the liberties of individuals. In the six-month period immediately before the decision's impact was felt, ${ }^{1066}$ statistics indicate that approximately 1,425 recipients of federally aided medical assistance and aid to families with dependent children who had their welfare payments discontinued requested a subsequent hearing to contest termination. ${ }^{1067}$ Although less than ten percent of these claimants

1063. Id. at 812 .

1064. Rubenstein, supra note 1061, at 69.

1065. Mashaw, supra note 1059 , at 815.

1066. Goldberg was decided on March 23, 1970. The six-month period described is JanuaryJune 1970.

1067. This figure $(1,425)$ is obtained through extrapolation from statistics reported in U.S. Natl. Center for Social Statistics, U.S. Dept. of Health, EdUc., and Welfare, Fair Hearings in Public Assistance, JanuarY-June 1970 (Nov. 10, 1971) (NCSS Report E-8) [hereinafter cited as FaIR Hearings, JanuarY-JUNe 1970], and in U.S. NATL. CenTER FOR Social Statistics, U.S. Dept. of Heal,Th, Educ., and Welfare, Falr Hearings in PUbLIC ASSISTANCE, JULY-DECEMBER 1970 (Apr. 5, 1972) (NCSS Report E-8) [hereinafter cited as FAIR HeARINGS, JULY-DeCEMBER 1970 ].

During the period of January-June 1970, there were 19,400 requests for agency hearings. FAIR HEARINGS, JANUARY-JUNE 1970, at 1 . Of the 19,400 requests, 16,700 were disposed of. According to the state agency reports, 2,100 of these 16,700 requests disposed of were made to contest the discontinuance of welfare benefits. Id. at 2. But three states - California, Ohio and South Dakota - did not report figures, $i d$. at 1 , and if they had, the number of hearing requests disposed of concerning discontinuance of benefits would have been about 2,540. FAIR HEARINGS, JULY-DECEMBER 1970, at $3 \&$ n.2. (This figure is derived from statistics showing that the total number of hearing requests increased $51 \%$ from 19,400 to 29,300 between January-June 1970 and July-December 1970 , and that $27.3 \%$ of this increase was attributable to the inclusion of these three states. In order to extrapolate from the July-December figures to the January-July figures, it is necessary to discount the increase (27.3\%) attributable to the inclusion of the three states by the general, national rate of increase (23.7\%). Thus, one may assume that, had these three states been included in the January-June figures, the total number of hearing requests would have increased by $20.8 \%$. Assuming that these hearing requests followed the national pattern, the number of hearing requests disposed of concerning discontinuance of benefits in the January-June 1970 period would have been 2,540 (i.e., 2,100 $\times 120.8 \%$ )).

Fifty-six percent of the 19,400 hearing requests were made under AFDC or medical assistance programs. FAIR HEARINGS, JANUARY-JUNE 1970, at 2. Assuming that this percentage also applies to the number of hearing requests disposed of concerning the discontinuance of 
were represented by counsel, ${ }^{1068}$ over one-quarter succeeded in having their benefits reinstated, ${ }^{1069}$ a ratio confirmed by several earlier studies. ${ }^{1070}$ Had Goldberg's requirement of a prior hearing then been in effect, the great hardship suffered by these persons of having their sustenance cut off for a substantial period of time - a four-month delay between discontinuance and renewal of welfare after the post-termination hearing being typical ${ }^{1071}$ — would have been avoided. 1072

Of perhaps greater significance is that the Goldberg ruling did seemingly encourage more welfare beneficiaries to request hearings when informed that their AFDC or medical assistance aid was to be cancelled. In the six months immediately following the decision, the number of such persons almost doubled to roughly $2,800^{1073}$ although there appeared to be no marked increase in the number of recipients whose benefits were discontinued. ${ }^{1074}$ Nor can this increase be attributed to unentitled recipients making frivolous claims in order to obtain continued payments while the hearing process ran its course. For, again, while under ten percent of the petitioners had lawyers, ${ }^{1075}$ one-quarter demonstrated that the welfare agency's judgment was in-

benefits, one may estimate that approximately 1,425 persons made hearing requests to contest the termination of AFDC or medical assistance benefits (i.e., $56 \%$ of $2,540=1,425$ ).

1068. Of a total of 16,700 hearing requests disposed of concerning welfare claims, 1,500 claimants had lawyers. See FAIR HEARINGS, JANUARY-JUNE 1970, supra note 1067, at table 12.

1069. Of the 16,700 hearing requests disposed of, $4,600(27.5 \%)$ were concluded in the claimant's favor. See id. at tables 6,7.

1070. See Comment, supra note 1057, at 125 n.83 (1969); Note, Due Process and the Right to a Prior Hearing in Welfare Cases, 37 FordhaM L. Rev. 604, 611 n.47 (1969).

1071. See Comment, supra note 1057, at 125 n.83.

1072. Although perhaps among the most dramatic examples, in Goldberg,

an erroneous termination of welfare benefits, coupled with the four-month delay before the error was corrected, resulted in the crowding of thirteen children and two adults into a small apartment where the children lost weight and became ill from lack of food. In the same case, another of the plaintiffs, along with her family "had to go to the hospital for severe diarrhea, apparently brought on by the only meal they had had that day - spoiled chicken and rice donated by a neighbor." In [a companion case], after an erroneous termination of welfare benefits, plaintiffs lacked food, medicine, and other necessities.

Comment, supra note 1057, at 125 (footnote omitted).

1073. In the July-December 1970 period, there were 5,000 reported requests for agency hearings concerning discontinuance of assistance for all federally-aided welfare programs. AFDC constituted $44.2 \%$ and medical assistance $12.1 \%$ of the 29,300 total requests for hearings. Assuming that the AFDC and medical assistance percentages remain constant, 56.3\% (or 2,800) of the 5,000 hearing requests concerning discontinuance of benefits involved recipients under AFDC or medical assistance programs. See FAIR HEARINGS, JULY-DECEMBER 1970, supra note 1067, at 4.

1074. See U.S. Natl. Center for Social Statistics, U.S. Dept. of Health, Educ., and Welfare, Applications, Cases Approved, and Cases Discontinued for Public AsSISTANCE Jan.-March 1970 (NCSS Report A-9), table 5 (143,000); id., Apr.-June 1970, table 5 $(178,000)$; id., July-Sept. 1970, table $5(130,000)$; id., Oct.-Dec. 1970, table $8(147,000)$.

1075. See FAIR HeARINGs, JULY-DecEMBER 1970, supra note 1067, at table 12. 
correct. $^{1076}$ Subsequent data portray a basically similar picture. In the next succeeding half year, the number of hearing requests disposed of, made by persons whose AFDC or medical assistance payments were sought to be discontinued, rose to about $3,400 .{ }^{1077}$ With just slightly more than ten percent represented by counsel, ${ }^{1078}$ over a fifth were successful in resisting termination. ${ }^{1079}$ Five years later, in the first half of 1976 , there were 22,530 hearing requests disposed of involving termination of AFDC and medical assistance benefits. ${ }^{1080}$ Although it is surely quite speculative to attribute this continued increasing trend solely to Goldberg, again with barely over ten percent of the claimants having a lawyer, ${ }^{1081}$ almost twenty-five percent of the claimants prevailed. ${ }^{1082}$

\section{Id. at table 7.}

1077. In the January-June 1971 period, the Department disposed of 34,500 out of 46,500 total hearing requests. Of these $34,500,6,500$ concerned the discontinuance of assistance for all federally-aided welfare programs. U.S. NATL. CENTER FOR SOCIAL STATISTICS, U.S. DEPT. OF health, Educ., and Welfare, Fair Hearings in Public assistance, January-June 1971, at 3, 4 (May 22, 1972) (NCSS Report E-8).

AFDC constituted $44.1 \%$ and medical assistance $8.2 \%$ of the 46,500 total hearing requests. Id. at 4. Assuming these percentages pertaining to total hearing requests also apply to requests disposed of and further apply to requests disposed of concerning the discontinuance of benefits, we may conclude that $52.3 \%$ of the 6,500 hearing requests disposed of concerning discontinuance of benefits specifically concerned AFDC or medical assistance benefits. $(52.3 \% \times 6,500=$ $3,400)$.

1078. Of the 34,500 claimants whose hearing requests were disposed of during January-June $1971,4,300$ (or 12\%) were reported to be represented by counsel. Id. at table 12. (No reports were made in 7,300 cases. Id. If these cases are excluded, the percentage of claimants represented by counsel rises to $16 \%$.) The text assumes that this percentage, pertaining to legal representation of all claimants in the hearing request process, also applies more specifically to legal representation of those claimants contesting the discontinuance of AFDC or medical assistance benefits.

1079. Of the 34,500 claimants whose hearing requests were disposed of during January-June $1971,7,000$ (or 20.3\%) obtained decisions in their favor. Id. at tables 6, 7. The text assumes that this percentage, pertaining to success of all claimants in the hearing request process, also applies more specifically to the success of those claimants contesting the discontinuance of AFDC or medical assistance benefits.

1080. See U.S. NATL. Center for Social Statistics, U.S. DePt. HEalth, Educ., aNd Welfare, Fair Hearings in PUblic Assistance, January-June 1976, at 10 (table 5) (April 1977). All hearing requests were filed under either AFDC (78\%) or medical Assistance (22\%) programs. Id. at 1.

1081. Of the 75,860 claimants whose hearing requests were disposed of during the JanuaryJune 1976 period, 7,967 (or 10.5\%) were reported to be represented by counsel. Id. at 17 (table 12). The type of representation was not specified in 14,236 cases. Id. If these cases are excluded, the percentage represented rises to $13 \%$. The text assumes that this percentage, pertaining to legal representation of all claimants in the hearing request process, also applies more specifically to legal representation of those claimants contesting the discontinuance of AFDC or medical assistance benefits.

1082. Of the 75,860 claimants whose hearing requests were disposed of during January-June $1976,17,586$ (or 23.2\%) obtained decisions in their favor. Id. at 11 (table 6), 12 (table 7). The text assumes that this percentage, pertaining to the success of all claimants, also applies more specifically to the success of those claimants contesting the discontinuance of AFDC or medical assistance benefits. 
It has been suggested that a major benefit of the Justices' edict is that a welfare agency's recognition of its clients' ability to have pay. ments continued during the hearing process deters casually considered terminations. ${ }^{1083}$ Whether or not this is so, the information presented above persuasively implies that the Goldberg decision - though surely augmenting administrative costs (a counterweight that, of course, must be reckoned in virtually all procedural due process cases) ${ }^{1084}$ and causing some extended nonrecoverable payments to ineligible claimants - has appreciably furthered the personal rights of those welfare recipients whose benefits have been sought to be discontinued.

\section{Divorce Filing Fees}

Prior to the Court's decision in Boddie v. Connecticut ${ }^{1085}$ in 1971, holding that due process demands that indigents be permitted to obtain a divorce without payment of court filing fees and costs for service of process, nearly half the states refused to allow impecunious spouses to proceed in forma pauperis in divorce actions. ${ }^{1086}$ Required filing fees ranged from $\$ 5$ to $\$ 60$, the average such charge being about $\$ 30.1087$ In addition, the expense for service of process could run as high as $\$ 150$ when service by publication was used ${ }^{1088}$ — and "since divorce, especially among the indigent, is the type of action where personal or registered mail service is difficult due to the desertion factor, and since service by attorney involves considerable expense, service through publication . . . [was] often the only practical alternative."1089

It is impossible to ascertain the exact number of poor people who have been prevented from dissolving their marriages by these costs, but several widely acknowledged facts strongly suggest that indigents have faced serious difficulties in securing divorce. First, the relationship between low income and marital instability has been confirmed by numerous studies. ${ }^{1090}$ Yet although the bottom economic groups produce the highest separation rates, they also show very low divorce

1083. See Rubenstein, supra note 1061 , at 60 .

1084. See Mathews v. Eldridge, 424 U.S. $319,345,347-49$ (1976).

1085. 401 U.S. 371 (1971).

1086. See Brief of the National Legal Aid and Defender Assn. as Amicus Curiae at $7 \&$ app.

A, Boddie v. Connecticut, 401 U.S. 371 (1971) [hereinafter cited as NLADA Brief].

1087. Id. at app. A.

1088. See Comment, An Indigent's Right to an In Forma Pauperis Proceeding in Pennsylvania Divorce Litigation - Analysis and a Proposal, 16 VILL. L. REV. 282, 289-90 (1970).

1089. Id. at 289.

1090. See, e.g., Goode, Economic Factors and Marital Stability, 16 AM. Soc. Rev. 802 (1951) and studies discussed therein; N.Y. Times, Nov. 13, 1966, § 1, at 39, col. 3. 
rates, ${ }^{1091}$ thus giving inferential support to the intuitive conclusion that many poor people who desire a divorce simply cannot afford one. ${ }^{1092}$

Perhaps even more revealing is that comprehensive surveys of legal aid programs disclose that divorce is very close to the top of the list of problems for which clients seek their services. Thus, for the decade between 1957 and 1966, the National Legal Aid and Defender Association reported that forty-two percent of its nationwide caseload concerned family law matters. ${ }^{1093}$ For the first six months of 1969 , data from more than two-thirds of NLADA offices throughout the country showed that over twenty percent of their new actions were for divorce - in many cities this figure reaching higher than thirty-five percent. ${ }^{1094}$ Nor do these statistics tell the full story. A broad-based survey of 275 legal aid organizations in the 1960's found that only one office in three "has an open policy toward divorce cases; the other offices impose restrictions ranging from a fairly liberal policy to outright exclusion."1095 Thus, in 1966, when an experimental legal aid system in Wisconsin permitted impoverished clients to have any lawyer they wanted for any legal service they needed, sixty-three of the first eighty-six cases were divorce suits. ${ }^{1096}$ Finally, and of greatest importance, even those legal services offices that were receptive to divorce actions usually could not afford payment of the court filing fees and charges for service of process incident to such actions. ${ }^{1097}$ As a consequence, even the data observed does not "reflect the number of indigents who were discouraged from seeking free divorce counsel because of the requirement that they pay these costs." 1098

Because the financial barriers invalidated by Boddie are by no means the only impediments to divorce that confront indigents, ${ }^{1099}$ the Court's ruling has not automatically enabled all poor people who wish to dissolve their marriages to do so. However, it plainly has substantially improved the plight of those many persons whose only previous

1091. See Weeks, Differential Divorce Rates by Occupations, 21 Soc. Forces 334, 336 (1943).

1092. See id.; Comment, supra note 1088, at $284-85$ \& n.6.

1093. See P. STolz, The Legal Needs of the Public: A SuRvey ANAlysis 11-13 (Research Contributions of the American Bar Foundation, No. 4, 1968).

1094. See NLADA Brief, supra note 1086, app. B.

1095. Silverstein, Eligibility for Free Legal Services in Civil Cases, 44 J. URB. L. 549, 581 (1967).

1096. N.Y. Times, Sept. 2, 1966, § 1, at 16, col. 3.

1097. See Comment, supra note 1088, at 287; cf. Brief of Center on Social Welfare Policy and Law et al. as Amici Curiae at 47, Simmons v. West Haven Hous. Auth., 399 U.S. 510 (1970).

1098. Comment, supra note 1088, at 287.

1099. See generally Comment, supra note 1088. 
alternatives were either continuing to live in an unhappy household or separating from their families.

\section{Denial of Child Custody}

In 1972, when the Supreme Court decided Stanley v. Illinois, ${ }_{1100}$ the statutes of at least eleven states ${ }^{1101}$ authorized the permanent removal of an illegitimate child from its father's custody without giving the father either notice or hearing as to his parental fitness. Although some state laws did afford putative fathers such rights, the majority simply failed to address the issue. ${ }^{102}$ The value of the constitutional right set out in Stanley for those fathers who request hearings may be gleaned from the strong tendency of state courts to award parental prerogatives to fathers of illegitimate children who demonstrate their qualifications when the child's mother is dead or unfit. ${ }^{103}$

Further, many states expressly refused to require provision of notice or a hearing to the father concerning his illegitimate child's pending adoption ${ }^{1104}$ - a failure also implictly held violative of due process by the Stanley ruling, ${ }^{1105}$ at least when the father has some significant relationship with the child. ${ }^{1106}$ Responding to this aspect of the Justices' reasoning, "[c]ourts and legislatures in a number of states . . . felt constrained to require notice of adoption even to unknown fathers by way of publication," 1107 and the Uniform Parentage Act (adopted in eight states as of 1980)1108 "not only requires the court to inquire of the mother concerning the identity of the natural father . . .

1100. 405 U.S. 645 (1972).

1101. Florida, Georgia, Illinois, Minnesota, Mississippi, Missouri, North Dakota, South Dakota, Tennessee, Wisconsin and Wyoming. Brief for Petitioner at 69-70, Stanley v. Illinois, 405 U.S. 645 (1972); see also Note, Father of an Illegitimate Child - His Right to be Heard, 50 MINN. L. REv. 1071, 1075-76 (1966) [hereinafter cited as Note, Right to be Heard]; Note, Stanley v. Illinois: Constitutional Rights of a Putative Father, 41 UMKC L. REv. 334, 351-52 (1972); Note, Domestic Relations - Putative Father's Rights to Custody of His Child, 1971 WIS. L. REV. $1262,1265$.

1102. See Note, Right to be Heard, supra note 1101, at 1075-76.

1103. See id. at 1073-74; Comment, The Emerging Constitutional Protection of the Putative Father's Parental Rights, 70 MICH. L. REv. 1581, 1582-83 (1972).

1104. See Comment, supra note 1102, at 1584; Note, The "Strange Boundaries" of Stanley: Providing Notice of Adoption to the Unknown Putative Father, 59 VA. L. REv. 517 n.4 (1973).

1105. See Quilloin v. Walcott, 434 U.S. 246, 253-54 (1978); Miller v. Miller, 504 F.2d 1067 (9th Cir. 1974); In re M., 132 Vt. 410, 413-14, 321 A.2d 19, 21-22 (1974).

1106. Lehr v. Robertson, 103 S. Ct. 2985 (1983).

1107. Bodenheimer, New Trends and Requirements in Adoption Law and Proposals for Legislative Change, 49 S. CAL. L. Rev. 10, 63 (1975); see also HandbooK OF THE NaTl. Conf. OF Commrs. ON UNIForm STATE LAws 355-56 (1973); Note, Protecting the Putative Father's Rights After Stanley v. Illinois: Problems in Implementation, 13 J. FAM. L. 115, 126-32 (197374).

1108. HandBook of THE NaTL. CONF. of COMmRs. ON UNIForm State Laws 455-58 (1980). 
but permits the court to compel the mother's testimony on this point."1109 In this regard, some notion of Stanley's potential consequences for individual liberty is revealed by the fact that the number of illegitimate births in the United States approached 600,000 annually by the end of the 1970 's, ${ }^{110}$ and that perhaps as many as one-third of such children are subsequently adopted.1111 Moreover, whereas prior to Stanley a substantial majority of states denied a natural father visitation rights over the mother's objection, 1112 the Uniform Parentage Act has since provided mechanisms for his obtaining such privileges. ${ }^{1113}$

Finally, although the Court has since declined to extend Stanley's rationale to require the putative father's consent before his illegitimate child may be adopted, ${ }^{114}$ a substantial number of states responded to Stanley by legislating such a right ${ }^{1115}$ - a voluntary expansion of the Court's protection of personal liberty likely to continue despite the Court's subsequent refusal to mandate it.

\section{Suspension from Public Schools}

In 1975 , statutes in virtually all states specifically or impliedly authorized suspension of public school pupils for as long as ten days without requiring that the pupil be given prior notice of the charged misconduct or an opportunity to explain his side of the story. ${ }^{1116}$ Statistics from school districts in such cities as Akron, Charlotte, Cincinnati, Cleveland, Dallas, Houston, Little Rock, Memphis, Miami, New Orleans and New York varied somewhat, but it showed that the number of children affected each year was enormous. ${ }^{1117}$ One survey estimated that five percent of all secondary school pupils were sus-

1109. Barron, Notice to the Unwed Father and Termination of Parental Rights: Implementing Stanley v. Illinois, 9 FAM. L.Q. 527, 537 (1975).

1110. Bureau of the Census, U.S. DePt. of Commerce, Statistical ABstract of THE UNITED STATES: 1982-83, at 66 (1982).

1111. See Comment, supra note 1102 , at 1584.

1112. Tabler, Parental Rights in the Illegitimate Child: Some Legitimate Complaints on Behalf of the Unwed Father, 11 J. FAM. L. 231 (1971).

1113. See Note, The Rights of Fathers of Non-Marital Children to Custody, Visitation and to Consent to Adoption, 12 U.C.D. L. REV. 412, 437 (1979).

1114. See Quilloin v. Walcott, 434 U.S. 246 (1978).

1115. See Comment, The Unwed Father's Rights in Adoption Proceedings: A Case Study and Legislative Critique, 40 ALB. L. REv. 543, 565 n.144 (1976).

1116. See Zimring \& Solomon, The Principle of the Thing: Goss v. Lopez, Students' Rights and Litigation in the Interest of Children, in IN THE INTEREST OF CHILDREN: ADVOCACY, LAW REFORM AND PUBLIC POLICY part VI (R. Mnookin ed. forthcoming 1985); see, eg., Mo. ANN. STAT. $\S 167.171$ (Vernon 1965) (amended 1973 to provide for notice of charges and an opportunity to explain conduct); $c f$. E. Bolmeier, Legality of Student Disciplinary Practice 97-98 (1976).

1117. See Goss v. Lopez, 419 U.S. 565, 592 n.10 (1975) (Powell, J., dissenting); Flygare, 
pended annually, ${ }^{1118}$ a figure generally confirmed by national statistics for the 1976-1977 school year. ${ }^{119}$ Another study of junior and senior high school students in Arkansas, Maryland, New Jersey, Ohio and South Carolina reported that about ten percent were suspended one or more times during the 1972-1973 school year. ${ }^{1120}$ If this five-state sample figure were projected nationwide, it would amount to over two million suspensions a year. ${ }^{1121}$ The evidence further revealed that the suspensions fell disproportionately on members of racial minorities ${ }^{1122}$ - civil rights organizations claiming that "[i]n most localities a Black is at least two or three times more likely than a White to be suspended from public school."1123 Persons in black communities viewed "the suspension of minority students as the rearguard attempt of school officials to perpetuate dual school systems."1124

The harmful effects of suspensions on school children are necessarily more difficult to document, but it is fair to assume that they may well prejudice future college and employment applications. Although other adverse consequences are yet more conjectural, professional observers of children and education believe that a pupil's suspension from school may damage his self-image and his status with teachers and peers, thus impairing his educational progress and his overall mental and emotional growth. ${ }^{1125}$

The data concerning the degree to which the Court's 1975 decision

Short-Term Student Suspensions and the Requirements of Due Process, 3 J. L. \& EDuc. 529, 530. 31 (1974), and authorities cited therein.

1118. Flygare, supra note 1117 , at 531.

1119. OFFICE FOR CIVIL. Rights, U.S. DEPT. OF HEALTh, EduC., AND WELFARE, DireCTORY OF ElEMENTARY AND SECONDARY SCHOOL DISTRICTS, AND SCHOOLS IN SELECTED SCHOOL DISTRICTS: SCHOOL YEAR 1976-1977, at IX, XIII (1979) (1,629,000 suspensions; $43,714,000$ total enrollment); see also Kaeser, Suspensions in School Discipline, 11 EDUc. \& URB. SocY. 465,469 (1979) (one study estimated that $4.2 \%$ of all students were suspended during 1972-1973 school year).

1120. Brief for Children's Defense Fund of the Washington Reasearch Project, Inc. et al. as Amici Curiae at 22, 23, Goss v. Lopez, 419 U.S. 565 (1975) [hereinafter cited as Brief for Children's Defense Fund].

1121. See Flygare, supra note 1117, at 531 (a $5 \%$ rate projected nationwide would affect one million students).

1122. See Brief for Children's Defense Fund, supra note 1120, at 21-23; Brief for NAACP and the Southern Christian Leadership Conference as Amici Curiae at 5, Goss v. Lopez, 419 U.S. 565 (1975) [hereinafter cited as Brief for NAACP]; Demarest \& Jordan, Hawkins v. Coleman: Discriminatory Suspensions and the Effect of Institutional Racism on School Discipline, 20 INEQUALITY IN EDUC. 25 (1975); Kaeser, supra note 1119, at 471.

1123. Brief for NAACP, supra note 1122 , at 3-4.

1124. Wilkinson, Goss v. Lopez: The Supreme Court as School Superintendent, 1975 SuP. CT. REV. 25, 31.

1125. See Buss, Procedural Due Process for School Discipline: Probing the Constitutional Outline, 119 U. PA. L. REv. 545, 576 (1971). See generally J. HolT, How ChILdREN FAIL 1 (1964). 
in Goss v. Lopez ${ }^{1126}$ - imposing minimal procedural due process requirements for public school suspensions - has remedied these conditions or otherwise advanced personal liberty is relatively thin. ${ }^{1127}$ Although state statutes and administrative regulations have been amended to conform to the Court's ruling, ${ }^{1128}$ related prior experience raises the possibility of a wide gap between formal rules and actual practice:

A study of New York City's school officials' compliance with disciplinary hearing requirements, voluntarily adopted by the Board of Education, did not find a single instance in which the Board's regulations had been fully observed . . . [and] an analysis of South Carolina school districts' practice concluded that few had established hearing procedures, despite a state statute obliging them to do so. ${ }^{1129}$

Thus, it is not unfair to speculate that "Goss may go ignored, or few students may demand hearings, or the hearing right may be so truncated as to be rendered practically meaningless." 1130

The sparse information that has been gathered since the Court's edict, however, is somewhat more encouraging. Reports from Indiana and Mississippi disclose that even before Goss many school principals already afforded at least those rudimentary procedural safeguards mandated by the Court. ${ }^{131}$ In the words of one principal, "Goss only affirms what principals with common sense should have been doing all along." 1132 This argument directly mitigates the fears of the Goss dissenters that "few rulings would interfere more extensively in the daily functioning of schools than subjecting routine discipline to the formalities and judicial oversight of due process," 1133 and that "if hearings

1126. 419 U.S. 565 (1975).

1127. See Zimring \& Solomon, supra note 1116; Timar, The Aftermath of Goss in the Federal Courts, 9 NOLPE SCH. L.J. 123, 126 (1981).

1128. See, e.g., Cal. Educ. Code $\$ \S 48900-921$ (West Supp. 1984); Ill. ANN. STat. Ch. 122, § 10-22.6 (Smith-Hurd Supp. 1984-85); OHIo REV. CODE ANN. § 3313.66 (Baldwin 1983); PA. Stat. ANN. tit. 24 § 13-1318 (Purdon Supp. 1984-85); Wyo. STAt. ANN. § 21-4-305 (1977); see also Case Note, Notice and Hearing Required for Short Term Suspensions from High School: Goss v. Lopez, 10 LAND \& WATER L. REv. 616 (1975) (regulation of Wyoming State Dept. of Education). See generally Zimring \& Solomon, supra note 1116; Hazard, Court Intervention in Pupil Discipline, 23 Am. Behav. Scientist 169, 188-93 (1979).

1129. Kirp, Proceduralism and Bureaucracy: Due Process in the School Setting, 28 STAN. L. REV. 841, 853 (1976).

1130. Id. at 860 .

1131. See Draba, Hertz, \& Christoff, The Impact of the Goss Decision: A State Survey, 52 VIEwPoINTs 1, 7-8 (No. 5, 1976) [hereinafter cited as Draba]; Comment, Student Rights and Due Process: Procedural Requirements of Goss v. Lopez, 46 Miss. L.J. 1041, 1069 (1975).

1132. Draba, supra note 1131, at 16; see also Letwin, Perspectives on the Post-Civil War Amendments: After Goss v. Lopez: Student Status as Suspect Classification?, 29 STAN. L. REv. $627,653 \mathrm{n} .101$ (1977) ("due process has not heralded a blizzard of formal campus hearings" at UCLA).

1133. 419 U.S. at 591 (Powell, J., dissenting). 
were required for a substantial percentage of short-term suspensions, school authorities would have time to do little else."1134 More importantly, it provides a strong reason to feel that the decision will not go unheeded, a belief supported by a review of the adjudications since Goss revealing that the Justices' mandate has been quite scrupulously observed. ${ }^{1135}$ Moreover, the view that the Goss procedures will reduce mistaken suspensions and promote a more judicious use of this form of discipline is confirmed by the responses of school principals in the Indiana survey. One group suggested that they would have to "tightenup" their procedures in terms of "better record keeping" and see that "more care [is] exercised in explaining suspensions."1136 It has been observed that Goss may also provide a school administrator who is sympathetic to the pupils' needs, yet 'beleaguered by teachers and teacher unions, an excuse to be fair, to remind teachers that while he trusts and supports them, he is constitutionally obligated at least to listen to the student's side."1137 Other principals indicated that they would tend to substitute other forms of discipline for suspension. ${ }^{1138}$ Thus, teachers may admonish a misbehaving pupil, scold him, isolate him by seating him at the back of the class, reduce his grades, or even administer corporal punishment (for which the Court seemingly has held the Goss requisites inapplicable). ${ }^{139}$ All of these actions may arouse peer group pressure - "a tried and true method of obtaining conformity with rules"1140 — but, although it is by no means plainly demonstrable, none would appear to carry as great a stigma as suspension or as serious potential consequences for educational and personal development."141 "A teacher may also seek aid from counselors and parents, arranging a conference to discuss the student's problems. On occasion, these measures have lead to more formal procedures, but often the matter will end where it began — in the classroom."1142

Much more empirical work remains to be done on the multifaceted

1134. 419 U.S. at 592 (Powell, J., dissenting).

1135. See Timar, supra note 1127.

1136. Draba, supra note 1131 , at 17.

1137. Wilkinson, supra note 1124 , at 67 .

1138. Draba, supra note 1131, at 17. But cf. Zimring \& Solomon, supra note 1116.

1139. See Ingraham v. Wright, 430 U.S. 651 (1977).

1140. Yudof, Legalization of Dispute Resolution, Distrust of Authority and Organizational Theory: Implementing Due Process for Students in the Public Schools, 1981 WIS. L. REv. 891, 911.

1141. When public education is "viewed as a public family, then 'suspension, unlike discipline within the school, is not the equivalent of a parental spanking or an order for junior to go to his room. The analogy is to throwing a child out of the house, albeit for a limited period of time." " Zimring \& Solomon, supra note 1116.

1142. Yudof, supra note 1140 . 
potential impact of Goss, including its impetus for rules establishing fairer procedures for longer term separations of students from schools. ${ }^{143}$ However, there is at least some evidence and promise that, in addition to avoiding an unknown number of unjust suspensions, the decision will enhance the appearance of evenhanded punishment and may improve communication between school officials and suspected student troublemakers, thereby achieving the ancillary benefits of increasing student respect for the disciplinary process and relieving certain racial tensions in the schools. ${ }^{1144}$ Finally, even if the Justices' ruling turns out to have been primarily symbolic, "the tangible but nonetheless important role of the competition between authority and autonomy symbols and the way in which this conflict was resolved may be the enduring legacy of Goss v. Lopez." 1145

\section{Termination of Utility Service}

As of the mid-1970's, more than 2200 electric utilities in the country, accounting for $13.5 \%$ of the total customers and $16.4 \%$ of the total kilowatt hours sold, were publicly owned. In addition, local governments provided the source of most water used by Americans and some municipalities also operated gas supply systems which generated $\$ 624$ million in annual revenues in 1977. ${ }^{1146}$ Although the policy of discontinuing service without notice for nonpayment was not universal, 1147 this "most troublesome and controversial billing practice"1148 was recognized as 'municipal utility managers' most effective means"1149 of collection. In the City of Memphis alone, statistics from 1973-1974 showed an average of nearly 2000 "so-called delinquent cutoffs" each month. ${ }^{1150}$ The seriousness of this course of action is most sharply illustrated by 1978 reports from New York that "[i]n the last four years there have been four deaths in the state blamed on

1143. See Zimring \& Solomon, supra note 1116.

1144. See Wilkinson, supra note 1124 , at 32.

1145. Zimring \& Solomon, supra note 1116.

1146. 4 GOVERNMENTAL. FinANCES, FinANCES OF Municipalities and Township GovERNMENTS 5 (No. 4), in 1977 CENSUS OF GOVERNMENTS (Bureau of the Census, U.S. Dept. of Commerce 1979); A. Finder, The States and Electric Utility Regulation 4 (Council of State Govts. 1977).

1147. See A. FINDER, supra note 1146, at 64; Duffy, Service Denial for Nonpayment Through the Years, PUB. UTIL. ForT., Oct. 26, 1978, at 4, 4.

1148. A. FINDER, supra note 1146, at 64.

1149. 1978 Report of Committee on Municipal Water Problems, 42A NIMLO MUN. L. REv. 235, 254 (1979).

1150. Memphis Light, Gas \& Water Div. v. Craft, 436 U.S. 1, 23 n.1 (1978) (Stevens, J., dissenting). 
power cutoffs during the winter."11s1

The Court's decision in Memphis Light, Gas \& Water Division v. Craft ${ }^{1152}$ - holding that due process requires notice and at least "some kind of hearing"1153 prior to termination of services by publicly owned utilities ${ }^{154}$ - will not, of course, assure the continued provision of these "necessit[ies] of modern life"115s irrespective of ability to pay. But given the substantial number of erroneous deprivations, especially "by an impersonal bureaucracy held together by computers" 1156 - one survey showing that " $16 \%$ of the complaints investigated by [the] New York Public Service Commission resulted in adjustments in favor of the customer"1157 - the Justices' ruling promises to significantly alleviate real threats to convenience, health, safety and life itself.

\section{Adjudication of Paternity}

There are many reasons why "[a]n adjudication of paternity may profoundly affect a person's life."1158 The resulting support obligation, almost universally enforceable by the sanction of imprisonment, ${ }^{1159}$ may not be avoided by mere lack of income and liquid assets. ${ }^{1160}$ Even if a finding of liability results in no actual payment (and there is much evidence that it often does not), ${ }^{1161}$ there is the real likelihood that a judicial conclusion of paternity "may disrupt an es-

1151. Duffy, supra note 1147 , at 5 .

1152. 436 U.S. 1 (1978).

1153. 436 U.S. at 16.

1154. But cf. Jackson v. Metropolitan Edison Co., 419 U.S. 345 (1974) (due process requirements not applicable to privately owned utility).

1155. 436 U.S. at 18.

1156. Bronson v. Consolidated Edison Co., 350 F. Supp. 443, 448 (S.D.N.Y. 1972).

1157. 436 U.S. at 18 n.21.

1158. Salas v. Cortez, 24 Cal. 3d 22, 28, 593 P.2d 226, 230, 154 Cal. Rptr. 529, 533, cert. denied, 444 U.S. 900 (1979).

1159. E.g., Cal. Civ. Code $\S 7012$ (West 1982); Cal. Penal Code $\S 270$ (West 1982); ConN. Gen. Stat. ANN. §§ 46b-171, 42b-215, 53-304 (West Supp. 1984); W. VA. Code § 48-81 (1980). See also H. KraUSe, Illegitimacy: LaW and Social Policy 153 (1971). But see Walker v. Stokes, 54 Ohio App. 2d 119, 375 N.E.2d 1258 (1977).

1160. The support duty may be satisfied from life and health insurance, survivor's and wrongful death benefits, and workers' compensation, see Krause, Child Welfare Parental Responsibility and the State, 6 FAM. L.Q. 377, 388-89 (1972), and is more easily secured by garnishment than most ordinary civil judgments. See, e.g., 15 U.S.C. $\$ 1673(b)(1)$ (1982); INT. REv. CoDE $\S 6103(1)(6)(1984)$. Since child support responsibility is not dischargeable in bankruptcy, see 11 U.S.C. § 35(a)(7) (1982), it applies to income generated and property acquired during all of the youth's minority. Indeed, "the consequences of a paternity judgment . . . [even] reach beyond the grave - the child will succeed to the estate of the father if he dies intestate . . . or share in the father's estate by will unless affirmatively excluded." Salas v. Cortez, 24 Cal. 3d 22, 28 n.3, 593 P.2d 226, 230, 54 Cal. Rptr. 529, 533 n.3.

1161. See D. Chambers, Making Fathers Pay 77-78 (1979). 
tablished family and damage reputations." 1162

Despite these potentially disastrous consequences, which argue for care in application of the cause of action, paternity suits - historically designed to relieve welfare authorities of the burden of supporting illegitimate offspring ${ }^{1163}$ - have been widely characterized as being unfair to the defendant. For example, such actions have been called "the widest area of legal 'shakedown' that is known to exist."1164 Unwed mothers obviously have a powerful economic incentive to establish paternity, an incentive which is generally reinforced by the state's provision of special assistance by the district attorney ${ }^{1165}$ and subsidized by the federal government.1166 Since 1975, the Social Security Act has required states, as a condition of receiving AFDC funds, to undertake to identify the father of a dependent child born out of wedlock and to impose on him a duty of support. ${ }^{1167}$ States, in response, have refused to provide welfare assistance to the mother of an illegitimate child unless she discloses the name of the putative father and cooperates in establishing his paternity. ${ }^{1168}$

There are various reasons why the mother may either erroneously identify the father of her child or deliberately name an innocent man. She may not really know which of several men is actually the father; she may wish to shield the true father from the consequences of his action or to protect herself from retribution as a result of naming him; ${ }^{1169}$ or economic necessity may lead her simply to supply a plausible candidate in order to obtain direct support or welfare benefits. The results of a six-year study by lie detector experts of over 300 disputed paternity suits in Chicago in which the mothers took polygraph tests after the trial showed that, in nearly half of the cases, the complainant was "lying when she denied having interçourse with anyone else but the defendant during the conception period. In the great majority of cases the lying mother confessed to the lie-detector examiner that she

1162. Salas v. Cortez, 24 Cal. 3d 22, 28; 593 P.2d 226, 230, 54 Cal. Rptr. 529, 533.

1163. See Krause, Scientific Evidence and the Ascertainment of Paternity, 5 FAM. L.Q. 252, 252-53 (1971).

1164. Schatkin, Should Paternity Cases Be Tried in a Civil or Criminal Court?, 1 CRIM. L. REV. (N.Y.) 18, 24 (1954).

1165. See H. KRAUSE, supra note 1159, at 115-16. An example of such a provision is CAL. WELF. \& INST. CODE $\S 11350.1$.

1166. See 42 U.S.C. $\S 654(6)(A)$,(B) (1982) (Deering 1979).

1167. See 42 U.S.C. § 654(4) (1982); 45 C.F.R. § 232.12(a)(2)-(4) (1983).

1168. See, e.g., CAL. WeLF. \& INST. CODE $§ 11477$ (b) (West 1980 \& Supp. 1984); CoNN. GEN. STAT. ANN. § 46b-169 (West Supp. 1984).

1169. See Poulin, Illegitimacy and Family Privacy: A Note on Maternal Cooperation in Paternity Suits, 70 Nw. U. L. REV. 910, 923-24 (1976). 
had lied in court." 1170 Moreover, as Justice Stanley Mosk of the California Supreme Court observed, "[i]n the emotional atmosphere generated in the courtroom by the spectacle of the unwed mother and the unwanted baby, it will often not be enough for an unjustly accused man to simply deny paternity, especially when . . . he concededly has had sexual intercourse with the mother at an earlier date."1171 This emotional atmosphere helps to explain why, in paternity suits, "accusation is often tantamount to conviction"1172 and defendants not uncommonly are reported in surveys as losing as many as ninety-five percent of the cases. ${ }^{1173}$

Fortunately, the recent development of extremely sophisticated blood grouping tests - which conclusively negate paternity for ninety-three percent of falsely accused whites and ninety-one percent of falsely accused blacks ${ }^{1174}$ - has provided a solution to much of the problem. Even before the latest advances in genetic testing, scientific studies demonstrated the tendency toward gross inaccuracy in paternity charges. Blood samples in 1,000 disputed paternity actions in a New York City survey disclosed that nearly forty percent of the accused fathers were innocent. ${ }^{1175}$ Indeed, it has been found in another study that almost twenty percent of the men who actually admitted paternity were not the fathers of the children they acknowledged.1176 Of those cases that were finally adjudicated, it has been reliably estimated that more than one in seven defendants were erroneously held liable. ${ }^{1177}$

1170. Arthur \& Reid, Utilizing the Lie Detector Technique to Determine the Truth in Disputed Paternity Cases, 45 J. Crim. L., Criminology \& Police SCI. 213, 217 (1954). This evidence may, of course, be discounted depending on the faith one places in polygraph results.

1171. Huntingdon v. Crowley, 64 Cal. 2d 647, 651, 414 P.2d 382, 386, 51 Cal. Rptr. 254, 258 (1966).

1172. Krause, supra note 1163 , at 255.

1173. See Glazer, Blood Grouping Tests in the Proof of Non-Paternity, Mich. ST. B. J. Vol. 33, No. 1, at 12, 17 (1954); Sussman, Blood Grouping Tests - A Review of 1000 Cases of Disputed Paternity, 40 AM. J. Clinical Pathology 38 (1963).

1174. Krause, Joint AMA-ABA Guidelines: Present Status of Serologic Testing in Problems of Disputed Parentage, 10 FAM. L.Q. 247 (1976). For discussion of the possible use of such tests actually to prove, rather than merely disprove, paternity, see Terasaki, Resolution by HLA Testing of 1000 Paternity Cases Not Excluded by ABO Testing, 16 J. FAM. L. 543 (1977-78); Note, Paternity Testing with the Human Leukocyte Antigen System: A Medicolegal Breakthrough, 20 Santa Clara L. Rev. 511 (1980).

1175. Sussman, supra note 1173 , at 38,40 . A study of 6665 paternity suits in several European countries concluded that "half of the defendants in these cases were falsely accused." A. WIENER, BLOOD GROUPS AND TRANSFUSION 383 (3d ed. 1943).

1176. Sussman \& Schatkin, Blood Grouping Tests in Undisputed Paternity Proceedings, 164 J. A.M.A. 249, 250 (1957).

1177. Sussman, supra note 1173 , at 41 . A similar study led to the conclusion that "of the bastardy cases coming to trial in . . . [Wayne County, Michigan], the defendant is wrongfully found guilty in over $25 \%$ of the cases." Glazer, supra note 1173 , at 17. 
In Little v. Streater, ${ }^{1178}$ the Court held that due process required Connecticut to pay the expense of blood grouping tests for indigent defendants in paternity suits - a cost of $\$ 460$ in 1980.1179 Although the Court limited its ruling to the "specific circumstances"1180 surrounding paternity proceedings in Connecticut, it is unlikely that the factors highlighted by the Court can distinguish Connecticut from other jurisdictions. First, the "quasi-criminal overtones"1181 associated with Connecticut's paternity action - e.g., the defendant's being subject to imprisonment for noncompliance with a support order ${ }^{182}-$ are not meaningfully different from those that exist in other states. ${ }^{1183}$ Second, Connecticut's extensive involvement in paternity suits - its requirement that the mother identify and sue the father as a condition for receipt of welfare, its legal and financial assistance in her prosecution of the case, and its economic interest in the outcome - is substantially similar to the general practice ${ }^{1184}$ and would seem to have been emphasized by the Court more to differentiate the claim before it from the contention "that Connecticut has a constitutional obligation to fund blood tests for an indigent's defense in ordinary civil litigation between private parties"118s than to narrow the holding to the specific Connecticut case. It is true that the third factor discussed by the Court - the Connecticut rule that the defendant's testimony denying fatherhood is itself insufficient to rebut the plaintiff's prima facie case which is "made out by constancy in her accusation" 1186 - appears to be limited to that state. However, the special circumstances and extraordinary conviction rates in paternity actions referred to above strongly indicate that Connecticut's formally stated presumption in fact operates generally. This inference is confirmed by an Illinois Family Study Commission which reported that "[t]estimony from the sitting judiciary hearing paternity cases revealed . . . that the evidence in most cases consists of an accusation by the woman and a denial by the defendant. Under such circumstances, the judges feel constrained to enter a finding of paternity." 1187

1178. 452 U.S. 1 (1981).

1179. 452 U.S. at 14 n.10.

1180. 452 U.S. at $16,17$.

1181. 452 U.S. at 10.

1182. 452 U.S. at 10.

1183. See note 1159 supra and accompanying text.

1184. See notes $1165-68$ supra and accompanying text.

1185. 452 U.S. at $9,10$.

1186. Mosher v. Bennett, 108 Conn. 671, 674, 144 A. 297, 298 (1929).

1187. Illinois Family Study Commission on Marriage, Divorce and Parental RESPONSIBILITY, REPORT AND RECOMMENDATIONS 55 (1969). 
Since only a handful of jurisdictions had a clearly articulated position on the issue in Little, the full scope of the impact of the Justices' ruling cannot be precisely measured. On the one hand, only Connecticut and North Carolina explicitly required all those accused in paternity suits, irrespective of means, to bear the cost of their blood tests. ${ }^{1188}$ On the other hand, nearly three-quarters of the jurisdictions either expressly allowed the expense to be charged to some public agency or gave the courts some degree of discretion to do so. ${ }^{1189}$ In at least some of these states, however, it is plain that the authorization afforded no guarantee to indigent defendants. ${ }^{1190}$ In a few states, either lower court decisions, attorney general opinions, or administrative policies provided for payment, but about one-fifth of the jurisdictions had no relevant statutory judicial or administrative pronouncement. ${ }^{1191}$ Most significantly, in the three states whose highest courts had presaged the edict in Little, ${ }^{1192}$ explicit reliance was placed on the Court's earlier reasoning in Griffin $v_{\text {. Illinois, }}{ }^{1193}$ where it held that states must afford indigent criminal defendants the means for adequate and effective appellate review. ${ }^{1194}$ This underlines the value of the Justices' efforts to protect indigent paternity defendants. ${ }^{1195}$

\section{Free Speech, Press and Association}

\section{Commercial Advertising}

Two Supreme Court rulings in the mid-1970's - Virginia State Board of Pharmacy v. Virginia Citizens Consumer Council ${ }^{1196}$ and

1188. 452 U.S. at $15 \mathrm{n} .11$.

1189. For a detailed listing, see Brief for Appellant at 16-18 n.17, Little v. Streater, 452 U.S. 1 (1981) [hereinafter cited as Brief for Appellant].

1190. See, e.g., Bigsby v. Bates, 59 Ohio Misc. 51, 391 N.E.2d 1384 (1978) (no free blood tests). See also KAN. STAT. ANN. § 23-131, 23-132 (1981) (cost may be taxed to losing party).

1191. Brief for Appellant, supra note 1189 , at n.17.

1192. Franklin v. District Court, 194 Colo. 189, 571 P.2d 1072 (1977); Commonwealth v. Possehl, 355 Mass. 575, 246 N.E.2d 667 (1969); State ex rel. Graves v. Daugherty, 266 S.E.2d 142 (W. Va. 1980).

1193. 351 U.S. 12 (1956).

1194. 351 U.S. at $18,20$.

1195. The possible prejudice that may occur to an indigent accused of fatherhood was dramatically illustrated in the case of Salas v. Cortez, 24 Cal. 3d 22, 593 P.2d 226, 154 Cal. Rptr. 529 , cert. denied, 444 U.S. 900 (1979). The district attorney first "brought a suit on behalf of the same minor child against another man. That man secured counsel, and a request for temporary support was denied for lack of evidence. Suit was then filed against Mr. Castellanos, alleging that he was the father of the child. Mr. Castellanos did not attend the hearing on temporary support and was found to be the child's father partially on the basis of testimony given at that hearing." $24 \mathrm{Cal}$. 3d at 31 n.8, 593 P.2d at 232, 154 Cal. Rptr. at 535 (emphasis in original). Clearly, the Court's holding in Little might have aided Mr. Castellanos.

1196. 425 U.S. 748 (1976). 
Bates v. State Bar of Arizona1197 - afforded some constitutional protection to commercial advertising by druggists, lawyers and (by plain implication) members of other professions. It is difficult to estimate the extent to which the decisions were themselves critical in forging the substantial consequences that have resulted, because before the first of the Justices' major rulings in 1976, both the Justice Department and the Federal Trade Commission had launched challenges under the federal antitrust laws against restrictions imposed by state statutes and professional organization canons respecting advertising by attorneys, ${ }^{1198}$ dentists, ${ }^{1199}$ physicians, ${ }^{1200}$ druggists, ${ }^{1201}$ and suppliers of ophthalmic goods and services. ${ }^{1202}$ Indeed, just five weeks after the Court's pronouncement in Virginia Pharmacy, the FTC postponed indefinitely its proposed rules governing disclosure of retail prices for prescription drugs. ${ }^{1203}$ However, given the existing "state action" doctrine under the antitrust laws, which exempted regulations with which the state was intimately involved from the reach of antitrust actions, ${ }^{1204}$ the Justices' interpretation was necessary to invalidate those advertising restrictions that were closely regulated by state agencies $^{1205}$ and to eliminate the theoretical possibility that "private" professional codes held to be contrary to the antitrust laws could be resuscitated either by state legislative or administrative rule or through broader congressional grant of immunity from antitrust coverage.

The obstacles to professionally related advertising were widespread prior to the Court's constitutionally grounded intervention. Approximately two-thirds of the states posed significant barriers to disclosure of prescription drug prices in the print or broadcast media, ${ }^{1206}$ thus greatly diminishing consumer access to information about the extreme

1197. 433 U.S. 350 (1977).

1198. See Devine, Lawyer Advertising and the Kutak Commission: A Refreshing Return to the Past, 18 WAKE FOREST L. REv. 503, 514 (1982); Justice Department Charges Code Advertising Provisions Violate Federal Antitrust Laws, 62 A.B.A. J. 979 (1976); see also Goldfarb v. Virginia State Bar, 421 U.S. 773 (1975).

1199. See Swerdlow \& Staples, Dentists' Views on Advertising in Their Profession, AKRON Bus. \& ECON. Rev. Summer 1980, at 33, 34.

1200. See In re American Medical Association, 94 F.T.C. 701 (1979).

1201. See United States v. American Pharmaceutical Assn., No. G75-558-CA5 (W.D. Mich. filed Nov. 24, 1975); 40 Fed. Reg. 24031 (1976).

1202. See 41 Fed. Reg. 2,399 (1976).

1203. See 41 Fed. Reg. 27,391 (1976).

1204. See Parker v. Brown, 317 U.S. 341 (1943); Cantor v. Detroit Edison Co., 428 U.S. 579 (1976).

1205. Bates, 433 U.S. at 359-63.

1206. Staff Report to FTC, Prescription Drug Price Disclosures 34 (1975). 
variances in drug costs documented throughout the nation 1207 and markedly increasing the prices paid. ${ }^{1208}$ Virtually all lawyers were prohibited by the ABA Code of Professional Responsibility from making "any form of public communication . . . calculated to attract lay clients."1209 Although the American Medical Association condoned "tasteful" ads by doctors, ${ }^{1210}$ this authorization was applied to ban any mention of price, an announcement of extended office hours, and communication of most relevant data about health maintenance organizations and prepaid medical care plans. ${ }^{1211}$ In any event, two-thirds of the states flatly barred advertising by the medical profession. ${ }^{1212}$ The American Dental Association excluded any dentist from its membership who advertised, ${ }^{1213}$ a prohibition supported by statute in thirty-eight states. ${ }^{1214}$ The American Institute of Certified Public Accountants also forbade all advertising by members ${ }^{1215}$ as did the American Institute of Architects. ${ }^{1216}$ As for eyeglasses, over seventy percent of the states outlawed price advertising by optometrists and about forty percent by opticians as well.1217

1207. In the Virginia Pharmacy case, it was stipulated that in "Richmond the cost of 40 Achromycin tablets ranges from $\$ 2.59$ to $\$ 6.00 \ldots$ and that in the Newport News-Hampton area the costs of tetracycline ranges from $\$ 1.20$ to $\$ 9.00$, a difference of $650 \%$." 425 U.S. at 754 . The Court further noted that

[t]he American Medical Association conducted a survey in Chicago that showed price differentials in that city of up to $1200 \%$ for the same amounts of a specific drug. A study undertaken by the Consumers Union in New York found that prices for the same amount of one drug ranged from $\$ .79$ to $\$ 7.45$, and for another from $\$ 1.25$ to $\$ 11.50$. . . Amici American Association of Retired Persons and National Retired Teachers Association state that in 1974 they participated in a survey of three prescription drug prices at 28 pharmacies in Washington, D.C., and found pharmacy-to-pharmacy variances in the price of identical drugs as great as $245 \%$. . . . The prevalence of such discrepancies "throughout the United States" is documented in a recent report.

425 U.S. at 754 n. 11.

1208. In a survey of 131 senior citizens, $87 \%$ responded that they "would shop for the 'best buy' in drugs if the stores advertised their prices." Anderson \& Klippel, An Empirical Test of a Public Policy Decision Model: The Evaluation of Prescription Drug Price Advertising, in CoNTEMPORARY MARKeTING Thought 280, 283 (B. Greenberg \& D. Bellenger eds. 1977). A Federal Trade Commission study concluded that by eliminating restrictions on drug price advertising, consumer savings would be "of a very substantial magnitude, amounting to many millions of dollars per year.” STAFF REPORT TO FTC, supra note 1206, at 181.

1209. Model Code of Professional Responsibility, DR 2-101(A) (1975).

1210. AdVERTISING AGE, July 4, 1977, at 51.

1211. See In re American Medical Association, 94 F.T.C. 701, $815-36$ (1979).

1212. AdVERTISING AGE, supra note 1210 , at 51.

1213. Swerdlow \& Staples, supra note 1199, at 34.

1214. Brief of American Dental Association as Amicus Curiae 3, Bates v. Arizona State Bar, 433 U.S. 350 (1977) (price advertising).

1215. Code of Professional Ethics Rule 502 (American Institute of Certified Public Accountants, 1973).

1216. Veraska, Architects, AdVERTISING AGE, Dec. 24, 1979, at S-7.

1217. Veraska, Regulations: Straightening Out a Legal Tangle, ADVERTISING AgE, Dec. 24, 1979, at S-2. 
It is, of course, still too early to measure the full and multifaceted impact of the Court's extension of first amendment coverage to commercial advertising by professionals. The contours of the doctrine are still evolving and the consequences for the marketplace remain to be better examined and understood. But certain matters have been fairly clearly established.

First, all official restraints on price advertising of drugs and eyeglasses are now invalid ${ }^{1218}$ and the consumer has been the financial beneficiary. Several surveys in the optometrical and prescription drug areas have shown that "retail prices often are dramatically lower than they would be without advertising." 1219 Probably the most widely cited empirical study of the effect of advertising prohibitions on consumer costs and behavior concerned eyeglasses - one of the few prescription items for which advertising regulations varied significantly. ${ }^{1220}$ It concluded that "advertising restrictions in this market increase the prices paid by 25 percent to more than 100 percent." 1221 It also reported that large commercial optometric firms stated that "the presence or absence of advertising restrictions affected their decision to move into new market areas" and that two firms declared that their prices "varied across states, with the higher prices in the states with advertising restrictions." 1222 In the year following the FTC's removal of advertising prohibitions for eyeglasses, the Commission claimed partial credit for holding the increasing price to $5.7 \%$, while the cost of all consumer goods rose by $11.3 \%$, and that of medical care by $9.3 \% .1223$ of at least equal importance, an independent investigation of the quality of ophthalmic examinations - which controlled for such variables as capital investment (office equipment technology) and labor (length of examination) - found that prices for the same quality service were sixteen percent higher in states that banned optometric and optician price advertising. 1224

Second, the evidence accumulated thus far suggests that the Justices' rejection of restraints on truthful advertising of the availability

1218. In June 1978, the FTC adopted a final regulation preempting all state laws against advertising of eye care and eyeglass prescriptions. See 16 C.F.R. $\$ 456.9$ (1984).

1219. Bates, 433 U.S. at 377 (citing J. CADY, Restricted AdVERTISING AND CoMPETITION: THE CASE OF RETAIL DRUGS (1976); Benham, The Effect of Advertising on the Price of Eyeglasses, 15 J. L. \& EcoN. 337 (1972)).

1220. Benham, supra note 1219 , at 338 .

1221. Id. at 344.

1222. Id. at 346.

1223. Eyeglasses and Prices, Advertising AGE, Dec. 24, 1979, at S-2.

1224. Feldman \& Begun, The Effects of Advertising: Lessons From Optometry, 13 J. HuMAN RESOURCES 247 (Supp. 1978). 
and price of routine legal services - an edict rapidly implemented by regulatory officials in virtually all states ${ }^{1225}$ - has also produced important results. A series of earlier ABA studies had concluded that there was a serious underutilization of the services of lawyers - e.g., "the middle $70 \%$ of our population is not being reached or served adequately by the legal profession."1226 The major reasons usually advanced for this perceived unfulfilled need were insufficient consumer information about attorneys competent to handle the particular problem ${ }^{1227}$ and feared cost of the services. ${ }^{1228}$

Several surveys strongly indicate that lawyer advertising can do much to remedy the public awareness problem. For example, a survey of the results of a 1977 Illinois Bar Association publicity campaign to alert consumers to the existence of certain types of legal services "indicated high degrees of consumer recall . . ., a favorable attitude shift in respondents' confidence in lawyers and a significant increase in behavioral intentions to have a will prepared."1229 In addition, the public's use of bar association lawyer referral services has been found to be "strikingly responsive to publicity."1230 Moreover, although sample polls revealed that in the first two years after the Bates decision, only about seven percent of the bar had engaged in advertising ${ }^{1231}$ (a figure that increased to thirteen percent after an additional four years), ${ }^{1232}$ its substantial use by at least some legal clinics suggests an expanded clientele "from the segment of the population which has not used an

1225. See Some Developments in Lawyer Advertising, ABA General Practice Section, 1979 SuRVEY OF THE LAW 40, 40 (July 1979); Tokarz, To the Association, There's No Rush, ADVertising AGE, Dec. 24, 1979, at S-2, S-4. For a summary of different types of state rules, see R. Billings, Prepaid Legal Services 168-71 (1981).

1226. ABA, ReVised HaNdBook on PREPaid Legal Services 2 (1972); see also ABA SPECIAL COMMITTEE ON AVAILABILITY OF Legal SERVICES 19 (Aug. 1969); B. CuRRAN \& F. Spaulding, The Legal Needs OF The Public 80-81 (1974).

1227. Bates, 433 U.S. at $370 \mathrm{n} .23$ and studies cited therein.

1228. 433 U.S. at 370 n.22 (citing ABA, Legal Services and the Public, 3 AlteRnatives 15 (1976); B. CuRRAN \& F. SPAULDING, supra note 1226, at 96).

1229. Smith \& Meyer, Attomey Advertising: A Consumer Perspective, 44 J. of Marketing Spring 1980, at 56, 58; see also Middleton, Ads Pay Off - In Image And Income, NATL. L.J., Mar. 5, 1984, at 1, col. 4, at 22, col. 1 (reporting on a 1983 A.B.A. study which found that advertising improved the public's image of lawyers).

1230. Walsh, President's Page, 62 A.B.A. J. 405,405 (1976). A 1974 survey found that in areas where there was no publicity, referral averaged 1.29 per 10,000 population; where the service was advertised in the yellow pages of the classified telephone directory, the rate increased to 10.36 per 10,000 ; in Burbank, California, where there was an extensive publicity campaign in newspapers and otherwise, the rate jumped to 87.3 per 10,000 .

Id. See also Hobbs, Lawyer Advertising: A Good Beginning But Not Enough, 62 A.B.A. J. 735 (1976).

1231. Law Poll, 65 A.B.A. J. 1014 (1979); see also Note, The Wisconsin Experience With Advertising Legal Services, 1979 WiS. L. REV. 1251, 1265.

1232. Law Poll, 70 A.B.A. J. 48 (June 1984). 
attorney before."1233 Thus, in the first six months following the Court's approval of lawyer advertising, it was estimated that the number of legal clinics had tripled ${ }^{1234}$ and within about two years had multiplied thirty-five times. ${ }^{1235}$ By 1979, it was reported that "[t]here are more legal clinics now in Boston than there were in the entire country three years ago."1236

Moreover, data from scattered sources ${ }^{1237}$ tends to confirm the Justices' cautious prediction that advertising by lawyers might well lower the price of legal services. ${ }^{1238}$ For example, at the time of the Bates decision in 1977, the Bates \& Steen clinic's fee for an uncontested divorce was $\$ 195$ as compared to the Arizona State Bar's Legal Services Program rate of $\$ 250 . .^{1239}$ A year later it was reported that in Phoenix the cost of an uncontested divorce dropped "from $\$ 350$ to as low as \$125"; "the inability to advertise kept prices artificially high," "said O'Steen. ${ }^{1240}$ Similar experiences abound. ${ }^{1241}$

1233. Note, supra note 1231 , at 1276.

1234. Slavin, Lawyers and Madison Avenue: How Attorneys are Handling the Freedom to Advertise, 6 BARRISTER 46, 47 (Summer 1979); Auerbach, The Case for Lawyers' Advertising: It Wins Clients, Wash. Post, June 20, 1978 at A1, col. 2.

1235. Bodine, Proliferation of Legal Clinics Continues; 550 More Were Born in Last 10 Months, NATL. L.J., Dec. 31, 1979, at 5, col. 1.

1236. Bodine, Legal Clinics: The Bargain Bar, NATL. L.J., Feb. 12, 1979, at 27, col. 2. As further examples, in the first year following Bates, Jacoby \& Meyers, "the oldest and one of the most successful clinics," increased its number of offices from 4 to 16 and its annual receipts per lawyer from $\$ 55,000$ to $\$ 85,000$. "Much of this gain can be attributed to the firm's reliance upon advertising, particularly via television. Since the clinic began a heavy television campaign, it has attracted about 2,500 new clients per month." Muris \& McChesney, Advertising and the Price and Quality of Legal Services: The Case for Legal Clinics, 1979 AM. B. Found. RESEARCH J. 179, 194-95. See generally Middleton, supra note 1229. The Baltimore-Washington-based Cawley \& Schmidt clinic tripled its branches from 6 to 18 and extended its operations into another 5 states; " 'advertising is 100 percent responsible for our expansion,' said Cawley," Auerbach, supra note 1234, at A5, col. 2, echoing a widely shared judgment as to cause and effect. See, e.g., Slavin, supra note 1234, at 47; Project, An Assessment of Alternative Strategies for Increasing Access to Legal Services, 90 YALE L.J. 122, 127, 131 (1980), and authorities cited therein; Bodine, supra, at 27 ("advertising is essential," according to the president of the American Legal Clinic Association).

1237. See generally ABA COMmission ON ADVERTISING, REPORT TO THE House OF DELEGATES 8 (Feb. 1979).

1238. Bates, 433 U.S. at 377.

1239. 433 U.S. at 382.

1240. Auerbach, supra note 1234, at A5, col. 2.

1241. In 1975, the average cost of an uncontested divorce in Maryland was $\$ 344$. A year later "Cawley, Schmidt \& Sharrow's Maryland Clinic was offering uncontested divorce services for \$150." Muris \& McChesney, supra note 1236, at 196. In Washington, D.C., the standard fee for an uncontested divorce had ranged between $\$ 350$ and $\$ 500$; in 1978, such divorces were "widely advertised at prices from $\$ 125$ to $\$ 150$." Auerbach, supra note 1234, at A5, col. 2. In 1978, Jacoby \& Meyers' southern California clinics declared that "[a]n ordinary will can be drawn up for \$40, whereas the traditional law office will charge about \$70." Lawyer Advertising: The Jury's Still Out, EvERYBODY's MONEY, Summer, 1978, at 8. Thus, in early 1979, it was reported that "when a clinic opens up, legal fees in the surrounding business community sink." Bodine, NATL. L.J., supra note 1236, at 1, col. 1. In 1981, an A.B.A. national survey on legal 
It is especially difficult to determine whether reduced fees attributable to lawyer advertising also result in diminished quality of service. In the most comprehensive impartial study to date, the authors "devised two tests to evaluate the assertion that clinics must provide lower quality services if they charge lower prices." 1242 Their "subjective" measure was based on a mail questionnaire to Los Angeles consumers concerning their satisfaction with the legal services they had received either from traditional law firms or from the Jacoby \& Meyers legal clinic. Factors included promptness in delivering services, interest in the problem, honesty, full explanation of matters, progress reports, attentiveness to clients' statements and fairness of fees. ${ }^{1243}$ Although the survey may be subject to methodological criticism - particulary because the sample was drawn from the clinic's mailing list ${ }^{1244}$ - its results disclosed that in all categories, users of the legal clinic showed greater satisfaction than users of traditional firms, the most significant difference concerning fairness of prices. ${ }^{1245}$ The "objective" measure involved child support cases, a substantial part of the clinics' business. To determine objective quality, support awards were compared with the income and expenses of the wife (who always had custody) and the husband. The results showed that child support decreased for husbands when represented by the clinic (though not to a statistically significant degree) and increased for wives (to a statistically significant degree) when they had clinic representation. ${ }^{1246}$ Overall, it is fair to conclude that "[i]n both sets of tests, it appears that, to the extent that a difference exists, the quality of services of the Legal Clinic of Jacoby \& Meyers is superior to that of the traditional firms."1247

It is as yet unknown whether similar consequences respecting consumer information and price of services will occur in other professions - such as accounting ${ }^{1248}$ and architecture ${ }^{1249}$ - where longstanding

clinics found that "the average set fees and/or the stated hourly rate for . . . [divorce and bankruptcy] services [of clinics] appear to be below what one might expect for a traditional law firm." ABA Special Commitee on the Delivery of Legal Services, Legal Clinics: Merely ADVertising LAw Firms? 7-8 (1982). See also id. at 48. Finally, a 1984 Federal Trade Commission study of 3200 lawyers in 17 cities concluded that the price of many routine legal services was from $5 \%$ to $13 \%$ lower where lawyer advertising was more extensive. N.Y. Times, Dec. 7, 1984, at A24, col. 3.

1242. Muris \& Chesney, supra note 1236, at 196.

1243. Id. at 199.

1244. For the authors' fuller explanation and justification, see id. at 197 n.57.

1245. Id. at 199.

1246. Id. at 205.

1247. Id. at 196.

1248. See Osterlund, Advertising - In the Public Interest?, 145 J. Acct. 59 (Jan. 1978); Smith, Reaching the Public: The CPA's New Image, 149 J. AccT. 47 (Jan. 1980); Wood \& Ball, New Rule 502 and Effective Advertising by CPAs, 145 J. Accr. 65 (June 1978). 
ethical bars against advertising have been relaxed in response to the Justices' pronouncements. However, fragmentary evidence from the area of dentistry, ${ }^{1250}$ which has modified its prohibition to conform to the Bates ruling, ${ }^{1251}$ suggests the same meaningful effects for patients and practitioners as has come about in the fields of law and pharmacy.

\section{Patronage}

At the end of the 1970's, employees of state and local governments comprised nearly fifteen percent of the nation's work force. ${ }^{1252}$ Although, at the beginning of the decade, virtually every state had some form of civil service system, ${ }^{1253} 1978-1979$ statistics disclose that more than one-third of the 3.5 million state employees fell outside their coverage. ${ }^{1254}$ Moreover, some counties and cities had no civil service systems at all, ${ }^{1255}$ thus suggesting that the positions of an even larger percentage of their 9.2 million jobholders ${ }^{1256}$ potentially depended on their partisan political affiliation.

In states such as Oregon and Wisconsin, the governor possessed just a handful of patronage jobs, and in California, only a few hundred.1257 However, the partial information and anecdotal data collected from other states indicated that a great many people were, in fact, affected by the tradition of political spoils. In Pennsylvania, it was estimated that the governor was capable of making up to 50,000 political appointments. ${ }^{1258}$ In New York, the governor has approxi-

1249. See Tokarz, supra note 1225, at S-2; Veraska, supra note 1216, at S-7.

1250. "Advertising by dentists is particularly widespread in California where it is estimated that as much as five percent of the state's 14,000 dentists have advertised at some time." Swerdlow \& Staples, supra note 1199, at 34. (footnote omitted)

After three months of television advertising, a Philadelphia dentist named Stanley Wasko reported that he had "expanded his staff of dental technicians from one to six, and he plans to employ another dentist to handle nondenture work. Wasko says that the dentures he sells for $\$ 155$ cost as much as $\$ 450$ from other Philadelphia dentists." BusLNESS WEEK, July 24, 1978, at 122. After nine months of newspaper advertising, a Westchester County, N.Y. dental group claimed that "across the board [its] fees are $30 \%$ to $40 \%$ lower than those charged by private practitioners in Westchester" and that since the ads began running business has risen $20 \%$. Id.

1251. Swerdlow \& Staples, supra note 1199, at 34.

1252. Bureau of the Census, U.S. Dept. of Commerce, Statistical Abstract of THE UNITEd STATES 319, 421 (1980) (13,102,000 state and local government employees; 96,945,000 employed persons). (1975).

1253. Peirce, Civil Service Systems Experience "Quiet Revolution", 7 NATL. J. 1643, 1644

1254. 23 BOOK OF THE STATES 248-49, 271 (1980) (2,247,309 employees covered in 50 states and District of Columbia; 3,539,325 total state employees).

1255. Peirce, supra note 1253 , at 1644.

1256. BOOK OF THE STATES, supro note 1254, at 271.

1257. R. Wolfinger, M. Shapiro \& F. Greenstein, Dynamics of American Politics 177 (1976).

1258. Id. "During the early 1960's Pennsylvania Republicans under Governor William 
mately 39,000 positions at his disposal ${ }^{1259}$ and the mayor of New York City has more than twice that amount. ${ }^{1260}$ In Illinois, when Richard Daley was both mayor of Chicago and Chairman of the Cook County Democratic Committee, he controlled 35,000 patronage jobs. ${ }^{1261}$ In Indiana, nearly 8,000 state employees are subject to the spoils system. ${ }^{1262}$ In West Virginia, when a Republican succeeded a Democrat in the statehouse in 1969 , about 3,400 of the roughly 4,000 maintenance employees were replaced on the basis of political criteria. ${ }^{1263}$

Since many American cities, especially the larger ones, have civil service requirements for most employees, 1264 it may be inferred that the issue of political patronage was of limited consequence. But, as the figures from New York and Chicago reveal, political realities and administrative loopholes have greatly diluted the impact of the formal rules. ${ }^{265}$ Furthermore, the reach of patronage tentacles extended beyond the state and locally funded positions to many federal jobs when they were assigned from Washington through mayors with national clout. ${ }^{1266}$ Finally, the magnitude of the subject was compounded by the fact that public jobholders in a number of states - such as Illinois, Indiana, Missouri, New York, Oklahoma and Pennsylvania - were required to pay a kickback for continued employment. ${ }^{1267}$

Scranton 'laid off' some 7,800 Democrats in the Department of Transportation and replaced them with Republicans. . . The 1970 Pennsylvania election of Democrat Milton Shapp was followed by the dismissal of some 3,500 Republicans in a "highway department reorganization." Recent Cases, Public Employees - Freedom of Association - Discharge of Non-policymaking Public Employees on Ground of Political Affiliation. Infringes Employees' Freedom of Association, 26 VAND. L. REV. 1090, 1091 n.8. (1973).

1259. R. Wolfinger, M. SHAPIRo \& F. GREENSTEIN, supra note 1257, at 177.

1260. "During the first three years of Mayor Lindsay's regime the number of 'provisional' employees increased from 1,500 to 12,800. Under Mayor Wagner the City of New York also had 50,000 'noncompetitive' jobs; 24,000 more such positions were added after Lindsay took office." R. Wolfinger, The Politics of Progress 90 (1974) (footnote omitted).

1261. Id. at 91. When Richard Ogilvie, a Republican, became Governor of Illinois, he dismissed 10,000 state employees who had been appointed by prior Democratic administrations. $M$. TOLChIN \& S. TOLchIN, To THE VICTOR 97 (1971). The Illinois Secretary of State reportedly commands the destinies of some 4,000 workers. See Recent Cases, supra note 1258, at 1091 n.8. Within six months of a Democrat's ousting the Republican sheriff in Cook County, Illinois (Chicago) in 1970, all but 240 of the more than 1,500 non-civil servants in that office - including window washers, janitors, clerks, elevator operators and caseworkers - were fired for political reasons. Brief of Independent Voters of Illinois, et al. as Amici Curiae at $4 \&$ Amicus Curiac Brief of Public Citizens at 11-12 [hereinafter cited as Brief of Public Citizens], Elrod v. Burns, 427 U.S. 347 (1976).

1262. M. Tolchin \& S. Tolchin, supra note 1261 , at 118.

1263. Brief of Public Citizens, supra note 1261, at 9-10.

1264. U.S. Commn. on Civil Rights, For All the People . . . By All the People 63-64 (1969).

1265. See R. WolfiNger, supra note 1260 , at 89.

1266. See M. TolChiN \& S. TolchiN, supra note 1261 , at 72.

1267. See id. at 116-17. 
Although all of the adverse consequences of patronage are beyond measurement, it is clear that they have been substantial. For example, it has been urged that the operation of the patronage system in Chicago's courts, jails, sheriff's office and hospitals caused their functions to deteriorate, "as employees with backgrounds of political service take precedence over those with technical training."1268 Critics of Mayor Lindsay's use of patronage in the New York City Corporation Counsel's office claimed that "due to its inexperienced legal staff, the city has lost many cases in court," 1269 and it is common knowledge that lawmakers' votes often turn on the rewards of patronage rather than on the merits of the issue at stake. ${ }^{1270}$

Whether the Court's rulings in Elrod v. Burns ${ }^{1271}$ and Branti v. Finkel 1272 - forbidding the discharge of public employees on the sole ground of their political affiliations unless "the hiring authority can demonstrate that party affiliation is an appropriate requirement for the effective performance of the public office involved" 1273 - will remedy all the abuses is highly uncertain. It is equally unclear whether the strictures of these decisions will be held applicable to other patronage practices such as the use of partisan criteria for awarding government contracts; for promotions, demotions, initial hirings, and reappointments in general; 1274 for application to such persons as police, firefighters, teachers, referees, trustees, guardians and receivers; ${ }^{1275}$ and for hiring the required army of federal census takers. 1276 Indeed, it may well be that, on balance, extensive judicial prohibition of the patronage scheme, which has been a basic prop of the nation's traditional political party system, is a naive act of reformism that will further contribute to the widely perceived crisis in American democracy resulting from the decline of our two major political parties. ${ }^{1277}$ How-

1268. Id. at 43.

1269. Id. at 65 .

1270. As a single example, when a Georgia legislator had announced his intention to vote against a bill sought by the governor, the latter "sent back word that . . . [the legislator's] brother would lose his job in the state highway department unless the legislator complied." Id. at 92-93.

1271. 427 U.S. 347 (1976).

1272. 445 U.S. 507 (1980).

1273. 445 U.S. at 518.

1274. For discussion of recent lower court rulings, see Note, First Amendment Limitations on Patronage Employment Practices, 49 U. CHI. L. REV. 181 (1982).

1275. See R. WOLFINGER, supra note 1260 , at 79-80, 90-91.

1276. See Keegan, House Democrats Want to Be In On the 1980 Census 'Dole', 11 NATL. J. 1681 (1979).

1277. See, e.g., Ranney, The Political Parties: Reform and Decline, in THE NEW AMERICAN Political System (A. King ed. 1978); Burnham, American Politics in the 1970's: Beyond Party?, in The American Party Systems: Stages of Polmtical Development (W. Chambers \& W. Burnham eds. 2 d ed. 1975). 
ever, there can be little disputing that the Court's condemnation of the soul of the political spoils system promises to remove substantial restraints on the freedoms of belief and association of a significant number of citizens, even if its import is not brought fully to bear.

\section{Access to Criminal Trials}

Although there had been a small handful of reported cases in which designated classes of persons had been excluded from limited parts of a criminal trial in special circumstances, ${ }^{1278}$ in 1948 the Supreme Court said that it was "unable to find a single instance of a criminal trial conducted in camera in any federal, state, or municipal court during the history of this country." 1279 Three decades later, the American Civil Liberties Union found that "never, to . . . [its] knowledge, had any American court undertaken to close an entire criminal trial to the public" prior to $1979 . .^{1280}$ While there may be isolated cases that could be cited as contrary to these unqualified statements, ${ }^{1281}$ it is undisputed that "if any . . . exist, which is doubtful, they are few indeed." 1282

Nonetheless, within only a year following the Court's suggestion in Gannett Co. v. DePasquale 1283 that neither the public nor the press has any first amendment right to observe criminal trials, ${ }^{1284}$ there were nearly fifty attempts to close such proceedings, nearly two-thirds of which were successful, ${ }^{1285}$ a number that promised to grow significantly unless abated by the Justices. The Court's ruling in Richmond Newspapers, Inc. v. Virginia 1286 explicitly did not hold that the Constitution grants the public and representatives of the press an absolute first amendment right of access to criminal trials. ${ }^{1287}$ Nor, though

1278. See Gannett Co. v. DePasquale, 443 U.S. 368, 388 n.19, 430-32 n.11 (1979).

1279. In re Oliver, 333 U.S. 257, 266 (1948).

1280. Brief of the American Civil Liberties Union in Support of Jurisdictional Statement as Amicus Curiae at 3, Richmond Newspapers, Inc. v. Virginia, 448 U.S. 555 (1980); see also Brief of Washington Post et al. as Amici Curiae at 14, Richmond Newspapers, Inc. v. Virginia, 448 U.S. 555 (1980).

1281. See, e.g., Gannett, 443 U.S. at 430 n.11 (Blackmun, J., dissenting); Kirstowsky v. Superior Court, 143 Cal. App. 2d 745, 300 P.2d 163 (1956); Dutton v. State, 123 Md. 373, 91 A. 417 (1914).

1282. Gannett, 443 U.S. at 431 n.11 (Blackmun, J., dissenting).

1283. 443 U.S. 368, 391-93 (1979).

1284. The Court did not reach the issue of whether such a right reposed in the first amendment although one of the concurrences argued that it did not. See 443 U.S. at 403-06 (Rehnquist, J., concurring). But see 443 U.S. at 398 (Powell, J., concurring).

1285. Reporters Committee for Freedom of the PrEss, COURT Watch SUMmary (Nov. 1980).

1286. 448 U.S. 555 (1980).

1287. 448 U.S. at 581 n. 18. 
Richmond Newspapers may be a "watershed case," 1288 may it be predicted with full confidence that its constitutionally based "right to attend criminal trials"1289 will extend to civil trials, ${ }^{1290}$ much less to public access to other governmental proceedings or information. ${ }^{1291}$ However, it is clear beyond peradventure that the decision's recognition that "a presumption of openness inheres in the very nature of a criminal trial under our system of justice" 1292 will markedly advance the first amendment's "core purpose of assuring freedom of communication on matters relating to the functioning of government"1293 and will provide protection to the individual rights of the press and public arising therefrom. ${ }^{1294}$

\section{Right of Reply Laws}

At the time of the Court's 1974 decision in Miami Herald Publishing Co. v. Tornillo1295 - holding that Florida's "right of reply" statute, which obliged "newspapers" to print without charge the reply of any political candidate "assailed" by the newspaper, ${ }^{1296}$ violated the first amendment - only North Carolina had such a law. ${ }^{1297}$ However, there was a real possibility of additional moves in this direction, particularly if the Justices had reached a different result. A "number

1288. 448 U.S. at 582 (Stevens, J., concurring). See generally Press Hails Court's Richmond Ruling, Presstime, Aug. 1980, at 10.

1289. 448 U.S. at 580.

1290. 448 U.S. at 580 n.17.

1291. See J. Choper, Y. Kamisar \& L. Tribe, The Supreme Court: Trends and DEVELOPMENTS, 1979-1980, at 145-96 (1981); Lewis, A Public Right to Know About Public Institutions: The First Amendment as Sword, 1980 SUP. CT. REV. 1, 19-25.

1292. 448 U.S. at 573.

1293. 448 U.S. at 575 .

1294. The Court has further extended and clarified the scope of these rights in Globe Newspapers v. Superior Court, 457 U.S. 596 (1982).

1295. 418 U.S. 241 (1974).

1296. The statute was applied "[i]f any newspaper in its columns assails the personal character of any candidate for nomination or for election in any election, or charges said candidate with malfeasance or misfeasance in office, or otherwise attacks his official record, or gives to another free space for such purpose." FLA. STAT. § 104.38 (1973).

1297. Bagdikian, First Amendment Revisionism, ColuM. Jour. Rev. May-June 1974, at 39, 42. Mississippi's statute had been construed to apply only when the newspaper's original publication was actually defamatory. See Manasco v. Walley, 216 Miss. 614, 63 So. 2d 91 (1953). Nevada's provision had been replaced by a retraction statute in 1969. Act of Mar. 29, 1967, ch. $211, \S 71,1967 \mathrm{Nev}$. Stat. 458, 473, repealed by Act of Apr. 14, 1969, ch. 310, §101969 Nev. Stat. 553, 554 (codified as replaced at Nev. REv. STAT. \$ 41.336 (1969). In Miami Herald, Justices Brennan and Rehnquist wrote separately to emphasize their understanding that the Court "implies no view upon the constitutionality of 'retraction' statutes affording plaintiffs able to prove defamatory falsehoods a statutory action to require publication of a retraction." 418 U.S. at 258. 
of other states ha[d] introduced similar bills" in 19741298 and Senator John McClellan, then the Chairman of the Senate Judiciary Committee, had stated on the Senate floor that if the Court upheld Florida's regulation he would propose federal legislation affecting the press throughout the country. ${ }^{1299}$

Although the Florida law had itself been virtually unenforced over its sixty-one-year life, ${ }^{1300}$ the potential chill of its gestating progeny on an independent and informative press appeared to be substantial. In addition to "the cost in printing and composing time and materials and in taking up space that could be devoted to other material the newpaper may have preferred to print,"1301 the possibility of these burdens might lead editors - as a similar rule has reportedly influenced broadcasters ${ }^{1302}$ - to modify drastically their normal coverage of electoral affairs. Thus, the New York Times and Wall Street Journal contended that, under the Florida regime,

[e]very politically oriented editorial or letter to the editor will be published with the fear that, as a result of its publication, part of the content of tomorrow's editorial page will be dictated by a politician seeking office. Every page-one story about legislators or other elected officials may carry with it the possibility that the legislator or official will be the author of a portion of a future front page. It is painfully clear that those conditions will lead not to debate, but to a stifling degree of restraint in political reporting by newspapers. ${ }^{1303}$

The Washington Post believed that "[a]ny newspaper worthy of the First Amendment trust vested in it by the Founding Fathers will think twice before opening its pages to an invasion of self-serving press releases." 1304

Although an increasing number of prominent dailies had voluntarily opened access to opposing views, 1305 the dilemma faced by "marginal or ideologically oriented newspapers"1306 (and other journals of

1298. Bagdikian, supra note 1297 , at 42 ; see also W. FrancoIs, MASS MEDIA LAw AND REGULATION 513 (2d ed. 1978) (right of reply law proposed in Hawaii).

1299. See 120 Cong. Rec. $1855-59$ (daily ed. Feb. 4, 1974).

1300. Prior to the Miami Herald litigation, "the law had been invoked only once before, in 1971 in a case involving the Daytona Beach Morning Journal. The judge in that case said that the law was 'clearly unconstitutional' and dismissed the case." Stencel, Access to the Media, 1 EDITORIAL RESEARCH REP. 449, 450 n.3 (1974).

1301. 418 U.S. at 256.

1302. See, e.g., E. EPSTEIN, News From NowhERE 69-72 (1974).

1303. Brief of Dow Jones \& Co., and The New York Times Co. as Amici Curiae at 3, Miami Herald Publishing Co. v. Tornillo, 418 U.S. 241 (1974).

1304. Brief of The Washington Post Co. as Amicus Curiae at 4, Miami Herald Publishing Co. v. Tornillo, 418 U.S. 241 (1974).

1305. See Chatzky \& Robinson, A Constitutional Right of Access to Newspapers: Is There Life After Tornillo?, 16 SANTA Clara L. REv. 453, 492 (1976).

1306. Brief of The Washington Post Co., supra note 1304, at 10. 
opinion) posed an even greater threat to the vigorous public debate promised by a free press. On the one hand, "many of these newspapers cannot afford to print free extra copy."1307 But neither

can they afford to eliminate the critical viewpoints which are the basis of their appeal to a select audience. Journals with a recognized political viewpoint, like the National Review or the New Republic, may lose their readers if they are forced to fill their pages with self-serving responses from criticized candidates. ${ }^{1308}$

Finally, there was good reason to believe that if Florida's right-ofreply for political candidates had been held to pass constitutional muster, extensions of its policy to press criticism of incumbent officials and ultimately to news coverage of all subjects would follow. Thus, despite the definite doctrinal limits of the Miami Herald principle, ${ }^{1309}$ the Justices' mandate promised to deter further compounding the danger to robust and uninhibited reporting and commentary.

\section{Compulsory Unionism}

Although the Taft-Hartley Act specifically excludes governmental employees from its protective coverage for labor union organization and activities, ${ }^{1310}$ as of the mid-1970's over one-third of the states had enacted comprehensive statutes authorizing collective bargaining for all state and local government workers, and nearly a dozen more states made some type of more limited provisions. ${ }^{1311}$ As a result, in 1976 , almost half of all full-time nonfederal public employees belonged to some union organization ${ }^{1312}$ which had power to act as the exclusive bargaining agent for any bargaining unit in which the union represented a majority of employees. The union's duty to represent fairly all workers in the bargaining unit ${ }^{1313}$ carries "a corresponding duty on the part of everyone in that bargaining unit to bear a proportionate share of the cost of fair representation, giving rise to various forms of

1307. Id.

1308. $I d$.

1309. See Red Lion Broadcasting Co. v. FCC, 395 U.S. 367 (1969) (upholding right of reply obligation for broadcast media).

1310. See 29 U.S.C. § 152(2) (1982).

1311. See Zwerdling, The Liberation of Public Employees: Union Security in the Public Sector, 17 B.C. IND. \& COMM. L. REV. 993-94 n.5 (1976). A presidential order also granted federal executive branch employees some collective bargaining rights. See Exec. Order No. 11,838, 3 C.F.R. 957 (1975).

1312. U.S. DePT. OF COMMERCE \& U.S. Dept. OF LABOR, LABoR-MANAGEMENT RelaTIONS IN STATE AND LOCAL GoverNMENTS: 1980, at 1 (State and Local Government, Special Studies No. 102, 1981).

1313. See Steele v. Louisville \& N.R.R., 323 U.S. 192 (1944). 
union security arrangements"1314 - the usual being either the employee's obligation actually to become a union member (union shop); or, without joining the union, to pay a sum equal to union dues (agency shop); or to pay a service fee in an amount less than union dues (fair share agreement). ${ }^{1315}$ Although the examples of highly successful political action by labor groups in states without provisions for public employee collective bargaining ${ }^{1316}$ demonstrate that legal security for the union is not a prerequisite to effectiveness, the financial significance of the nonunion members' responsibility to contribute may be gleaned from a recent - albeit perhaps atypical - case in which the additional revenue generated by the representation fee roughly doubled the local's annual income. ${ }^{1317}$

Primarily for two reasons, ${ }^{1318}$ the precise scope of the Court's 1977 decision in Abood v. Detroit Board of Education ${ }^{1319}$ - holding that the first amendment forbids the exclusive bargaining representative from spending the public employees' fees for any political or ideological causes unrelated to collective bargaining without the consent of the worker - remains somewhat indefinite. First, the Justices have not yet authoritatively determined whether the employees' constitutional rights are adequately safeguarded by a rebate procedure ${ }^{1320}$ - required by a number of states ${ }^{1321}$ and adopted by such powerful public employee unions as AFSCME ${ }^{1322}$ and the NEA $^{1323}$ - under which

1314. Note, Union Security in the Public Sector: Defining Political Expenditures Related to Collective Bargaining, 1980 WIs. L. REv. 134.

1315. Id. at 134 n.4.

1316. See, e.g., Shaw \& Clark, The Practical Differences Between Public and Private Sector Collective Bargaining, 19 UCLA L. REV. 867, 951, $953-54$ (1972) (Arkansas \& District of Columbia).

1317. Robinson v. New Jersey, 547 F. Supp. 1297, 1304 (D.N.J. 1982), revd., 741 F.2d 598 (3d Cir. 1984).

1318. Although both issues were recently presented in Ellis v. Brotherhood of Ry., Airline \& S.S. Clerks, 104 S. Ct. 1883 (1984), the Court construed the Railway Labor Act to avoid having to decide any significant issues of constitutionality.

1319. 431 U.S. 209 (1977).

1320. See 431 U.S. at 242 n.45. For varied resolutions by lower courts, see Perry v. International Assn. of Machinists, 708 F.2d 1258 (7th Cir. 1983); Robinson v. New Jersey, 547 F. Supp. 1297 (D.N.J. 1982), 565 F. Supp. 942 (D.N.J. 1983), revd., 741 F.2d 598 (3d Cir. 1984); White Cloud Educ. Assn. v. Board of Educ., 101 Mich. App. 309, 300 N.W.2d 551 (Mich. Ct. App. 1980). In Ellis, the Court held that a rebate scheme was not permitted by the Railway Labor Act.

1321. See e.g., MAss. Gen. LAws c. 150E $§ 12$ (Michie/Law Coop. Supp. 1984); N.J.STAT. ANN. § 34:13-A-5.5-5.6 (West Supp. 1984); N.Y. Civ. SERV. LAW § 208(3)(a) (McKinney 1983); see generally Note, New York Legislative Response to Abood v. Detroit Board of Education: Agency Shop and Public Employees' Rights to Freedom of Association, 43 ALB. L. REV. 567 (1979).

1322. See Zwerdling, supra note 1311, at 1036-37.

1323. See Federal Election Commn. v. NEA, 457 F. Supp. 1102 D.C. 1978). 
the union collects an amount (usually through payroll deduction) that includes political action fees and then offers a partial refund on request. Although the number of dissenters that recover under this scheme is not insubstantial, ${ }^{1324}$ the dynamics of inertia would appear to make it only a relatively small fraction of those who would withhold if asked affirmatively to contribute. ${ }^{1325}$ Second, the line between the union's engaging in "collective bargaining activities"1326 (for which it may assess) and spending funds "for the expression of political views, on behalf of political candidates, or towards the advancement of other ideological causes not germane to its duties as collectivebargaining representative"1327 (for which it may not charge without consent) remains relatively ambiguous and extremely difficult to draw satisfactorily. ${ }^{1328}$ Obviously, both of these factors will greatly affect the full sweep of $A b o o d$ 's protection for the personal right of public employees against having their compulsory fees expended for causes with which they disagree.

Although the Justices' constitutional holding will have a capacious impact on individual liberty even if ultimately applied minimally as to public employees, its doctrinal implications potentially extend to the private sector as well where, at present, the issue is largely regulated by federal statutes. First, in several earlier decisions, ${ }^{1329}$ the Court construed the Railway Labor Act's guarantee of a union shop for railway employees ${ }^{1330}$ to avoid the first amendment questions "of utmost gravity"1331 that were presented in $A b o o d$. On the premise that congressional authorization and judicial enforcement of union security devices represented "governmental action"1332 subject to constitutional constraints, the Court interpreted the statute to prohibit the use of compulsory union fees "to finance the campaigns of candidates for federal and state offices whom [the plaintiffs] opposed, and to promote the propagation of political and economic doctrines, concepts and ideolo-

1324. See Olsen v. Communications Workers of Am., 559 F. Supp. 754, 758 (D.N.J. 1983), revd. sub nom. Robinson v. New Jersey, 741 F.2d 598 (3d Cir. 1984).

1325. See Federal Election Commn. v. NEA, 457 F. Supp. 1102, 1107-08 (D.D.C. 1978).

1326. Abood, 431 U.S. at 236.

1327. 431 U.S. at 235.

1328. For contrasting approaches, see Nelson, Union Dues and Political Spending, 28 LAB. L.J. 109 (1977); Note, supra note 1314, at 142-48; Robinson v. New Jersey, 547 F. Supp. 1297, 1316-17 (D.N.J. 1982). See generally Ellis, 104 S. Ct. at 1890-97.

1329. See Brotherhood of Ry. \& S.S. Clerks v. Allen, 373 U.S. 113 (1963); Railway Employees' Dept. v. Hanson, 351 U.S. 225, $235-38$ (1956).

1330. See 45 U.S.C. § 152 Eleventh (1982).

1331. International Assn. of Merchants v. Street, 367 U.S. 740, 749 (1961).

1332. Railway Employes' Dept. v. Hanson, 351 U.S. 225, 232 \& n.4 (1956). 
gies with which [they] disagreed."1333 Second, the federal courts of appeals have construed a virtually identical provision of the National Labor Relations Act ${ }^{1334}$ (which governs most nonrailroad private employees) ${ }^{1335}$ as imposing the same restriction, ${ }^{1336}$ and labor unions accordingly adopted a rebate procedure. ${ }^{1337}$ Third, the Federal Election Campaign Act ${ }^{1338}$ forbids labor unions from using compulsory fees to make any contributions or expenditures in support of any federal election campaign (as distinguished from state or local elections and federal lobbying activities). ${ }^{1339}$

In sum, the interpretation of existing federal legislation by courts appears to be at least as solicitous of dissenting private employees' rights as the Court's constitutional ruling in Abood. Moreover, if Congress were to repeal the pertinent sections of the Railway Labor Act and the National Labor Relations Act and enact a national right-towork law, the influence of (and need for) the Abood doctrine in the private sector would be totally eliminated. Short of this fundamental change of policy, if Congress were to overturn the judicial interpretation of either or both of these statutes, there is no assurance that the result would be invalid under $A b o o d$, for the Court's assumption of "governmental action" under the Railway Labor Act does not constitute a square holding. Some federal courts of appeals have declined in any event to extend it to the National Labor Relations Act (judgments seemingly based more solidly on the Burger Court's conservatism in respect to the "state action" concept than on the logic of the Justices' earlier reasoning). ${ }^{1340}$ Apart from these quite unlikely contingencies,

1333. International Assn. of Merchants v. Street, 367 U.S. 743, 744 (1961).

1334. 29 U.S.C. $\S 158(a)(3)$ (1982).

1335. Unlike the Railway Labor Act, which preempts state right-to-work laws, the National Labor Relations Act does not guarantee union security schemes when a majority in the bargaining unit opt for representation, but rather allows states to proscribe union shop agreements. 29 U.S.C.§ 164(b) (1982). Since fewer than half the states (largely those in the south and southwest) have adopted right-to-work legislation, a substantial majority of American workers are subject to the NLRA's authorization of compulsory union fees. See Kovach, National Right to Work Law: An Affirmative Position, 28 LAB. L.J. 305, 305 (1977).

1336. See, e.g., Reid v. McDonell Douglas Corp., 443 F.2d 408, 411 (10th Cir. 1971); Seay v. McDonnnell Douglas Corp., 427 F.2d 996, 1000, 1003-04 (9th Cir. 1970). For a contrary reading of the legislative history, see Note, The National Labor Relations Board's Role in Exemption of the Use of Union Dues Collected Pursuant to a Union Security Agreement, 67 Mich. L. Rev. 152, 159 (1968).

1337. See Nelson, supra note 1328 , at 113.

1338. 2 U.S.C. $\S \S 441 \mathrm{a}-441 \mathrm{~b}$ (1982) (amending 2 U.S.C. $\S \S 431-441$ (1971)).

1339. See discussion in Pipefitters Local Union v. United States, 407 U.S. 385 (1972).

1340. Compare Kolinske v. Lubbers, 712 F.2d 471, 476-80 (D.C. Cir. 1983), and Reid v. McDonnell Douglas Corp., 443 F.2d 408, 410-11 (10th Cir. 1971), with Linscott v. Miller Falls Co., 440 F.2d 14, 16-17 (1st Cir.), cert. denied, 404 U.S. 872 (1971), and Seay v. McDonnell Douglas Corp., 427 F.2d 996, 1003-04 (9th Cir. 1970). 
however, there is no disputing the fact that the Court's constitutional principle has generated the current significant protection for the associational rights of private employees and stands powerfully against any congressional reversal or diminution of those rights.

Finally, whatever the ambiguities of Abood's application to private employment, there appears to be little room for disagreement with the conclusion of every state and federal court addressing the question ${ }^{1341}$ that the rule covers the integrated (or unified) bar requirement - existing in nearly sixty percent of jurisdictions and affecting more than two-thirds of the nation's attorneys ${ }^{1342}$ - that all practicing lawyers pay dues to the state bar association. ${ }^{1343}$ Although, again, the exact reach of the $A b o o d$ doctrine in this context is still unsettled, ${ }^{1344}$ the fact that, as of 1980, two-thirds of these bar associations employed paid full time lobbyists and almost one-sixth funded political action committees ${ }^{1345}$ discloses the importance of the Justices' edict for individual liberty even in much smaller groups than those involved in public employee unions.

\section{E. Religious Freedom}

\section{Compulsory Education Laws}

In 1971, members of the Old Order Amish could be found in nineteen states in the United States. ${ }^{1346}$ According to the tenets of their faith, Amish parents believed that formal education of their offspring beyond the eighth grade would "endanger their own salvation and that of their children."1347 They feared that "the public schools will melt all men into one and thereby destroy or fatally weaken the

1341. See, e.g., Schneider v. Colegio de Abogados de Puerto Rico, 565 F. Supp. 963 (D.P.R. 1983), vacated sub nom. Romany v. Colegio de Abogados de Puerto Rico, 742 F.2d 32 (1st Cir. 1984); Arrow v. Dow, 544 F. Supp. 458 (D.N.M. 1982); In re Amendment to the Integration Rule of the Florida Bar, 439 So. 2d 213 (Fla. 1983); Falk v. State Bar, 411 Mich. 63, 305 N.W.2d 201 (1981); see also Report of the Committee to Review the State Bar, 334 N.W.2d 544 (Wis. 1983) (assuming arguendo Abood applicable). Cf. Reynolds v. State Bar of Montana, 524 F. Supp. 1003 (D. Mont. 1981).

1342. ABA, Directory of Bar Activities 4 (J. Sweeney ed. 1980).

1343. The constitutional issue was left unresolved in Lathrop v. Donahue, 367 U.S. 820 (1961). The same logic would seem to apply to mandatory fees from state college students to support the student government association.

1344. See text at notes 1320-28 supra. See also Falk v. State Bar of Michigan, 418 Mich. 270, 342 N.W.2d 504 (1983) cert. denied, 105 S. Ct. 315 (1984).

1345. See ABA, supra note 1342, at 20-21.

1346. N.Y. Times, Feb. $21,1971, \S 1$, at 43 , col. 1. They resided "principally in the rural areas of Pennsylvania, Ohio, and Indiana, and in smaller settlements in Illinois, Iowa, Wisconsin, Tennessee, Missouri, Maryland, Kansas, and New York." J. HostetLER \& G. HunTINGTON, ChIldREN IN AMISH SOCIETY 3 (1971).

1347. Wisconsin v. Yoder, 406 U.S. 205, 209 (1972), 
Amish church." 1348 As a result, despite state compulsory education laws, in 1970 there were approximately 10,000 Amish youngsters enrolled in Amish schools outside the public education system ${ }^{1349}$ (including many high-school-age children in "vocational schools"1350) in addition to an unknown number of secondary-school-age children who attended no school at all. ${ }^{1351}$

Over the years, in as many as nine states, ${ }^{1352}$ the Amish had been "repeatedly prosecuted for their failure to submit to compulsory attendance laws." 1353 In Ohio, during the first third of the twentieth century, Amish parents frequently suffered fines and jail sentences. ${ }^{1354}$ In Pennsylvania, between the mid-1930's and the mid-1950's, Amish fathers were convicted in several judicial decisions. ${ }^{1355}$ In Indiana, in 1948 , a father's sixty-day prison sentence was affirmed on appeal ${ }^{1356}$ and, although the state had no teacher certification requirement for nonpublic schools, the state closed an Amish school because of teacher qualifications. ${ }^{1357}$ In Kansas, in the mid-1960's, a father whose conviction had been affirmed by the state supreme court 1358 "was harassed out of the state . . . for not enrolling his daughter in a public high school. Another Kansas Amishman, Adin Yutzy, paid a large fine, sold his farm, and moved to Wisconsin to get away from 'school trouble.' When Wisconsin began prosecuting the Amish for not sending their ninth-grade children to public high school, the Yutzy family moved to Missouri."1359 In 1965, the national media carried pictures of Amish children in Iowa scrambling through cornfields to escape sheriff's deputies who had come to the Amish school to remove the pupils to the town school. ${ }^{1360}$

1348. Keim, From Erlanbach to New Glarus, in COMPULSORY EDUCATION AND THE AMISH 1, 14 (A. Keim ed. 1975).

1349. J. HosteTLER \& G. HUNTINGTON, supra note 1346, at 34.

1350. Id. at 71.

1351. Wisconsin v. Yoder, 406 U.S. 205, 208-09 n.3 (1972).

1352. Kirk, The Amish Case, NATL. REv., July 7, 1972, at 747.

1353. Keim, A Chronology of Amish Court Cases, in Compulsory Education, supra note 1348 , at 93.

1354. Keim, supra note 1348, at 14-15; Keim, supra note 1353, at 94, 96; Note, The Right Not to Be Modern Men: The Amish and Compulsory Education, 53 VA. L. REv. 925, 941-42 (1967).

1355. Keim, supra note 1353 , at $94-96$.

1356. Gingerich v. State, 226 Ind. 678,83 N.E.2d 47 (1948).

1357. J. HOSTETLER \& G. HUNTINGTON, supra note 1346, at 103.

1358. State v. Garber, 197 Kan. 567, 419 P.2d 896 (1966), appeal dismissed, 389 U.S. 51 (1967).

1359. J. HosteTler \& G. HUNTINGTON, supra note 1346, at 98.

1360. NeWSWEEK, Dec. 6, 1965, at 38; U.S. News \& WoRLD REP., Dec. 6, 1965, at 15. See generally J. HOSTETLER \& G. HUNTINGTON, supra note 1346, at 97-98. 
Some states simply left the Amish alone; ${ }^{1361}$ others - including Indiana, Iowa, Kansas and Pennsylvania - made compromise settlements with them. ${ }^{1362}$ In Ohio, law enforcement officers desisted when public support for continued prosecutions was less than they had hoped. ${ }^{1363}$ However, the dominant response of the Amish was to withdraw in the face of legal opposition. When it was not possible to have their own schools, they moved to other states and even to Canada and Central and South America. ${ }^{1364}$ Just prior to the Supreme Court's 1972 decision in Wisconsin v. Yoder, ${ }^{1365}$ the leading chronicler of the Amish saga concluded that "[i]n the United States the Old Order Amish are granted a tenuous permission, revokable virtually at the whim of the state superintendents, to maintain their own schools."1366 The Court's ruling ended this. It recognized that "[f]orced migration of religious minorities was an evil that lay at the heart of the Religious Clauses," 1367 and remedied this situation by constitutionally removing a serious danger "to the continued existence of an ancient religious faith."1368

\section{Financial Aid to Parochial Schools}

For two reasons, it is impossible to calculate the full extent to which the series of Supreme Court decisions commencing with Lemon v. Kurtzman in 1971,1369 which prohibited most allocations of public funds for church-related elementary and secondary education, have secured the "personal constitutional right not to be taxed for the support of a religious institution."1370 First, recent opinions make painfully clear that the line between permissible and forbidden public expenditures is at best hazy. ${ }^{1371}$ Second, there is no reliable way even to esti-

1361. J. HosteTler \& G. HUNTINGTON, supra note 1346, at 99.

1362. Wisconsin v. Yoder, 406 U.S. 205, 208-09 n.3 (1972).

1363. J. HOSTETLER \& G. HUNTINGTON, supra note 1346, at 103.

1364. Id. at 104.

1365. 406 U.S. 205 (1972).

1366. J. HosteTLER \& G. HUNTINGTON, supra note 1346, at 104.

1367. Yoder, 406 U.S. at 218 n.9.

1368. 406 U.S. at $218 \mathrm{n} .9$.

1369. 403 U.S. 602 (1971). See also Wolman v. Walter, 433 U.S. 229 (1977); Meek v. Pittenger, 421 U.S. 349 (1975); Marburger v. Public Funds for Pub. Schools, 417 U.S 961 (1974); Committee for Pub. Educ. \& Religious Liberty v. Nyquist, 413 U.S. 756 (1973); Levitt v. Committee for Pub. Educ. \& Religious Liberty, 413 U.S. 472 (1973); Sloan v. Lemon, 413 U.S. 825 (1973).

1370. Flast v. Cohen, 392 U.S. 83, 114 (1967) (Stewart, J., concurring). See generally Choper, The Establishment Clause and Aid to Parochial Schools, 56 CALIF. L. REv. 260 (1968). 1371. See Committee for Pub. Educ. \& Religious Liberty v. Regan, 444 U.S. 646 (1980); Wolman v. Walter, 433 U.S. 229 (1977); see also Choper, The Religion Clauses of the First Amendment: Reconciling the Confict, 41 U. PITT. L. REV. 673, 679-81 (1980). 
mate how many tax dollars would have been used to aid parochial schools had the Court not ruled as it did. Nonetheless, the existing evidence from which inferences may be drawn reveals that the cases have greatly served the individual liberty at issue.

In 1970, more than ten percent of all children in the United States (approximately 6.5 million students) attended nonpublic schools and ninety-three percent of these went to church-related institutions. ${ }^{1372}$ The highest concentrations were found in those states - e.g., New York (19\%), Pennsylvania (19\%), Ohio (15\%), Providence, R.I. $(30 \%)^{1373}$ - that had recently adopted substantial programs of public assistance. In all, as of 1971 (the year of the Lemon decision) over three-quarters of the states - as well as their subdivisions and the national government - provided some form of aid to nonpublic education totalling $\$ 650,000,000$ annually. ${ }^{1374}$ Because the Court's uncertain interpretation of the first amendment's prohibition against laws respecting an establishment of religion has not interdicted all forms of public assistance for parochial school pupils, not all of these expenditures abridged the individual constitutional right to be free of compulsory support of sectarianism. For example, about $\$ 50,000$ of the 1971 appropriations was for transportation, ${ }^{1375}$ a type of expenditure held permissible by the Justices. ${ }^{1376}$ However, the majority of the taxfunded programs in 1971 - such as purchase of secular services, teacher salary supplements, tax benefits, equipment grants, and administrative service reimbursements ${ }^{1377}$ - could no longer be undertaken.

Of much greater importance in terms of impact, however, are the possible amounts that might well have been paid in the indefinite future in the absence of the Court's rulings. Although substantial public support for church-related elementary and secondary education was a very recent development, ${ }^{1378}$ it promised to increase dramatically. For example, in 1971-1972 alone, over 100 proposals were introduced in the House of Representatives just to provide some form of tax relief to

1372. See D. Sullivan, Public Aid to Nonpublic Schools 17 (1974); Brief for Appellee at 10, Lemon v. Kurtzman, 403 U.S. 602 (1971) [hereinafter cited as Brief for Appellee].

1373. See D. SullivaN, supra note 1372, at 19; Supplement A to Brief for Appellee, supra note 1372 , at S-14.

1374. See D. Sullivan, supra note 1372 , at $92-93$.

1375. Id. at 93.

1376. See Everson v. Board of Educ., 330 U.S. 1 (1947).

1377. See D. Sullivan, supra note 1372, at 93.

1378. See Lemon, 403 U.S. at 630 (Douglas, J., concurring); Walz v. Tax Commn., 397 U.S. 664, 714 (1970) (Douglas, J., dissenting). 
parents of parochial school children. ${ }^{1379}$ An analysis of one of these plans showed an annual cost to the federal treasury of $\$ 350,000,000 .{ }^{1380}$ As an example of the scope of activity at the state level, as of 1970, about six states had already enacted purchase of services programs similar to those of Pennsylvania and Rhode Island invalidated in Lemon and more than a dozen additional states were actively considering such plans. ${ }^{1381}$ Another ten states had either passed or proposed a system of tuition grants or tax credits. ${ }^{1382}$

The sum total of future public expenditures in violation of individual constitutional rights is obviously incalculable but just as obviously, substantial. Moreover, the Justices' most recent pronouncement on the subject ${ }^{1383}$ may open up "a whole new ball game for aid to parochial schools"1384 - perhaps making the grant of "large amounts . . . just a matter of form." 1385 Nonetheless, the fragmentary data above demonstrates a gigantic potential for financial support that seemingly will not be fully realized because of the Court's intervention.

\section{F. Sexual Conduct: Abortion}

Few decisions of the Supreme Court have invalidated as many state regulations as those dealing with the constitutional right to abortion. As recently as 1967, just six years before the foundation ruling in Roe v. Wade, ${ }^{1386}$ no state in the nation permitted an abortion except to save the life of the mother. ${ }^{1387}$ By 1973, in response to positions espoused by several national professional groups (including both the American Medical Association and the American Bar Association) and to a rapidly growing public attitude favoring liberalized abortion, ${ }^{1388}$ four states - Alaska, Hawaii, New York, and Washington -

1379. See Hearings on H.R. 16141 and Other Pending Proposals Before the Comm. on Ways and Means, 92d Cong., 2d Sess. 4 (1972).

1380. See D. Sullivan, supra note 1372 , at 101.

1381. See Brief for Appellee, supra note 1372, at 35; see also Comment, Constitutional Law: State Aid to Parochial Schools - Excessive Entanglement Revisited, 24 U. FLA. L. REV. 378, 38384 (1972).

1382. See Brief for Appellee, supra note 1372, at 35. This count does not include New York, whose 1972 statutes were struck down in Nyquist, 413 U.S. 756, or Illinois, whose 1971 legislation was modified after Lemon was handed down. See Sutor, Illinois Probes the State Aid Question, 126 AMERICA 84 (Jan. 29, 1972).

1383. Mueller v. Allen, 463 U.S. 388 (1983).

1384. J. Choper, Y. Kamisar \& L. Tribe, The Supreme Court: Trends and DevelOPMENTS 1982-1983, at 53 (1984).

1385. Id.

1386. 410 U.S. 113 (1973).

1387. See Note, Abortion: The Five-Year Revolution and Its Impact, 3 EcologY L.Q. 311, 313 (1973).

1388. See id. at 317-18. 
enacted statutes that effectively legalized abortion on request and twelve other jurisdictions followed the Model Penal Code's proposal to authorize therapeutic abortions for the mental health as well as for the life or physical health of the pregnant woman. ${ }^{1389}$ Indeed, California might well be classed in the most lenient group - at least for those women who could afford a psychiatric opinion attesting to the emotional damage that childbirth would bring. ${ }^{1390}$

On the other side of the spectrum, the laws of five states - Connecticut, Louisiana, Massachustts, New Jersey, and Pennsylvania prohibited abortions under all circumstances (although there were mitigating court rulings in each jurisdiction), and about half the states continued to follow the traditional pattern by allowing an abortion only to preserve the mother's life - Mississippi extending its exception to pregnancies caused by rape. ${ }^{1391}$ Even many of the permissive statutes limited abortions to a period of gestation which fell short of that prescribed by the Justices in Roe. ${ }^{1392}$ A substantial majority of these more tolerant jurisdictions also imposed residency requirements and other sundry restrictions on abortions ${ }^{1393}$ that were struck down by the Court in the companion case to Roe, Doe v. Bolton. ${ }^{1394}$ In the subsequent decision of Planned Parenthood v. Danforth, ${ }^{1395}$ the Court invalidated additional barriers to abortion that existed in about fifteen states, ${ }^{1396}$ such as the need for spousal consent and for parental consent in the case of an unmarried minor. The Danforth ruling also rejected the express or implied prohibition of five jurisdictions against use of the saline amniocentesis method of abortion. ${ }^{1397}$ Finally, in Colautti v. Franklin, ${ }^{1398}$ the Justices cast a considerable cloud on the validity of statutes in approximately one-third of the states ${ }^{1399}$ that

1389. See id. at $313-14,345$.

1390. See Moyers, Abortion Laws: A Study in Social Change, 7 SAN Diego L. Rev. 237, 241 (1970); Comment, Roe- Doe- Where Are You?: The Effects of the Supreme Court's Abortion Decisions, 7 U.C.D. L. REv. 432, 440-41, 445 (1974).

1391. See Note, supra note 1387 , at $314,345$.

1392. See id. at $314,346$.

1393. For example, restrictions commonly included a requirement that abortions be performed in a hospital licensed by the state or approved by the Joint Commission on Accreditation of Hospitals, or concurred in by a second physician or hospital staff committee. See id. at 315, 346.

1394. 410 U.S. 179 (1973).

1395. 428 U.S. 52 (1976).

1396. See Note, Abortion Statutes after Danforth: An Examination, 15 J. FAM. L. 537, 55658 (1976-77).

1397. See id. at 548-49.

1398. 439 U.S. 379 (1979).

1399. See Alan GutTMacher Institute, Planned Parenthood Fedn. of America, Abortion 1974-1975: Need \& Services in the United States, Each State \& Metro- 
oblige doctors who perform abortions to take measures to preserve the life and health of the fetus if it appears to be viable.

The consequences for individuals, while not precisely calculable, have, nonetheless, been momentous. As a statistical matter, the number of reported legal abortions in the United States has grown from an estimated 50,000 in $1969^{1400}$ (before New York's reform) to just under 600,000 in $1972^{1401}$ (the final pre-Roe year) to nearly $1,000,000$ in $1976^{1402}$ and over $1,500,000$ in $1980.1^{1403}$ This phenomenon has several ramifications.

First, although estimates of criminal abortions prior to Roe and Doe vary drastically (ranging from 48,000 to $1,200,000$ annually), ${ }^{1404}$ there is no doubt that their number has decreased sharply. Perhaps seventy percent of legal abortions would have been performed illegally otherwise. ${ }^{1405}$ While liberalization has by no means eliminated all inept and malign abortion services, ${ }^{1406}$ the fact remains that the risk of death from an illegal abortion is twelve times greater than from a legal one $\mathrm{1}^{\mathbf{4 0 7}}$ and that mortalities resulting from abortion have diminished markedly. ${ }^{1408}$ Nationally, although it has been asserted that 8,000 women were killed each year in criminal abortions, ${ }^{1409}$ more conservative estimates prior to the advent of reform in 1967 placed the figure at between 250 and 500.1410 From 1968 to 1970, an average of fifty-seven women died annually from illegal abortions; ${ }^{1411}$ the figures subsequent

POLITAN AREA, app. III, at 122-23 (1976), reprinting A Review of State Abortion Laws Enacted Since January, 1973, 4 FAM. PLAN./POP. REP. 108 (1975) [hereinafter cited as GuTTMACHER INSTITUTE]; Note, supra note 1396, at 563-66.

1400. Tietze, The Effect of Legalization of Abortion on Population Growth and Public Health, in GUTTMACHER INSTTUTE, supra note 1399, app. I, at 110, 111.

1401. GUTTMACHER INSTITUTE, supra note 1399, at 7.

1402. Center for Disease Control, Abortion Surveillance 1976, at 1 (1976) [here-

inafter cited as ABORTION SURVEILIANCE 1976].

1403. N.Y. Times, Feb. 23, 1982, at A14, col. 6.

1404. See Louisell \& Noonan, Constitutional Balance, in The Morality OF ABORTION 220, 241-43 (J. Noonan ed. 1970); Lucas, Federal Constitutional Limitations on the Enforcement and Administration of State Abortion Statutes, 46 N.C. L. REv. 730 (1968).

1405. Tietze, supra note 1400 , at 110 .

1406. See Chicago Sun-Times, The Abortion Profiteers (Special Reprint 1978).

1407. Tietze, supra note 1400 , app. I, at 111.

1408. In New York, whereas maternal death from criminal abortions comprised nearly half of all maternal mortalities in 1961, only one such death was recorded in the first six months under the liberalized regime. See Pakter \& Nelson, Abortion in New York City: The First Nine Months, FAM. Plan. Persp., July 1971, at 5, 10. In California, death from illegal abortions declined from 27 in 1960 to none in 1976. See DeParTMENT OF HEALTH SERvices, CaliforNia Health and Welfare Agency, Abortion in California, 1968-76, at 52 (table 71).

1409. Louisell \& Noonan, supra note 1404, at 231.

1410. See id. at 231-32.

1411. See Tietze, supra note 1400 , app. I, at 112 (table 1). 
to Roe were nineteen in 1973 , six in 1974 , four in 1975 , three in 1976 , seven in 1978, none whatever in 19791412 and one in $1980.1413 \mathrm{Be}$ tween 1976 and 1980 less than twenty maternal deaths annually were associated with legally induced abortions. ${ }^{1414}$

Apart from mortalities, since legal abortions are indisputably safer than criminal ones, an untold number of women have also avoided being permanently maimed, becoming sterile, or suffering other serious illness as a result of the Court's mandate. Further, since it is generally agreed that the availability of lawful abortions will result in most being performed in the early stages of pregnancy, and since medical complications from abortion vary directly with the gestation period, all statistics imply a lower complication rate as the product of legalization. ${ }^{1415}$

Second, the Court's recognition of an individual's constitutional right to an abortion has meant that a great many women, either unwilling or afraid to violate the law, have been able to forego unwanted pregnancy and childbirth. Whereas over 1,000,000 women who sought an abortion in 1973 could not obtain one, by 1977 this figure had been reduced by nearly fifty percent. ${ }^{1416}$ This has resulted in substantial benefits for maternal life and physical health since it has been found anywhere from four to eight times more dangerous for a woman to complete a pregnancy than to have a legal abortion..$^{1417}$ Indeed, in 1976 there were nearly fifteen times more deaths per 100,000 births than per 100,000 legal abortions. ${ }^{1418}$ The extent to which undesired

1412. Abortion Surveillance, 1976, supra note 1402, at 9; Center for Disease Control, Annual Summary 1980: Reported Morbidity \& Mortality in the United States, 29 MoRBiDITY \& MORTALITY WEEKIY REP., Sept. 1981, at 104 [hereinafter cited as Morbidity and Mortality].

1413. Center for Disease Control, Abortion Surveillance 1979-1980, at 12 (1983) [hereinafter cited as ABortion SURVEILLANCE, 1979-1980].

1414. ABortion SurVeillaNCE, 1976, supra note 1402, at 48 (10 in 1976); Morbidity and Mortality, supra note 1412, at 104 (17 in 1977, 11 in 1978, 20 in 1979); ABORTION SURVEILLANCE, 1979-1980, supra note 1413, at 10 (8 in 1980).

1415. See Note, supra note 1387, at 338-39. For example, the number of women admitted to New York hospitals for abortion-related affictions was cut in half between 1969 and 1973; see also Cates, Legal Abortion: Are American Black Women Healthier Because of It?, 38 PHYLON 267, 272-80 (1977).

1416. See Forrest, Tietze \& Sullivan, Abortion in the United States, 1976-1977, 10 FAM. Plan. Persp. 271 (1978) [hereinafter cited as Forrest, 1976-1977].

1417. See Lamm \& Davison, Abortion Reform. YALe Rev. L. \& Soc. Acrion, Spring 1971, at 55, 56; Tietze, supra note 1400 , app. I, at 111 .

1418. Forrest, 1976-1977, supra note 1416, at 275-76. Statistics from 1977 show 11.2 maternal deaths per 100,000 births, 2 Public Health SERvice, U.S. DEPT. OF Health AND Human SeRv., Vital Statistics of the UNITEd States I-73, 74 (1981), and 1.4 maternal deaths per 100,000 legal abortions, CENTER FOR DisEASE CONTROL, ABORTION SURVEILLANCE, 1977, at 1 (1979) [hereinafter cited as ABORTION SURVEILLANCE, 1977]. After New York removed its prohibition, maternal mortality associated with childbirth fell nearly $60 \%-$ "[t]he most logical explanation for this dramatic improvement in public health is that a large 
pregnancies and children impair the mental health and stability of mothers and their families is less ascertainable, but psychiatric studies attest to the general phenomenon. ${ }^{1419}$ And the existence of children with mutilated minds and bodies attributable to such causes as thalidomide and rubella ${ }^{1420}$ strongly indicate these problems, too, have been greatly relieved.

Finally, by making legal abortions obtainable throughout the country, the Court's rulings have significantly eased the burden, peril, and expense of obtaining one. In 1972, forty-four percent of all women who received lawful abortions were forced to travel outside their state of residence to do so, ${ }^{1421}$ thus frequently delaying the procedure "to a later and riskier period of gestation. Distance also makes rapid diagnosis and treatment of any post-abortion complications difficult."1422 By 1977, under ten percent of the pregnant women were so encumbered ${ }^{1423}$ (though about twenty-five percent did have to go to another county within their state), ${ }^{1424}$ and the figure dropped to $7.4 \%$ in $1980 .{ }^{1425}$

It is still impossible to know at this time the full extent to which the Court's more recent decisions in Maher v. Roe, ${ }^{1426}$ and Harris $v$. $M c R a e, 1427$ which permitted the government to withold Medicaid benefits from indigent women for both elective and therapeutic abortions, will diminish the impact of Roe v. Wade and its earlier progeny. In 1976, nearly one-third of all legal abortions were financed by Medicaid, ${ }^{1428}$ and within just over a year of Maher, only sixteen jurisdic-

number of abortions are being performed on women in high-risk age and health groups, thus significantly lowering childbirth fatality." Note, supra note 1387, at 341.

1419. See studies cited in Comment, supra note 1390, at 441 n.47.

1420. Niswander, Medical Abortion Practices in the United States, 17 CASE W. RES. L. REv. 403,412 (1965) (30,000 rubella-affected babies born in the United States during the 1964 rubella epidemic).

1421. Abortion SurveillanCE, 1976, supra note 1402, at 40.

1422. Forrest, 1976-1977, supra note 1416, at 273 (footnote omitted).

1423. ABortion SuRveillance, 1977, supra note 1418, at 30 (6.5\%); Forrest, Tietze \& Sullivan, Abortion in the United States, 1977-1978, 11 FAM. PLAN. PERSP. 329, 332 (1979) (9\%) [hereinafter cited as Forrest, 1977-1978].

1424. See Forrest, 1976-1977, supra note 1416, at 271; Forrest, 1977-1978, supra note 1423, at 330 .

1425. ABortion SurveillaNCE, 1979-1980, supra note 1413, at 4. Similarly, in 1970, after California and New York had removed their barriers to abortion but before the Justices mandated this system for the nation, $81 \%$ of all legal abortions performed in the United States took place in those two states (where only approximately one-fifth of ail women between the ages of 15 and 44 lived. Forrest, 1976-1977, supra note 1416, at 272.). ABORTION SURVEILLANCE, 1976, supra note 1402, at 2. By 1976 and 1977, this number had fallen to below 30\%. Id., at 1-2; Morbidity and Mortality, supra note 1412, at 103 (27.5\% in 1979).

1426. 432 U.S. 464 (1977).

1427. 448 U.S. 297 (1980).

1428. 35 CONG. Q. WKLY. REP. 1199,1200 (1977). 
tions continued to pay for all or most abortions for poor women. ${ }^{1429}$ In some "states where medicaid dollars have been cut off, the impact on abortion services has been dramatic. In Arkansas, for example, the number of abortions paid for by these funds has dropped from 500 in 1976 to 5 during the period of August 1977 to June 1978; in South Carolina from 1,400 to 14; in Texas from 13,300 to 59."1430 Although there is no doubt that many indigent women resigned themselves to completing their pregnancies and that "through its monitoring system," the Center for Disease Control "linked four deaths of indigent women from illegal or self-induced abortions to the unavailability of Medicaid financing,"1431 many others managed to gain assistance without reverting "to dangerous back-alley or coat-hanger abortions." 1432 Some county governments granted funds despite their elimination by the state. ${ }^{1433}$ Many private clinics either reduced their fees or abandoned them altogether ${ }^{1434}$ and "[s]ome large metropolitan public hospitals in non-funded states [continued] to provide inexpensive legal abortion services for their low-income patient populations." 1435 While private physicians often declined to provide services without assurance of their fees, ${ }^{1436}$ a number have been willing to make special arrangements for payment. ${ }^{1437}$ Moreover, "[s]everal private family planning agencies and philanthropic donors have established funding sources to finance legal abortions for women who otherwise could not afford them."1438 Once again, a growing number of women pursued the riskier and burdensome route of crossing state lines to satisfy their needs - an estimated 2,000 from Maine alone in less than a year after Maher. ${ }^{1439}$ Thus, in mid-1978, it was reported

1429. U.S. NEWS \& WORLD REP., July 24, 1978, at 63.

1430. Id.

1431. Trussell, Menken, Lindheim \& Vaughan, The Impact of Restricting Medicaid Financing for Abortion, 12 FAM. PLAN. Persp. 120, 121 (1980) [hereinafter cited as Trussell].

1432. NEWSWEEK, Feb. 6, 1978, at 32.

1433. Id.

1434. "For example, the Cullen Women's Center in Houston, Tex., where more than half the women requesting abortion services cannot pay, has spent $\$ 15,500$ for abortions that used to be covered by public-assistance funds." U.S. NEWS \& WORLD REP., July 24, 1978, at 63. See also NEWSWEEK, Feb. 6, 1978, at 32.

1435. Gold \& Cates, Restriction of Federal Funds for Abortion: 18 Months Later, 69 AM. J. Pub. HeAlTH 929, 930 (1979). "[F]or example, Grady Memorial Hospital in Atlanta performed about the same number of legal abortions to terminate pregnancies up through 12 weeks gestation after the funding restriction in Georgia, as it had before." Id.

1436. See Digest, 10 Fam. Plan. Persp. 359, 362 (1978).

1437. See NEwSwEEK, Feb. 6, 1978, at 32. See also Rubin, Gold \& Cates, Response of Low Income Women and Abortion Facilities to Restriction of Public Funds for Abortion: A Study of a Large Metropolitan Area, 69 AM. J. PUB. HealTr, 948-50 (1979).

1438. Gold \& Cates, supra note 1435, at 930.

1439. NEWSWEEK, Feb. 6, 1978, at 32. 
that Maher's adverse consequences to women's abortion rights were still relatively limited in that "70 percent of all medicaid-supported abortions are performed in a few major states such as New York, California and Pennsylvania, and up until now these states have continued liberal funding." 1440 In early 1979, a survey disclosed that eighty-five percent of Medicaid-eligible women "resided in states that were providing public funds for abortion, albeit not using federal funds."1441 In late 1979, "10 states and the District of Columbia had enacted laws or established policies to pay for all or most of the abortions of Medicaid-eligible women, and another 12 states are under court order to do so" - thus accounting for ninety percent of the Medicaid abortions previously performed. ${ }^{1442}$ More precise figures from varied localities tend to confirm these projections. 1443 Overall, although "almost no federally financed abortions were performed" during the two and onehalf years beginning in mid-1977 after the Hyde Amendment went into effect, "an estimated $94 \%$ of pregnant, low-income women 'at risk' obtained a legal abortion, $65 \%$ with State funds and $29 \%$ with other sources of funding." 1444

Because the liberalizing statutory trend began several years before the Burger Court's abortion rulings in 1973, not all the imposing developments that have since occurred may be fairly attributed to the Justices' intervention. However, especially because of the many hostile state legislative reactions, it is equally fair to conclude that Roe $v$. Wade greatly hastened the drive toward abortion legalization and dramatically affected the lives and liberties of an enormous number of women. ${ }^{1445}$ It is this impact of the Supreme Court's abortion decisions, rather than the question of whether as a matter of substantive

1440. U.S. NEWS \& WORLD REP., July 24,1978 , at 63.

1441. Gold \& Cates, supra note 1435 , at 930.

1442. Forrest, 1977-1978, supra note 1423, at 340-41.

1443. Whereas about 295,000 eligible women obtained publicly funded abortions in 1977 (the year prior to the Court's validation of the new restrictions), the number for 1978 decreased by only about one-third to 194,000. Gold, After the Hyde Amendment: Public Funding for Abortion in FY1978, 12 Fam. Plan. Persp. 131, 133 (1980). Specific "[r]ecent studies indicate that despite cut-off of both federal and state funds, the rate of abortions in 1978 among Medicaideligible women in Texas was 65 percent of 1977 Medicaid abortions, the rate in Ohio 77 percent of 1977 Medicaid abortions, and the rate in Georgia 82 percent of 1977 Medicaid abortions." Regan, Supreme Court Roundup: 1979 Term, 55 Thought 487, 492 (1980). For details, see Trussell, supra note 1431, at 127-28; Rubin, Gold \& Cates, supra note 1437, at 948. A more limited survey in Hartford, Connecticut disclosed that $63 \%$ of indigent women desirous of a legal abortion managed to obtain one, see Women's Health Servs., Inc. v. Maher, 482 F. Supp. 725, 731 (D. Conn.), vacated, 636 F.2d 23 (2d Cir. 1980), and an inquiry in Maricopa County, Arizona concluded that funding restrictions had no appreciable effect on the abortion rate, Survey of Abortion Law, 1980 ARIZ. ST. L.J. 67, 213 (1980).

1444. ABORTION SURVEILlANCE, 1979-1980, supra note 1413, at 15.

1445. Unquestionably, opponents of abortion who focus on the rights of the child rather than on those of the woman have a markedly different perspective on whether the Court's decisions 
constitutional doctrine the Court overstepped its proper bounds, that is the critical issue here. The longevity of the decisions' effect, as we have seen, is highly uncertain at present, particularly because the issue of public funding for the indigent is in such a state of flux - a matter further complicated by the series of cases on state constitutional grounds, that have reached a conclusion opposite to that of the Supreme Court in Maher and Harris. ${ }^{1446}$ However, even if the statistical increases are reversed and eventually return to near their original position, the powerful consequences for women's personal liberty that have already taken place cannot be undone.

\section{G. Just Compensation}

It has long been undisputed that if government "takes" private property for public use - by actual appropriation or physical invasion $^{1447}$ (or regulatory action designed to facilitate such subsequent appropriation or invasion ${ }^{1448}$ ) - the fifth amendment's requirement of just compensation, applicable to states through the fourteenth amendment, ${ }^{1449}$ entitles the injured property owner to money damages. However, although it was equally clear that government action which imposed oppressive economic burdens on private property by limiting or requiring its use could also constitute a "taking" even though adopted for regulatory purposes, ${ }^{1450}$ prior to 1981 the question of whether this type of "taking" also entitled the owner to monetary compensation remained unresolved. In modern times, the principal species of such legislation has been zoning and similar land use regulations, but its wide range of diversity may be illustrated by an ambulance permit provision requiring that the licensee respond to "any emergency call, whether initiated by the police or fire department or a private individual,"1451 irrespective of any promise to pay for the service.

were beneficial to individual liberty. However, in this instance and for the present, the Court has defined individual liberty as the woman's right. See text at notes 27-28 supra.

1446. See, e.g., Committee to Defend Reproductive Rights v. Myers, 29 Cal. 3d 252, 625

P.2d 779, 172 Cal. Rptr. 866 (1981); Doe v. Maher, [1981-1982] 8 FAM. L. REP. (BNA) 2006

(Conn. Super. Ct. 1981); Moe v. Secretary of Admin. \& Fin., 382 Mass. 629, 417 N.E.2d 387

(1981); Right to Choose v. Byrne, 91 N.J. 287, 450 A.2d 925 (1982).

1447. United States v. Causby, 328 U.S. 256 (1946); Pumpelly v. Green Bay Co., 80 U.S. (13 Wall.) 166 (1871).

1448. See, e.g., Richmond Elks Hall Assn. v. Richmond Dev. Agency, 561 F.2d 1327 (9th

Cir. 1977).

1449. Chicago, B. \& Q.R.R. v. City of Chicago, 166 U.S. 226, 241 (1897).

1450. Penn Cent. Transp. Co. v. New York City, 438 U.S. 104, 127-28 (1978).

1451. Mountain Med., Inc. v. City of Colorado Springs, 43 Colo. App. 391, 608 P.2d 821, 823 (1979). 
Several state supreme courts had authoritatively ruled that unduly severe exercises of state regulatory power do permit the victimized property owner to bring an "inverse condemnation" action for money damages. ${ }^{1452}$ A number of others, including California and New York, ${ }^{1453}$ however, had reached the opposite conclusion, holding that "[i]f the legislative body acts wrongfully in its legislative capacity the judicial remedy is the undoing of the wrongful legislation and not money damages."1454 Although most states had no clearly established view on the matter, ${ }^{1455}$ the trend - understandably supported by state and local government agencies that feared extensive financial liability resulting from any judicial invalidations of their land use plans - appeared to favor the restrictive approach of California and New York, at least in the absence of extreme circumstances. ${ }^{1456}$ Indeed, a federal court of appeals said that, as of 1980, its "research has disclosed no case in which a federal court has ordered a state or local government unit to pay for a diminution of the value of a piece of property caused by a zoning regulation." 1457

In San Diego Gas \& Electric Co. v. City of San Diego, 1458 a majority of the Justices indicated that they rejected the California-New York position, ${ }^{1459}$ reasoning that

1452. See, e.g., Lomarch Corp. v. Mayor \& Common Council of Englewood, 51 N.J. 108, 237 A.2d 881 (1968); Austin v. Teague, 570 S.W.2d 389 (Tex. 1978); see also Ventures in Property I v. City of Wichita, $225 \mathrm{Kan} .698,594$ P.2d 671 (1979); Willoughby Hills v. Corrigan, 29 Ohio St. 2d 39, 278 N.E.2d 658 (1972); cf. State v. Mayhew Prods. Corp., 204 Neb. 266, 281 N.W.2d 783 (1979).

1453. Agins v. City of Tiburon, 24 Cal. 3d 266, 598 P.2d 25, 157 Cal. Rptr. 372 (1979), affd., 447 U.S. 255 (1980); Fred F. French Investing Co. v. City of New York, 39 N.Y.2d 587, 350 N.E.2d 381, 385 N.Y.S.2d 5, appeal dismissed, 429 U.S. 990 (1976); Charles v. Diamond, 41 N.Y.2d 318, 360 N.E.2d 1295, 392 N.Y.S.2d 594 (1977); Jensen v. City of New York, 42 N.Y.2d 1079, 369 N.E.2d 1179, 399 N.Y.S.2d 645 (1977).

1454. Davis v. Pima County, 121 Ariz. 343, 345, 590 P.2d 459, 461 (Ct. App. 1978), cert. denied, 442 U.S. 942 (1979); see also Mountain Med., Inc. v. City of Colorado Springs, 43 Colo. App. 391, 608 P.2d 821 (1979); Gold Run Ltd. v. Board of County Commrs., 38 Colo. App. 44, 554 P.2d 317 (1976).

1455. For conflicting intimations in Florida, see Mailman Dev. Corp. v. City of Hollywood, 286 So. 2d 614 (Fla. Dist. Ct. App. 1973), cert. denied, 419 U.S. 844 (1974); Askew v. Gables-bythe-Sea Inc., 333 So. 2d 56 (Fla. Dist. Ct. App. 1976), cert. denied, 345 So. 2d 420 (Fla. 1977).

1456. See, e.g., DeMello v. Town of Plainville, 170 Conn. 675, 368 A.2d 71 (1976); Holaway v. City of Pipestone, 269 N.W.2d 28 (Minn. 1978); Eck v. City of Bismarck, 283 N.W.2d 193 (N.D. 1979); see also Gary D. Riehart, Inc. v. Township of Carroll, 487 Pa. 461, 409 A.2d 1167 (1979).

1457. Pamel Corp. v. Puerto Rico Highway Auth., 621 F.2d 33, 35 (1st Cir. 1980) (footnote omitted).

1458. 450 U.S. 621 (1981).

1459. The opinion of the Court did not reach this issue. The matter was addressed by Justice Brennan, joined by Justices Stewart, Marshall and Powell, in dissent. 450 U.S. at 647-60. Justice Rehnquist joined the Court's opinion but added that he "would have little difficulty agreeing with much of what is said" on this issue in Justice Brennan's dissenting opinion. 450 U.S. at 63334. Further, it is fair to infer from other recent decisions on the subject that most of the remain- 
once a court establishes that there was a regulatory "taking," the Constitution demands that the government entity pay just compensation for the period commencing on the date the regulation first effected the "taking," and ending on the date the government entity chooses to rescind or otherwise amend the regulation.

. . . Invalidation unaccompanied by payment of damages would hardly compensate the landowner for any economic loss suffered during the time his property was taken. ${ }^{1460}$

Although the full scope of what constitutes a "regulatory taking" remains to be determined, ${ }^{1461}$ the consequences of this constitutional requirement of "interim damages" are obviously substantial. Although most of the leading appellate decisions do not reach the issue of detailed calculation of monetary relief, 1462 those that contain such data illustrate the potential injury that may be rectified by the Court's rule. ${ }^{1463}$

Unlike those decisions in which the trial court's finding of uncon-

ing Justices share this view. See, e.g., Kaiser Aetna v. United States, 444 U.S. 164 (1979) (opinion of the Court joined by Burger, C.J., and Stewart, White, Powell and Stevens, JJ.); Penn Cent. Transp. Co. v. New York City 438 U.S. 104, 138-53 (1978) (dissenting opinion joined by Burger, C.J. and Stevens, J.).

For recent lower court decisions interpreting San Diego Gas \& Electric as establishing this rule, see Hernandez v. City of Lafayette, 643 F.2d 1188, 1199-200 (5th Cir. 1981), cert. denied, 455 U.S. 907 (1982); Burrows v. City of Keene, 121 N.H. 590, 599, 432 A.2d 15, 20 (1981). But cf. Hernandez v. Lafayette, 643 F.2d 1188 (5th Cir. 1981), cert. denied, 455 U.S. 907 (1982) ("taking" may not commence until some "reasonable time" after zoning regulation is enacted).

1460. 450 U.S. at 653-55 (Brennan, J., dissenting) (footnotes omitted).

1461. For limiting applications of the doctrine despite dicta suggesting broader potential, see Penn Cent. Transp. Co. v. New York City 438 U.S. 104 (1978); Agins v. City of Tiburon, 447 U.S. 255 (1980). One can only speculate about the extent to which the Justices' views in the San Diego Gas \& Electric case were affected by the fact that the city had first proposed a bond issue for funds to acquire the company's realty for preservation as parking and then, after the voters disapproved the bond issue, continued to zone the property as "open space area." 450 U.S. at 625 .

1462. For example, in Lomarch Corp. v. Mayor \& Common Council of Englewood, the court invalidated a zoning ordinance whose effect was to impose a one-year "freeze" on any development of complainant's land. On the question of remedy for this "temporary taking," the court stated that the landowner should receive "the value of an "option' to purchase the land for the year." S1 N.J. 108, 114, 237 A.2d 881, 884 (1968).

1463. For example, in the ambulance license case, see text at note 1451 supra, during the relevant four-year period between the first application of the ordinance to the ambulance company and the state trial court's holding that it was unconstitutional, the complainants "provided ambulance services to some 6,185 individuals within the city of Colorado Springs for which they were not paid either in whole or in part. The unpaid amount totaled \$217,375.74." Mountain Med. Inc. v. City of Colorado Springs, 43 Colo. App. 391, 608 P.2d 821, 823 (1979). In the Arizona decision that established the state's adherence to the "no money damages" principle, the court invalidated the challenged zoning provision but refused to honor the aggrieved property owners' claimed damages "in the sum of $\$ 67,035$ for loss in the property value because of the delay in securing their right to build on the property and the sum of $\$ 95,180$ for the loss of an aid-in-construction agreement which would have been available had the board changed the zoning." Davis v. Pima County, 121 Ariz. 343, 345, 590 P.2d 459, 461 (Ct. App. 1978), cert. denied, 442 U.S. 942 (1979). 
stitutional regulation is affirmed on appeal, thus confining the time that the property was "taken" and limiting the resulting injury, the San Diego Gas \& Electric case illustrates how the amount of damage may be compounded by the duration of the litigation process. The challenged zoning provision, which frustrated the complainant's plan to develop its property as a nuclear power site, was enacted in 1973. Although the state trial court found a "taking" in 1976, as of 1982 there had been no final judgment on the merits, the Supreme Court in 1981 returning the case to the trial court for resolution of disputed factual issues. Indeed, under the California-New York approach, even if the trial court on remand reaffirmed its original conclusion of invalidity and this were to remain undisturbed through the state (and federal) appellate process, there would still be no guarantee that the utility company could then proceed with its construction plans. Since the regulatory agency could then simply promulgate a modified zoning provision, the property owner's only course would be to raise new legal objections to the amended ordinance. ${ }^{1464}$ While the Justices' San Diego Gas \& Electric principle prevents neither the inevitable delays of litigation nor what has come to be known as the "zoning-amendment shuffe," 1465 it does at least assure some meaningful remedy for many otherwise uncompensated constitutional injuries.

1464. As observed by Justice Brennan in his dissent in San Diego Gas and Electric:

At the 1974 annual conference of the National Institute of Municipal Law Officers in California, a California City Attorney gave fellow city attorneys the following advice:

"IF ALL ELSE FAILS, MERELY AMEND THE REGULATION AND START OVER AGAIN.

If legal preventive maintenance does not work, and you still receive a claim attacking the land use regulation, or if you try the case and lose, don't worry about it. All is not lost. One of the extra 'goodies' contained in the recent [California] Supreme Court case of Selby v. City of San Buenaventura, 10 Cal. 3d 110, [514 P.2d 111, 109 Cal. Rptr. 799 (1973)] appears to allow the City to change the regulation in question, even after trial and judgment, make it more reasonable, more restrictive, or whatever, and everybody starts over again.

....

See how easy it is to be a City Attorney. Sometimes you can lose the battle and still win the war. Good Luck." Longtin, Avoiding and Defending Constitutional Attacks on Land Use Regulations (Including Inverse Condemnation), in 38B NIMLO MUNICIPAL LAW REVIEW $192-93$ (1975) (emphasis in original).

450 U.S. at 655, n.22.

Subtle and complex issues as to the amount of interim damages - eg., whether it should be the difference between the value of the property as subject to the invalid regulation and (1) its value suject to a hypothetical constitutional regulation, or (2) its value subject to no regulation at all - are explored in Costonis, "Fair" Compensation and the Accommodation Power: Antidotes for Taking Impasse in Land Use Controversies, 75 ColUM. L. REv. 1021 (1975); Hagman, Temporary or Interim Damage Awards in Land Use Control Cases (pt. II), 4 Zoning \& PlaNnING L. REP. 137 (1981).

1465. Mytelka, Judicial Remedies, in AfTer Mount LAUREL: The New SUburban ZoNING 150, $153-54$ (J. Rose \& R. Rothman eds. 1977) (The "zoning amendment shuffle" is "the not uncommon municipal tactic of avoiding an adverse trial decision by rezoning on appeal."). 


\section{H. Equal Protection \\ 1. Racial Separation}

As of 1977, there were no published statistics describing the extent of racial imbalance in publicly assisted housing projects across the country. ${ }^{1466}$ The data that was available strongly implied, however, that government efforts to promote neighborhood integration had largely failed. Nationwide, between 1970 and 1976, blacks had "increased their share of suburban population only modestly - from 4.5 per cent to 5.1," ${ }^{1467}$ and even here it appears that the overwhelming percentage of blacks living beyond the center city ghettos resided in virtually all-black suburbs. ${ }^{1468}$ In Chicago, the site of the landmark Gautreaux ${ }^{1469}$ litigation, where 40,000 families were affected, ${ }^{1470}$ "[u]ncontradicted evidence . . . established that the public housing system operated by [the Chicago Housing Authority] was racially segregated, with four overwhelmingly white projects located in white neighborhoods and with $99-1 / 2 \%$ of the remaining family units located in Negro neighborhoods and $99 \%$ of those units occupied by Negro tenants." 1471

It may be impossible ever to determine the full impact of the Supreme Court's ruling in Hills $v$. Gautreaux ${ }^{1472}$ on racial segregation in housing, but some concrete accomplishments have occurred in its wake. First, the Gautreaux suit resulted in "an order requiring that at least 3 units of future public housing be located outside areas of minority concentration for each one constructed within a minority area throughout the metropolitan area."1473 More specifically, within two months after Gautreaux was handed down in April 1976, plaintiffs and HUD executed an agreement providing that HUD, pursuant to section 8 of the Housing and Community Development Act of $1974,{ }^{1474}$ would subsidize rents for low-income black families in privately owned apartment buildings in the predominantly white Chicago

1466. Confirmed by telephone conversations in December 1977 with HUD Regional Office in San Francisco.

1467. Maloney, Housing: Next Integration Battleground?, U.S. NEwS \& WORLD REP., Nov. 29,1976 , at 47.

1468. See A. Polikoff, Housing the Poor: The CASE for Heroism 100 (1978).

1469. Hills v. Gautreaux, 425 U.S. 284 (1976).

1470. Dillard, Rent-Aid Plan Shatters Myths, Suburban Trib (Southwest Cook County, Ill.), Nov. 28, 1977, at 1, col.3.

1471. Gautreaux, 425 U.S. at 287-88.

1472. 425 U.S. 284 (1976).

1473. Housing AFF. Letrer, Feb. 17, 1978, at 4, col. 1.

1474. Housing and Community Development Act $\S 201$ (a), 42 U.S.C. $§ 1437 F$ (1982). 
suburbs. ${ }^{1475}$ By 1979, 455 such families had been placed in apartments there or in other white areas of Chicago. ${ }^{1476}$ Although about one-fifth of these families subsequently withdrew - primarily because they decided that they did not want to live outside the central city ${ }^{1477}$ - the overwhelming majority reported "an overall improvement in their quality of life."1478

Benefits of the program for the families involved include better schools for the children, education and employment opportunities for the parents, and a living environment in which they no longer have to fear for their lives.

Benefits for taxpayers are more long range. Families on the program have been reunited because husbands who were absent from home because of welfare regulations have been able to find jobs in the suburbs, move back with their families, and get the families off the welfare rolls. ${ }^{1479}$

In mid-1981, HUD entered into a consent decree with the Gautreaux litigants, agreeing to provide some form of "assisted housing" to eligible persons in either "predominantly non-minority areas" of the Chicago metropolitan district or in minority areas "undergoing substantial physical development" until the number of occupancies equals $7,100.1480$

Beyond Chicago, the results of Gautreaux are less clearly defined. The earliest predictions regarding the effectiveness of the decision were extremely pessimistic. ${ }^{1481}$ As a matter of nationwide impact, its thrust plainly was only "to emphasize, in a general way, that housing problems were metropolitan problems, rather than actually to produce suburban housing for inner city residents." 1482 Nonetheless, a few months after the Court's verdict, it was reported that Gautreaux was a "major catalyst" in the government's "taking a tougher line on the housing-assistance plans for the poor that communities must prepare in order to get special grants from HUD. The agency is also pressuring builders and brokers to establish better sales programs to lure

1475. Letter from General Counsel, HUD to Alexander Polikoff, June 7, 1976.

1476. See K. Peroff, C. Davis \& R. Jones, Gautreaux Housing Demonstration: an Evaluation of ITs Impact on Participating Households i, 7 (U.S. Dept. of Housing and Urban Development, Office of Policy Development \& Research, Div. of Policy Studies, Dec. 1979); see also Dillard, supra note 1470, at 1.

1477. See K. Peroff, C. DAvis \& R. Jones, supra note 1476, at i.

1478. Id. at 140. See generally id. at 130-63.

1479. Dillard, supra note 1470 , at 8.

1480. See Gautreaux v. Landrieu, 523 F. Supp. 665, 672-83 (N.D. Ill. 1981), affd. sub nom. Gautreaux v. Price, 690 F.2d 616 (7th Cir. 1982).

1481. See, e.g., Welfeld, The courts and desegregated housing: The meaning (if any) of the Gautreaux case, The PUB. INTEREST, Fall 1976, at 123.

1482. A. PoLiKoff, supra note 1468 , at 92. 
black buyers." ${ }^{1483}$ In mid-1977, the HUD Assistant Secretary for Fair Housing and Equal Opportunity announced "that opening up the suburbs to low-income housing is one of the highest priorities within HUD, and that the Gautreaux ruling mandates HUD to act throughout a whole metropolitan area to deconcentrate low-income housing now predominantly in the inner cities." 1484 Several months later, a HUD task force created to implement Gautreaux proposed a new section 8 development program for metropolitan cities throughout the country fashioned on the Chicago model that grew out of Gautreaux. ${ }^{1485}$ As a result of the Justices' edict, revised regulations governing site selections for all HUD programs added three criteria that respond directly to integration goals: sites are not to be located in areas of minority concentrations (two exceptions to this rule are allowed); they must not significantly increase the proportion of minority residents in the neighborhoods; and the sites are to promote greater choices of housing but avoid undue concentrations of subsidized families in low-income areas. ${ }^{1486}$

Regardless of good intentions, however, there is a substantial gap between ambitious planning and actual problem solving. Initial statistics in 1978 disclosed that the section 8 rentals assistance program improved racial integration of neighborhoods in only one of the three sections into which the nation had been divided. ${ }^{1487}$ A later study of federally aided housing programs in the suburbs of five metropolitan areas for the period between 1975 and 1979 reveals that in only one (Minneapolis-St. Paul) had significant numbers of central city poor people moved to assisted housing in the suburbs. ${ }^{1488}$ In May 1979, when HUD invited planning agencies from the twenty-two regions of the country with the highest concentrations of urban blacks as compared to suburban whites to discuss this situation, various objections were raised. ${ }^{1489}$ Protesters from St. Louis

argued that although such a program would foster integration, it would

1483. Maloney, supra note 1467.

1484. 5 Hous. \& DEV. RPTR. No. 4, June 27, 1977, at 64.

1485. 5 Hous. \& DEV. RPTR. No. 12, Aug. 22, 1977, at 220-21.

1486. Mitchell \& Smith, Race and Housing: $A$ Review and Comments on the Content and Effects of Federal Policy, 441 ANNALs 168, 179 (1979); see also Karadbil, Housing Opportunity Plans: A Metropolitan Housing Strategy, HUD Challenge, Apr. 1977, at 22, 27 (citing seven housing programs sponsored by HUD designed to provide housing opportunities for low-income persons outside of traditional low-income areas).

1487. Mitchell \& Smith, supra note 1486 , at 175.

1488. Christensen \& Teitz, The Housing-Assistance Plan: Promise and Reality, in Housino POLICY FOR THE 1980S, at 185-98 (R. Montgomery \& D. Marshall eds. 1980).

1489. For discussion of contrary views on the benefits of greater racial integration in suburban housing versus improvement of housing in the central cities, see Phillips \& Agelasto, Housing and Central Cities: The Conservation Approach, 4 EcologY L.Q. 797 (1975). 
isolate black, low-income households in suburban neighborhoods which do not have the social services of the central city. . . . Nationally, some members of the black community [opposed] the program arguing that it is a deliberate attempt to scatter blacks among the white suburbs and dilute black political power. ${ }^{1490}$

In sum, Gautreaux produced vastly improved living conditions for more than a few black Americans in Chicago and in certain other areas as well. Further, its long-range promise, if fulfilled in the face of enormous social complexities and economic restraints, extends well beyond housing. For example, if it contributes to greater racial balance in metropolitan areas, then it carries the potential of achieving racially integrated neighborhood schools without resort to busing and the concomitant problem of white flight, thus many times multiplying its existing beneficial effect on personal liberty.

\section{Aliens}

Near the end of the nineteenth century, diverse laws began imposing serious and wide-ranging disabilities on aliens lawfully resident in the United States in virtually all jurisdictions. The bulk of these prohibitions restricted employment opportunities for all aliens or for those who had not declared an intention to become United States citizens. The scope of these restraints was extensive. In 1946 - two years before Takahashi v. Fish \& Game Commission, ${ }^{1491}$ when the Supreme Court effectively began its invalidation of almost all state discriminations against aliens, an effort that culminated with a group of rulings in the 1970 's ${ }^{1492}$ - Milton Konvitz listed about seventy different occupations that were legally closed to noncitizens in one or more states. ${ }^{1493}$ Moreover, as late as 1962, nearly one-third of the states had

1490. Fleming, Housing Discrimination: One Step Forward and Two Backward, ILLINoIS IsSUES, Sept. 1980. at $15,18$.

1491. 334 U.S. 410 (1948).

1492. In re Griffiths, 413 U.S. 717 (1973); Sugarman v. Dougall, 413 U.S. 634 (1973); Graham v. Richardson, 403 U.S. 365 (1971); see also Bernal v. Fainter, 104 S. Ct. 2312 (1984); Nyquist v. Mauclet, 432 U.S. 1 (1977); Examining Bd. of Engrs., Architects \& Surveyors v. Flores de Otero, 426 U.S. 572 (1976).

1493. M. Konvitz, The Alien and the Asiatic in AMERican Law 201-07 (1946). See also D. CARLINER, THE Rights of AliENS 205-55 (1977). Aliens were invariably denied employment in all government civil service positions and in police, fire, education and sanitation departments, and on public works projects, M. KoNvIrZ, supra, at 207. As of 1967, it was reported that 22 states had "conditions for employment on public works projects which deny or grossly restrict employment of aliens." Comment, Equal Protection \& Supremacy Clause Limitations on State Legislation Restricting Aliens, 1970 UTAF L. REV. 136, 141 n.25 [hereinafter cited as Comment, State Legislation]. All states forbade them from practicing law. M. KoNvIT, supra, at 188. In 1974, a comprehensive survey revealed essentially the same state of affairs, although some jurisdictions had relaxed the prohibtion in some instances. Knoppke-Wetzel, Employment Restrictions and the Practice of Law by Aliens in the United States and Abroad, 1974 DukE L.J. 871, 890-91. Forty-seven states prohibited aliens from being certified public accoun- 
significant statutory limitations on aliens' acquisition and retention of real property. ${ }^{1494}$ In addition, a number of state laws made many noncitizens ineligible for such benefits as public housing, state scholarship funds, criminal victim compensation, AFDC, and aid to the aged, disabled, blind and medically indigent. ${ }^{1495}$

The Burger Court's decisions $\mathbf{1 4 9 6}^{49}$ holding alienage ordinarily to be a "suspect" classification subject to "strict scrutiny" under the equal protection clause, render almost all of these restrictions invalid. ${ }^{1497}$ Just how difficult these sorts of laws have made the lives of foreigners resident in the United States is neither known or knowable. On the one hand, some data implies that several of the specific rulings of the Court involved the interests of relatively small numbers of aliens. In Graham v. Richardson, holding that state denials of welfare to aliens was unconstitutional, it was stipulated that Pennsylvania's refusal to grant public aid to noncitizens affected only sixty-five to seventy persons annually. ${ }^{1498}$ In the five years preceding the Court's invalidation of citizenship requirements for bar admission in In re Griffiths, an empirical study showed that "a total of only ten alien lawyers were admitted in the twelve states which openly admitted resident aliens into their bars under publicized liberal admission rules." ${ }^{1499}$ In Nyquist $v$. Mauclet, condemning state withholding of scholarship assistance for higher education from aliens who did not declare an intent to become citizens, it was suggested that the number of persons thereby disqualified "may be exceedingly small." 1500

tants; 39 from engaging in the manufacture or sale of liquor; 26 from being dentists; 25 from practicing medicine; 22 from being architects or pharmacists; 18 from being optometrists and teachers; 17 from being embalmers or funeral directors; 14 from being engineers, surveyors or mining employees; 12 from being registered nurses; 10 from being chiropractors, osteopaths or chiropodists; 9 from being barbers and guides; and 8 from being private detectives, vessel pilots, bank directors and realtors. M. Konvrrz, supra, at 210-11. Aliens have also been barred from such varied vocations as plumbing, peddling, hunting and fishing, driving vehicles for hire, selling insurance, and hairdressing and cosmetology. See generally id. at 210-11; Note, Constitutionality of Restrictions on Aliens' Right to Work, 57 Colum. L. REv. 1012 n.3 (1957); Rosales, Resident Aliens and the Right to Work: The Quest for Equal Protection, 2 HAST. CoNST. L.Q. 1029, 1036-38 (1975); Comment, Aliens' Right to Work: State and Federal Discrimination, 45 FORDHAM L. REV. 835, 836-37 (1977) [hereinafter cited as Comment, Right to Work].

1494. See Sullivan, Alien Land Laws: A Re-Evaluation, 36 TEMP. L.Q. 15, 21-26 (1962).

1495. See Das, Discrimination in Employment Against Aliens - The Impact of the Constitution and Federal Civil Rights Laws, 35 U. PrTT. L. Rev. 499, 501-02 (1974); Note, Residence Requirements After Shapiro v. Thompson, 70 CoLUM. L. REv. 134, 140-41 (1970).

1496. See note 1492 supra.

1497. Three exceptions involve police officers, Foley v. Connelie, 435 U.S. 291 (1978); teachers in public elementary and secondary schools, Ambach v. Norwick, 441 U.S. 68 (1979); and probation officers, Cabell v. Chavez-Salido, 454 U.S. 432 (1982).

1498. 403 U.S. 365,369 n.4 (1971).

1499. See Knoppke-Wetzel, supra note 1493, at 894.

1500. 432 U.S. 1,11 n.15 (1977). 
On the other hand, the number of people potentially prejudiced by the multitude of restrictions on the activities of noncitizens is very large - in 1973, there were over 4.1 million permanent resident aliens in the country and over a half million legally admitted nonresident aliens. ${ }^{1501}$ It has been estimated that the effect of statutes barring aliens from working in state and local government - held violative of equal protection in Sugarman v. Dougall 1502 - alone circumscribed employment "in occupations comprising three percent of the total nonagricultural labor force." 1503 In all, it appears fair to conclude that state discriminations against aliens have seriously damaged the personal liberties of some and measurably interfered with the well-being of a great many.

It is surely not true that the Justices' edicts have caused the formal repeal of every state and local regulation that falls within their rationale. Indeed, it is likely that many administrators will continue to apply such laws against aliens until instructed otherwise by the courts. Particularly in the employment area, as the massive number of operative restrictions decreases (as evidenced by the rulings of many courts that have followed the Supreme Court's lead), ${ }^{1504}$ thus reducing the number of job opportunities foreclosed to noncitizens, an alien's incentive to challenge a particular one (rather than simply to take different work) also diminishes. Furthermore, the Supreme Court's constitutional mandates operate only against the action of state and local government. Although the Justices also temporarily forbade exclusion of aliens from the federal civil service, ${ }^{1505}$ that result has been reversed by executive order. ${ }^{1506}$ There is also abundant evidence of extensive private employment discrimination against aliens. ${ }^{1507}$ This, however, demonstrates only that in substantially advancing individual rights neither the Court nor the Constitution can eradicate all perceived inequities.

\section{Gender}

The subject of gender discrimination and its amelioration prominently illustrates the complexities in isolating the Court's contribu-

1501. 1973 INS ANN. REP. 98 (table 35).

1502. 413 U.S. 634 (1973).

1503. Comment, State Legislation, supra note 1493, at 141 (footnote omitted).

1504. See cases collected in Das, supra note 1495, at 501-02; Comment, Right to Work, supra note 1493 , at 839.

1505. See Hampton v. Mow Sun Wong, 426 U.S. 88 (1976).

1506. See Exec. Order No. 11,935, 41 Fed. Reg. 37301 (1976).

1507. See, e.g., Parlin, Immigrants, Employers, and Exclusion, 14 SocIETy 23 (Sept.-Oct. 1977). 
tions in producing political and social change. ${ }^{1508}$ Nearly a decade before the Court's condemnation of most sex-based discrimination by government began in the early 1970 's, ${ }^{1509}$ Congress - catalyzed by the growing feminist movement as well as more widely based egalitarian forces in society (let loose in part, at least, by the Court itself) had, in the Equal Pay Act of 1963 and the Civil Rights Act of 1964, already moved to outlaw adverse treatment of women in the marketplace. ${ }^{1510}$ Thus, it is fair to question the extent to which the Justices' heightened scrutiny of gender discrimination under the Equal Protection Clause ${ }^{1511}$ was either necessary to, or in fact did, hasten the demise of such discrimination. Nonetheless, the huge number of sexbased rules that continued in force at the end of the 1960's - a 1972 computer list revealing nearly 900 such federal laws alone ${ }^{1512}$ which are either plainly invalid or extremely vulnerable under subsequently articulated judicial standards, strongly suggests that the Court's pronouncements have significantly accelerated the pace.

There appears to have been no systematic compilation of all state laws that classified on the basis of sex,,$^{1513}$ but data gleaned from a variety of sources dramatically portray the scope of the problem. The Court's edicts in Stanton v. Stanton ${ }^{1514}$ (invalidating a statute that required child support for males to age twenty-one but for females only to age eighteen) and Craig v. Boren ${ }^{1515}$ (rejecting a law permitting sale of near-beer to females at age eighteen but not to males until age twenty-one) directly overturned only a tiny handful of rules - Arkansas' as well as Utah's in Stanton, ${ }^{1516}$ and only Oklahoma's in Craig. However, the decisions' core rationale clearly called into question a large number of other sex-based differences - e.g., the minimum age to marry in about three-quarters of the states, the requirement of parental consent to marry in about one-quarter, the removal of infancy disability on marriage in about another one-quarter, ${ }^{1517}$ and the maxi-

1508. See notes 18-24 supra and accompanying text.

1509. See Reed v. Reed, 404 U.S. 71 (1971).

1510. See generally Ginsburg, Women, Men, and the Constitution: Key Supreme Court Rulings, in WOMEN IN THE COURTS 21, 25-26 (W. Hepperle \& L. Crites eds. 1978).

1511. See Craig v. Boren, 429 U.S. 190 (1976), and cases cited therein.

1512. Brief of Appellees at 20 n.17, Frontiero v. Richardson, 411 U.S. 677 (1973).

1513. Cf. L. KANOWITZ, WOMEN AND THE LAW: THE UNIFINISHED REVOLUTION (1969) (identifying numerous examples of sex-based discrimination in the law); J. ROBINSON, AN AMERICAN LEGal Almanac 334-36 (1978) (listing states which adopted a state ERA amendment or ratified the proposed federal constitutional amendment).

1514. 421 U.S. 7 (1975).

1515. 429 U.S. 190 (1976).

1516. 421 U.S. at 15.

1517. J. RoBinson supra note 1513, at 46-49, 111-15. 
mum age in some juvenile court laws in regard to delinquency and status offenses. ${ }^{1518}$

The Court's seminal decision in Reed v. Reed, 1519 invalidating a law preferring males to females when two persons were otherwise equally entitled to administer an estate, directly concerned only the state of Idaho - indeed, the offending statute had been repealed by the time the case was argued in the Supreme Court. The Justices' ruling in Orr v. Orr, ${ }^{1520}$ however, had greater immediate impact. Despite a marked trend to remove sexual distinctions in alimony obligations, ${ }^{1521}$ approximately one-third of the states continued to provide such maintenance solely for divorced wives prior to that decision. ${ }^{1522}$ Moreover, even Orr's narrow reasoning plainly endangers a host of analogous regulations. 1523

The Justices' responses to sex-based classifications in the Social Security Act - governing benefits for elderly surviving and divorced spouses $^{1524}$ — has also had great impact. After Weinberger v. Wiesenfeld ${ }^{1525}$ held that the Act's provision of payments to the wife, but not the husband, of a deceased wage earner with minor children violated equal protection, over 4,700 widowed fathers were awarded sums totaling almost $\$ 500,000$ per month. ${ }^{1526}$ Much greater assistance -

1518. S. Fox, The Law of Juvenile Courts in a Nutshell 34-35 (1984).

1519. 404 U.S. 71 (1971).

1520. 440 U.S. 268 (1979). (1977).

1521. Freed \& Foster, Divorce in the Fifty States: An Outline, 11 FAM. L.Q. 297, 309-10

1522. Comment, Male Alimony in Light of the Sex Discrimination Decisons of the Supreme Court, 6 CuM. L. Rev. 589, 591 n.23 (1976).

1523. For example, as of 1978 , two-thirds of the states imposed spousal support obligations on husbands only. J. RoBINSON, supra note 1513 , at 5 . Nearly one-half the states continued to place the primary duty of child support on the father. Id. at 5. In respect to inheritance, eight states had sex-based distinctions for devolution of real property from a deceased spouse. Id. at 107-10. Five states had distinctions for the spouse's right of election under a will. Id. at 139-45. As for divorce, many more states permitted a wife to dissolve her marriage for her husband's nonsupport than allowed a husband to do so for his wife's similar failure. Cook, "Why Can't a Woman Be More Like a Man," or Vice Versa?, 35 ALA. LAw. 409, 416 (1974). On related issues, several states afforded a homicide defense to a husband who had killed his wife's lover on discovering the two engaged in sexual conduct but none gave a wife a similar justification. See L. KANOWITZ, supra note 1513 , at 92 . Only a minority of states granted wives actions for loss of consortium. See Cook, supra, at 414-15. About $10 \%$ of the states required judicial approval before a married woman could open her own business, see L. KANOWITZ, supra note 1513, at 5657; a few states forbade wives to change their names without their husbands' consent, id. at 4344; and many states provided that a wife's domicile followed that of her husband, $i d$. at 47 . The vulnerability of all these regulations is confirmed by the Court's unanimous and quite effortless rejection of the rule in about five states, see Cook, supra, at 416, granting husbands exclusive control over the disposition of community property. See Kirschberg v. Feenstra, 450 U.S. 455 (1981).

1524. See Martin, Social Security Benefits for Spouses, 63 CoRNell L. Rev. 789, 809 (1978). 1525. 420 U.S. 636 (1975).

1526. Widowed-Father Beneficiaries, Soc. SEC. BuLL., Feb. 1977, at 26. 
$\$ 3.2$ billion through $1982^{1527}$ - was estimated by the government as a result of Califano v. Goldfarb, ${ }^{1528}$ which invalidated a requirement that husbands, but not wives, must prove actual dependency on their wage earner spouses in order to obtain old-age and survivor benefits, and the series of lower federal court decisions that followed the Supreme Court's lead by rejecting additional gender distinctions in the Social Security Act. ${ }^{1529}$ In response, the Carter Administration immediately proposed legislative elimination of all sex discrimination in the social security system and a congressionally ordered study calculated that the additional benefits for approximately 2,500 men would amount to over $\$ 20$ million for the first five years. ${ }^{1530}$

After the Justices' ruling in Rostker v. Goldberg, ${ }^{1531}$ upholding draft registration for males principally on the ground that the Court owes great deference to Congress in the areas of "national defense and military affairs," 1532 it could not be said with confidence that all of the myriad military regulations that discriminated on the basis of gender were invalid. ${ }^{1533}$ As the quite narrow reach of the Rostker rationale ${ }^{1534}$ and the Court's unhesitating disapproval of an armed services provision in Frontiero v. Richardson ${ }^{1535}$ make clear, however, a great many of the military's sex-based rules were exceedingly vulnerable if not plainly violative of equal protection. Thus, the federal statute authorizing the appointment of sons (but not daughters) of certain veterans to the service academies was amended in 1975 to eliminate the gender distinction ${ }^{1536}$ and a variety of army regulations have been altered or are no longer in force. ${ }^{1537}$

Since the Court has made clear that not every gender discrimina-

1527. Staff of Subcomm. on Social Security of the House Comm. on Ways and Means, 95th Cong., 1st Sess., Background Materials for Hearings on Social Security 33 (Comm. Print 1977). 1528. 430 U.S. 199 (1977).

1529. See H. KAY, SEX-Based Discrimination 110-11 (2d ed. 1981).

1530. U.S. Dept. of Health, Educ., and Welfare, Social Security and the ChangINg Roles OF MEN AND WOMEN 129-30 (1979). For a description of a "pension effect" provision enacted by Congress to reduce this sum, see Martin, supra note 1524, at 814-15.

1531. 453 U.S. 57 (1981).

1532. 453 U.S. at 64.

1533. See generally Beans, Sex Discrimination in the Military, 67 MIL. L. REV. 19 (1975).

1534. See generally J. Choper, Y. Kamisar \& L. Tribe, The Supreme Court: TrendS AND DEVELOPMENTS 1980-1981, at 40 (1982).

1535. 411 U.S. 677 (1973).

1536. Pub. L. No. 94-106 (1975) (codified at 10 U.S.C. $\S 4342(a)(1),(b)(1)$, (c) (1982)).

1537. Examples include such sundry U.S. Army regulations as those prohibiting branch transfers for female officers, Army Reg. No. 64-100; requiring greater educational achievements for women OCS applicants, Army Reg. No. 135-100; imposing a lower age of minority for discharge of females, Army Reg. No. 635-200; authorizing the discharge of women who marry, Army Reg. No. 635-200; and allowing shorter overseas duty tours for single females, Army Reg. No. 614-30. 
tion by government is invalid, particularly those whose purpose is "redressing our society's longstanding disparate treatment of women," 1538 some regulations will likely continue in force. For example, it may be that under the Court's rationale in Michael M. v. Superior Court ${ }^{1539}-$ upholding criminal sanctions for men (but not for women) for statutory rape - the rule in almost all states making only males criminally liable for "enticement"1540 (persuading a female of tender years to elope) may survive. In all, however, most gender-based classifications will not pass constitutional muster, thus dramatically advancing the interest in sexual equality to countless numbers of men and women. It is clear that the Court has played a substantial, if not necessarily leading, role in advancing this interest.

\section{Illegitimate Children}

Beginning in 1968, the Supreme Court has held that most, although not all, government discriminations against illegitimate offspring violate equal protection. This has resulted in the removal of a host of legal disabilities that had been imposed on many children born out of wedlock, ${ }^{1541}$ of whom there were nearly 600,000 born in 1979 alone, amounting to seventeen percent of all births in the United States for that year. ${ }^{1542}$

The seminal decision in Levy v. Louisian $a^{1543}$ directly affected only two states. It invalidated Louisiana's flat prohibition against illegitimate children recovering for the wrongful death of their mother and required Georgia to delete its provision that illegitimates be dependent on their mother in order to obtain a judgment for her wrongful death. ${ }^{1544}$ The next significant ruling advancing the personal rights of illegitimate children, however, Weber v. Aetna Casualty \& Surety Co., ${ }^{1545}$ overturned a policy in force in more than twenty states ${ }^{1546}$ which excluded such children from worker's compensation benefits on

1538. Califano v. Webster, 430 U.S. 313, 317 (1977) (quoting Califano v. Goldfarb, 430 U.S. 199, 209 n.8 (1977)); see also Schlesinger v. Ballard, 419 U.S. 498 (1975); Kahn v. Shevin, 416 U.S. 351 (1974).

1539. 450 U.S. 464 (1981); see also Parham v. Hughes, 441 U.S. 347 (1979).

1540. L. KaNOWITZ, supra note 1513 , at 1 .

1541. Statutes that burden "illegitimate" children contain particularized definitions of the term that usually recognize certain criteria for "legitimacy" beyond the parents' marital status.

1542. 103 Bureau of The Census, U.S. DePT. OF Commerce, STatistical ABstract OF THE U.S. 1982-1983, at 66 (1982).

1543. 391 U.S. 68 (1968).

1544. GA. CODE ANN. § 105-1306 (1968) (amended 1971).

1545. 406 U.S. 164 (1972).

1546. See H. Krause, Illegitimacy: Law and Social. Policy 36-37 (1971). 
the death of their father. And one year later, in Gomez v. Perez, ${ }^{1547}$ the Court rejected the laws of three states depriving illegitimates of the right to be supported by their father. ${ }^{1548}$ Although none of these Supreme Court decisions specifically considered the rule in many jurisdictions that denied illegitimates recovery for their fathers' wrongful death, ${ }^{1549}$ almost all state and lower federal cases that addressed the problem thereafter (involving at least thirteen states) recognized such a right, many specifically basing their conclusion on the Levy rationale. ${ }^{1550}$ Moreover, there appears to be little question that the Justices' reasoning in these opinions also invalidates other miscellaneous disadvantages for illegitimates - such as some state pension laws that have been interpreted to omit them ${ }^{1551}$ and several state inheritance tax provisions that discriminate against them. ${ }^{1552}$

The area of greatest uncertainty concerning the constitutional permissibility of disadvantaging illegitimate offspring is intestate succession. As of 1970, Louisiana was the sole jurisdiction that refused to treat an illegitimate child as an heir of its mother, ${ }^{1553}$ but only eleven states expressly extended the right of inheritance from the mother to descendants of illegitimates. ${ }^{1554}$ It seems clear that all such statutes disfavoring illegitimates in respect to inheritance from their mothers are no longer valid. A trilogy of Supreme Court decisions on the question of inheritance from the father, 1555 however, reveals that under current doctrine at least some discriminations in this regard survive constitutional challenge. After Trimble v. Gordon, ${ }^{1556}$ a state may no longer effect such a disinheritance for all children born out of wedlock who were not legitimated by the subsequent marriage of their parents;

1547. 409 U.S. 535 (1973). The Missouri judiciary had already reversed that state's position in response to Levy. R. v. R., 431 S.W.2d 152 (Mo. 1968).

1548. See also Pickett v. Brown, 462 U.S. 1 (1983), and Mills v. Habluetzel, 456 U.S. 91 (1982), holding violative of equal protection one- and two-year state statutes of limitations for suits by illegitimate children to establish paternity in order to obtain support.

1549. See H. KRAUSE, supra note 1546, at 36; Annot., 78 A.L.R.3d 1230, 1237 (1977).

1550. See Annot, supra note 1549, at 1238-44.

1551. See generally H. KRAUSE, supra note 1546, at 37.

1552. See generally id. at 41-42. The question remains open as to whether Fiallo v. Bell, 430 U.S. 787 (1977), which upheld congressional power to disfavor illegitimates in respect to alien immigration, extends to permitting Congress to discriminate against such children regarding citizenship obtained by being born the child of an American citizen abroad. See 8 U.S.C. $\S 1409$ (a),(b) (1982).

1553. Labine v. Vincent, 401 U.S. 532, 556-57 (1971) (Brennan, J., dissenting).

1554. Casenote, Constitutional Law - Equal Protection of Illegitimate Children, 17 LOY. L. REv. 170, 173 (1970-71).

1555. Lalli v. Lalli, 439 U.S. 259 (1978); Trimble v. Gordon, 430 U.S. 762 (1977); Labine v. Vincent, 401 U.S. 532 (1971).

1556. 430 U.S. 762 (1977). 
statutes of this kind, as of 1970, existed in about one-third of the states, ${ }^{1557}$ although by the mid-1970's some had already been altered. ${ }^{1558}$ In Lalli v. Lalli, ${ }^{1559}$ however, the Court sustained a law, operative in New York and Tennessee, ${ }^{1560}$ which permitted illegitimates to inherit from their fathers only if there had been a judicial finding of paternity during the father's lifetime. Lalli apparently also gives credence to the rule in approximately a half-dozen additional states $^{1561}$ that restricts paternal inheritance to instances in which the father has in some formal way acknowledged the child as his own. Thus, although the Court has not removed all disabilities imposed on illegitimate children in succeeding to the property of their deceased fathers (or other paternal ancestors), ${ }^{1562}$ many such barriers have fallen as a result of the Justices' mandates.

The last significant area of the law that has disadvantageously classified illegitimate children concerns benefits under the Social Security Act. In Mathews v. Lucas, ${ }^{1563}$ the Court sustained a discrimination against illegitimates which required them (but not legitimate offspring) to prove their dependency on the deceased parent before they could obtain insurance payments. In Jimenez $v$. Weinberger, ${ }^{1564}$ however, the Court had held that the Act's conclusive denial of benefits to some classes of illegitimate children (but not other classes), even though they could establish that they were dependent on a disabled parent, violated equal protection. While the Jimenez ruling would not appear to involve a large number of recipients, the Court's affirmances in $D a$ vis v. Richardson ${ }^{1565}$ and Griffin v. Richardson ${ }^{1566}$ - invalidating provisions reducing (and often totally denying) death benefits to illegitimates - affected nearly 15,000 children annually ${ }^{1567}$ in amounts typically ranging from $\$ 30$ to $\$ 50$ per month. ${ }^{1568}$ Moreover,

1557. See 47 Notre Dame Law. 392, 398-99 (1971).

1558. See, e.g., Rudolph v. Rudolph, 556 S.W.2d 152 (Ky. Ct. App. 1977); HaWAII REv. STAT. § 560:2-109(2) (1976).

1559. 439 U.S. 259 (1978).

1560. See Notre Dame Law., supra note 1557, at 398-99.

1561. See id.

1562. See H. KRAUSE, supra note 1546, at 25-28; Note, Inheritance Rights of Illegitimate Children Under the Equal Protection Clause, 54 MiNN. L. REv. 1336, 1338 (1970).

1563. 427 U.S. 495 (1976).

1564. 417 U.S. 628 (1974).

1565. 342 F. Supp. 588 (D. Conn.), affd, 409 U.S. 1069 (1972).

1566. 346 F. Supp. 1226 (D. Md.), affd., 409 U.S. 1069 (1972).

1567. Jurisdictional Statement of Appellant at 7 n.10, Richardson v. Davis, 409 U.S. 1069 (1972).

1568. See, e.g., Morris v. Richardson, 346 F. Supp. 494, 497 (N.D. Ga. 1972), vacated, 409 U.S. 464 (1973). 
several other Social Security Act provisions that exclude illegitimate children as beneficiaries, also with an apparently wider ranging impact, seemingly fall within the reach of the Court's condemnatory rationale. ${ }^{1569}$

Overall, on many important fronts, the Justices have alleviated politically imposed hardships on these "hapless children" that bear no "relationship to [their] individual responsibility or wrongdoing."1570

\section{Right to Vote}

\section{Fees for Filing in Primaries}

As of the early 1970's, about three-fifths of the states required that candidates for public office pay a filing fee in order to be listed on a primary election ballot. ${ }^{1571}$ Further, even if an office seeker chose to forego the party primary, which is the predominant route to election for most positions, nearly half of this group of states also demanded payment of a fee in order to have the candidate's name appear on the general election ballot. ${ }^{1572}$ Although many of the fifty states permitted write-in candidacies for primaries and almost all states had write-in provisions for the general election, ${ }^{1573}$ since this method for winning is dubious at best, the fact was that payment of a filing fee at some stage of the process was a prerequisite for election to a majority of the public offices in the United States. ${ }^{1574}$

The size of these fees varied considerably among the states, and within individual states as to particular offices. ${ }^{1575}$ In quite a few, the amount could not exceed $\$ 100,1576$ while in others, the levy was

1569. One such provision, 42 U.S.C. $\$ 402(\mathrm{~g})(1)$ (1982) (denying mother's benefits to women who have never been married to the deceased fathers of their illegitimate children), has nonetheless been upheld by a sharply divided court. Califano v. Boles, 443 U.S. 282 (1979). Another is 42 U.S.C. $\$ 403(\mathrm{a})(3)$ (1982) (providing that if the statutory maximum for benefits to an eligible worker's family is exceeded, payments to illegitimate children are the first to be eliminated). See generally Samuel, Social Security Benefits for Illegitimate Children After Levy v. Louisiana, 19 BUF. L. REv. 289 (1970).

1570. Weber, 406 U.S. at 175-76.

1571. For slightly different tabulations, see Developments in the Law - Elections, 88 HARv. L. REv. 1111, 1144-45 (1975); Comment, The Constitutionality of Qualifying Fees for Political Candidates, 120 U. PA. L. REv. 109, 138-39 (1971); Brief for Petitioner at 19, Lubin v. Panish, 415 U.S. 709 (1974) [hereinafter cited as Brief for Petitioner].

1572. See Developments in the Law - Elections, supra note 1571, at 1144-45; Comment, supra note 1571, at 138-39.

1573. See Comment, supra note 1571 , at $138-39$.

1574. Lubin v. Panish, 415 U.S. 709, 719 n.5. See Ireland \& Ireland, The Political Arena: Revolution in the Barriers to Entry, 1970 LAw \& Soc. ORD. 213, 214 n.8.

1575. See Plaintiff's Second Amended Complaint at 23-33, Bullock v. Carter, 405 U.S. 134 (1972). Seventeen states apparently had no fees. Id.

1576. Alaska, Arkansas, Hawaii, Kentucky, Michigan $(\$ 100$ filing fee in lieu of nomination 
greater but still relatively modest. ${ }^{1577}$ In a number of states, however, the assessment was substantial - e.g., Texas (up to $15 \%$ of annual salary), New Mexico (up to 6\%), Connecticut (5\%), Florida (3\%), Virginia (2\%), California (up to $2 \%$ ), Louisiana ( $\$ 5,000$ for any office in a municipality of more than 300,000 persons, except for the Orleans Parish School Board). 1578

The Court's 1974 decision in Lubin v. Panish ${ }^{1579}$ (relying on Bullock v. Carter, ${ }^{1580}$ handed down two years earlier) removed many of these impediments to election, which realistically amounted to an exclusion for impecunious entrants. It held that "in the absence of reasonable alternative means of ballot access, a State may not, consistent with constitutional standards, require from an indigent candidate filing fees he cannot pay." 1581

There appear to be no figures revealing the extent to which these rulings have actually resulted in persons attaining public office who would otherwise have been barred from doing so, but there is at least some data showing that the decisions have had some meaning for poor persons in the political process. For example, in the first election following Lubin in California, "forty-four indigent candidates from the state's four balloted parties - the American Independent, Democratic, Peace and Freedom, and Republican - [were] certified, without having to post a filing fee."1582 Further, there is some additional evidence that indigent candidacies are not merely futile endeavors. Thus, in the 1972 Los Angeles County Primary, an indigent contestant for the Democratic congressional nomination - who obtained a place on the ballot by court order without paying the $\$ 425$ filing fee received thirty-four percent of the vote despite only $\$ 178$ campaign expenditures. ${ }^{1583}$ Similarly, in the 1970 Democratic primary in El Paso County, Texas, an impoverished contender for the post of County Commissioner - who also got on the ballot through a federal injunction without having to pay the $\$ 1425$ assessed against his two opponents - was endorsed by one of the two major local newspapers

petition - returned if candidate is nominated or places second), Missouri, Montana, New Hampshire, Pennsylvania and Wyoming. Id.

1577. Examples include Nevada (up to \$250), Maryland (up to \$290), Mississippi (up to $\$ 300$ ), and Kansas, Nebraska, North Carolina, Washington, and West Virginia (up to $1 \%$ of the annual salary for the office). Id.

1578. Id.

1579. 415 U.S. 709 (1974).

1580. 405 U.S. 134 (1972).

1581. 415 U.S. at 718.

1582. McClellan \& Anderson, Filing Fees and Poor Candidates, The Progressive, Aug. 1974 , at 10.

1583. See Brief of Petitioner, supra note 1571, at 18. 
and won close to thirty percent of the vote (nearly twice as much as the other losing candidate). ${ }^{1584}$

Finally, even if those indigents who obtain ballot positions as a result of the Court's edict fail to capture public office, they may nonetheless make valuable contributions to the political system.

Frequently they raise issues and develop policies long before established parties are prepared to act, and their presence on the general election ballot and participation in election campaigns permits voters to demonstrate support for new or unorthodox ideas. Major party nominees may respond to popular support for other candidates by reformulating their policies and programs. Thus, despite a general lack of electoral success, minor parties and independent candidates may eventually see substantial portions of their programs implemented.

[They] may also serve a legitimizing function, by providing disaffected voters with an outlet for their frustration with established parties. Without this alternative, dissatisfied voters who find themselves repeatedly confronted with unattractive policies and candidates may come to doubt the legitimacy of the entire electoral process. ${ }^{1585}$

\section{Restrictions on Crossovers}

As of the early 1970's, at least four states - Illinois, Louisiana, New Jersey and Rhode Island ${ }^{1586}$ — had statutes of the kind held invalid by the Supreme Court in Kusper v. Pontikes. ${ }^{1587}$ These provisions required that persons who wished to vote in the primary election of a political party must declare their affiliation with that party as much as one year or more before the primary. The principal impact of these laws was effectively to destroy the significance of crossover voting. This is the practice of electors ordinarily associated with one political party voting in the primary of another - often (but not always) ${ }^{1588}$ because it "presents candidates and issues more responsive to their immediate concerns and aspirations." 1589

That this phenomenon occurs on a substantial basis and produces important consequences for the democratic process has been attested to by the studies of several prominent political scientists. ${ }^{1590}$ For ex-

1584. See Brief of Appellees, Pate et al, at 10-11, Bullock v. Carter, 405 U.S. 134 (1972).

1585. Developments in the Law - Elections, supra note 1571, at 1123 (footnotes omitted).

1586. See Kusper v. Pontikes, 414 U.S. 51 (1973); Walters v. Edwards, 396 F. Supp. 808 (E.D. La. 1975); Nagler v. Stiles, 343 F. Supp. 415 (D.N.J. 1972); Yale v. Curvin, 345 F. Supp. 447 (D.R.I. 1972).

1587. 414 U.S. 51 (1973).

1588. See text following note 1600 infra.

1589. Rosario v. Rockefeller, 410 U.S. 752, 769 (1973) (Powell, J., dissenting).

1590. See, e.g., Adamany, Cross-over Voting and the Democratic Party's Reform Rules, 70 AM. Pol. SCI. Rev. 536 (1976); Ranney, Turnout and Representation in Presidential Primary Elections, 66 AM. PoL. SCI. Rev. 21, 34-36 (1972). 
ample, crossover voters comprised between a quarter and a third of the participants in Wisconsin's vigorously disputed Democratic Party presidential primaries in 1964, 1968 and 1972.1591 In the 1978 Democratic gubernatorial primary in Massachusetts, the incumbent suffered defeat despite the appearance of an easy race, seemingly because many Democrats "changed their party affiliation, at least temporarily, so as to participate in the hotly contested Republican primary" for the Senate. ${ }^{1592}$ Within weeks of the federal judiciary's condemnation of Illinois' burdensome "lock-in" feature, the favored Daley-machine candidate for governor lost in the Democratic primary, a result generally attributed to Republican crossovers who preferred the alternative Democratic contender. ${ }^{1593}$ More generally, regardless of the impact that crossovers may have on the winners of party contests, the fact is that "the primaries have effects quite distinct from allocating delegates" in that they influence the national standings of candidates, the development of party platforms, and the "wooing [of] campaign workers and financial support." 1594 Further, prohibition of an unduly long preregistration period as a condition of voting in a primary insures a fuller and more effective voice in a major step of the political process for the large number of American voters who label themselves as "independent." 1595

Although the Court's contemporaneous decision in Rosario v. Rockefeller ${ }^{1596}$ would appear to permit durational voter affiliation rules of as long as eight months, thus still allowing states realistically to frustrate most crossover voting desires ${ }^{1597}$ (which rarely mature that long before the primary), the fact is that - at least to date those states whose procrustean laws have been struck down have not responded in this way. ${ }^{1598}$

1591. See Adamany, supra note 1590 , at 538.

1592. Note, The Party Affliation Requirement, 16 NEw ENG. L. REv. 71, 71 (1980).

1593. Note, The Right to Vote and Restrictions on Crossover Primaries, 40 U. CHI. L. REV. 636, 636 (1973).

1594. Adamany, supra note 1590 , at 540.

1595. See LeBlanc \& Merrin, Independents, Issue Partnership and the Decline of Party, 7 AM. PoL. Q. 240, 244 (1979) (one-third of the electorate "independent" as of 1976).

1596. 410 U.S. 752 (1973).

1597. This would not be true if the Court's decisions in Rosario and Kusper were to be rationalized on the ground that "eight months prior to the primary election the plaintiffs in Rosario knew or ought to have realized that they would want to vote in the primary election" of a particular political party. L. Tribe, AMERICAN ConstituTional LaW 792 (1978).

1598. New Jersey and Rhode Island enacted new regulations requiring preregistration of only 50 and 90 days respectively. N.J. STAT. ANN. $§ 19: 23-45$ (West 1984); R.I. GEN. LAWS $\S 17-9-27$ (1984). Illinois rejected a four-month preregistration requirement despite the urgings of distinguished party leaders to the contrary. See Comment, Open Versus Closed Primaries: $A$ Dilemma in the Illinois Election Process, 1977 So. ILL. U. L.J. 210, $223-24$ (1977). Louisiana 
Overall, the oft-stated justification for discouraging crossover voting of inhibiting "raiding" - the "organized attempt on the part of one party to send its partisans into the primary of the other in order to foist the least attractive candidates on it"1599 - has been largely discredited. ${ }^{1600}$ On the other hand, there has been no authoritative conclusion on the extent to which individual voters may use the crossover opportunity to engage in "strategic" voting - casting their ballots for a candidate whom they have no intention of supporting in the general election. Moreover, it has been forcefully argued that extensive crossover voting threatens the role of American political parties in minimizing the divisiveness inherent in one-issue factionalism and molding pluralities of interests into the durable coalitions needed for both societal and governmental stability. ${ }^{1601}$ Wholly apart from any evaluation of the large and imponderable issues of fact and policy comprehended by these issues, however, it in no way refutes the significance for individual rights described above of the Court's mandate in Kusper.

\section{POSTSCRIPT}

All the decisions chosen for discussion in this Article have been the product of the United States Supreme Court and almost all have involved statutes or other government regulations that dealt with specific conduct and that existed on a relatively broad scale (either nationally or at least in several states). It should be emphasized, however, that this by no means exhausts the Justices' achievements for personal liberty.

For example, in a series of rulings in the 1960's, the Warren Court upheld the right to free expression of various political dissidents and members of minority racial groups. ${ }^{1602}$ These decisions have not been made the subject of study herein because they usually concerned only trifling segments of the populace whose discrete activities were subject to general prohibitions. It is fair, though, to speculate that their cumulative force has retarded further popular repression of advocacy

went even beyond the spirit of the Justices' ruling by authorizing unlimited crossing over. LA. REV. STAT. ANN. II $\S 18: 521$ (West 1984).

1599. Adamany, supra note 1590 , at 538 .

1600. See Ranney, supra note 1590 , at $35-36$.

1601. See Note, supra note 1593, at 654-57; see also Adamany, supra note 1590, at 536.

1602. See, e.g., Brandenburg v. Ohio, 395 U.S. 444 (1969); Watts v. United States, 394 U.S. 705 (1969); Street v. New York, 394 U.S. 576 (1969); Shuttlesworth v. City of Birmingham, 394 U.S. 147 (1969); Gregory v. City of Chicago, 394 U.S. 111 (1969); Tinker v. Des Moines Indep. Community School Dist., 393 U.S. 503 (1969); Bond v. Floyd, 385 U.S. 116 (1966); Brown v. Louisiana, 383 U.S. 131 (1966); Cox v. Louisiana, 379 U.S. 536 (1965); Edwards v. South Carolina, 372 U.S. 229 (1963). 
critical of official policy. Thus, it has been urged that "tolerance for dissent over the war in Vietnam was in large measure a product of the Supreme Court's decisions in the area of freedom of speech." 1603 Such large judgments are extremely difficult to substantiate, but there is less doubt that the Justices' approval, in over ninety percent of the cases during the period before the Civil Rights Act of 1964,1604 of the first amendment claims of demonstrators seeking integration of public accommodations contributed signifcantly to their ultimate legislative victory. ${ }^{1605}$

Moreover, the fact that an invalidated rule was the law in only one state does not necessarily demean either the quantitative or qualitative significance of the Court's judgment for individual rights. For one thing, the actual number of people directly and meaningfully affected may still be quite substantial. ${ }^{1606}$ For another, in many instances, there is strong reason to believe that if the Justices were to have upheld the regulation in the single state where it was in effect, other jurisdictions would soon have promulgated their own versions of the liberty-denying prohibition. ${ }^{1607}$

Finally, both the lower federal courts and state tribunals have seized principles first articulated by the Supreme Court in confined factual settings and applied them elsewhere, often quite aggressively. This may take the form of extensions of the Justices' precepts to analogous situations a step or so beyond their origins, ${ }^{1608}$ of federal courts charting territory largely undirected by specific Supreme Court prece-

1603. S. WASBY, supra note 18, at 234.

1604. See Grossman, A Model for Judicial Policy Analysis, in FrontiERS OF Judicial RESEARCH 446-49 (J. Grossman \& T. Tanenhaus eds. 1969).

1605. See generally J. Casper, The.Politics of Civil Liberties 183-84 (1972).

1606. Thus, New York appeared to be the only state that prohibited anyone other than a physician from distributing contraceptives to minors under the age of 16 when the practice was invalidated in Carey v. Population Servs. Intl., 431 U.S. 678 (1977). Brief of Planned Parenthood Fedn. of America, Inc., et al, as Amici Curiae at 13-14, Carey v. Population Servs. Intl., 431 U.S. 678 (1977). The conclusion of several contemporary studies of teenage sexuality "that a large number of young teenagers appreciate the serious consequences of out-of-wedlock birth and would and do use contraception if and when it is available," Brief of ACLU as Amicus Curiae at 15, Carey (footnote omitted), was confirmed by comparative statistics from New York before and after the judicial action. These showed that from 1971 to 1974 - the period between the statute's enactment and its condemnation by a three-judge federal court, Population Servs. Intl. v. Wilson, 398 F. Supp. 321 (S.D.N.Y. 1975), affd. sub nom. Carey v. Population Servs. Intl., 431 U.S. 678 (1977) - pregnancy among 13- to 15-year-old girls in New York increased dramatically, Brief for Planned Parenthood at 13-14, and then dropped markedly, Communication from N.Y. State Dept. of Health, Bureau of Family Planning, to author. See also text at notes 949-51 supra.

1607. See, e.g., note 29 supra and text at notes 1283-85, 1298-99, 1378-82 supra.

1608. See, e.g., the collection of state and lower federal court decisions listed in Lassiter $v$. Department of Social Servs., 452 U.S. 18, 30 \& n.6 (1981) (extending the unqualified right to appointed counsel from most criminal prosecutions to parental termination proceedings and child-dependency and child-neglect hearings). 
dents, ${ }^{1609}$ or of state courts - both recently and historically ${ }^{1610}$ interpreting their own constitutions more sympathetically to claims of individual rights than have the Justices construing the national charter. ${ }^{1611}$

1609. See, eg., text at notes 1047-51 supra. For a brief, but revealing description of the powerful radiations for mental patients and prisoners of the landmark "institutional reform" decisions of Wyatt v. Stickney, 325 F. Supp. 781 (M.D. Ala. 1971), affd. sub nom. Wyatt v. Aderholt, 403 F.2d 1305 (5th Cir. 1974), and Pugh v. Locke, 406 F. Supp. 318 (M.D. Ala. 1976), affd. sub nom. Newman v. Alabama, 559 F.2d 283 (5th Cir. 1977), see M. PERRY, THE CoNSTiTUTION, THE COURTS, AND HUMAN RIGHTS 155-58 (1982).

1610. See Hetherington, State Economic Regulation and Substantive Due Process of Law, 53 Nw. U. L. REv. 226 (1958); Paulsen, The Persistence of Substantive Due Process in the States, 34 MINN. L. REV. 91 (1950).

1611. See, e.g., People v. Disbrow, 16 Cal. 3d 101, 545 P.2d 272, 127 Cal. Rptr. 360 (1976); State v. Opperman, 247 N.W.2d 673 (S.D. 1976); text at note 1446 supra. See generally Howard, State Courts and Constitutional Rights in the Day of the Burger Court, 62 VA. L. REv. 873 (1976); Note, Of Laboratories and Liberties: State Court Protection of Political and Civil Rights, 10 GA. L. REV. 533 (1976). 